Министерство сельского хозяйства Российской Федерации

Министерство науки и высшего образования Российской Федерации Приморская государственная сельскохозяйственная академия Дальневосточный федеральный университет Школа педагогики (Филиал в г. Уссурийске)

А.С. Коляда, Д.А. Ключников, А.Н. Белов

\title{
УДИВИТЕЛЬНЫЕ РАСТЕНИЯ ПРИМОРСКОГО КРАЯ
}

\author{
Монография
}

Владивосток

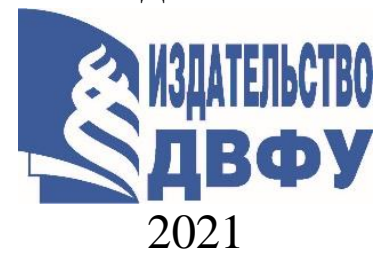

(C) Коляда А.С., Ключников Д.А., Белов А.Н., 2021

(С) Оформление. ФГАОУ ВО ДВФУ, 2021 
Рецензенты:

O.B. Храпко, д-р биол. наук, доцент, ст. науч. сотр.

Ботанического сада-института ДВО РАН;

Н.Г. Розломий, канд. биол. наук, доц. Института лесного

и лесопаркового хозяйства Приморской государственной

сельскохозяйственной академии

Удивительные растения Приморского края : монография / А.С. Коляда, Д.А. Ключников, А.Н. Белов. - Владивосток : Изд-во Дальневост. федерал. унта, 2021. - 1 CD-ROM ; [136 c.]. - Загл. с титул. экр. - ISBN 978-5-7444-4987-2. DOI : https://doi.org/10.24866/7444-4987-2. - Текст. Изображения : электронные.

Монография посвящена сосудистым растениям Приморского края. Рассматриваются особенности их строения, химического состава, распространения, а также типы взаимоотношений растений между собой и другими живыми организмами.

Работа предназначена учащимся учебных заведений, учителям и всем интересующимся растительным миром Приморья.

\section{Текстовое электронное издание}

Минимальные системные требования:

процессор с частотой 1,3 ГГц (Intel, AMD); оперативная память 256 МБ, свободное место на винчестере 335 МБ; Windows (XP; Vista; 7 и т.п.)

Программное обеспечение:

Acrobat Reader, Foxit Reader либо любой другой их аналог

Дальневосточный федеральный университет

690922, Приморский край, г. Владивосток, о. Русский, п. Аякс, 10

Тел./факс: (423) 226-54-43

E-mail:dvfutip@yandex.ru, prudkoglyad.sa@dvfu.ru

Изготовитель CD-ROM:

Дальневосточный федеральный университет, 690922, Приморский край, г. Владивосток, о. Русский, п. Аякс, 10.

Подписано к использованию 18.03.2021 г.

Объем 22,40 Мб.

Тираж 50 экз.

(C) Коляда А.С., Ключников Д.А., Белов А.Н., 2021

(С Оформление. ФГАОУ ВО ДВФУ, 2021 


\section{Содержание}

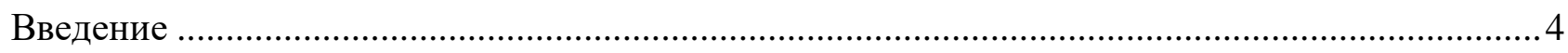

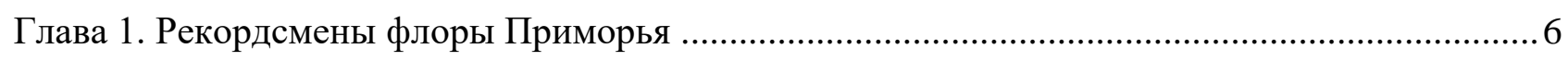

Глава 2. Растения, приковывающие взгляд ..................................................................... 27

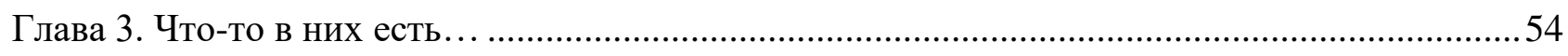

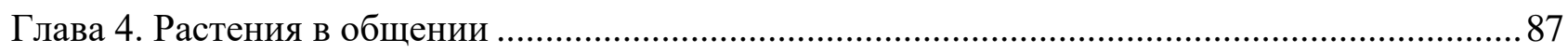

Глава 5. Расселение и распространение растений ................................................................. 105

Используемая и рекомендуемая литература …................................................................... 132

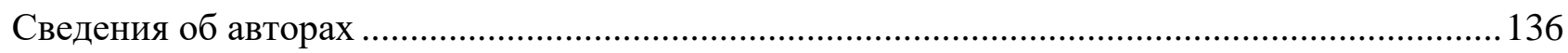




\section{Введение}

Флора - так учёные называют совокупность видов растений какой-либо территории. Часто это слово применяют и по отношению ко всему растительному миру нашей планеты. Произошло оно от имени римской богини цветов и юности. В Древнем Риме существовали праздники, посвященные этой богине, которые назывались Флоралиями. На них было принято ярко наряжаться и украшать себя цветами.

Флора Приморского края удивительно разнообразна и в настоящее время насчитывает более 2,7 тысяч из 875 родов и 173 семейств (Кожевников, Кожевникова, 2014; Kozhevnikov et al., 2019). Это составляет более чем половину от всего количества сосудистых растений, произрастающих на российском Дальнем Востоке. При этом почти 560 видов встречаются только на территории Приморья. Нередко у нас можно встретить, подчас в одном и том же месте, растения, обычные для севера, и теплолюбивые южные виды, обитающие в тропиках и субтропиках.

Если сравнить число видов сосудистых растений в каждом отделе (отдел - одна из самых крупных единиц в систематике растений) в Приморском крае и на Дальнем Востоке России, окажется, что, например, плаунов в Приморье насчитывается 16 видов (из 25 дальневосточных), хвощей 7 видов (из 8 на Дальнем Востоке), довольно много папоротников 64 вида из 98, произрастающих в Дальневосточном регионе. Голосеменные в Приморье представлены 17 видами из 22 дальневосточных. Преобладают в нашем крае, конечно, цветковые растения - более двух тысяч видов, примерно половина от дальневосточных представителей этого отдела растений.

Виды живых организмов систематиками складываются в роды. Число родов во флоре Приморья превышает 700. Если разделить общее количество видов на число родов, то получится, что каждый род составляют около 3 видов. На самом деле, конечно, распределение видов по родам весьма неравномерно. Среди них есть такие, которые включают в себя только один вид (они называются монотипными). Их немного - сусак, линнея, шейхцерия, гидрилла и ряд других. Намного больше родов, которые представлены одним видом только в Приморье, но на самом деле содержат в себе до нескольких десятков видов - лимонник, кувшинка, луносемянник, барбарис и др. Наконец, в некоторых родах содержится много видов, зачастую имеющих настолько неуловимые отличия, что различить их могут лишь специалисты-ботаники. Так, в большом роде ива насчитывается несколько десятков видов, еще больше их в роде осока, который, кстати, считают одним из самых «богатых» на Земле - он включает в себя до 2000 видов (В Приморском крае - около 130 видов).

Роды составляют семейства, которых в дальневосточной флоре насчитывается более 160. Значительная их часть представлена и в Приморье. Наиболее богаты видами такие семейства, как Астровые (Сложноцветные), Мятликовые (Злаки), Осоковые, Капустовые (Крестоцветные). Самое крупное семейство планеты - Ятрышниковые (Орхидные) - включает 30 тысяч видов, но в Приморье произрастают около 40 его представителей. Астровые, которых на Земле имеется до 20 тысяч видов, в Приморье представлены примерно 270 видами, а Мятликовые - более 220 видами из 10 тысяч, произрастающих на нашей планете. Другие семейства, напротив, в Приморье бедны видами - Восковниковые, Ореховые, Пионовые, Повойничковые и др.

К настоящему времени флористический состав Приморского края изучен достаточно полно. Он отражен в многотомном справочнике «Сосудистые растения советского Дальнего Востока» (Сосудистые..., 1985-1996; Флора..., 2006) и в других публикациях (Любарский и 
др., 1961; Заиконникова, 1966; Гурьев, 1980; Дикорастущие..., 1982; Манько, 1987; Панков, 1987; Петухова, 2006; Гуков, 2009; Храпко и др., 2012; Урусов, Лобанова, 2018 и др.). Много работ посвящено арборифлоре Приморья (Овсянников, 1931; Строгий, 1934; Цымек, 1956; Воробьев, 1968; Недолужко, 1995; Урусов, 1995, 1999; Денисов, 2003; Усенко, 2009; Урусов и др., 2004), что неудивительно, учитывая большое экономическое значение древесных растений (Журавков, 1968; Шретер, 1975; Василюк и др., 1987; Прогунков, 1989, Измоденов, 2001; Денисов и др., 2005 и др.).

Имеются публикации, касающиеся отдельных систематических групп растений Приморья (Горовой, 1966; Врищ, 1972; Коркина, 1975; Миронова, 1982; Старченко, 1985; Стародубцев, 1990; Журавлев, Коляда, 1996; Кожевников, 2001; Гончарова, 2006 и др.).

Немало работ и по отдельным направлениям биохимии, биологии, экологии и экономики растений края (Куренцова, 1968; Титлянов, 1969; Супрунов и др., 1972; Буч и др., 1981; Дикорастущие..., 1982; Комарова, 1986; Небайкин, 1991; Паршина, 1995; Нечаев, 2001, 2009; Максимов и др., 2002; Орехова, 2005; Пшенникова, 2005; Нечаев, Наконечная, 2009; Комарова и др., 2012; Колдаева и др., 2013 и др.). Выявлены редкие и исчезающие (Красная книга..., 2008), адвентивные (Нечаева, 1998; Коляда, 2007) виды Приморья. Рассматриваются этимология русских названий (Гуков, 2001; Коляда и др., 2009, 2017), английские названия (Коляда, Кадис, 2011), жизненные формы растений (Безделева, Безделев, 2006).

Немногочисленны определители растений Приморского края. Ряд из них охватывает территорию Дальнего Востока в целом или нескольких регионов (Комаров, КлобуковаАлисова, 1925, 1931-1932; Воробьев, 1958; Воробьев и др., 1966; Недолужко, 1982). Имеются определители сосудистых растений юга края (Воробьев, 1982), весенних растений Приморья (Воробьев, 1949; Фролов, Коляда, 2000), сорных растений (Нечаева, 1993), древесных растений в летний (Коляда, 2008) и зимний (Коляда, 2020) периоды. Издавался и определитель растений Приморья для школьников (Нечаева, 2000).

С развитием электронных систем коммуникаций (интернета) появилась возможность более подробно познакомиться с природой Приморского края. Например, много сведений о растениях Приморья содержится на сайте Ботанического сада-института ДВО РАН (http://botsad.ru/ru/).

Настоящая работа посвящена наиболее своеобразным растениям Приморья и предназначена для студентов биологических специальностей, школьников и учителей биологии края, а также всех интересующихся его неповторимой природой. 


\section{Глава 1. Рекордсмены флоры Приморья}

Бесконечно велико флористическое разнообразие нашей планеты. И всё же, всегда можно найти растения, разительно отличающиеся от прочих и поэтому считающиеся самыми-самыми. Самыми крупными, самыми миниатюрными, самыми красивыми... Перечислять можно долго, поскольку признаков, по которым можно выделить то или иное растение из окружающих его представителей растительного мира, очень много.

Нужно признать, что наиболее впечатляющие «рекорды» ставят растения тропиков, где для их существования сложились весьма благоприятные условия. Однако и в Приморском крае можно отыскать немало «чемпионов» регионального, если можно так сказать, уровня.

\section{Гиганты и карлики}

Мифологические титаны, вымершие исполинские динозавры... Они удивляли мир своими невероятными размерами. А каких максимальных размеров способны вообще достигать живые организмы Земли? Может ли в современных условиях обычнейшая пастушья сумка, вырастающая на десяток-другой сантиметров, вымахать высотой в дом?

Ответ на этот вопрос, конечно, будет отрицательным. Размеры организмов, обитающих на нашей планете, ограничены вполне определёнными факторами. Прежде всего, они обусловлены той генетической программой, которая записана в ДНК каждого организма. Именно она обозначает те границы, в которых существует её внешнее проявление. В генетике эти границы носят название нормы реакции. Меняются условия - изменяется проявление каких-то признаков, например, размеров, но «перейти» заданные границы организм не может.

Таким образом, в пределах нормы реакции внешняя среда тоже может оказывать своё влияние на размеры организмов. Основное значение среди факторов среды имеют сила тяжести и количество доступного кислорода, необходимого для получения энергии.

В воздушной среде определяющую роль играет сила тяжести - слишком большие (a, значит, массивные) наземные организмы будут просто раздавлены своей же массой. Одни из наиболее крупных «ужасных ящеров», бронтозавры, которые достигали 18 метров длины и весили до 20 тонн, имели, по последним данным, полые кости, дабы уменьшить общую массу тела.

Кроме того, наземные организмы должны обладать совершенной системой проведения кислорода по телу (т.е. иметь развитые дыхательную и кровеносную систему). Именно поэтому, например, насекомые, трахейное дыхание которых несовершенно, не могут достигать размеров больше тридцати-девяноста сантиметров. А масса птиц не может превышать шестнадцати килограммов - ведь им нужно летать, а на полет тратится весьма значительная энергия... В то же время нелетающие пернатые могут быть гораздо тяжелее - вес африканского страуса, например, достигает 175 килограммов, а австралийского казуара - 60 килограммов.

Если среда более плотная (вода, например), воздействие силы тяжести не столь значительно, и здесь уже появляются некоторые перспективы.

Впрочем, особые условия внешней среды могут дать некоторую, иногда значительную, прибавку в росте и наземных организмов, в т.ч. растений. Связано это прежде всего с питанием. Известно, что побеги и листья порослевых экземпляров гораздо крупнее таковых 
взрослых растений - мощная корневая система материнского растения питает их так хорошо, что интенсивность роста значительно превышает норму.

Другой яркий пример - гигантизм растений Камчатки, Сахалина и Курильских островов. Здесь многие травы достигают двойных-тройных размеров по сравнению, скажем, с Приморьем. Причины этого явления еще нуждаются в окончательном выяснении, но уже сейчас ясно, что участки крупнотравья располагаются в зонах активных тектонических процессов. Здесь формируются определённые типы почв (чаще всего глеевые), по разломам земной коры к поверхности поднимается тепло недр Земли, наблюдается повышенное содержание многих микроэлементов. Иными словами, создаются весьма благоприятные условия для роста растений.

Немало крупных растений в тропиках с их высокой и практически постоянной температурой и большой влажностью воздуха.

Но... даже в идеальных условиях рамки нормы реакции не дают растениям «разгуляться» и достичь небес, как в английской сказке о волшебном бобе. И на Сахалине или Курилах травы не вырастают до десяти- или пятнадцатиметровой высоты. Изменение внешних условий позволяют лишь подойти к крайним значениям, свойственным различным признакам - причём как в сторону увеличения, так и уменьшения. Ведь если условия не улучшаются, а наоборот, становятся хуже, размеры растений, как правило, уменьшаются, и это уменьшение также не бесконечно.

Следует отметить, что, возможно, большое значение для достижения тем или иным видом определённых размеров, имеет и та роль, которую организмы выполняют в биоценозах или даже во всей биосфере.

А по какому критерию можно судить, что данный организм является самым крупным? По линейным размерам, например, длине и ширине? По занимаемому объёму? Нужно признать, что в большинстве своём эти признаки коррелируют, т.е. самый крупный организм будет, по-видимому, иметь и самый большой объём. Но это правило не абсолютно.

Как же мы поступим? Давайте примем за такой критерий протяжённость тела в любом направлении.

В таком случае среди животных самым крупным можно считать синего кита, длина которого превышает тридцать метров, а масса достигает ста двадцати тонн. Наземные гиганты, слоны, сильно ему уступают: длина их редко превышает семь, а высота - трёх-четырех метров. Да и масса, конечно, меньше - максимум пять тонн.

Что касается растений, то они дают животным большую фору. Так, некоторое время назад появилось сообщение об обнаружении в Средиземном море обширной колонии водного цветкового растения посейдонии океанической из одноименного семейства. Одна из куртин этого растения (куртина - совокупность дочерних особей, связанных с материнским посредством корней или корневищ), обнаруженная возле Ибицы, имеет площадь восемь километров! Если это сообщение подтвердится, это растение можно будет считать самым большим живым организмом на нашей планете - ведь куртина, по существу, представляет собой единый организм, и лишь после утраты связи с материнским растением (чаще всего в результате перегнивания связывающих их побегов или корней) дочерние особи становятся самостоятельными, образуется клон - совокупность дочерних особей, образованных вегетативно от материнской.

Таким образом, два представителя двух различных царств живых организмов, претендующих на максимальные размеры, оказались, как, собственно, и ожидалось, водными 
обитателями. Если же мы выберемся на сушу, то сможем зафиксировать гораздо более скромные «рекорды».

Наиболее крупным наземным растением следует, вероятно, считать фикус бенгальский (он известен также под названием «баньян») из семейства Тутовые. Зарегистрирован диаметр его кроны, ни много ни мало, - в полкилометра! Сообщалось и о более крупных экземплярах. Чтобы добиться таких впечатляющих результатов, баньяну пришлось пойти на хитрость. Дело в том, что для него весьма характерны так называемые корни-подпорки. Представьте себе: ветвь растёт, увеличивает свой диаметр, тяжелеет, и, казалось бы, вот-вот падёт под собственным весом, но... не тут-то было! На ветви образуются придаточные корни, которые растут вниз и достигают почвы, разветвляясь в ней. Постепенно надземные части этих корней утолщаются, преобразуясь в своеобразные опорные столбы, поддерживающие ветвь. Получив столь эффективную подмогу, она продолжает расти, формируя дополнительные опоры. В конечном итоге, сформировав значительное число таких корней-подпорок, одна особь может занять площадь в несколько гектаров. У одного растения на о. Шри Ланка насчитали триста пятьдесят мощных придаточных корней и более трёх тысяч мелких!

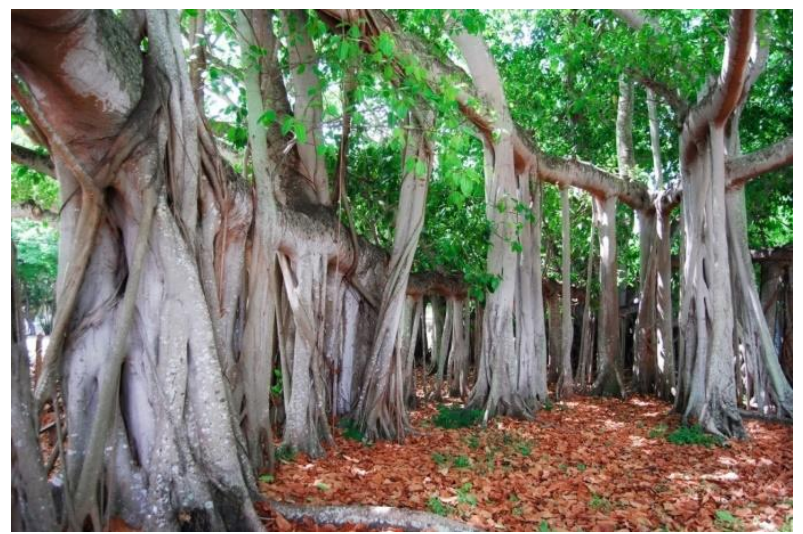

Баньян (https://c3.emosurf.com)

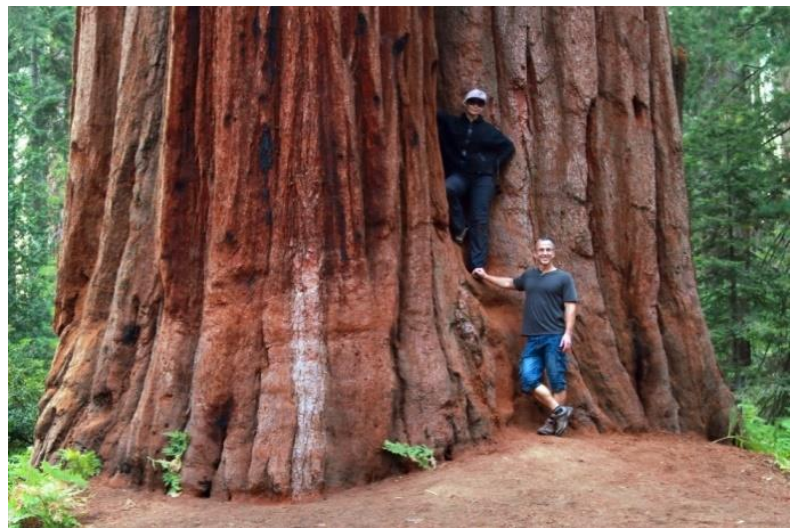

Ствол секвойи (https://cs10.pikabu.ru)

Немногим уступают баньяну лиановидные ротанговые пальмы (семейство Пальмовые), главным образом рода каламус, представители которого встречаются в тропиках Азии и Африки и достигают в длину четырёхсот метров. Да и другие лианы стараются не отставать - например, длина некоторых филодендронов из семейства Ароидные (у нас ряд видов можно встретить в комнатной культуре) доходит до двухсот-трёхсот метров. Впрочем, лианы находятся в несколько более выгодном положении - они используют для своего роста опору (чаще всего другие растения), поэтому в оптимальных условиях существования, какие сложились во влажных тропиках, и могут достигать большой протяжённости.

А вот обычным растениям, с вертикальным ростом, не позавидуешь. Основная проблема для них заключается в том, что они должны каким-то образом поглощаемую корнями из почвы воду транспортировать по своим тканям в надземные части, прежде всего в листья, из которых она испаряется. Именно транспирация (такое название носит испарение воды растениями) вынуждает воду подниматься по проводящим элементам, сосудам, вверх, поскольку в стволе растения вода образует цельный водяной столб. Если высота растения не превышает 10 метров, транспорт воды осуществляется легко. Но если растение будет еще выше, возникают сложности. Водяной столб в стволе уже не сможет сохранить целостность - под действием атмосферного давления он просто разорвётся, и 
транспорт воды прекратится. Однако многие деревья и даже некоторые травы устремляются ввысь и на бо́льшую высоту, не испытывая проблем с передачей воды к листьям. Решение этого парадокса нашли лишь в XIX веке. Оказывается, молекулы воды тесно связаны водородными связями как между собой (это явление назвали когезией), так и со стенками сосудов проводящих тканей, по которым она транспортируется. Молекул воды много, а, значит, много и этих незримых нитей. И хотя одна-единственная водородная связь достаточно слаба, их совокупность замечательно «крепит» водяной столб. Поэтому чтобы его разорвать, нужно приложить достаточно большое давление - от десятков до сотен мегапаскаль. А отсюда предельная высота, на которую может вода подняться по стволу, составляет сто тридцать - сто пятьдесят метров. Теоретически более высоких растений не должно быть (в современных условиях, конечно).

Именно таких высот и достигали обнаруженные в Австралии во второй половине XIX века эвкалипты (семейство Миртовые). Это были два гиганта, один из которых устремлялся ввысь, по тогдашним, возможно, не совсем точным оценкам, на сто сорок три, а другой - на целых сто пятьдесят метров! Правда, сегодня эти «чемпионы» уже не существуют. А вот среди ныне живущих растений с 2004 года непревзойдённым рекордсменом считалась секвойя (семейство Таксодиевые), произрастающая в национальном парке Редвуд в Калифорнии (США) и имеющая собственное «имя» - «Гигант стратосферы». Его ветви пронзают облака на высоте почти ста тринадцати метров. Однако в самое последнее время его превзошли обнаруженные в том же парке секвойи «Гиперион» (более ста пятнадцати метров) и «Гелиос» (сто четырнадцать с половиной метров). Приведем сравнение: если высоту этажа жилого дома принять за три метра, значит, Гиперион сравняется с тридцативосьмиэтажным домом! Действительно - «Гиперион», т.е., с греческого, «смотрящий свысока».

Есть в растительном мире и другие исполины. Таковы некоторые представители семейства Бобовые. Компассия малаккская, растущая в болотистых лесах Индонезии и Малайзии, достигает высоты восьмидесяти метров, а её родственник, цедрелинга цепочковидная из южной Америки - семидесяти. Североамериканский представитель хвойных растений таксодиум (болотный кипарис) из семейства Кипарисовые и некоторые пальмы (семейство Пальмовые) достигают шестидесятиметровой высоты, а пихты - пятидесяти метров.

Именно пихты, принадлежащие семейству Сосновые, являются самыми высокими деревьями в Приморском крае. В литературе встречаются сведения о достижении представителя одного из видов, пихты цельнолистной, высоты пятидесяти метров при более чем двухметровом диаметре ствола. К слову, в Приморье встречаются два вида пихты - цельнолистная и белокорая. Различить их просто - листья (хвоя) пихты цельнолистной, как можно судить по названию, цельная, заостренная и довольно жесткая. Листья же пихты белокорой на кончиках слегка раздвоены. В Приморье пихта цельнолистная произрастает на самом юге (Хасанский, Партизанский, Уссурийский районы), формируя уникальные чернопихтовошироколиственные леса, отличающиеся большим разнообразием растительного и животного мира. Пихта белокорая (кора ствола у нее светлая, в отличие от предыдущего вида, имеющего кору темной окраски и поэтому нередко называемого пихтой черной) более низкоросла, достигает тридцати-тридцати пяти метров высоты и полуметра в диаметре. Распространена она на российском Дальнем Востоке более широко и является одним из основных лесообразующих видов нашего края. Высоты тридцати-сорока метров может достигать и другой представитель хвойных - сосна корейская («кедр»). 


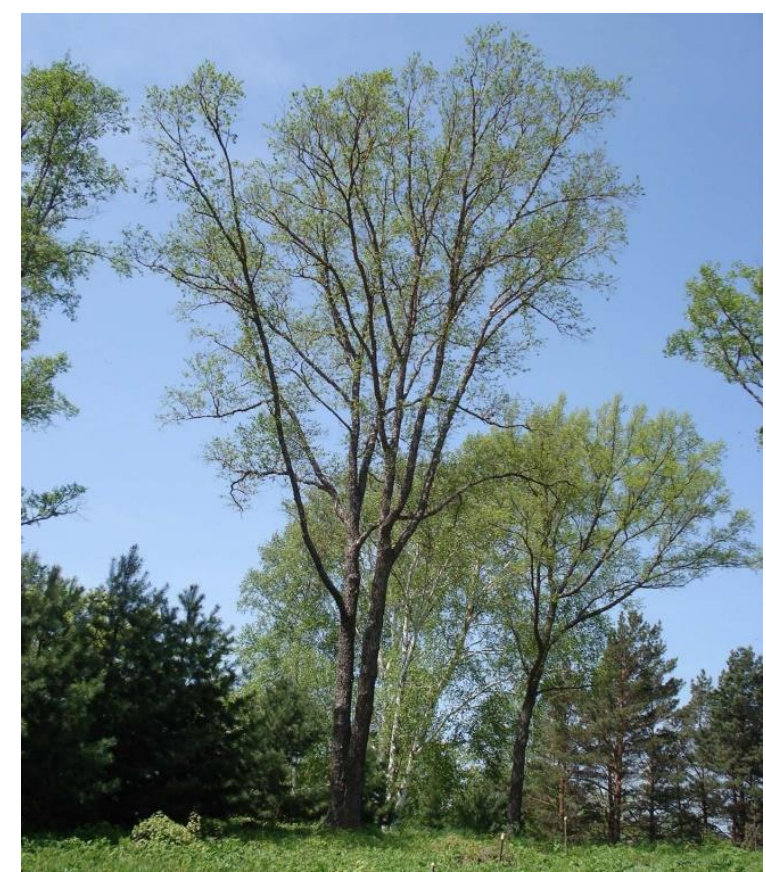

Берёза даурская

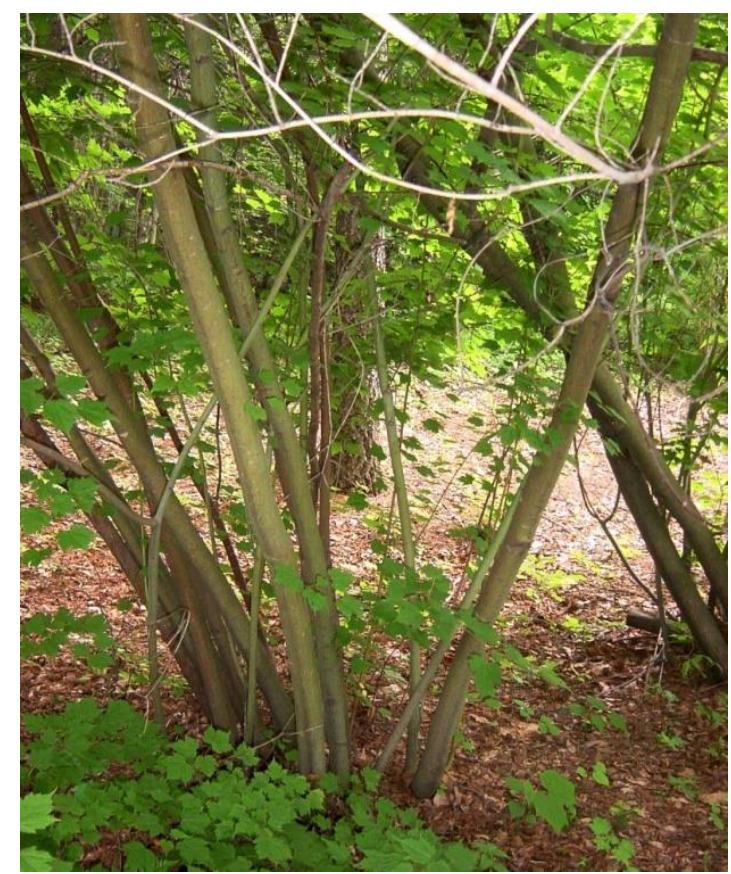

Клён бородчатонервный

Немало в Приморье лиственных древесных гигантов - дуб монгольский (семейство Буковые), ильм японский (семейство Ильмовые), липа амурская (семейство Липовые), тополь Максимовича (семейство Ивовые), ясень маньчжурский (семейство Маслиновые) и ряд других достигают 30-40-метровой высоты. К сожалению, сегодня такие экземпляры встречаются редко. Виной тому, прежде всего рубка леса, которая привела к тому, что лишь в заповедниках можно еще отыскать столь крупные деревья.

От деревьев перейдем к кустарникам. Они, как известно, отличаются от деревьев тем, что имеют несколько главных осей (стволиков), сменяющих друг друга в течение жизни растения. В Приморье кустарники преобладают среди других форм древесных растений. Среди них тоже можно выделить своих рекордсменов.

Самым крупным кустарником в Приморье является, вероятно, клён бородчатонервный из семейства Клёновые. Достигая в наиболее благоприятных условиях пятисемиметровой высоты, он имеет наиболее мощные стволики среди всех приморских кустарников - в диаметре они достигают 10-15 сантиметров. Конечно, под пологом леса, в условиях недостатка освещённости, клён бородчатонервный гораздо скромнее в своих размерах.

Другие крупные кустарники - ольховник кустарниковый (5-6 метров высоты) из семейства Берёзовые, свободноягодник сидячецветковый (семейство Аралиевые), виды бересклета (семейство Бересклетовые), калины, бузины, жимолость Маака (семейство Жимолостевые), достигающие 3-5 метров высоты.

В Приморском крае имеются чемпионы и среди трав. Это обычно растения семейств Астровые (Сложноцветные), Сельдереевые (Зонтичные) и Мятликовые (Злаки), в меньшей степени - представители других семейств. 


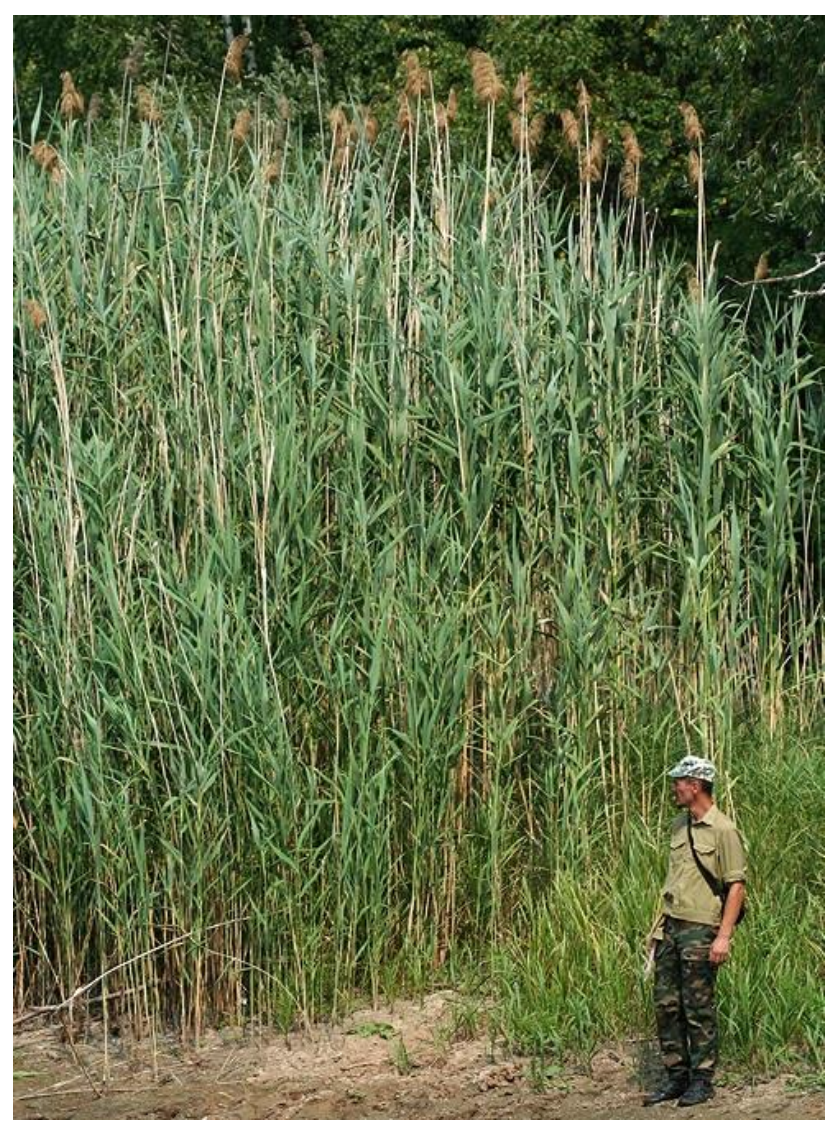

Тростник высочайший (https://www.plantarium.ru)

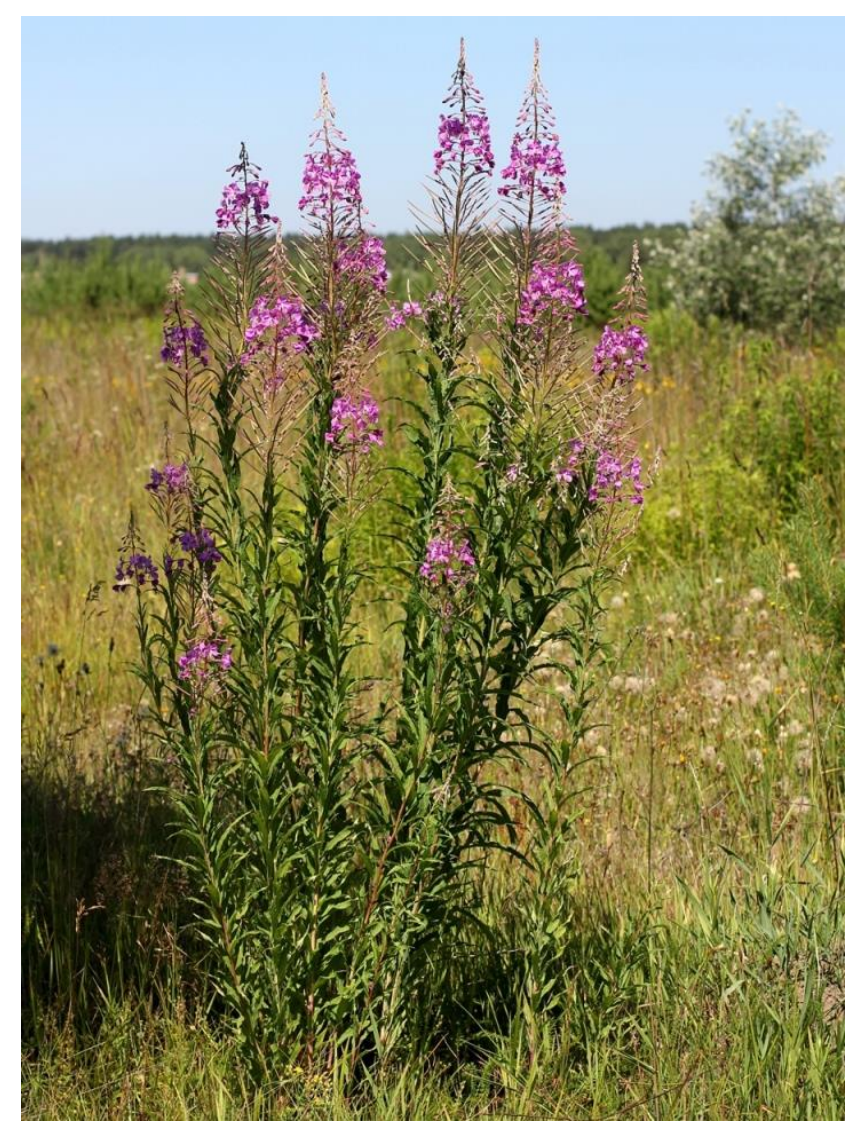

Иван-чай узколистный

(https://upload.wikimedia.org)

Вероятно, самым гигантским среди трав Приморья является тростник высочайший из семейства Мятликовые, встречающийся по берегам водоёмов на юго-западе края и достигающий пятиметровой высоты.

Среди наиболее высоких травянистых растений можно назвать достигающие трёхметровой высоты и нередко превышающие её дудник даурский (семейство Сельдереевые), произрастающий в пойменных лесах края; горец развесистый (семейство Гречиховые), который встречается по влажным местам, а также как сорное по окраинам полей, у дорог; цицанию широколистную (семейство Мятликовые), растущую по берегам озер и стариц; тростник японский (семейство Мятликовые), которого можно увидеть на приречных и приморских отмелях.

До двух - двух с половиной метров вырастают бодяк поникший, бузульник ялуский, сростнохвостник дельтовидный, какалия Чоноски, девясил высокий, циклахена дурнишниколистная (семейство Астровые), реброплодник уральский, болиголов пятнистый (семейство Сельдереевые), донник белый (семейство Бобовые), иван-чай узколистный (семейство Кипрейные), ревень обыкновенный и горец восточный (семейство Гречиховые), недотрога железконосная (семейство Бальзаминовые), чий дальневосточный, тростник южный, веероцветники китайский и сахароцветный (семейство Мятликовые), рогозы широколистный, узколистный и доминиканский (семейство Рогозовые).

Следует отметить, что и некоторые другие травянистые растения, обычная высота которых составляет 1-1,5 метров, могут в благоприятных условиях достигать больших размеров. 
К каким же хитростям прибегли травы, чтобы высокие прямостоячие стебли не гнулись и не ломались? Таких приспособлений два. Первое из них заключается в пустотелости стеблей. Такой стебель согнуть гораздо сложнее, чем заполненный тканью (или, как говорят, выполненный). Другое приспособление - образование на стебле рёбер жесткости. Это обычно тяжи механических тканей, тянущихся вдоль стебля, несколько выдающиеся над его поверхностью и формирущие при этом так называемые «рёбра». Кроме того, в узлах ребристые стебли не пустые, что повышает общую устойчивость.

Таким образом, наши травы в целом относительно невелики, хотя и среди них есть виды, достигающие значительных «высот». И все же им далеко, например, до лобелии ланурийской из семейства Колокольчиковые, произрастающей на Абиссинском нагорье на высоте двух километров и вырастающей до восьми-десяти метров. Довольно высоки гавайские колокольчиковые, например, цианея мелкочешуйчатая, достигающая двенадцатиметровой высоты. Широко известен своими гигантскими размерами банан из одноименного семейства - десять-двенадцать метров для него не редкость. Рекордсменами же среди трав, являются, безусловно, бамбуки - они достигают высоты тридцати и более метров. Однако следует отметить, что эти представители злаков были вынуждены прибегнуть к лигнификации (одревеснению) тканей, которая свойственна главным образом настоящим древесным растениям.

Следует упомянуть и о лианах Приморья. Из древесных лиан самой крупной является актинидия острая из семейства Актинидиевые. В 1964 г. заслуженный лесовод России Ю.И. Манько обнаружил на склонах хребта Восточный Синий (Чугуевский район) экземпляр актинидии острой, диаметр ствола которой на уровне почвы составлял почти 32 сантиметра. А на о. Петрова, согласно В.М. Урусову, находили экземпляры актинидии метрового (!) диаметра у поверхности почвы. В высоту актинидия острая может достигать 25 метров. Из других крупных древесных лиан можно упомянуть виноград амурский из семейства Виноградовые и кирказон маньчжурский (семейство Кирказоновые). Длина их стволов может достигать 15-20 метров.

Из травянистых лиан больших размеров достигают гумулопсис лазящий и хмель обыкновенный из семейства Коноплёвые. Хмель в Приморье является пришельцем, он культивируется в качестве декоративного растения, нередко дичая, а гумулопсис - аборигенный вид, довольно широко распространённый главным образом по открытым участкам. Стебли этих лиан достигают шестиметровой длины. Встречающийся на лугах, огородах, в кустарниковых зарослях метаплексис японский (семейство Ластовниковые) помельче - до трёх метров длины.

Следует отметить, что говоря о размерах растений, мы учитывали лишь высоту (или длину) их надземных частей. Но ведь есть еще корни! Если прибавить длину корней, размеры растений увеличатся в полтора-два раза (а у некоторых и более).

Многие растения имеют длинные корневища или корни, на которых образуются корневые или корневищные отпрыски (вспомните посейдонию). Среди наземных растений это характерно в основном для трав (пырей ползучий, например), но также и ряда деревьев и кустарников - так, у аралии высокой часто образуются корневые отпрыски, распространяющиеся на расстояние до десяти-пятнадцати метров. Общие размеры такой куртины будут довольно значительными. Куртину, как уже говорилось, можно считать единым организмом, поскольку ее составляющие генетически едины.

На очереди у нас другой полюс размерности, а именно - самые мелкие представители растительного царства. Свои чемпионы миниатюризации имеются среди всех жизненных форм растений. 
Самые маленькие древесные растения будут обитать там, где господствуют очень жёсткие внешние условия. Это прежде всего арктические районы, тундра, в том числе горная. Именно здесь больше всего карликовых деревьев и кустарников. Например, очень малы низкорослые ивы из одноименного семейства - травянистая, полярная, карликовая, высота которых варьирует от 2 до 6 сантиметров, но эти растения стелющиеся, поэтому общие размеры будут несколько больше. В дальнейшем упоминая размеры растений, мы будем учитывать высоту над поверхностью почвы у прямостоячих растений, и длину - у стелющихся.

Самым маленьким древесным растением Приморья можно, вероятно, считать произрастающую по высокогорьям диапенсию обратнояйцевидную из одноименного семейства. Этот стланичек, произрастающий в суровых условиях высокогорий, обладает и примечательной жизненной формой, являясь примером подушковидных растений (у них имеются укороченные, сильно ветвящиеся стебли). «Подушка» диапенсии небольшая, до 8 (максимум 15) сантиметров высоты.

Среди деревьев небольшую высоту имеют представители семейства Розовые абрикос сибирский (3 м высоты) и боярышники перистонадрезанный (до 5 метров высоты) и даурский (до 4 метров высоты); рододендрон Фори из семейства Вересковые, высота которого не превышает 3-5 метров; аралия высокая из семейства Аралиевые - 3-7 метров высоты. Нужно сказать, что низкорослые деревья часто принимают форму кустарника.

Среди кустарников выделяют особую группу, включающую растения, высота которых не превышает тридцати-сорока (максимум пятидесяти-шестидесяти) сантиметров. Такие растения называют кустарничками. Они населяют преимущественно высокогорья и умереннохолодные и холодные зоны, часто растут на болотах. Это, например, представители семейства Вересковые - кассиопея, подбел, шикша, зимолюбка, брусника и др. Если у кустарничков большая часть надземных побегов на зиму отмирают, их относят к группе полукустарничков. В неё входят, в частности, представители рода тимьян, высота которых в вегетирующем состоянии достигает 15-25 сантиметров. Встречаются и очень низкие тимьяны, до 2,5-10 сантиметров высоты, но они имеют стелющуюся форму роста. Еще один полукустарничек - дерен канадский (семейство Кизиловые), достигающий 15 сантиметров высоты, растёт в хвойных, реже - смешанных лесах в восточной части Приморья.

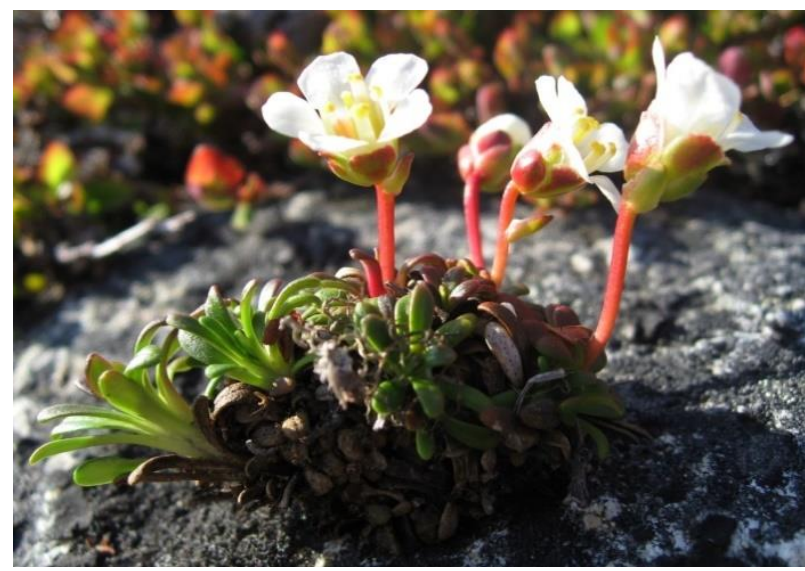

Диапенсия обратнояйцевидная (https://ru.wikipedia.org)

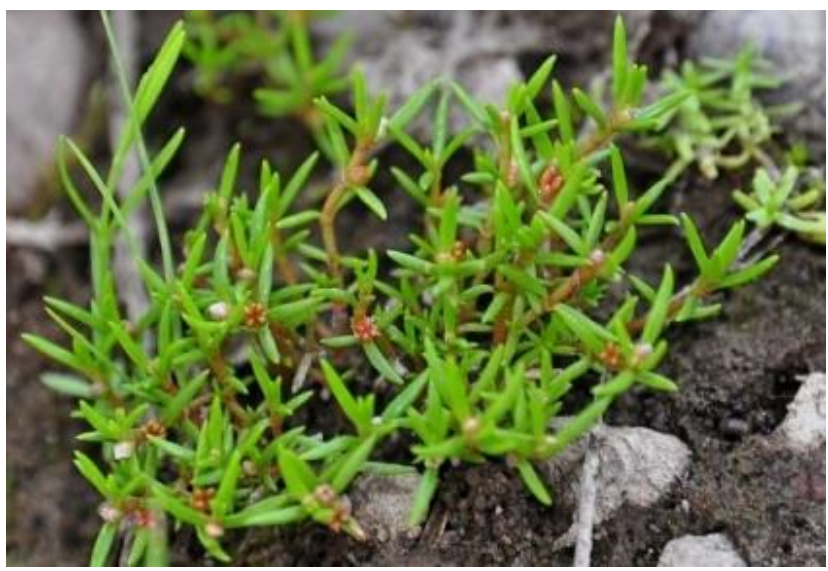

Тиллея водяная (https://i.mycdn.me) 
Из голосеменных кустарников самым маленьким, до 25-30 см высоты, является хвойник односемянный (эфедра односемянная), произрастающий по песчаным дюнам р. Киевки в Лазовском районе. Стволик растения погружен в субстрат, на поверхности заметны лишь желтовато-зелёные ветви, что делает его похожим на хвощ.

Следует отметить, что иногда человек специально уменьшает размеры древесных растений - это всем известные бонсаи. Если в природе высота растений составляет десятки метров, то в культуре - от десятка сантиметров до метра с небольшим.

Среди трав также можно найти карликов. Чаще всего (но не всегда) это также вызвано суровыми условиями существования.

Самым миниатюрным наземным растением Приморья является, вероятно, телоксис остистый из семейства Маревые, растущий по сухим склонам возвышенностей, берегам рек. Высота может составлять лишь около трёх сантиметров (в других регионах он может быть и повыше).

Не превышают десятисантиметровой высоты проломник зонтичный, низмянка мельчайшая (семейство Первоцветовые), тиллея водяная (семейство Толстянковые), болотница маленькая (семейство Сытевые), мегадения пещерная (семейство Капустовые), лужница водяная (семейство Норичниковые).

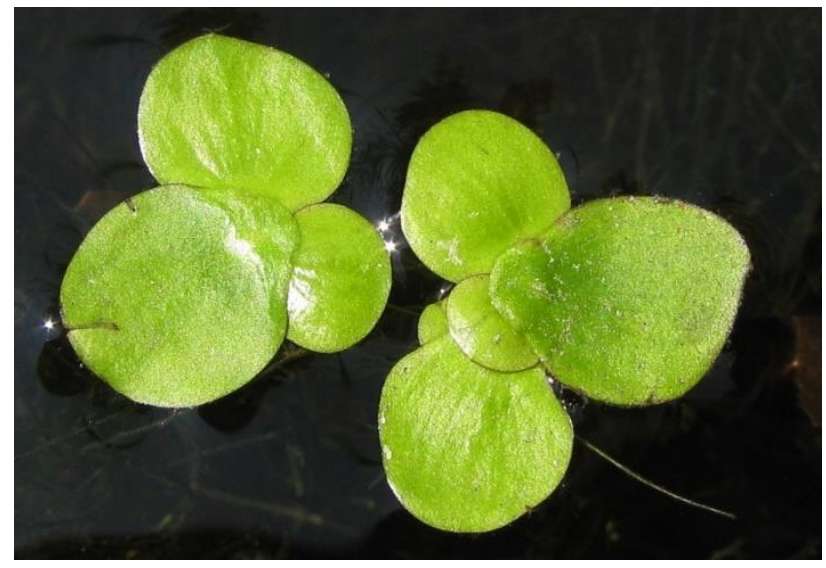

Многокоренник обыкновенный (https://www.plantarium.ru)

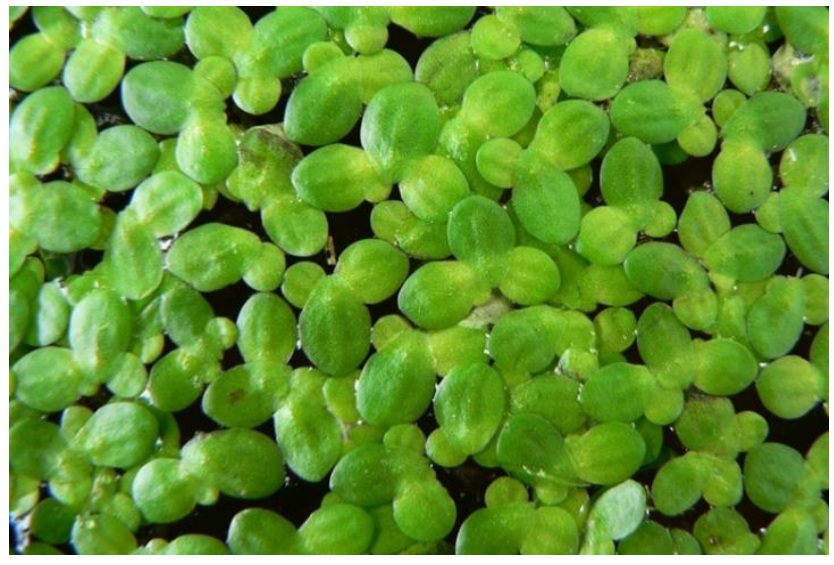

Ряска малая (https://ru.wikipedia.org)

Какие же растения является рекордсменами по миниатюрности? Получилось так, что и в этом случае первенство держат водные растения. Если исключить водоросли, среди которых есть одноклеточные организмы, это встречающиеся в озерах, старицах и на болотах представители семейства Рясковые. Всего в Приморье встречаются пять видов этого семейства - из родов многокоренник (или спиродела), ряска и трёхдольница. Это плавающие на поверхности воды или погруженные в неё (трёхдольница) растения, побег которых видоизменён в так называемый фронд, или листец. Размеры фрондов рясковых обычно не превышают одного сантиметра. Многокоренник несколько крупнее ряски, одним из видов которой является ряска малая - её размеры составляют всего лишь три-четыре миллиметра.

Однако рекорд принадлежит небольшому, примерно в семнадцать видов, роду вольфия из этого же семейства Рясковые (в Приморье его представители не произрастают). Размеры вольфии бескорневой, встречающейся в водоёмах всех материков (кроме Антарктиды, конечно), редко превышают один миллиметр. 
Итак, мы рассмотрели крайние значения размера сосудистых растений. В мировой флоре самое крупное превышает самое маленькое примерно в сто пятнадцать тысяч раз! В Приморье эта разница меньше - шестнадцать с половиной тысяч раз. Но все равно впечатляет!

\section{Листья, стебли, корни}

Наряду с целым растением разнообразие размеров свойственно и его отдельным органам.

Лист - это целая фабрика по производству органических веществ, которые образуются из углекислого газа и воды под действием солнечного света. И нередко эти «фабрики» занимают огромную площадь.

Удивительно больших размеров могут достигать листья пальм (семейство Пальмовые). Наиболее крупные из них отмечены у рафии королевской, произрастающей во влажных лесах западной Африки. Их длина может превышать двадцать пять метров. Не отстают и другие пальмы - корифа из тропической Азии, американская маникария мешкоплодная, листья длиной в десять-одиннадцать метров для них не редкость. Скромнее листья некоторых азиатских панданусов, достигающих восьми-девятиметровой длины.

Среди голосеменных первенство принадлежит вельвичии великолепной, растущей в прибрежных каменистых пустынях юго-западной Африки (главным образом в пустыне Намиб) и принадлежащей одноименному семейству Вельвичиевые. У неё имеется всего лишь два довольно широких листа, но растут они медленно, по пять-восемь сантиметров в год, стелятся по поверхности и в некоторых случаях достигают пяти метров. Другой представитель голосеменных - энцефаляртос из семейства Саговниковые, некоторые виды которого обладают шестиметровыми листьями.

Из водных растений рекордсменом является виктория амазонская - ее плавающие листья достигают двух метров в диаметре. Можно привести еще целый ряд впечатляющих примеров.

Растения Приморского края не могут похвастаться столь блестящими результатами. Однако и они при наличии благоприятных условий могут развивать листья достаточно крупных (для нашего региона) размеров.

Самые большие листья развиваются у представителей водной флоры Приморья. Если, опять же, судить по протяжённости в каком-то направлении.

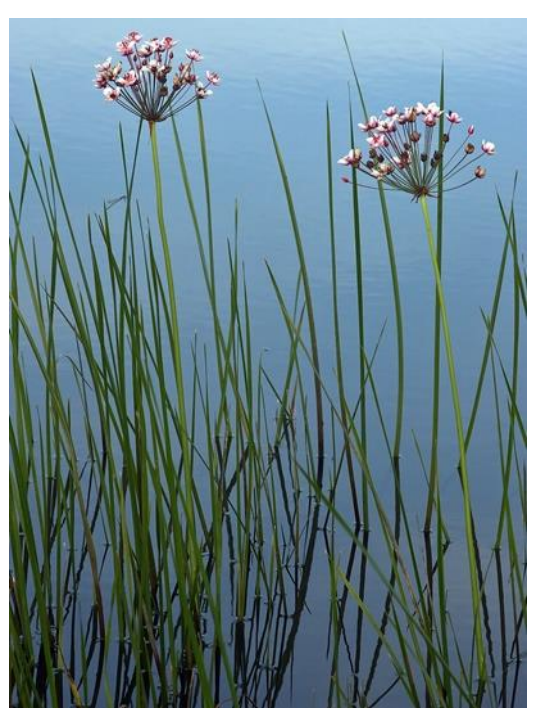

Сусак зонтичный (https://upload.wikimedia.org)

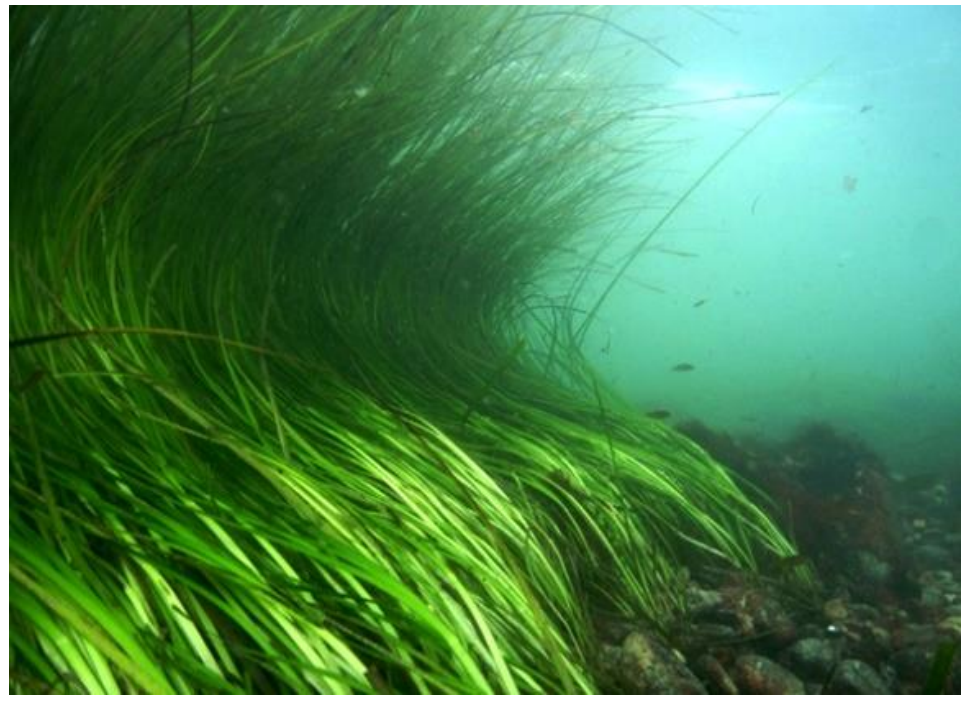

Взморник (https://lektrava.ru) 
Так, у валлиснерии азиатской из семейства Водокрасовые, произрастающей в озёрах или медленнотекущих реках бассейна оз. Ханка, листья достигают в длину двух метров. Правда, они довольно узкие - не более сантиметра ширины.

На юго-западе Приморья по берегам водоёмов и на болотах растёт сусак зонтичный из семейства Сусаковые, листья которого более метра в длину и такие же узкие.

У произрастающих близ морского побережья на глубине от 1 до 10 метров представителей родов взморник и филлоспадикс (семейство Взморниковые) листья достигают 12 метров длины, но они еще более узкие - 0,5-1 сантиметров ширины.

А вот округлые плавающие листья очень интересного растения эвриалы устрашающей из семейства Кувшинковые могут достигать 130 сантиметров в диаметре. Уступают им листья великолепного лотоса Комарова (семейство Лотосовые), диаметр листовой пластинки которого составляет чаще около 50 сантиметров, но может достигать и метровой величины.

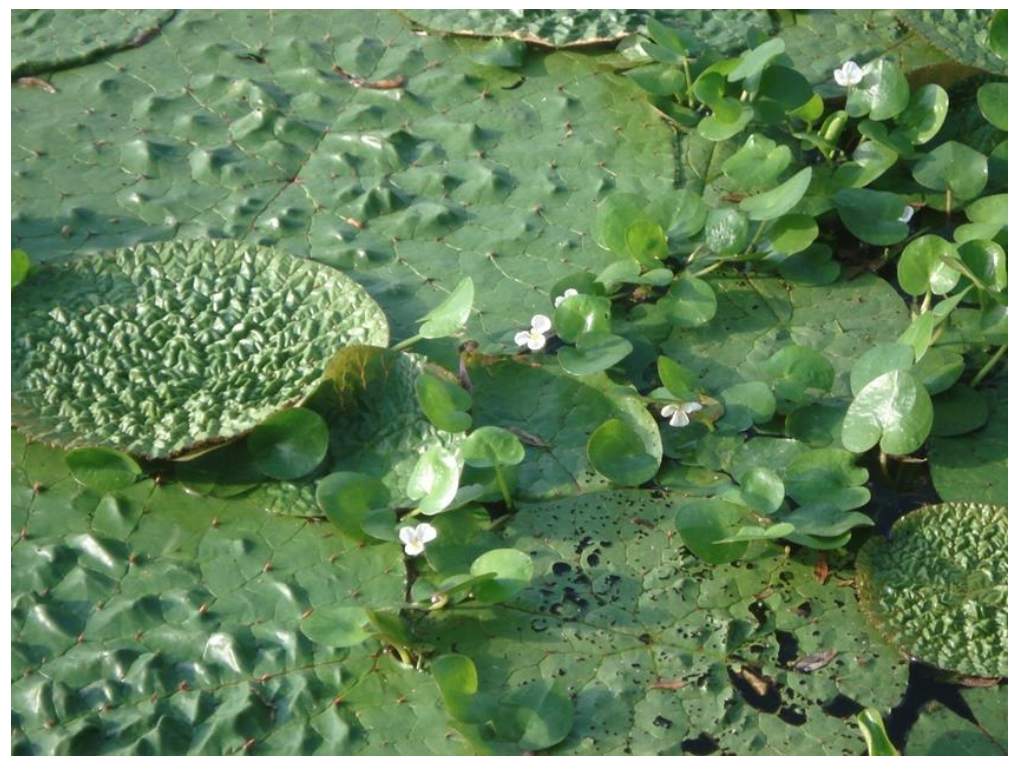

Листья эвриалы устрашающей

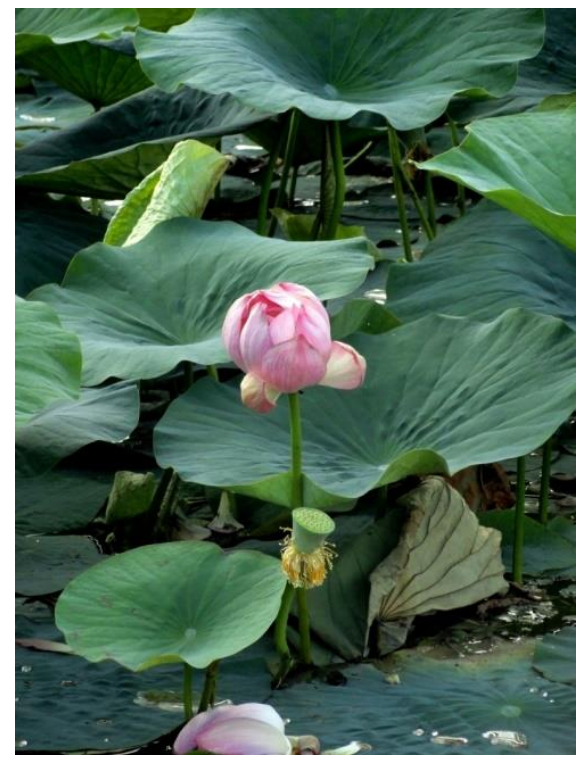

Лотос Комарова

Сухопутные растения не уступают водным.

Наиболее крупных размеров достигают сложные листья растений, листовая пластинка которых состоит из нескольких пластинок (листочков). Среди этих растений нужно сразу выделить представительницу семейства Аралиевые аралию высокую (маньчжурскую). Листья этой родственницы знаменитого женьшеня достигают полутора метров в длину (вместе с черешком) и полуметра в ширину. Этому растению свойственна замечательная особенность роста: листья взрослых растений сосредоточены на верхушке ствола, что придает деревцам пальмовидный облик.

Почти столь же крупны листья ореха маньчжурского (в длину они достигают одного метра, а в ширину - 40 сантиметров), травянистой аралии материковой (до 60 сантиметров в длину и 70 сантиметров в ширину).

Простые листья (с одной листовой пластинкой) по размерам скромнее. Явно выделяется среди растений с такими листьями лопух большой (семейство Астровые, или Сложноцветные) - у экземпляров, произрастающих в сорных местах (где, по-видимому, лучше минеральное питание), они могут достигать 1,7 метров длины и 70 сантиметров ширины. Чуть меньше листья дудников из семейства Сельдереевые - например, листья дудника даурского, 
широко распространённого в долинных лесах Приморья, достигают 150 сантиметров длины и 60 сантиметров ширины. У культивируемого ревеня обыкновенного листья в длину достигают 70 сантиметров, ширины 50 сантиметров, в то время как листья аборигенного вида, ревеня густоцветкового, произрастающего на обнажениях известняка, могут достигать 40 сантиметров длины и ширины. У представителя семейства Аралиевые заманихи высокой листья составляют 60 сантиметров в длину и 30-40 сантиметров в ширину. Крупные листья могут развиваться у дуба зубчатого, растущего на самом юге Приморья - до 40 сантиметров длины и 30 сантиметров ширины.

Составными частями листа являются листовая пластинка, черешок и основание листа. Функции черешка различны: он является опорой для листовой пластинки, а кроме того ориентирует ее в направлении световых лучей. Если черешок зелёный, значит, в его клетках имеются хлоропласты, и, следовательно, происходит фотосинтез. Наконец, через черешок проходит поток минеральных (в листовую пластинку) и органических (из неё) веществ. Основание листа часто разрастается в так называемое листовое влагалище - оно в различной степени охватывает стебель и служит дополнительной опорой листу, особенно крупному.

У растений Приморского края длинные черешки имеются у калопанакса семилопастного (до 50 сантиметров), дудника даурского (до 40 см). Любопытно, что у калопанакса семилопастного, или диморфанта, на побеге длина черешков разных листьев разная наибольшая она у листьев, находящихся в основании побега, при продвижении к его верхушке длина черешков уменьшается. Это является приспособлением для лучшего улавливания солнечного света, т.е. таким оригинальным способом создается листовая мозаика - такое расположение листовых пластинок, при котором они затеняют друг друга в минимальной степени.

Выше мы говорили об обычных стеблевых листьях. Однако у многих растений имеются так называемые прикорневые листья (отходящие от нижней части стебля, обычно находящейся в почве). Такие листья, как правило, крупнее стеблевых. Так, размеры листьев лопуха большого (репейника), приводимые ранее, относятся именно к прикорневым листьям. А длина их черешка может достигать 80 сантиметров. Почти столь же длинные черешки прикорневых листьев у подлесника красноцветкового из семейства Сельдереевые, часто встречающегося в лесах различного типа - они достигают 65 сантиметров длины.

Длинные черешки, до метра и более, развиваются у плавающих листьев водных растений - бразении Шребера (семйство Кабомбовые); кувшинок, кубышек и эвриалы устрашающей (семейство Кувшинковые); стрелолиста, водокраса и кальдезии (семейство Частуховые). И всё же они уступают уже упоминавшейся виктории амазонской, у которой фиксировались черешки 4-метровой длины.

Что можно сказать о стебле? Наверное, лишь о его толщине. В мире есть свои рекордсмены. Так, на Сицилии пять сросшихся стволов каштана посевного (семейство Буковые) вместе составляли (еще в 1875 году) 64,2 м в диаметре. А в Мексике растёт удивительный таксодиум (семейство Кипарисовые), имеющий собственное наименование (El Arbol del Tule - дерево Туле), диаметр которого равен 42 метрам. Большой диаметр ствола характерен для баобабов (семейство Мальвовые), гигантских секвой (семейство Таксодиевые).

В Приморье наибольший диаметр стебля, наблюдающийся у деревьев, составляет 1,5-2 м.

На очереди - корни растений. Их изучать сложнее, как и зафиксировать их «рекорды». А самый главный рекорд заключается в максимальной глубине, на которую они смогут проникнуть. В этом есть необходимость лишь тогда, когда недостаточно воды в виде осадков, и нужно добраться до грунтовых вод. Поэтому самые длинные корни имеют растения 
пустынь и полупустынь. Например, корни верблюжьей колючки находили на глубине 1520 метров. При бурении скважин в пустыне Калахари (Ботсвана) обнаружили корни акации на глубине примерно 45 метров.

О длине корней растений Приморья судить сложно из-за отсутствия исследований в этом направлении. Влаги в нашем крае хватает, и поэтому необходимости развивать очень длинные корни нет. Поэтому наиболее длинные корни будут наблюдаться у деревьев, они уходят на глубину в среднем на 5-7 м.

\section{Генеративные органы растений}

В процессе эволюции у растений развились особые органы, предназначенные для полового размножения. которые называют генеративными, или репродуктивными. Наиболее известными из них являются цветки (у покрытосеменных растений) и шишки (у голосеменных). Из цветков формируются плоды, содержащие семена, поэтому их тоже причисляют к генеративным органам.

Цветок - удивительное создание природы, часто оказывающее сильное эмоциональное влияние на человека. При этом спектр эмоций весьма широкий - от восхищения до неприязни.

Наибольшее восхищение вызывают не только самые красивые, но и самые крупные цветки.

Гигантские цветки у представителей царства растений развиваются у ряда видов раффлезии из одноименного семейства. Например, у раффлезии Арнольда их диаметр может превышать один метр! Рекорд в 111 см зафиксирован у раффлезии туан-мудэ, растущей в природоохранной зоне Манинджау на Суматре. Это тем более поразительно, поскольку раффлезия, как мы увидим дальше - паразитическое растение.

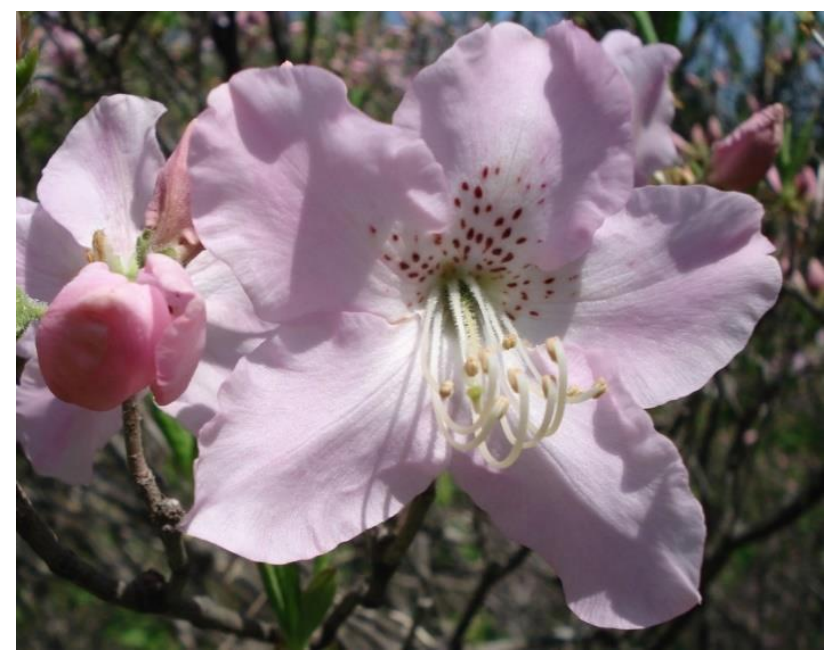

Цветок рододендрона Шлиппенбаха

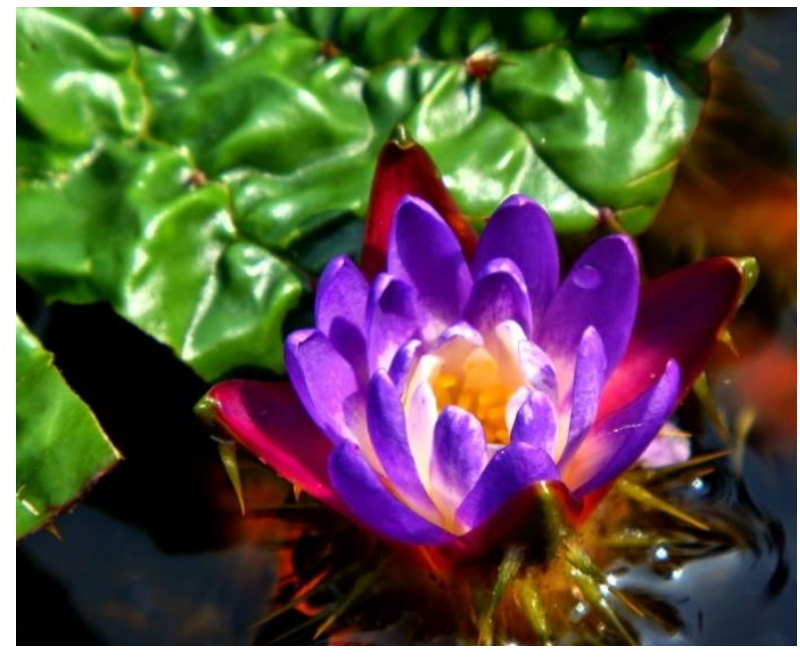

Эвриала устрашающая (https://3.bp.blogspot.com)

В Приморском крае самые крупные цветки наблюдаются у лотоса Комарова (семейство Лотосовые) - в исключительных случаях они достигают 30 см в диаметре. Цветки около 12 см в диаметре имеются у видов пиона (семейство Пионовые), таких же размеров могут достигать цветки рододендрона Шлиппенбаха (семейство Вересковые). Скромнее, 5-8 см в диа- 
метре, являются цветки кувшинки четырехгранной, эвриалы устрашающей (семейство Кувшинковые), видов шиповника (семейство Розовые), рододендрона (семейство Вересковые).

Весьма интересны цветки приморских кирказонов (семейство Кирказоновые), особенно кирказона маньчжурского. Они не столь крупны (до 6-7 см длины), но с причудливо изогнутой трубкой и трёхлопастным коричневым отгибом - и в целом похожи на маленький саксофон.

Большая часть растений Приморского края имеет цветки относительно небольшие, 1-3 см в диаметре.

Что же до минимальных размеров, то, очевидно, самый маленький цветок будет у самого маленького растения. Это уже упоминавшиеся ряска, трёхдольница и многокоренник, их цветки весьма миниатюрны - до полумиллиметра. Мелкие цветки, до 1 см в диаметре, имеются у представителей семейства Диоскореевые (диоскорея ниппонская), Яснотковые (некоторые тимьяны), Аралиевые (аралии высокая и континентальная, а также калопанакс семилопастный), Гвоздиковые (виды мшанки, песколюбочка постенная и др.).

Одиночные цветки характерны не для всех растений. У большинства они образуют группы - соцветия. Это выгодно с той точки зрения, что если погиб единственный цветок, растение уже не сможет реализовать себя в следующем поколении. В соцветии же могут погибнуть и несколько цветков, остальные все равно дадут плоды и семена.

Самое крупное соцветие в мировой флоре зарегистрировано у пуйи Раймонда из семейства Бромелиевые, произрастающей в горах Боливии. Оно достигает 12 метров в высоту и 2,5 метров в диаметре и содержит около 10 тысяч цветков! У пальмы корифы зонтичной (семейство Пальмовые) соцветие до 6 метров, но цветков в нём ещё больше. Впечатляет и соцветие аморфофаллуса титанического из семейства Ароидные - до 3 м в окружности. Для ароидных характерно соцветие початок, которое, вместе с прицветным листом (который называют также крылом), создает впечатление крупного цветка (вспомните каллу).

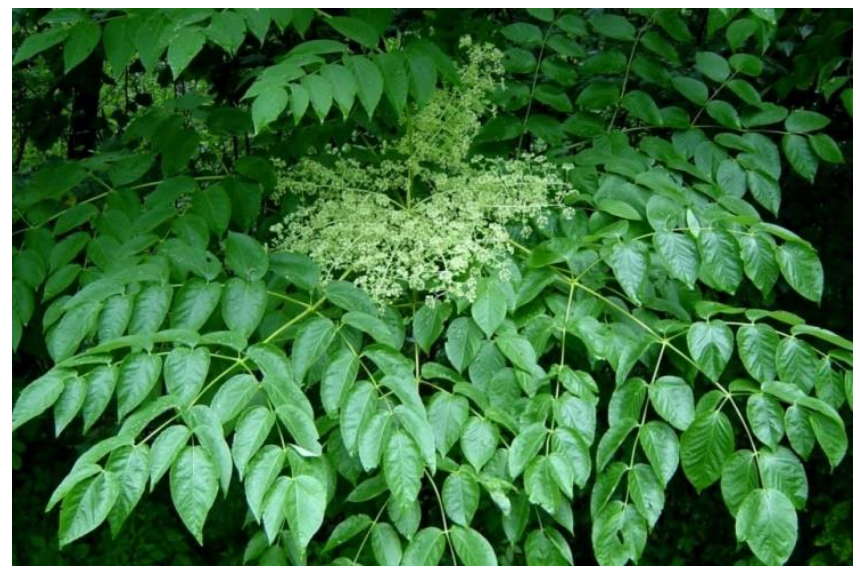

Аралия высокая

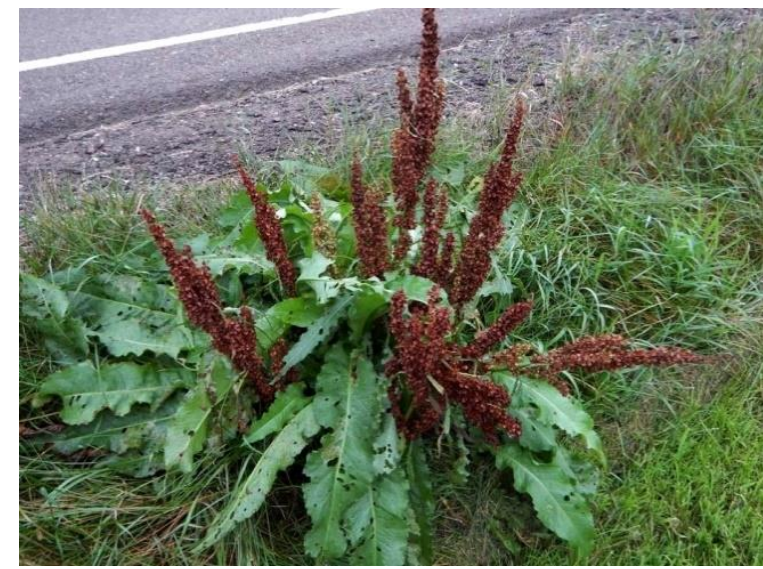

Щавель курчавый (https://herbal-grass.com)

У наших растений крупные соцветия, главным образом метельчатые имеются у видов семейств Аралиевые (аралии высокая и континентальная, чьи метёлки достигают 60 см длины, а также калопанакс семилопастный - до 30-40 см в диаметре), Гречиховые (щавели курчавый и конский, до 60 см длины), Астровые (полынь обыкновенная, до 60 см длины, полынь Гмелина, до 40 см длины), Розовые (рябинник рябинолистный, до 30 см длины), Маревые (щирица запрокинутая, до 20-30 см). 
Но вот закончилось цветение, из цветков сформировались плоды. Они тоже бывают разных размеров.

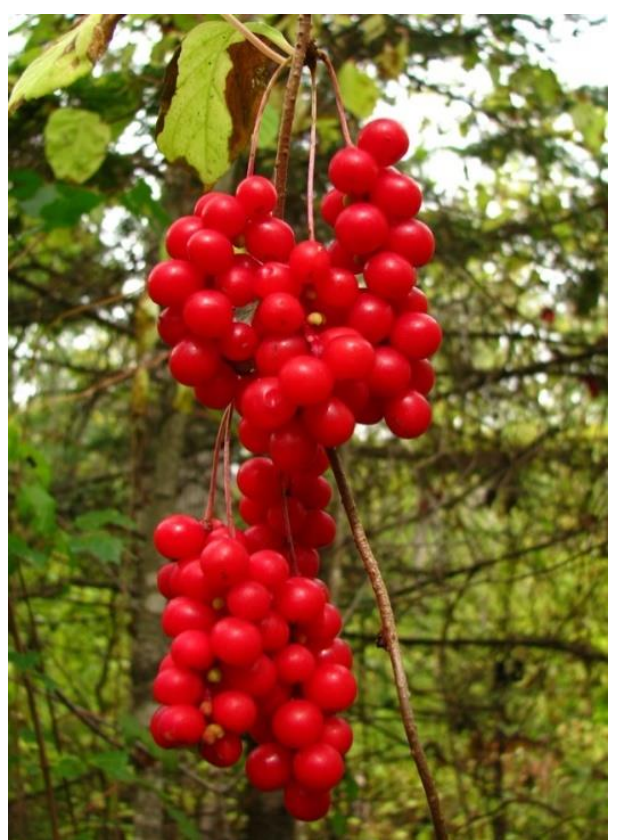

Плоды лимонника китайского

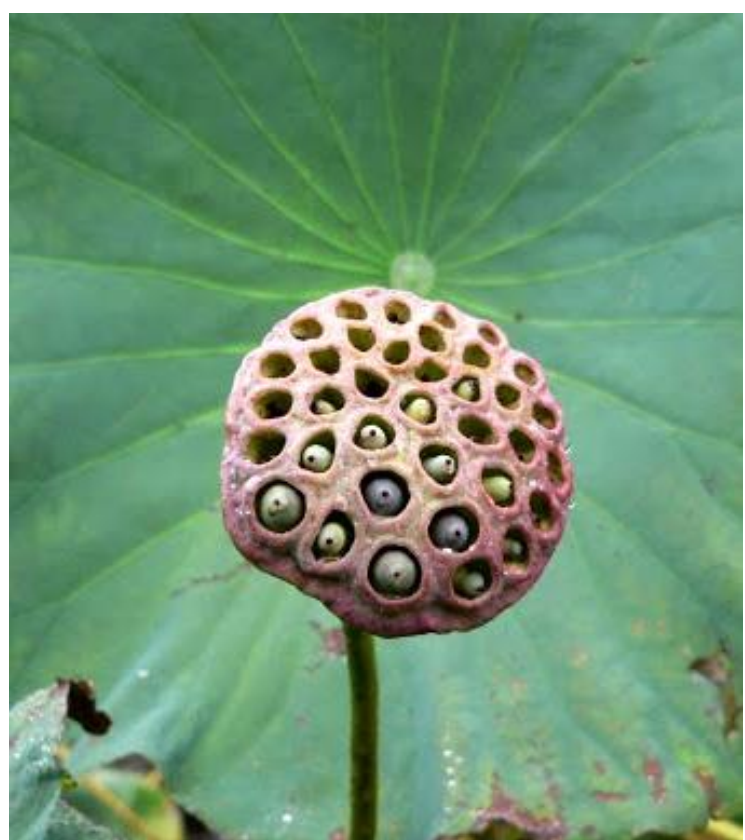

Плод лотоса Комарова (https://ru.wikipedia.org)

Наиболее крупные плоды развивает тропическое растение энтада гигантская (семейство Бобовые), произрастающее в Центральной Америке, на Карибах, в Африке. Длина её бобов достигает полутора метров. После вскрытия плода сердцевидные семена с дождем попадают в реки, а оттуда - в море, где могут путешествовать очень далеко и долго. Плод сейшельской пальмы - лодоицеи мальдивской (эндемика Сейшельских островов) достигает 50 см длины и до метра в диаметре, а вес доходит до 25 кг. Крупные плоды имеются и у других пальм.

Конечно, если человек выращивает растения, то он может создать особые условия, и получить просто гигантские плоды (в основном тыквы, арбузы, помело). Так, в 2016 г. в книгу рекордов Гиннесса попала выращенная в Бельгии тыква весом более тонны!

А вот самые крупные плоды растений Приморья не превышают 10-15 см длины.

Весьма оригинален плод лимонника китайского - известного лекарственного растения из одноимённого семейства. Осенью на лианах лимонника можно увидеть кисти с отдельными ягодовидными красными округлыми «плодами». На самом деле это не кисть вовсе, а сам плод. Называется он сочной многолистовкой. В этом плоде отдельные «ягоды», располагающиеся на сильно удлинённом цветоложе, представляют собой листовки располагающиеся далеко друг от друга и ставшие сочными. Длина такого плода может достигать 15-17 см. Нужно сказать, что у других растений Приморья с таким же типом плода (виды таволги, рябиннника из семейства Розовые, пионы из одноимённого семейства и др.) зрелые листовки сухие.

Довольно крупные плоды образуются у другой древесной лианы - кирказона маньчжурского (семейство Кирказоновые) - это шестигранная цилиндрическая коробочка до 11 см длины и 2,5 см в диаметре. 
Для лотоса Комарова (семейство Лотосовые) характерен плод многоорешек (до 10 см в диаметре), и довольно оригинальный - семена погружены в гнёзда в разросшемся цветоложе.

Стручковидные коробочки до 7-8 см длины образуются у чистотела азиатского (семейство Маковые) и поланизии двенадцатитычинковой из семейства Каперсовые. Довольно крупные, до 8 см длины, листовки развиваются у метаплексиса японского (семейство Ластовникове), растущего в поймах рек, на открытых склонах сопок.

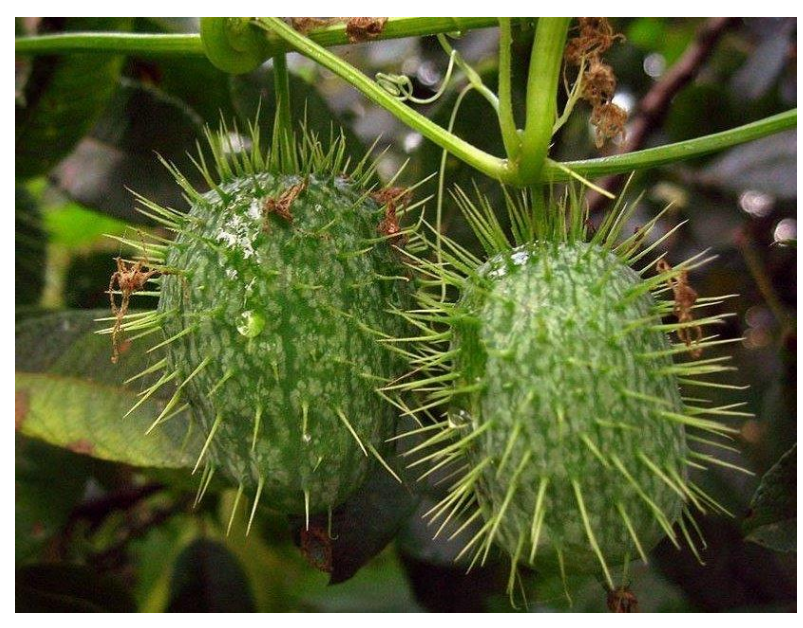

Плоды эхиноцистиса лопастного (https://zakupator.com)

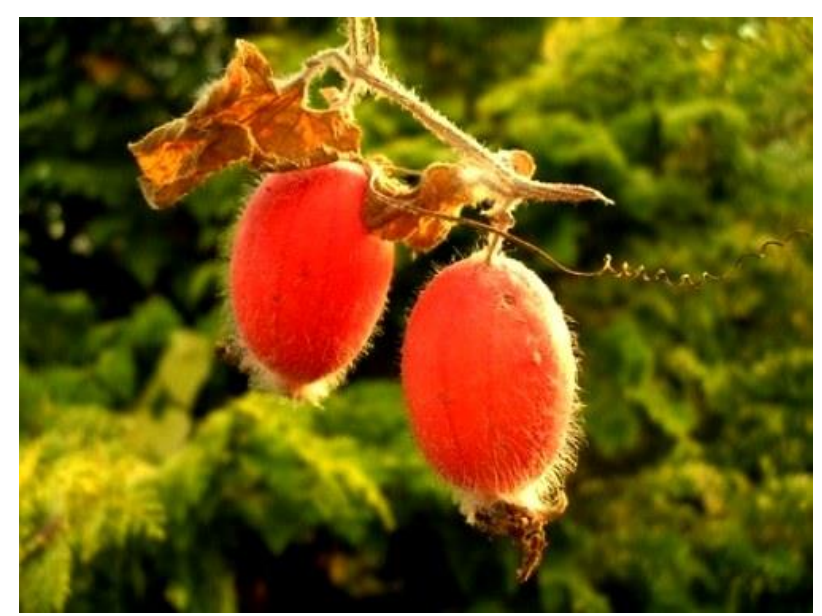

Плоды тладианты сомнительной (https://foodandhealth.ru)

У таких тыквовых, как тладианта сомнительная и эхиноцистис лопастный плоды еще меньше - до 5-6 см, у тладианты - красные, опушённые, у эхиноцистиса зелёные, шиповатые. Таких же размеров плоды у маньчжурского ореха (семейство Ореховые), груши уссурийской (семейство Розовые).

В некоторых случаях отдельные плоды срастаются настолько плотно, что соплодие выглядит как один цельный плод. Это наблюдается у всем известного ананаса (семейство Бромелиевые) или видов артокарпуса из семейства Тутовые, или Шелковицевые - так называемого хлебного дерева, соплодия которого достигают 90 сантиметров длины и 50 см в диаметре, и джекфрута, у которого продолговатые соплодия почти в метр длины.

В Приморье единственным представителем тутовых является шелковица белая, небольшое деревце до 5 м высоты. Это растение не является аборигенным, оно досталось нам «в наследство» от прежних народов, населявших край в VIII-XII веках - бохайцев, чжурчженей. И теперь спорадически встречается в местах древних поселений, а также используется в ландшафтном дизайне. Соплодия шелковицы белой небольшие, примерно 1-2 см длины. Они нередко используются в пищевых целях, обладая замечательными вкусовыми качествами. Особенно притягательно варенье из шелковицы.

Перейдём к голосеменным растениям. Самые крупные шишки имеются у представителей семейства Саговниковые. Так, у некоторых саговников шишки достигают 1 м длины и 4050 кг веса - весьма впечатляюще! У представителя родственного семейства Замиевые, энцефаляртоса кафрского, произрастающего в Капской провинции Южноафриканской Республики, шишки тоже большие, хотя и не настолько - они достигают 30 см длины и 15 см в диаметре, а массы - 40 кг. Шишки сосны Ламберта считаются самыми длинными у хвойных - до 50 см. 
В Приморье крупные шишки (женские, конечно) свойственны представителям семейства Сосновые - сосне корейской, или кедру, у которой они достигают 15 см длины, и пихтам - до 12 см. Небольшие шишки, до 1 см в диаметре, свойственны представителям семейств Кипарисовые и Тисовые. У кипарисовых - видов можжевельников - шишки до 1 см в диаметре, мясистые, поэтому часто зовутся шишкоягодами. А у тиса остроконечного женские шишки еще более оригинальны. По внешнему виду это, кажется, и не шишки вовсе, а настоящие ягоды. Семя в каждой такой шишке одно, и оно окружено красным мясистым присемянником, привлекающим распространителей - птиц. У тиса много других интересных особенностей - это единственное наше хвойное без смолы, а его листья, в отличие от других хвойных, имеют черешки. Самые маленькие женские шишки свойственны микробиоте перекрёстнопарной (семейство Кипарисовые) и хвойнику односемянному (семейство Хвойниковые), они до 6-8 мм в диаметре, односемянные, у микробиоты - сухие, буроватые, у хвойника - ягодообразные, красные.

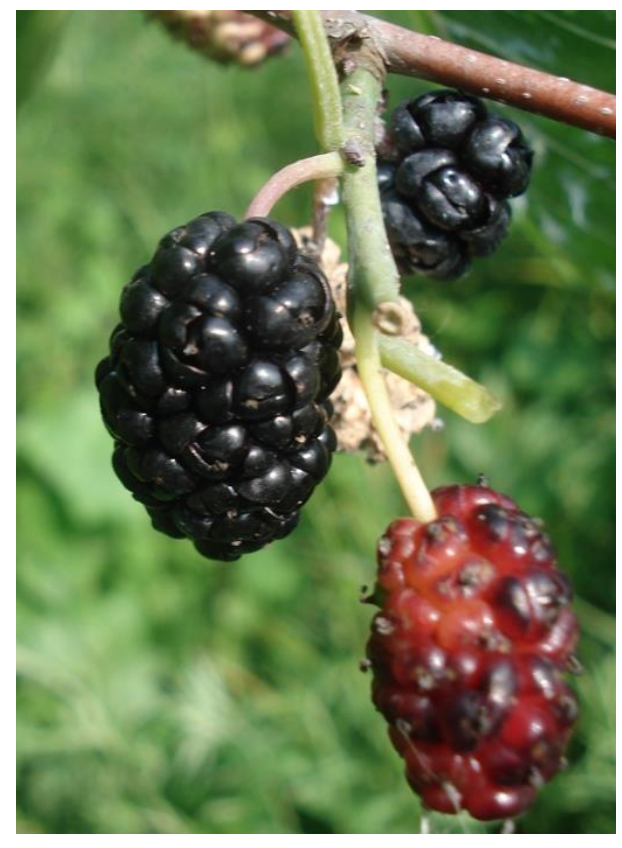

Соплодия шелковицы белой

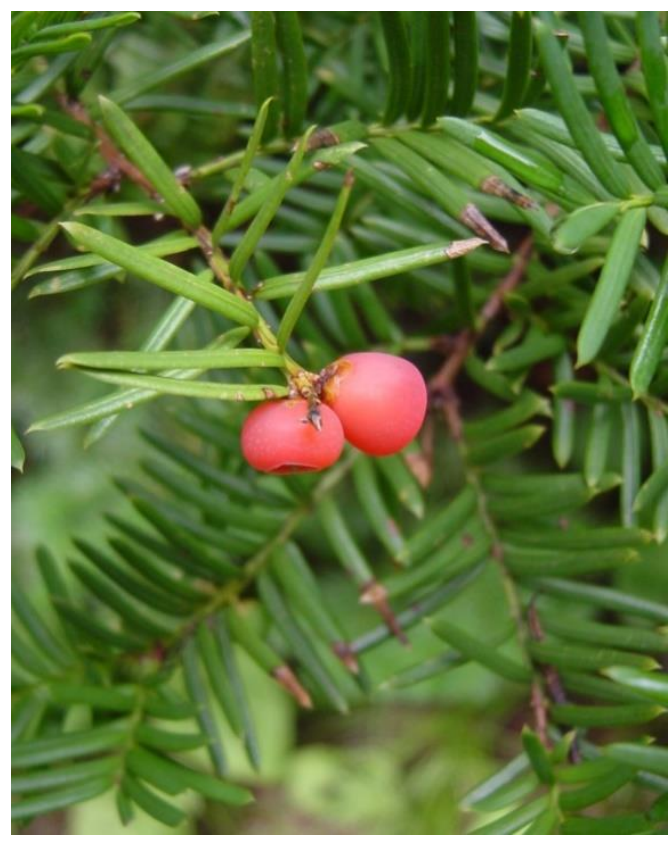

Женские шишки тиса остроконечного

В плодах, как известно, находятся семена - единицы расселения у цветковых и голосеменных растений. У первых наиболее крупные семена имеют опять же пальмы (сейшельская пальма - 9-11 кг), саговники и замии (до 8 см длины).

А самые крупные семена растений Приморья имеются у маньчжурского ореха (семейство Ореховые) и кирказона маньчжурского (семейство Кирказоновые). У последнего они треугольные, до 1 см ширины.

Самые мелкие семена свойственны представителям орхидных и заразиховых, их масса составляет сотые и тысячные доли грамма. О них мы еще поговорим. 


\section{А кой тебе годик?}

Каждый из нас знает, сколько ему лет, поскольку существует надежное свидетельство документ, зафиксировавший дату рождения. А как определить возраст того или иного живого организма? Ведь никакого ЗАГСа в живой природе не существует...

Знать возраст важно по различным причинам - и теоретическим, и практическим. Как без него определить длительность жизни организма, оценить темпы его роста, периодичность размножения, провести сравнительно-анатомические, эколого-популяционные исследования?

Оказывается, определить срок жизни какой-либо особи вовсе не так просто, как может показаться. Хотя в некоторых случаях надежные способы существуют. Так, для определения возраста млекопитающих используют такие признаки, как степень стёртости зубов, размер черепа, число роговых валиков на когтях и рогах, наконец, вес хрусталика глаза, годовые наслоения на зубах и костях. Лучшие методики позволяют определить возраст с точностью до месяца!

Определение длительности жизни растений также связано с различными трудностями. Это касается прежде всего трав. Как определить возраст той или иной травки в данный конкретный момент? Каких-то морфологических признаков, позволяющих сделать это, не существует, поэтому в большинстве случаев определение возраста травянистых растений связано с тщательными продолжительными наблюдениями.

Проще всего с растениями, живущими относительно недолго. Существуют виды, живущие лишь год (точнее, один вегетационный период), а затем отмирающие. Они получили название однолетних. В Приморье однолетние растения встречаются в самых разных семействах. Перечислим лишь некоторые из них.

Среди заносных и культивируемых растений это, например, представители семейств Лёновые (лён обыкновенный, крупноцветковый), Дербенниковые (дербенник иссополистный), Щирицевые (щирица Пальмера, багряная, гибридная и др.), Маревые (виды мари, лебеды), Гречиховые (виды гречихи), Бобовые (горох посевной, соя посевная, вигна угловатая, виды пажитника, фасоли, клевера), Мятликовые (виды вульпии, метлицы, овса, полевички, многобородника, канареечника, плевела, зайцехвостник яйцевидный) и др.

Много однолетников и среди аборигенных видов - это растения семейств Лёновые (лён стеллеровидный), Маревые (виды мари, телоксиса, лебеды, безвкусницы, кохии, верблюдки, солероса, сведы, солянки), Норчниковые (очанки Максимовича и уссурийская), Гречиховые (виды колючестебельника, горца, спорыша, хилокаликс пронзённолистный, головоцветник непальский и др.), Сытевые (виды камыша, ситовника, фимбристилиса и др.), Бобовые (виды куммеровии), Капустовые (ярутка полевая, пастушья сумка, крупка перелесковая, кноррингия восточная), Мятликовые (мелкочешуйник узловатый, мятлик однолетний) и др.

Среди однолетников есть особая группа растений, жизненный цикл которых проходит в очень короткое время - от двух недель до нескольких месяцев. Называются они эфемерами. Связан такой жизненный цикл с условиями существования, которые благоприятны только в определённые сроки, поэтому эфемеры встречаются в основном в пустынях, полупустынях, реже в степях. Такие растения максимально используют тот небольшой период, когда имеется влага (весна или осень), для своего воспроизводства. В Приморье эфемеров мало, поскольку климат края, особенно в южной его части, достаточно комфортен для многолетнего произрастания. В качестве примера можно назвать крупку перелесковую (дубравную) из семейства Капустовые. 


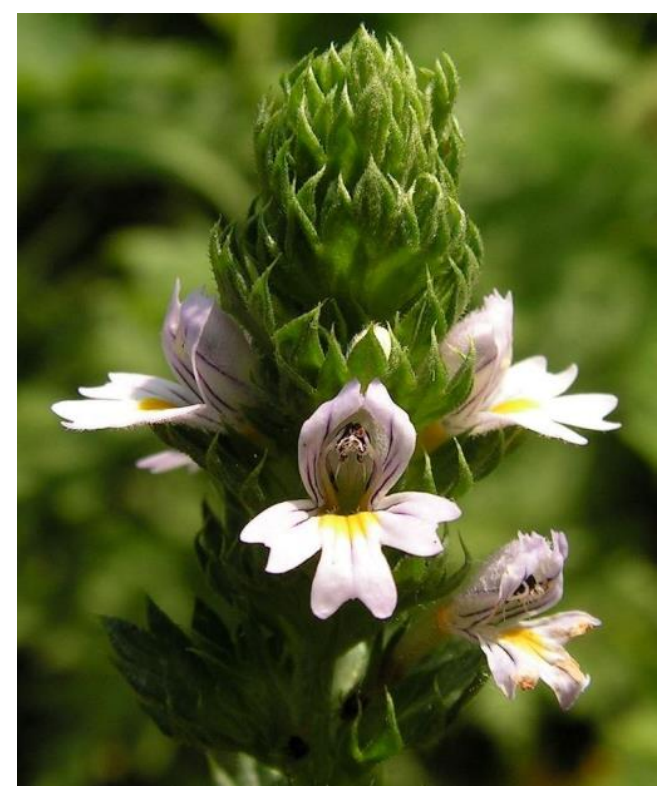

ОчанкаМаксимовича (https://www.plantarium.ru)

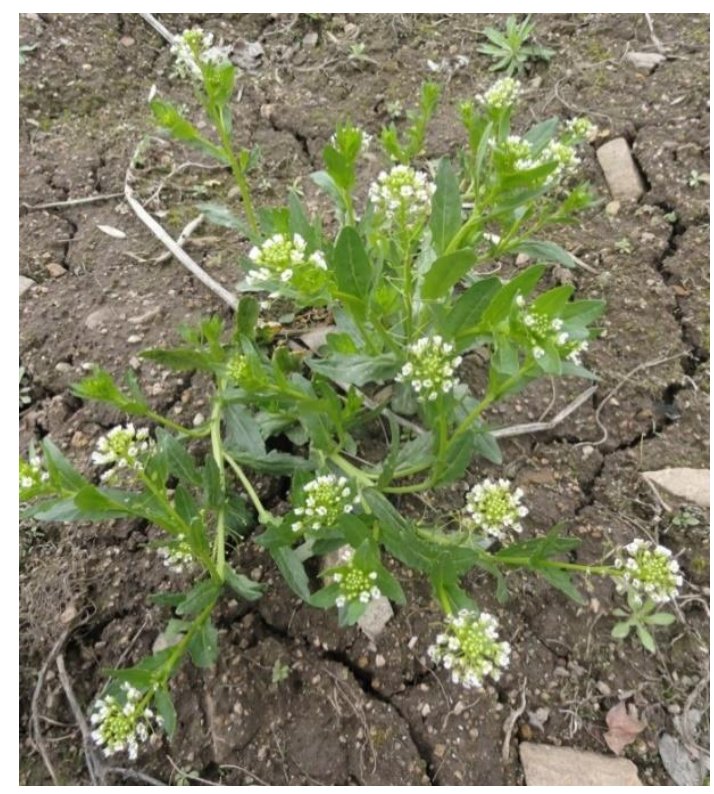

Пастушья сумка обыкновенная

Существует интересная группа двулетних растений. В первый год они накапливают питательные вещества, которые затем во второй год расходуют на образование цветков и плодов. В Приморье двулетники также являются как заносными, так и местными растениями.

Среди первых это, например, виды энотеры (прижатая и двулетняя) из семейства Кипрейные, растущие по пустырям, обочинам дорог. В первый год образуется розетка листьев, а во второй появляется цветоносный побег. Есть двулетники в семействе Астровые (Сложноцветные) - виды мелколепестника (аборигенный мелколепестник маньчжурский и заносной - едкий) и заносной чертополох поникающий. Из капустовых это заносной вид чесночница черешковая, изредка встречающаяся у дорог, и сурепка прямая, обычная на влажных лугах или в зарослях кустарников.

Немало растений проявляют себя одновременно как однолетники и двулетники. Например, резеда жёлтая из семейства Резедовые, липучка растопыренная из семейства Бурачниковые. А у капустовых (и не только у них) есть растения, которые проявляют себя как однолетники, двулетники и многолетниками.

Большая часть травянистых растений Приморья относится к многолетним. Их возраст определить совсем непросто, поскольку, как уже говорилось, для этого отсутствует надежный критерий. Однако в некоторых случаях о примерном возрасте все-таки можно судить; например, возраст женьшеня определяют по числу ежегодных приростов корневища, хорошо различимых невооруженным глазом.

Легче оценить возраст древесных растений - просто подсчитав годичные кольца на поперечном спиле ствола. Удивительно, но впервые об этом догадался гениальный Леонардо Да Винчи! Каждой весной в стволе «просыпается» образовательная ткань (камбий) и начинает формировать новые клетки. Сначала это происходит энергично, интенсивно, но к осени деятельность камбия ослабляется. Переход от осенних тканей к весенним достаточно чёткий, заметен визуально в виде кольца. Конечно, пилить дерево нет необходимости, достаточно воспользоваться особым буравом, и тот извлечёт узкий цилиндр, на котором можно подсчитать число годичных колец. Но всё же и этот способ не идеален. Самые первые годичные 
кольца могут быть незаметными, кроме того, бывают годы неблагоприятного роста, а иногда дерево дает два кольца в один год.

Какие же рекорды долгожительства ставят живые организмы?

Возраст большинства животных небольшой, а некоторые вообще существуют лишь несколько часов, например, некоторые поденки.

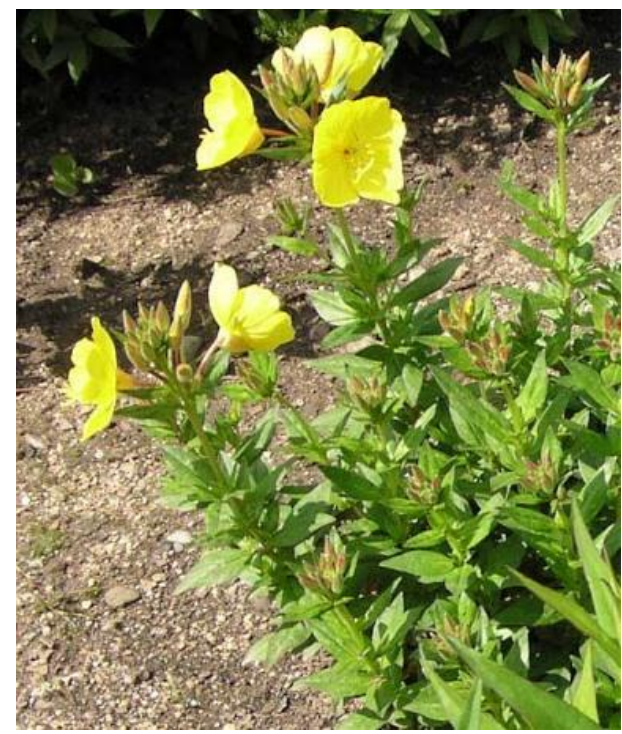

Энотера двулетняя (https://ru.wikipedia.org)

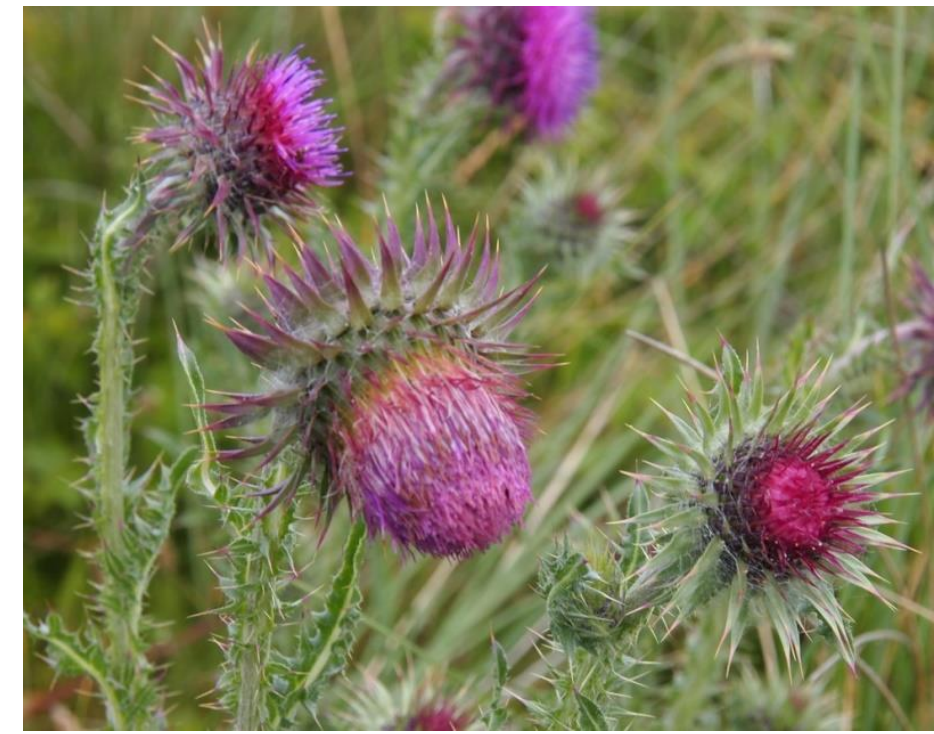

Чертополох поникающий (https://ru.wikipedia.org)

Но и у животных есть свои долгожители, это, конечно, хордовые, причём из разных систематических групп. У рыб наиболее почтенного возраста достигают щуки. В 1497 году в одном из озер близ Гейльбрунна была поймана щука весом в 140 кг и длиной 5,7 метра. На кольце сохранилась надпись: «Я первая рыба, которую собственноручно пустил в озеро Фридрих II, 5-го октября 1230 года». Этой щуке было 267 лет. Довольно много живут алеутский морской окунь (до 200 лет), сомы (до 100 лет), карпы (до 150 лет). Из пресмыкающихся старцами являются черепахи и крокодилы (до 170 лет). У птиц рекорды принадлежат грифам, попугаям и воронам, способных прожить (особенно в неволе) до 80-100 лет. У млекопитающих до 200 лет живут киты, до 70 лет - слоны.

Растения и здесь превосходят животных. Возраст индийских баньянов доходит до 3000 лет, африканских баобабов - до 4000 лет. Около 20 экземпляров сосны растут в горах Уайт-Маунтинс (Калифорния), и всем им более 4000 лет (а одному даже около 4600 лет).

Считают, что возраст калифорнийских секвойядендронов доходит до 5000 лет (хотя гарантированно у них подсчитано несколько более 3000 колец), а Макрозамии (саговниковые) в Австралии, как говорят, насчитывают даже до 12 тыс. лет, но у них нет годичных колец, поэтому это является сомнительным.

Совсем недавно в Швеции нашли ель, возраст которой, по данным радиоуглеродного анализа, составил... 9,5 тыс лет. Хотя это возраст не ствола, которые, сменяя друг друга, достигали «лишь» 600 лет, а корней.

Деревья Приморского края не отличаются таким завидным возрастом, хотя долгожители среди них также есть. 
Так, двухтысячелетнего возраста может достигать тис остроконечный (семейство Тисовые), до 500 лет доживают сосна корейская, лиственница, пихта цельнолистная (семейство Сосновые), дуб монгольский (семейство Буковые). Большинство деревьев живёт 80-100 лет, хотя следует отметить, что продолжительность жизни часто зависит от внешних факторов, прежде всего пожаров. Тем больше стрессовых факторов, тем меньше жизнь дерева. Так, по словам дальневосточного ботаника В.М. Урусова, на о. Петрова, где пожары очень редки, находили экземпляры актинидии острой 400-летнего возраста!

Среди травянистых растений рекордсменом-долгожителем является женьшень. Возраст самых старых растений может доходить до 200 лет. Нужно сказать, что для этого легендарного растения из семейства Аралиевые свойственна интересная биологическая особенность. Периодически он может впадать в состояние покоя (т.н. «сон» женьшеня), что вызвано повреждением почки возобновления. Этот «сон» длится обычно не более года, но в редких случаях может продолжаться десятилетиями. Считается, что эта особенность характерна для реликтовых растений.

Остальные травы живут гораздо меньше. Однако возможен и иной подсчет. При вегетативном размножении часто происходит образование дочерних особей (как, например, у земляники, размножающейся усами), являющихся генетически идентичными родительским растениям. Постепенно связь этих дочерних особей с материнским растением утрачивается, и тогда образуется клон, насчитывающий зачастую многие десятки отдельных особей. Так вот, если считать возраст целого клона, который является производным одного растения, то тогда цифры будут гораздо большими. Например, возраст клона люцерны посевной (семейство Бобовые) может приближаться к 1000 лет, а клоны свободноягодника колючего (элеутерококка) из семейства Аралиевые дают возраст в 300 лет. Более того, некоторые учёные считают, что клоны вегетативно размножающихся растений (папоротника-орляка, например) могут быть вообще потенциально бессмертными.

Таким образом, хотя и существуют рекорды долгожительства среди растений, возраст большинства из них (прежде всего древесных) составляет 70-100 лет. 


\section{Глава 2. Растения, приковывающие взгляд}

Любой живой организм на нашей планете имеет определённый внешний облик, или жизненную форму, представляющую собой результат взаимодействия организма с внешней средой. Учитывая, что организмы населяют самые разные среды обитания, число их жизненных форм также весьма значительное. Не составляют исключения и растения, которые отличаются разнообразием не только жизненных форм, но и вообще морфологических особенностей, связанных с приспособлением к условиям произрастания.

Есть растения, глядя на которые нельзя не удивляться: и выдумала же природа такое чудо! А удивляться можно многому - красоте цветков, необычной форме листьев, разнообразию формы плодов. В любом представителе мировой флоры можно найти свою «изюминку», даже у какого-нибудь невзрачного на первый взгляд растения более внимательный наблюдатель откроет массу необычных черт.

В наибольшей степени морфологическое разнообразие свойственно, безусловно, растениям тропиков. Однако и видам Приморья тоже есть чем похвастаться.

Взять хотя бы виды триллиума из семейства Триллиумовые - камчатский (встречается лишь на севере Приморья) и ромболистный (растёт на юге края). У этих растений число многих органов равно или кратно трём - три листа, три белых либо бледно-розовых крупных внутренних листка околоцветника и три зеленоватых внутренних, и шесть тычинок. Кроме того, для них свойственна хемолюминесценция. Её удалось наблюдать дальневосточному ботанику А.П. Нечаеву - в вечернее время над цветками триллиума появляется голубоватое мерцающее свечение, исчезающее с наступлением темноты.

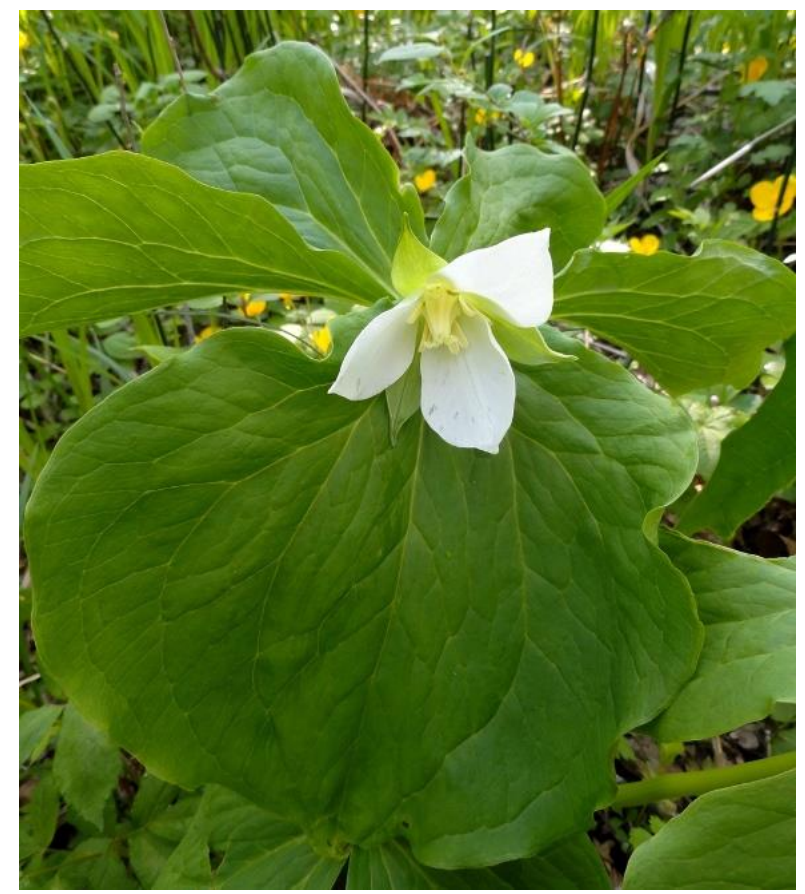

Триллиум ромболистный

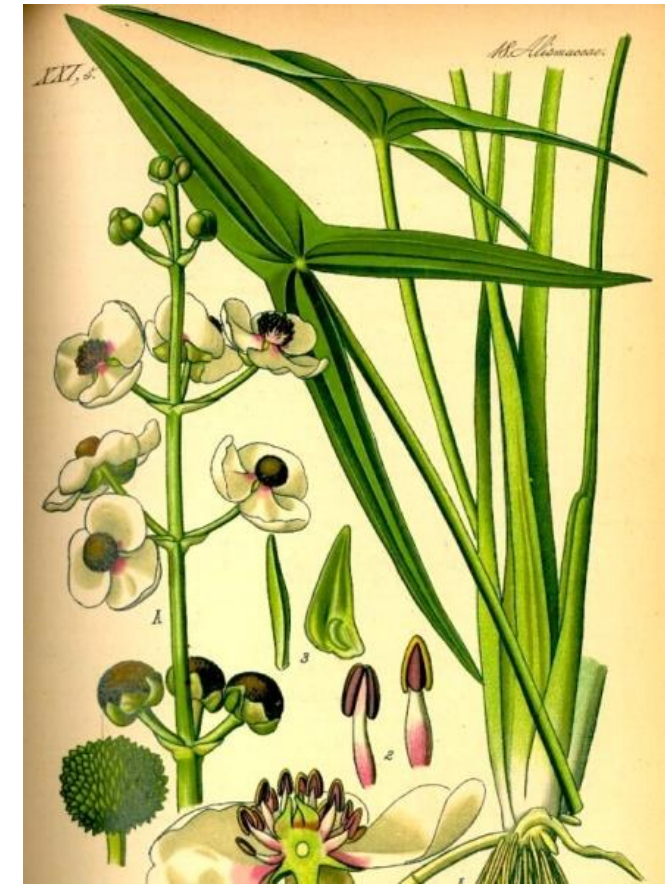

Стрелолист плавающий (https://ru.wikipedia.org)

У некоторых растений наблюдается весьма интересная особенность, связанная с формой листовых пластинок. Обычно они имеют одинаковую форму, различаясь лишь размера- 
ми. Но есть и такие виды, которые на одной и той же особи развивают листья разной формы. Это явление получило название гетерофиллии.

В большей степени она свойственна водным (точнее, полупогруженным) растениям. Яркий пример гетерофиллии представляет стрелолист из семейства Частуховые. В наибольшей степени она выражена у стрелолиста плавающего, обитающего в озерах и старицах края. Его подводные листья линейные, удлинённые, плавающие листья большей частью эллиптические, а надводные имеют стреловидную пластинку. В меньшей степени гетерофиллия свойственна другому виду - стрелолисту трёхраздельному. Различие в форме подводных и плавающих листьев наблюдается также у красовласки болотной, или водяной звёздочки (семейство Красовласковые) и видов рдеста (семейство Рдестовые). Так, у некоторых видов рдеста (например, рдеста гребнеплодного, растущего по стоячим водоёмам) подводные листья линейные, а плавающие - эллиптические.

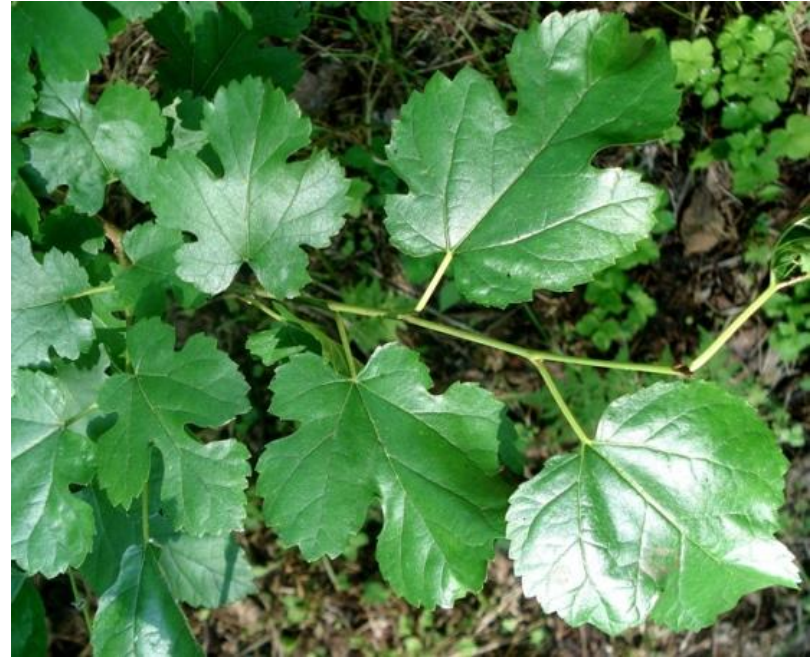

Гетерофиллия у шелковицы белой

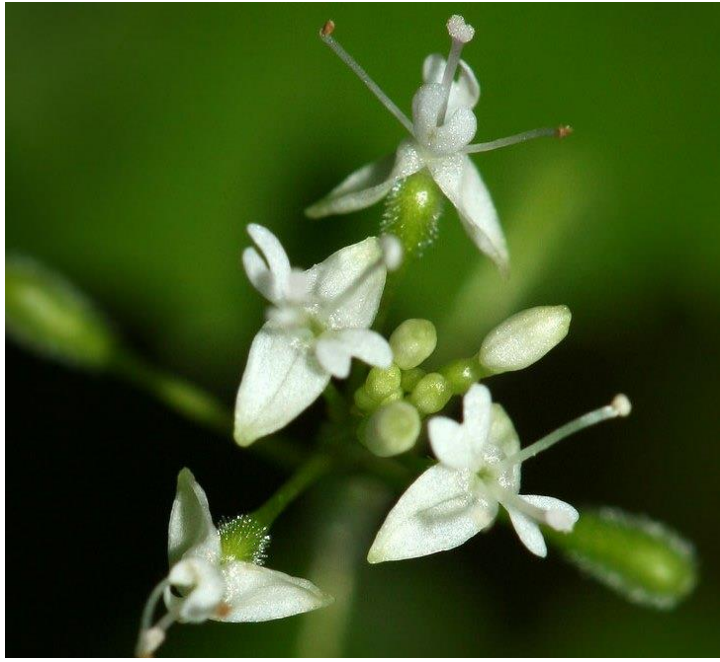

Цветки двулепестника альпийского (http://www.ljplus.ru)

У наземных растений гетерофиллия также встречается. Стеблевые сложные листья нередко отличаются друг от друга числом листочков и их формой. Цельные листья могут быть разной формы на одном побеге - например, у шелковицы белой из семейства Тутовые нередко можно видеть одновременно листья с цельной, лопастной и раздельной листовой пластинкой. У заносного растения короставника полевого из семейства Ворсянковые нижние листья цельные, а верхние - перистораздельные. Это же наблюдается у другого представителя семейства - скабиозы шерстистолистной, растущей по сухим лугам.

У видов двулепестника из семейства Кипрейные, как можно судить по названию, необычное число лепестков - их всего два. В Приморье произрастают 5 видов этого рода, лесных многолетников от 20 до 120 см высоты. Можно добавить, что парные у этих растений не только лепестки, но также чашелистики и тычинки.

По мелководью Японского моря растут три вида небольшого, включающего около 15 видов, рода взморник - стеблеобразующий, морской и японский. У взморников очень необычная пыльца - она удлиненная, нитевидная. Пыльцевое зерно переносится водой и обматывается вокруг рыльца женского цветка, после чего и происходит опыление. Столь же экзо- 
тично опыление и у других водных растений, но обитающих в пресных водоёмах - некоторых видов рдеста, роголистника (семейство Роголистниковые) и др.

Цветки обычно собраны в соцветия самой разной структуры. Среди них бывают и весьма необычные. Так, у мытника перевёрнутого из семейства Норичниковые соцветие верхушечное, из почти сидячих неправильных цветков с серповидно изогнутым шлемом, нередко располагающихся почти в одной плоскости. А у лугового растения скрученника китайского из семейства Ятрышниковые (Орхидные) бело-розовые цветки закручены в плотную изящную розово-белую спираль до 14 сантиметров длины.

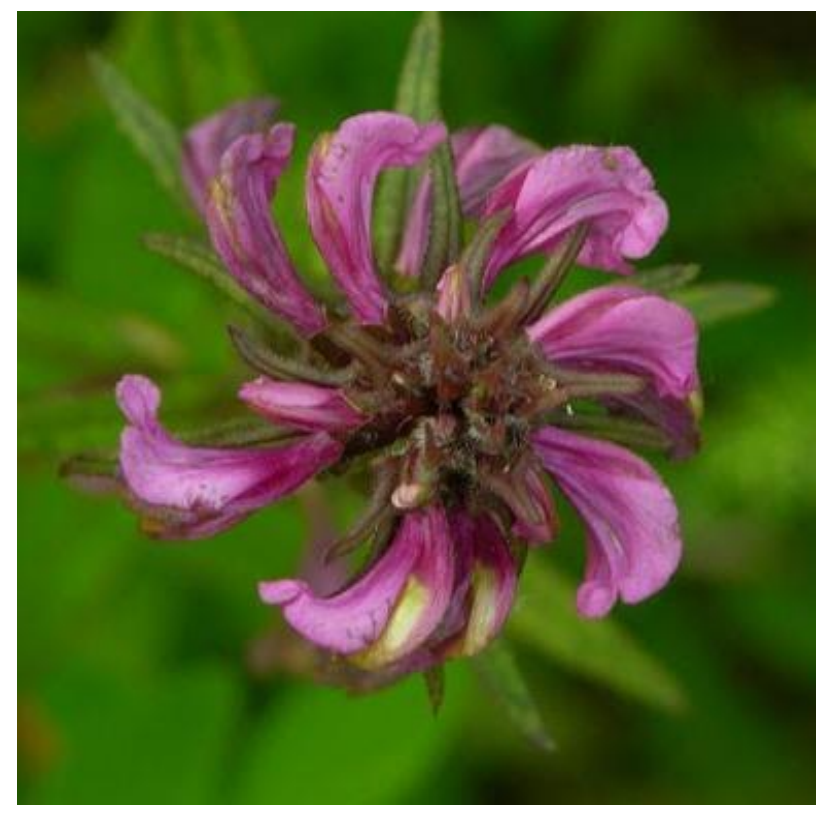

Соцветие мытника перевёрнутого (https://www.plantarium.ru)

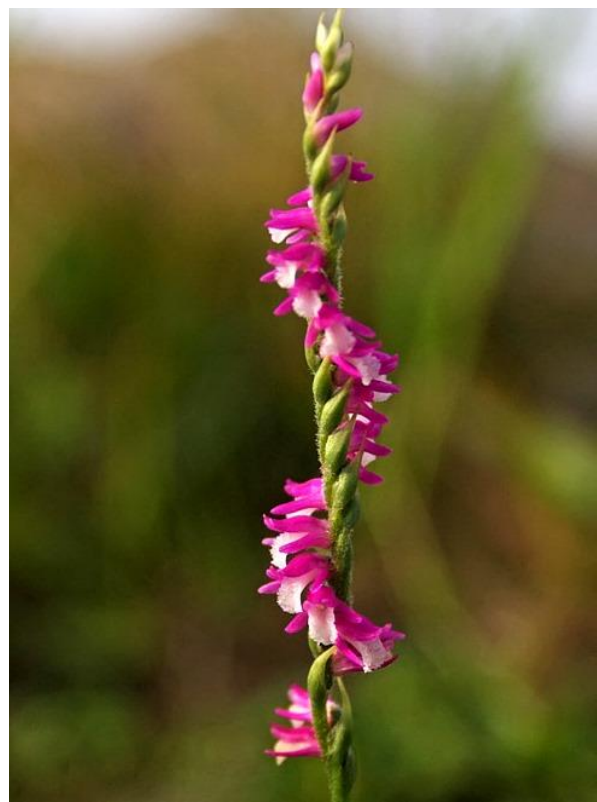

Соцветие скрученника китайского (https://www.plantarium.ru)

Морфологические особенности корней редко удивляют человека. Но одно, можно сказать легендарное лекарственное растение Приморья известно в том числе благодаря особой форме корней. Это женьшень настоящий из семейства Аралиевые. Само его название переводят с китайского как «человек-корень». Корень растения действительно нередко напоминает фигуру человека. Вызвано это наличием у женьшеня контрактильных, или втягивающих, корней. Такие корни способны ежегодно сокращать свои ткани, втягивая на некоторую глубину в почву корневище. Дело в том, что при этом в почву погружаются и почки возобновления, что в определённой степени защищает их от вымерзания в зимний период. Сокращаясь, главный корень женьшеня тянет за собой боковые отростки, находящиеся обычно в верхней части. Они сдвигаются также в верхней части, что приводит к их изгибу, из-за чего они становятся похожи на согнутые в локтях руки. Отростки, которые находятся в нижней части главного корня, не изгибаются, остаются прямыми и похожи на «ноги».

Нужно сказать, что удивлять может не только внешний вид, но и различные физиологические и экологические особенности, которые в глаза не бросаются, а требуют более внимательного взгляда.

К примеру, растения не способны к активным передвижениям, но двигаться могут отдельные их органы, и даже весьма живо. Долгое время самым быстрым считалось смыкание ловчего аппарата венериной мухоловки, которое происходит со скоростью около 100 милли- 
секунд. Однако совсем недавно выяснилось, что более «резвым» является дёрен канадский (семейство Кизиловые) - выбрасывание пыльцы во время раскрытия цветков осуществляется всего за 0,4 миллисекунды! Вначале, за 0,2 миллисекунды, отходят лепестки, а затем тычинки, ускоряясь в две тысячи раз (что в 800 раз больше силы, испытываемой астронавтами во время взлёта), выбрасывают пыльцу.

У кувшинки четырёхгранной из одноимённого семейства цветоножки после опыления спирально скручиваются, что приводит к погружению цветка. Впоследствии, после созревания семян и разрушения плода, семена, окружённые слизистым чехлом с воздушными полостями, всплывают на поверхность и разносятся течениями или волнением.

Поговорим о том, чем же еще растения привлекают внимание человека.

\section{Не тронь меня!}

Существует немало растений, имеющих различные острые образования - от кактусов и молочаев до пальм и панданусов. Появление таких образований - не просто игра природы, нередко доставляющая неприятности человеку. Они выполняют важную защитную функцию, значительно при этом варьируя по своим размерам, форме и расположению.

Основным критерием, который разделяет их на две большие группы, является происхождение. В одном случае они представляют собой видоизменённые органы и называются колючками, в другом - являются выростами покровных тканей и носят название эмергенцев.

Видоизменение - это наследственное морфолого-анатомическое изменение органа, связанное со сменой выполняемой им функции. Например, основная функция листа - осуществление фотосинтеза. Однако в некоторых случаях листья начинают, например, улавливать насекомых, преобразуясь при этом в ловчие аппараты различной формы. Если это преобразование закрепилось генетически, значит, произошло видоизменение (метаморфоз).

Колючки встречаются у деревьев и кустарников, а эмергенцы имеются как у древесных, так и у травянистых растений. У деревьев и кустарников эмергенцы представлены шипами.

Как отличить колючки от шипов? Во-первых, шипы на побеге располагаются не только в узлах, но и на междоузлиях, где колючек не встретишь. Кроме того, шип, приложив некоторое усилие, можно отделить от стебля. С колючками это не пройдёт: их ткани представляют с тканями стебля единое целое, из стебля в колючки заходят проводящие пучки («трубопроводы» растения, по которым транспортируются минеральные и органические вещества), поэтому отделить от стебля их нельзя, можно только сломать или вырвать с частью самого стебля.

Колючки, в отличие от шипов, могут, как и обычные побеги, ветвиться. У наших приморских растений ветвления колючек не происходит, но, например, у североамериканского интродуцента гледичии трёхколючковой из семейства Бобовые, встречающейся в ботанических садах и дендрариях края, это наблюдается.

Имеется и явное различие в анатомии - колючки листового происхождения повторяют в основных чертах строение листа, побегового - побега.

Наконец, в некоторых случаях из почек, имеющихся на колючках побегового происхождения, могут развиться листья, если поместить побег в условия повышенной влажности. Это говорит о том, что основная причина видоизменения листа или побега в колючку - сокращение расходования воды растением, что важно в условиях недостатка влаги (вспомните 
кактусы). А поскольку это видоизменение стало еще и острым, оно выполняет и вторичную защитную функцию.

В отличие от колючек, защитная роль шипов является самой главной. Как еще оградить себя от непрошенных «гостей», которые не прочь полакомиться сочными листьями или плодами? Впрочем, даже обильные шипы не являются идеальной защитой. На Дальнем Востоке пятнистый олень, например, охотно объедает стволы одного из самых наших неприступных растений - аралии высокой из семейства Аралиевые. А уж ее «вооружению» можно только позавидовать...

Наконец, некоторые растения с помощью колючек и эмергенцев прокладывают себе путь. Это свойственно представителю семейства Розовые шиповнику Максимовича - лиановидному кустарнику, произрастающему по склонам морского побережья. Его стебли густо усеяны изогнутыми шипами, которыми он и цепляется за ветви рядом растущих кустарников. Этот же способ роста характерен и для некоторых травянистых растений, стебли которых несут острые эмергенцы. Наиболее типичный пример - гумулопсис лазящий из семейства Коноплевые. Эту однолетнюю лиану можно увидеть вдоль дорог, близ жилья, на лесных опушках и огородах. Его эмергенцы настолько острые, что при неосторожном «обращении» могут сильно оцарапать, из-за чего это растение получило прозвище «резучка». Крючковидные эмергенцы различных размеров имеются на стеблях различных видов марены и подмаренника из семейства Мареновые, они также облегчают им рост, способствуя более или менее прочному прикреплению к находящейся рядом опоре.

В колючки видоизменяются надземные части древесных растений Приморья - лист, прилистники, почечные чешуи, часть побега или побег целиком.

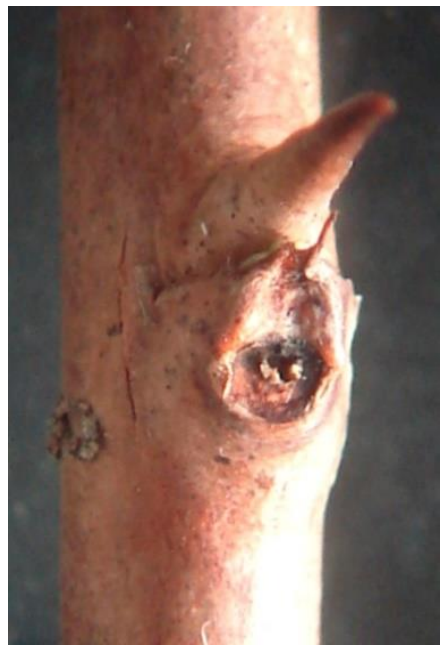

Плоскосемянник китайский Боярышник перистонадрезанный

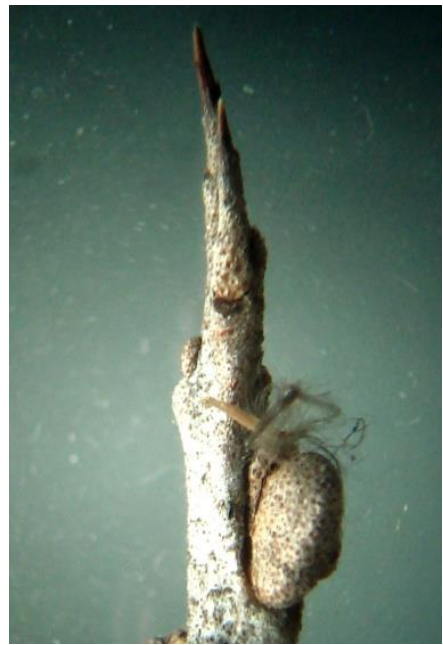

Облепиха крушиновидная

В Приморье чаще встречаются растения с видоизменёнными в колючки побегами. Как правило, эти колючки небольшие, до 2-3 сантиметров длины, неразветвлённые, с незаметными или вполне различимыми невооружённым глазом, хотя и мелкими, почками. 


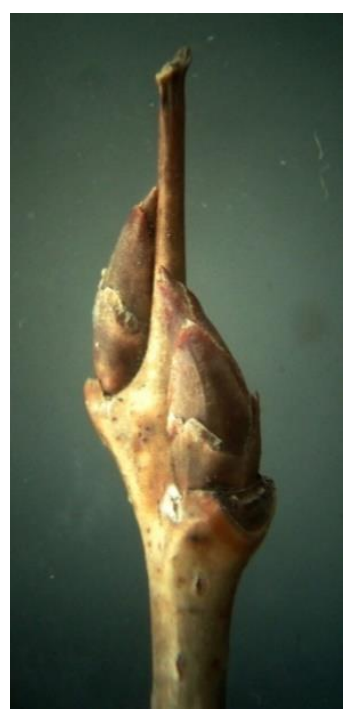

Жёстер уссурийский

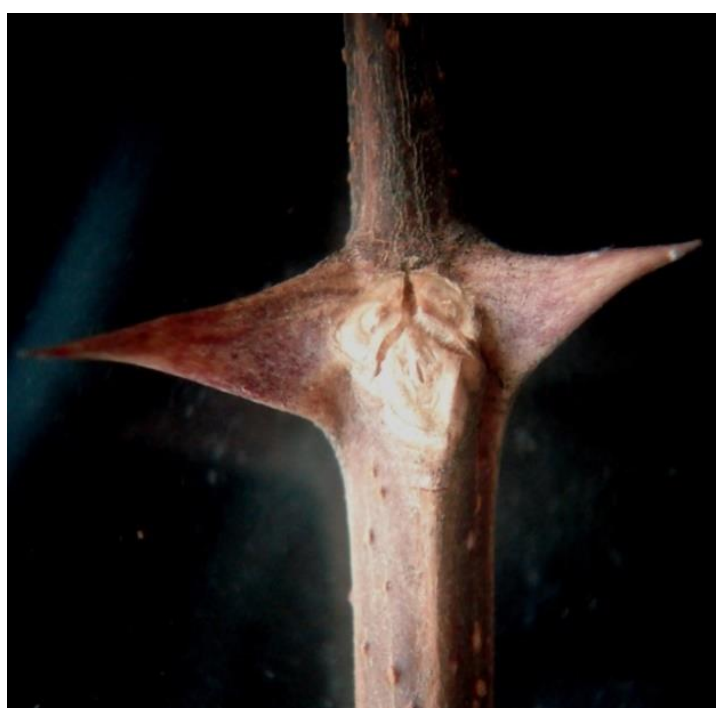

Робиния ожноакациевая

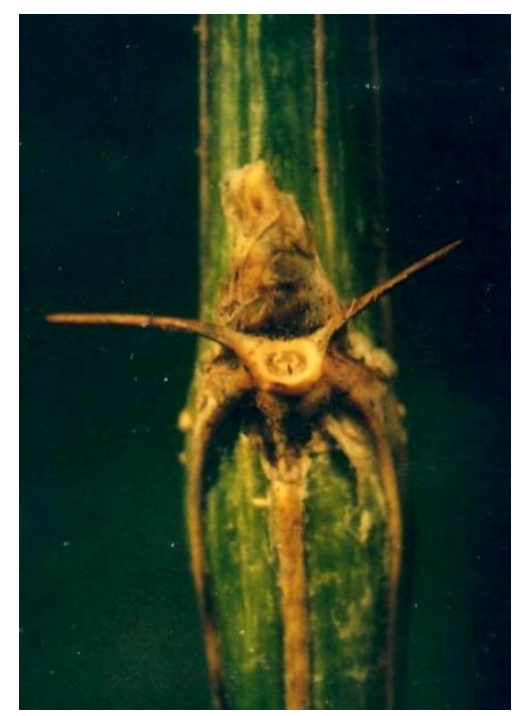

Карагана древовидная

Так, у плоскосемянника китайского (или принсепии китайской) из семейства Розовые колючки не превышают сантиметра в длину и обычно несколько изогнуты книзу. Под колючкой располагается почка. А вот у боярышников (у нас их три вида - перистонадрезанный, Максимовича и даурский) и груши уссурийской из этого же семейства колючки более крупные, до 3-3,5 сантиметров, в их основании можно заметить мелкие почки.

В некоторых случаях постепенно заостряется вполне обычный облиственный побег, что наблюдается у облепихи крушиновидной (семейство Лоховые), широко культивируемой в качестве плодового и лекарственного растения. Кто собирал её целебные плоды, обязательно вспомнит и о колючках, уколы которых ощутимы и болезненны. А у жёстера уссурийского из семейства Крушиновые колючка, венчающая побег и достигающая 1,5-2 см длины, гораздо тоньше самого стебля. Этот крупный кустарник, иногда принимающий древовидную форму, произрастает по долинам рек - на прилегающих скалах или отмелях, a также в долинных лесах.

В семействе Бобовые встречаются древесные растения с колючками, которые по своему происхождению являются видоизменёнными прилистниками. Прилистники - это парные листоподобные выросты, развивающиеся в основании черешка листа. Превращённые в колючки прилистники имеются у робинии ложноакациевой и караганы древовидной. Робиния - интродуцент, т.е. пришелец в нашем крае, успешно используемый в озеленении и нередко дичающий. Родиной этого дерева с обильными белыми цветками, из-за чего его называют «белой акацией», является Северная Америка. Колючки робинии твёрдые, мощные, у порослевых и молодых экземпляров крупные, до полутора-двух сантиметров длины. Колючки караганы древовидной более мелкие, тонкие, легко ломающиеся. Этот вид также пришлый для Приморья, родом он из Сибири и Монголии, но так же, как и робиния, часто используется в озеленении. Нужно сказать, что и у другого, местного вида рода карагана - караганы уссурийской прилистники к осени твердеют, но они ещё менее прочные, чем у древовидной, и часто опадают.

Есть среди наших растений кустарник, у которого в колючки видоизменяются листья. Это барбарис амурский из одноименного семейства, часто встречаемый в наших лесах. Его колючки, как правило, трёхраздельные, но нередко встречаются как простые (чаще у верхушки побега), так и пяти-семираздельные колючки. 
Наконец, у древогубца плетеобразного, древесной лианы из семейства Древогубцевые, произрастающей по долинным лесам, в колючки - мелкие, но прочные и острые, - видоизменяются наружные почечные чешуи. С их помощью молодой побег взбирается по своей опоре - стволу находящегося рядом дерева.

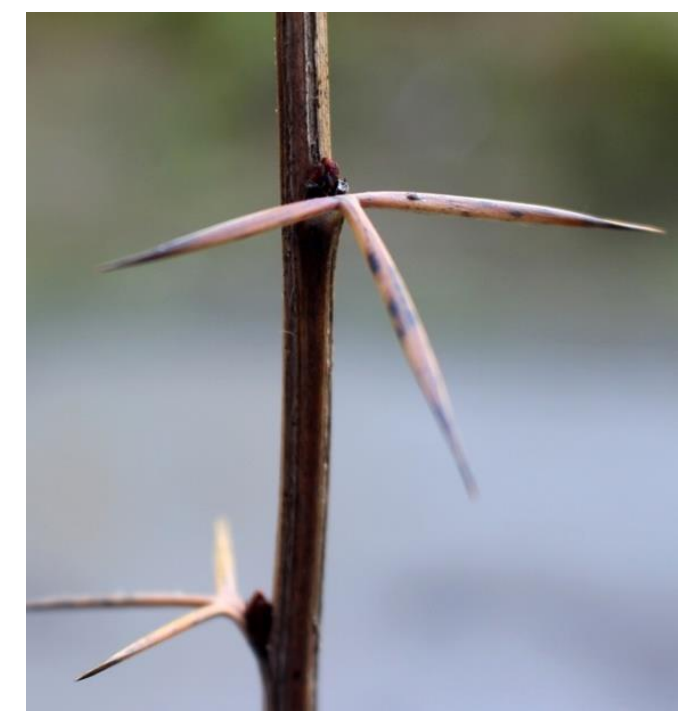

Барбарис амурский

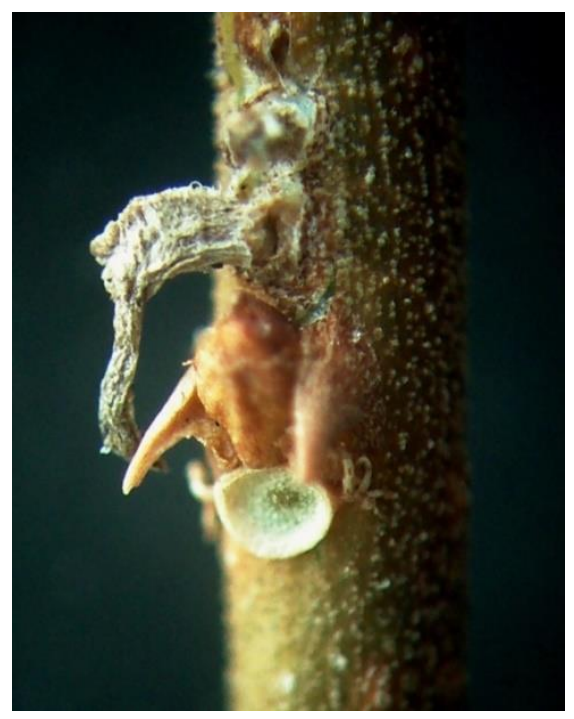

Древогубец плетеобразный

Вот, пожалуй, и все древесные растения Приморского края, имеющие колючки. У гораздо большего числа видов растений встречаются острые эмергенцы - шипы, в образовании которых принимают участие не только эпидерма (первичная покровная ткань), но и более глубоко залегающие ткани.

Из растений Приморья наиболее богато «шипастыми» растениями семейство Аралиевые. В него входят родственники знаменитого женьшеня - свободноягодник, аралия, заманиха и калопанакс.

Наиболее известен, особенно для тех, кто любит лесные походы, свободноягодник колючий, или, как чаще говорят, элеутерококк. Это известное лекарственное растение, двухпятиметровый кустарник с пятипальчатосложными листьями и зонтиками беловатых цветков.

Любому таёжнику знакома ситуация, когда, спускаясь по особо крутой сопке, набираешь слишком большую скорость и стараясь затормозить, хватаешься за всё, что попадается на пути. Это «работает» лишь до тех пор, пока на пути не повстречается элеутерококк. Схватился за его стволик - и тут же отдёрнул руку и закричал от боли, поскольку в руку тут же вонзились десятки тонких игловидных шипов. Мало того, спустя некоторое время места уколов, если вовремя не удалить шипы, начинают болеть, а сами шипы погружаются ещё глубже в кожу. Невольно чертыхнёшься с досады. Неудивительно, что одно из народных названий элеутерококка - чёртов куст. У шипов элеутерококка есть одна интересная особенность - большинство из них направлено книзу, но шипы, находящиеся в узле, грозно смотрят вверх, защищая почку.

У другого вида, свободноягодника сидячецветкового (или акантопанакса), шипы немногочисленные, они более толстые и, в отличие от элеутерококка, сильно расширяются к своему основанию. А вот у заманихи высокой, произрастающей в высокогорных пихтовоеловых лесах на высоту 800-1500 м над уровнем моря, напротив, практически все надземные 
части растений (кроме лепестков и плодов) покрыты многочисленными тонкими игловидными шипами.

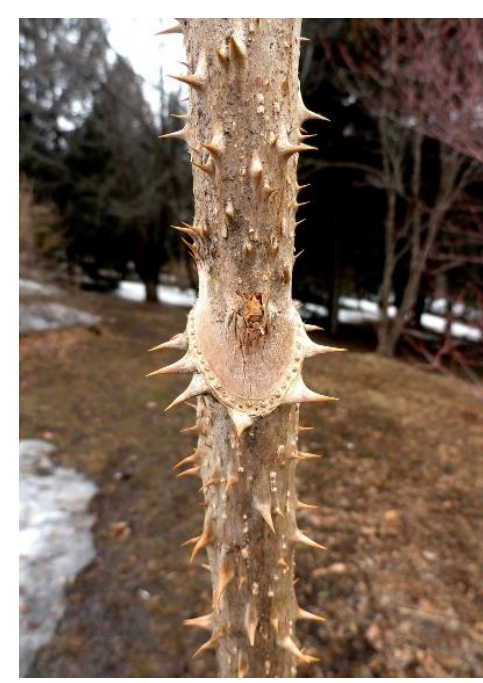

Аралия высокая
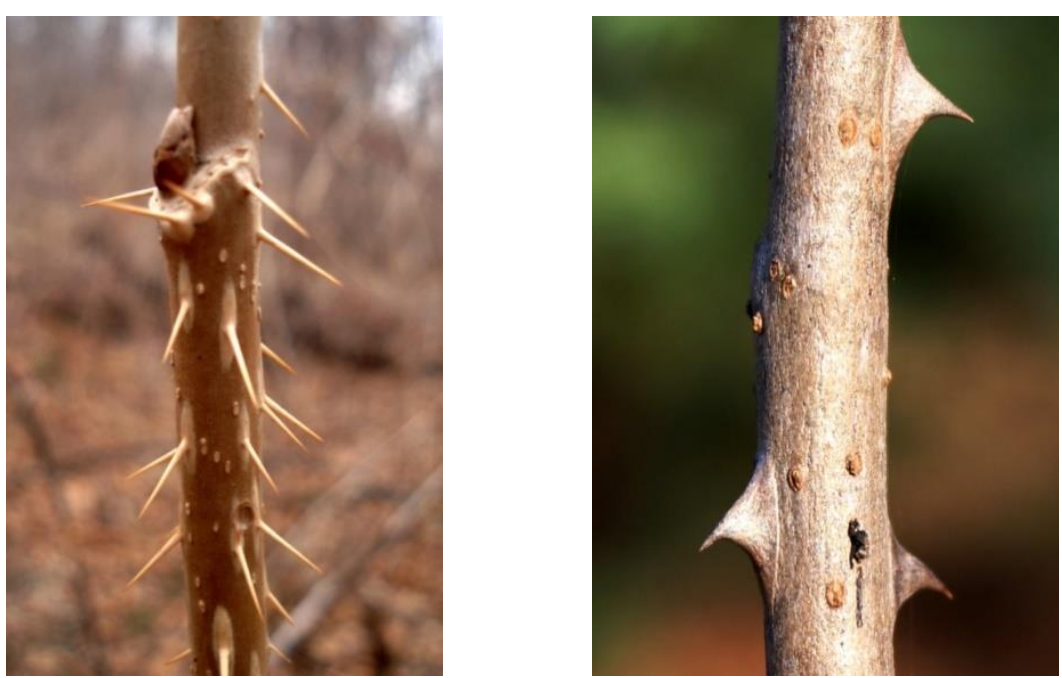

Наиболее мощные шипы образуются у аралии высокой (маньчжурской). Кто бывал в лесу, не забудет встречу с этим интересным реликтом. У аралии своеобразная пальмовидная крона из крупных сложных листьев, а стволик густо усеян прочными шипами. Как и в случае с элеутерококком, уколы от аралиевых шипов впоследствии также через некоторое время начинают болеть. Шипы, кстати, у аралии находятся не только на стебле, довольно много их бывает и на листьях (на черешках, черешочках и главных жилках листочков). Следует отметить, что встречаются экземпляры аралии и почти совсем без шипов.

Шипы калопанакса семилопастного, ещё одного представителя аралиевых, более мелкие (крупные лишь на порослевых побегах) и в целом менее острые, но зато они сохраняются на стволах даже старых деревьев!

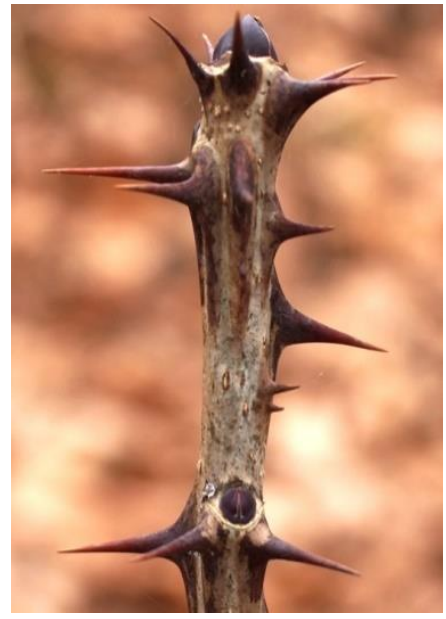

Калопанакс семилопастный
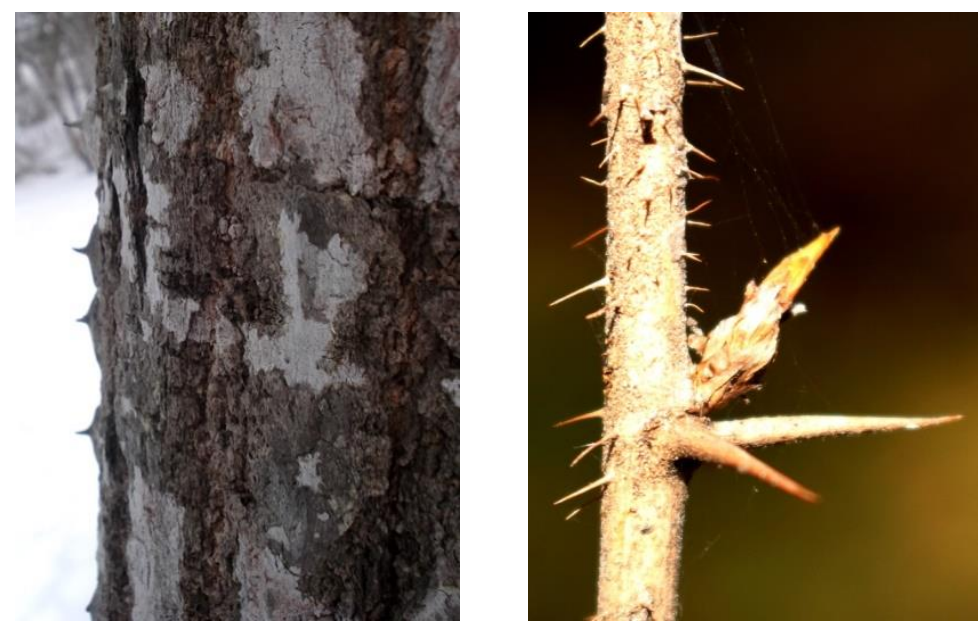

Калопанакс семилопастный, Крыжовник буреинский шипы на стволе 
В семействе Розовые шипы имеются у видов шиповника и малины, а в семействе Крыжовниковые - у крыжовника буреинского, смородин ощетиненной и двуиглой. Как правило, у этих растений междоузлия покрыты многочисленными мелкими шипами, зато в узлах они более крупные, парные или, реже, в большем числе.

Травянистых растений с острыми эмергенцами немного. Яркий пример - жгучие волоски крапивы. Это многоклеточные образования, причём оболочки клеток пропитаны солями кремния, из-за чего волоски получаются твёрдыми, но довольно хрупкими. Вонзился такой волосок в кожу - и сразу обломился. При этом содержимое этого миниатюрного «шприца» (смесь из гистамина, ацетилхолина и органических кислот) раздражает кожу, заставляя пережить немало неприятных минут. Крапивовые представлены в Приморье семью родами, но лишь у представителей трёх из них - крапива, лапортея и жирардэния - есть жгучие эмергенцы. Листья однолетнего растения лапортеи клубненосной, растущей в хвойношироколиственных лесах, даже в засушенном виде сохраняют свою жгучесть десятки лет!

Мощные эмергенцы есть у такого реликтового водного растения, как эвриала устрашающая из семейства Кувшинковые. Она встречается по озерам и старицам рек Илистая и Уссури. Свой грозный видовой эпитет она получила не зря - крупные шипы покрывают практически все её части, кроме лепестков и корней. Это редкое растение внесено в Красную Книгу Приморского края.

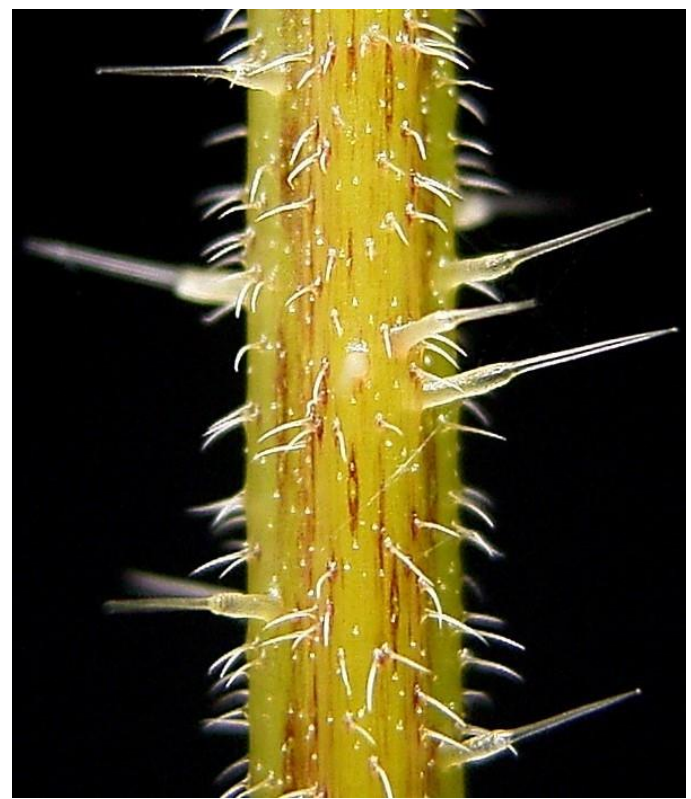

Жгучие эмергенцы крапивы (https://upload.wikimedia.org)

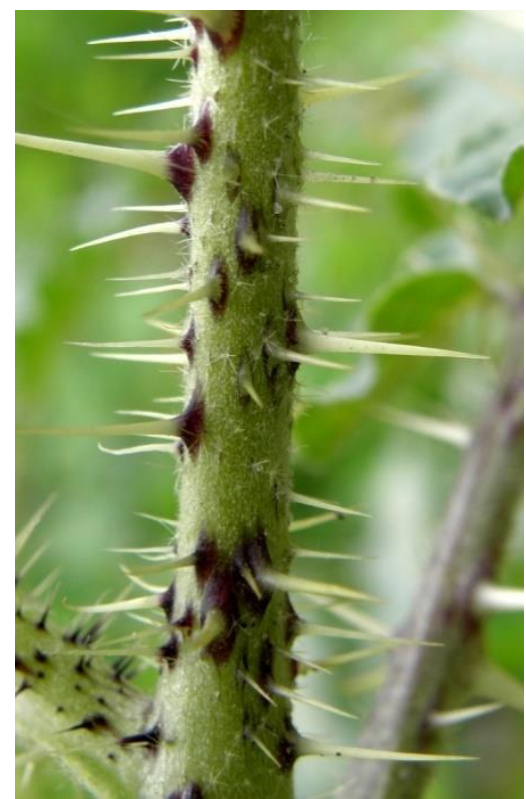

Эмергенцы паслёна рогатого (https://ru.wikipedia.org)

Обильно снабжён эмергенцами ещё один представитель Красной книги Приморья мордовник рассечённый из семейства Астровые. Это редкое растение произрастает по остепнённым открытым склонам на юго-западе Приморья в Октябрьском и Пограничном районах. Доли его листовых пластинок оканчиваются довольно мощными остриями. У других представителей семейства, видов рода бодяк, небольшими эмергенцами заканчиваются зубцы листовых пластинок.

Довольно крупные, до 1 см длины, эмергенцы (шипы) имеет представитель семейства Паслёновые паслён рогатый. Это карантинный сорняк, растущий по сорным местам и желез- 
нодорожным насыпям. К эмергенцам относят также и волоски насекомоядного растения росянки, речь о которой ещё впереди.

Эмергенцами иногда покрыты стебли травянистых растений, что в некоторой степени помогает их росту. Это свойственно хмелю и гумулопсису из семейства Коноплевые (у них эмергенцы т-образные), колючестебельнику и хилокаликсу из семейства Гречиховые, подмареннику даурскому и марене сердцелистной из семейства Мареновые. У острицы простёртой, однолетнего растения из семейства Бурачниковые, встречающегося вдоль дорог и по сорным местам, стебли по рёбрам с многочисленными крючковидными, книзу направленными эмергенцами. А у североамериканского интродуцента эциноцистиса лопастного из семейства Тыквовые, культивируемого в качестве декоративного растения и часто дичающего, эмергенцами обильно покрыты плоды.

Острые эмергенцы, которыми снабжены плоды некоторых растений, служат для их весьма эффективного расселения. Но об этом мы ещё поговорим.

\section{Растения с видоизмёненными или отсутствующими органами}

Для животных и высших растений характерно наличие органов - особых частей тела, состоящих из различных тканей и выполняющих определённые функции. Органами растения являются побег и корень. Побег, состоящий из стебля и располагающихся на нём листьев и почек, выполняет основную функцию воздушного питания. В листьях происходит фотосинтез, процесс образования органических веществ. Важнейшие функции корня - удерживание растения в почве (якорная функция), поглощение из нее минеральных веществ и воды и синтетическая (в нём образуется ряд веществ, таких как алкалоиды, гормоны роста). Кроме того, как у побега, так и у корня имеется ряд дополнительных функций, характерных далеко не для всех растений или проявляющихся лишь в особых обстоятельствах. Например, для корня - это участие в вегетативном размножении и запасание питательных веществ. Интересную роль выполняет корень рясок из одноимённого семейства - он играет роль противовеса, не позволяя переворачиваться этим миниатюрным плавающим растениям при волнении воды.

Иногда второстепенная функция становится определяющей. В таких случаях происходит изменение строения органа. Если оно сохраняется в последующих поколениях, следовательно, как мы уже говорили, произошло видоизменение, или метаморфоз.

Во флоре Приморья растений с видоизменёнными органами достаточно много. При этом метаморфозу подвергаются не только корни и целые побеги, но также отдельно листья. С одними из видоизменений, колючками, мы познакомились выше. Сейчас речь о других.

Все видоизменения лучше рассмотреть с точки зрения функции, которую они выполняют.

\section{«Закрома» растений}

Любому живому организму необходим определённый запас питательных веществ, которые можно экономно расходовать в стрессовых условиях. Пытаясь создать надежный «банк» для хранения этих веществ, растения научились менять строение своих органов.

У растений Приморья подобными «кладовыми» являются корневые шишки, корневища, клубни, луковицы и клубнелуковицы. Это подземные образования, в которых накапливаются органические вещества (главным образом крахмал) для последующего развития надземных частей. Следует отметить, что видоизменения с запасающей функцией нередко используются для расселения растений (о путях расселения мы поговорим в отдельной главе) и вегетативного размножения. 
Большая часть перечисленных видоизменений имеет побеговое происхождение, лишь корневые шишки являются метаморфозами корней.

Нужно сказать, что в любом корне имеется некоторый запас питательных веществ, расходуемых растением на разнообразные процессы жизнедеятельности. Однако у целого ряда видов запасающие ткани получают преимущественное развитие, и корни при этом формируются довольно толстые. Такие корни встречаются у представителей многих семейств (Колокольчиковые, Молочаевые, Сельдереевые, или Зонтичные, и др.), и нередко их можно спутать с корнеплодами или корнеклубнями. Так, утолщённый корень имеется у женьшеня из семейства Аралиевые. У многих водно-болотных растений корни внешне также кажутся утолщёнными. Это связано с тем, что внутри корня, в его коре, развивается мощная воздухоносная ткань, так как корни этих растений испытывают недостаток кислорода. А утолщение главного корня многих каучуконосов, например, одуванчика (семейство Астровые), происходит за счет формирования большого числа млечников. У хохлатки гигантской из семейства Маковые, произрастающей в Приморье по берегам рек и ручьев, главный корень может достигать 80 сантиметров длины и 6 сантиметров в диаметре!

У некоторых растений развитие запасающей ткани наследственно закрепляется. Во флоре Приморья нет растений с видоизменённым главным корнем, и метаморфозу подвергаются корни боковые или придаточные, которые, накопив питательные вещества, разрастаются и утолщаются. У таких корней рост в длину и поглощающая способность, как правило, подавлены, поэтому растения имеют и обычные, не видоизменённые корни. Утолщённые участки носят название корнеклубней, или корневых шишек.

Растения с корневыми шишками встречаются в нескольких семействах: Лютиковые, Гвоздиковые, Толстянковые и ряда других.
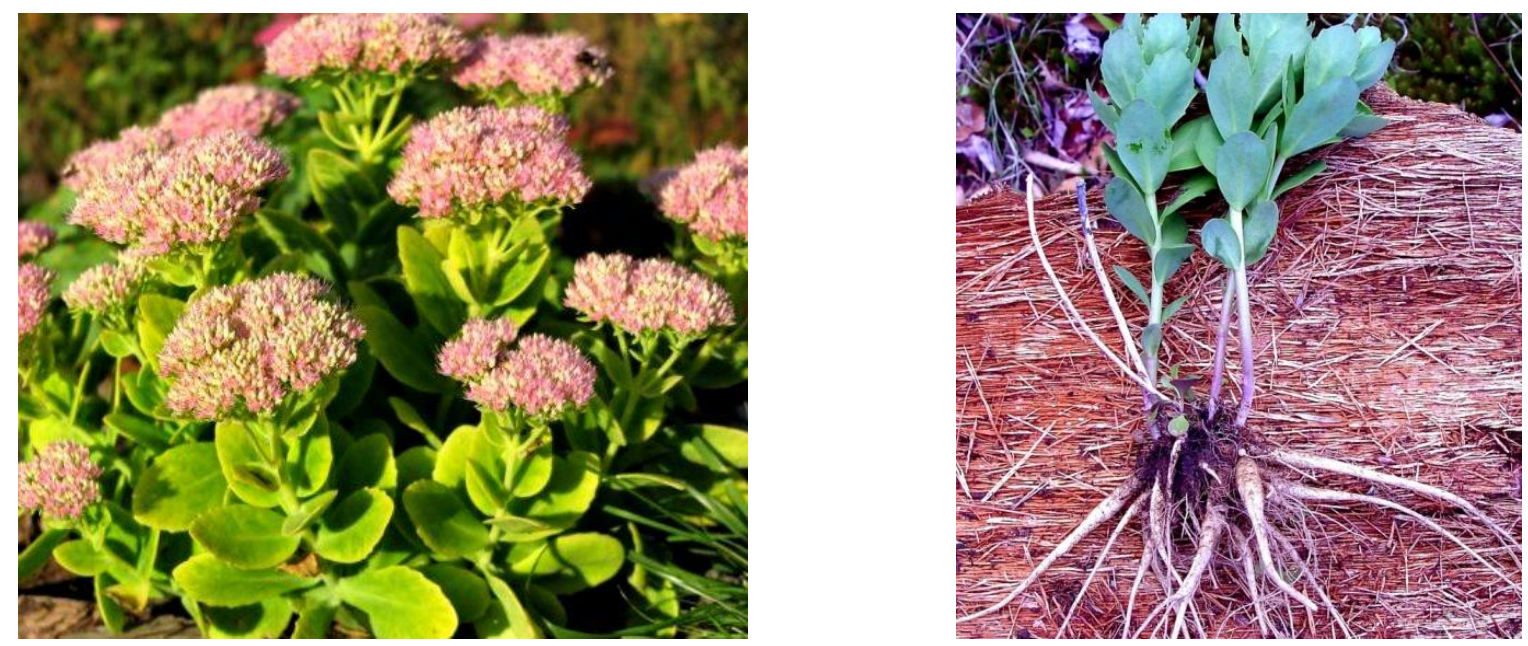

Очиток заячья капуста (https://fermoved.ru) и его корнеклубни (https://newfs.s3.amazonaws.com)

Из лютиковых корнеклубни имеются у двух видов василисника - клубненосного и тычиночного. У первого они цилиндрические, а у второго - округлые. Эти виды составляют особую секцию в роде василисник и представлены травянистыми многолетниками до 4060 см высоты, у которых есть тройчатосложные или дважды тройчатосложные прикорневые листья. Растут они в хвойных и лиственных лесах. Чёрные веретеновидные корнеклубни около сантиметра длиной есть у равноплодника маньчжурского из этого же семейства. При 
этом если у василисников они развиваются в средней части корней, у равноплодника находятся в их основании.

В семействе Гвоздиковые корневые шишки есть у видов звездчаточки и зорьки сверкающей. У последнего вида от вертикального короткого корневища отходит мочка многочисленных корневых шишек, являющихся видоизменениями придаточных корней).

Довольно крупные корневые шишки, до восьми сантиметров длины и двух сантиметров в диаметре, наблюдаются у очитка заячьей капусты из семейства Толстянковые. Они постепенно переходят в тонкие корни.

Корневые шишки имеются и у огневика клубненосного из семейства Яснотковые (Губоцветные). Для Приморья это заносное растение, которое можно встретить у дорог или по железнодорожным насыпям. Общий же ареал растения охватывает Европу, Среднюю и Восточную Азию. Корневые шишки огневика нередко использовали в пищу - в варёном, жареном или печёном виде, готовили из них муку, различные кондитерские изделия и каши. В Калмыкии порошок корнеклубней применяли для приготовления целебного чая.

У представителя семейства Крапивовые, довольно высокого, до полутора метров, однолетника лапортеи клубненосной, растущей по берегам лесных ручьев, в основании стебля образуются веретенообразные корнеклубни.

Нередко питательные вещества запасаются в корневищах. Корневище - это тот же побег, но подземный. Оно также состоит из узлов и междоузлий, часто имеются и листья, но, конечно, они очень мелкие, видоизменённые, чешуевидные. В узлах часто образуются придаточные корни. Корневища отличаются направлением роста, длиной междоузлий, способом образования, толщиной. Утолщены как раз корневища, выполняющие запасающую функцию.

В Приморье корневищные растения принадлежат отделам Хвощевидные, Папоротниковидные, Покрытосеменные. Отсутствуют они у голосеменных растений, встречаются, хотя и нечасто, у представителей отделов Моховидные и Плауновидные.

Корневища, служащие преимущественно для накопления питательных веществ, имеются у растений родов купена, смилацина (семейство Ландышевые), башмачок (семейство Орхидные) и др. У видов бодяка из семейства Астровые на коротком утолщённом корневище ещё развиваются клубневидно утолщённые одревесневающие мочки.

Для накопления питательных веществ растения могут формировать специфические подземные побеги - столоны. В отличие от корневищ они недолговечны, на них не формируются придаточные корни, а листья редуцированы в еще большей степени. Сами столоны не накапливают питательные вещества, это делает верхушечная почка, которая, сильно разрастаясь, образует клубень. В нём-то и откладываются запасные вещества.

Типичный пример такого растения - картофель, выращиваемый по всему миру. По своему строению клубень столонного типа является утолщённым стеблем, состоящим, как и любой стебель, из узлов и междоузлий, но они практически неразличимы. В узлах располагаются почки, которые обычно называют глазками. Клубень - филогенетически молодой орган, появившийся как специфическое приспособление к вегетативному размножению. При этом, вероятно, наиболее часто он возникал у растений среднего горного пояса, особенно в формации горных ксерофитов, которые росли на бедных щебнисто-каменистых почвах. Укороченная клубневидная форма побега возобновления, при отсутствии главного корня, явилась формой, наименее подверженной повреждениям и наиболее приспособленной к условиям подвижного субстрата. В горных районах чаще встречаются клубневые виды (виды хохлатки, очитка, молочая, герани). Такие клубни существуют лишь от одного вегетационного периода до другого, полностью отмирая после расходования накопленных веществ. 
В Приморье клубни столонного происхождения имеются у седмичника европейского (семейство Первоцветовые), стрелолиста трилистного (семейство Частуховые), двулепестников альпийского и стеблеватого (семейство Кипрейные). Есть они и у культивируемого североамериканского растения топинамбура, или земляной груши (семейство Астровые).

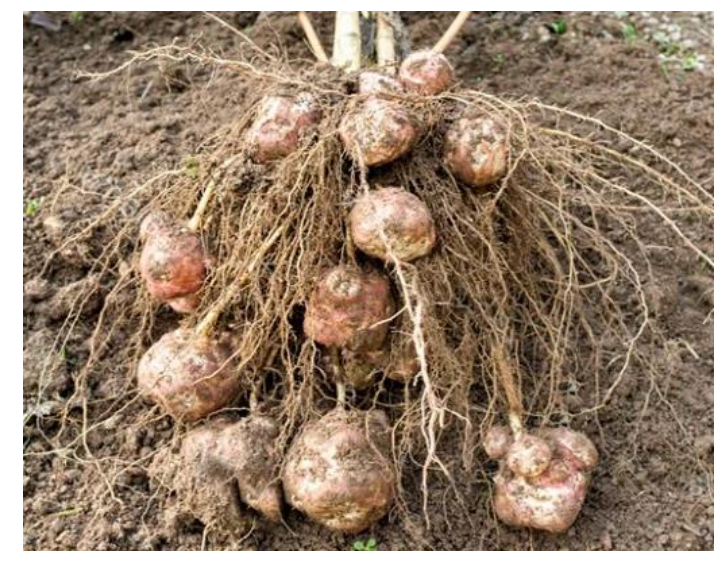

Корнеклубни топинамбура (https://avatars.mds.yandex.net)

У некоторых растений развиваются клубни, являющимися результатом утолщения корневищ. В этом случае сами утолщения имеют более или менее шарообразную форму, поэтому они тоже называются клубнями. Как и столонные клубни, они существуют лишь один год. Свойственны представителям семейств Сытевые (Осоковые), Ятрышниковые, Норичниковые, Пионовые, Кувшинковые и др.

Из сытевых Приморского края утолщённые корневища имеются у видов родов камыш и особенно клубнекамыш. Наиболее крупные клубневидные утолщения, до 3 см в диаметре, имеются у клубнекамыша Ягара и клубнекамыша Десулави, встречающихся в Приморье по заболоченным лугам, по берегам зарастающих озер. У стеблелиста мощного из семейства Барбарисовые имеется клубневидно разрастающееся корневище, крупное, узловатое, с немногочисленными корнями. Боковые оси корневища клубневидно утолщаются у двулепестника альпийского из семейства Барбарисовые. Мощные горизонтально расположенные клубневидные корневища имеются у произрастающей на юге Приморья древесной лианы пуерарии лопастной из семейства Бобовые. Это очень быстро растущее растение - годичные побеги могут достигать в длину пятнадцати метров! Чёткообразно утолщённые корневища имеются у шлемника чётковиднокорневищного из семейства Яснотковые.

Клубни могут возникать в самом основании стебля. В этом случае в их формировании принимают участие главным образом гипокотиль (часть стебля от корневой шейки до места отхождения семядольных листьев). В отличие от предыдущих типов эти клубни являются многолетними.

Из растений Приморья с клубнями гипокотильного типа можно назвать весенник звёздчатый (семейство Лютиковые). Клубень у этого раннецветущего лесного растения шаровидный, до двух сантиметров в диаметре, от него отходят придаточные корни. Овальный или шаровидный клубень имеют виды рода хохлатка (семейство Маковые) - их клубни в среднем около сантиметра в диаметре. Клубневидными корнями обладают представители семейства Колокольчиковые ширококолокольчик крупноцветковый и виды колокольника.

Весьма интересными образованиями обладает сердечник трёхнадрезанный из семейства Капустовые, или Крестоцветные. От корневища на тонких нитевидных черешках распо- 
лагаются листья, видоизменившиеся в небольшие беловатые уплощённые клубеньки до 0,8 сантиметра длины и 0,6 сантиметра ширины, на верхушке трёхзубчатые.

На очереди еще одно видоизменение с запасающей функцией - луковица. В отличие от предыдущих метаморфозов, в луковице питательные вещества запасаются не в стебле, а в листьях - вспомните обычный репчатый лук. Как видоизмёненный орган луковица приспособлена к климату средиземноморского типа - с мягкой и теплой влажной осенью, достаточно мягкой зимой и с очень жарким и засушливым летом. Она служит главным образом для переживания жёсткой летней засухи. Встречаются луковичные растения также в степях, полупустынях, некоторых пустынях, а также в широколиственных лесах.

Во флоре Приморья луковичных растений не очень много, они относятся к семействам Лилиевые и Луковые.

Луковицы имеют различное строение. В одних случаях чешуи, которые являются видоизменёнными листьями, срастаются краями и полностью охватывают внутренние чешуи (как у репчатого лука), так что кажется, будто они вложены друг в друга. Такие луковицы называются туникатными. Они свойственны рябчикам, лукам. В другом случае чешуи не срастаются краями, и охватывают внутренние чешуи лишь наполовину или чуть более (полутуникатные) - например, у пролески. Наконец, у лилий чешуи небольшие, они черепитчато накладываются друг на друга.

Луковица обычно одиночная, но у лилии ложнотигровой имеется длинный подземный стебель, на котором развиваются от одной до пяти дочерних луковиц. У лука крупнотычинкового и лилии ложнопятнистой дочерние луковицы образуются на столонах.

Наконец, последнее видоизменение с запасающей функцией - клубнелуковица. Это переходная форма между типичными клубнем и луковицей. Листовые чешуи клубнелуковицы сухие, а запасные вещества откладываются в стеблевой части. На оси клубнелуковицы хорошо заметны узлы и междоузлия. Клубнелуковицы характерны для таких растений, как гладиолус, шафран (семейство Касатиковые, или Ирисовые), безвременник из одноименного семейства, некоторые амариллисовые. Из растений Приморья клубнелуковица характерна для горноятрышника раскидистого из семейства Ятрышниковые (Орхидные).

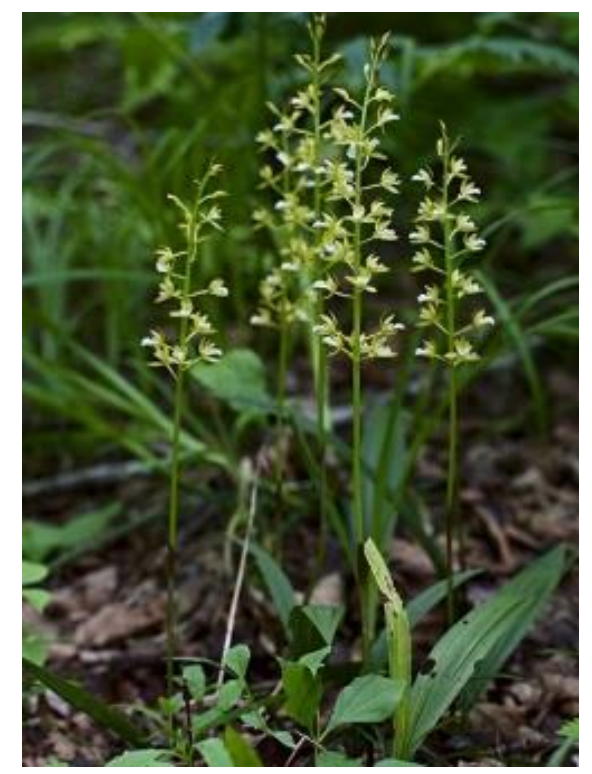

Горноятрышник раскидистый (http://rgo-sib.ru/reportage/858.htm) 
Взрослое растение горноятрышника насчитывает от одного до пяти плотно прилегающих друг к другу клубнелуковиц, от каждой из которых отходят до пяти придаточных корней длиной около 5-6 сантиметров. Интересно, что для них характерен довольно слабый геотропизм - они направлены в разные стороны, иногда даже вверх.

\section{Ты моя защита}

В зоне сезонного климата, в которой находится и Приморье, основную опасность для растений представляют низкие температуры зимнего периода и защищать растению приходится нежные зачатки будущих побегов, находящихся в почках.

Прямую защитную функцию в данном случае выполняют почечные чешуи, которые представляют собой видоизменённые листья; при распускании почек они, как правило, опадают. Свойственны почечные чешуи древесным растениям. У разных видов они различаются своими размерами, числом, формой, интенсивностью опушения, окраской и др. В редких исключениях (свидина белая, калина бурейская) зачаточный побег прикрыт не почечными чешуями, а настоящими листьями, которые весной разрастаются и превращаются в обычные листья.

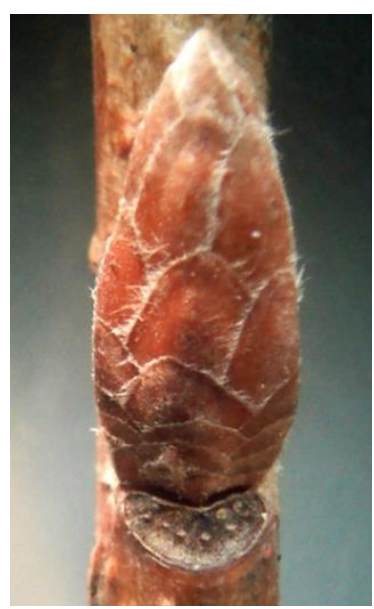

Почка дуба монгольского

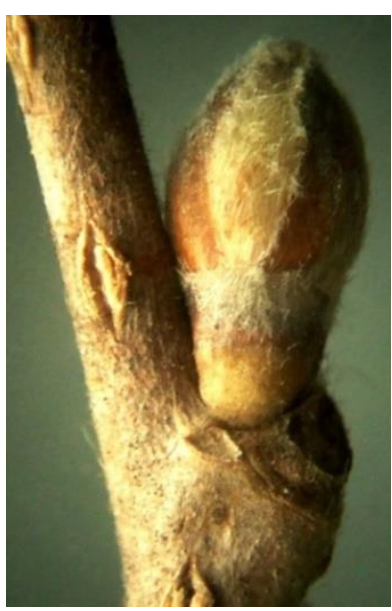

Почка лещины маньчжурской Почка липы амурской

Почки возобновления, находящиеся на подземных органах травянистых растений, также нуждаются в защите. С этой целью многие растения образуют так называемые втягивающие, или контрактильные, корни.

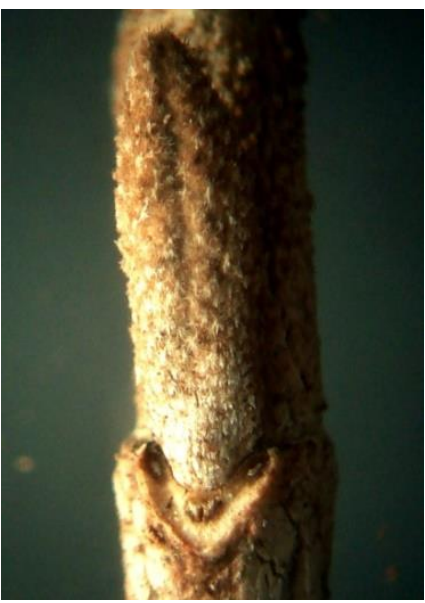

Почка калины бурейской

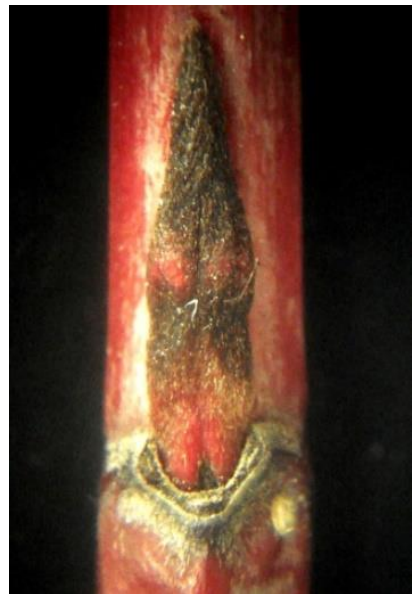

Почка свидины белой 
Они встречаются у многих однодольных и травянистых двудольных растений, главным образом у луковичных и клубнелуковичных растений, чаще всего из семейств Лилиевые, Касатиковые (Ирисовые), Амариллисовые. Это обычно длинные, неветвящиеся, крепкие, утолщённые и мясистые корни. Они растут вертикально вниз и лишены корневых волосков. Клетки контрактильных корней содержат много глюкозы, но когда к осени ее количество снижается, кора становится дряблой и сжимается в ряде поперечных участков, вследствие чего корень укорачивается на 30-40\%. А это, в свою очередь, ведёт к втягиванию подземной части более глубоко в почву. В результате почки возобновления лучше защищены от вымерзания.

Однако следует отметить, что у видов родов спаржа и купена (семейство Спаржевые) эти корни не втягивают растение вглубь, а играют роль якоря, удерживающего растения на месте при сильных ветрах, а у розеточных растений (подорожник большой из одноименного семейства, одуванчик лекарственный из семейства Астровые) контрактильные корни способствуют плотному прилеганию розеток к почве.

Типичные контрактильные корни среди представителей приморской флоры имеются у представителей семейства Лилиевые. Они, как правило, неразветвлённые, беловатые, поперечно морщинистые из-за ежегодного сокращения тканей. На поперечном срезе контрактильного корня лилии пенсильванской видно, что он имеет типичное для корней строение. Интересной особенностью является то, что клетки коры имеют размеры, уменьшающиеся по направлению к центральному цилиндру. В самом центральном цилиндре в центре располагаются пять-шесть клеток ксилемы и четыре участка флоэмы, представленные шестьюсемью клетками.

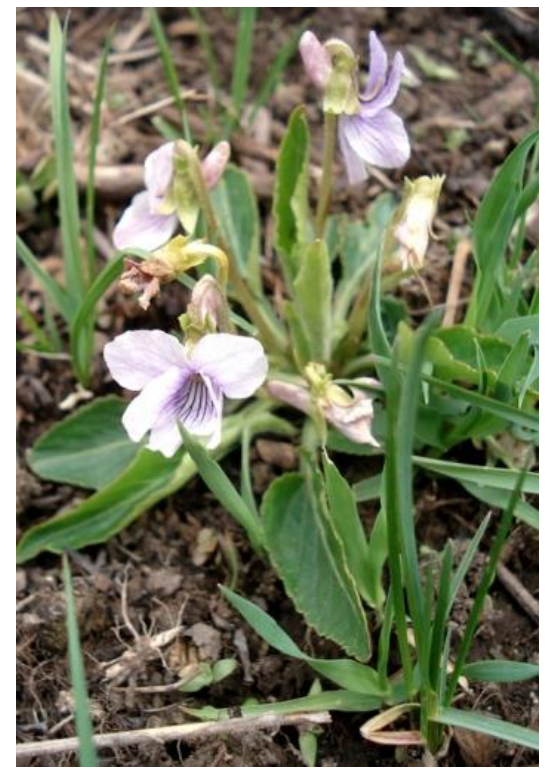

Фиалка холмовая

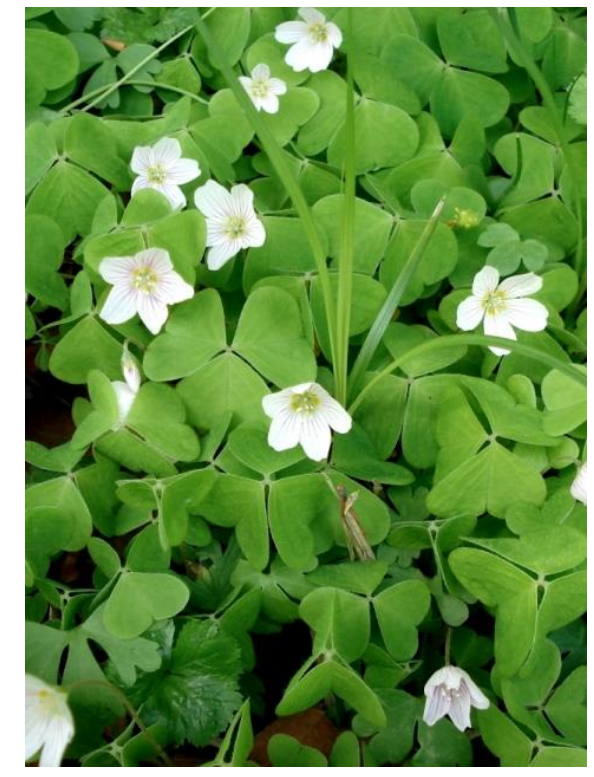

Кислица обыкновенная

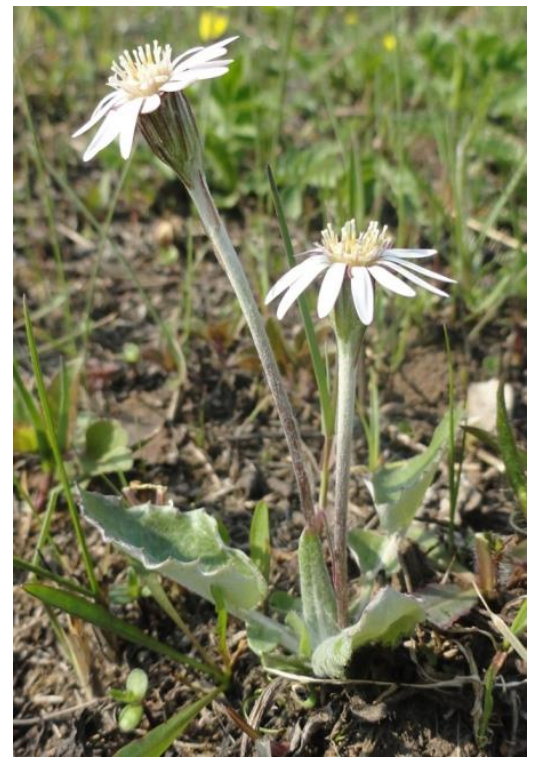

Лейбниция бестычинковая

Наличие контрактильных корней указывается для краснокнижной печёночницы азиатской из семейства Лютиковые, небольшого, до 15 см высоты, травянистого растения с белыми или голубовато-розовыми цветками, растущего на самом юге Приморья в Хасанском и Шкотовском районах. Её корни тонкошнуровидные, многочисленные, отходят от короткого (2-3 сантиметра) тонкого (0,25-0,3 сантиметра) корневища. 
Наконец, определённую защитную функцию выполняют и колючки с шипами, о которых говорилось в предыдущем разделе.

\section{Наличие отсутствия}

Различные органы растений могут редуцироваться (приобретать небольшие размеры) или исчезать совсем. Любому растению необходимо продолжить себя в последующих поколениях, а значит, необходимо формирование генеративных органов (шишек, цветков и др.). Следовательно, побег (а перечисленные образования - видоизменённые в процессе эволюции побеги), пусть даже и в различной степени редуцированный, должен присутствовать обязательно. Хотя он может сильно измениться, значительно уменьшив какие-то свои составные части - стебель или лист.

Например, существует группа так называемых бесстебельных растений. Названы они так потому, что их стебель сильно укорочен и визуально зачастую незаметен, а листья располагаются в т.н. розетке, из которой выходят один или несколько цветоносов.

В Приморском крае к этой группе растений относятся представители более чем пятнадцати семейств. Из самых знакомых это фиалки, подорожники, шерстестебельники, красодневы, кислицы из одноимённых семейств, а также земляника восточная и вальдшейния тройчатая из семейства Розовые, одуванчик и лейбниция из семейства Астровые и целый ряд других растений.

В некоторых случаях сильно редуцируются листья. Так, у спаржи, которая относится к одноименному семейству, листья есть, но они очень мелкие, усохшие, принявшие вид чешуек. В Приморье встречаются два вида спаржи - шобериевидная и менее распространённая маловетвистая. От стеблей спаржи отходят тонкие зелёные отростки, которые, однако, являются не листьями а видоизменёнными побегами. Ботаники называют такие листоподобные побеги особым термином - филлокладии. Филлокладии спаржи шобериевидной зелёные, игольчатые, трёхгранные в поперечном сечении, около двух сантиметров длины и до миллиметра ширины. Располагаются они на стебле в мутовках по три, причём расположение в узле специфическое: обычно два филлокладия расположены по одной прямой, а третий - перпендикулярно им.

А есть растения, у которых листьев вовсе нет. Это виды повилики из одноимённого семейства. Поскольку в листьях происходит фотосинтез - главный поставщик органических веществ, следовательно, повиликам нужно найти другой их источник. И они пошли самым простым путём - начали отбирать их у других растений. То есть повилики являются паразитическими растениями, причём облигатными паразитами, которые от своих хозяев получают не только органику, но и минеральные вещества.

Иногда происходит утрата черешка - такие бесчерешковые листья называются сидячими. Они встречаются у представителей семейств Яснотковые (виды живучки, шлемника), Астровые (одуванчик), Горечавковые (виды золототысячника, горечавки, офелии), Мареновые (виды подмаренника и шерардия полевая), Омеловые (омела окрашенная), лобелии сидячелистной (семейство Колокольчиковые), многих мятликовых и других.

Теперь перейдем к корню. Если растение оказывается в среде, откуда может черпать минеральные вещества и воду всей поверхностью тела, значит, необходимость в корне отпадает. Такой средой может быть только вода. И действительно, некоторые водные растения, полностью погруженные в воду, утрачивают корни. Вспомним, например, элодею, широко выращиваемую в аквариумах. Нет корней и у другого водного растения - альдрованды пузырчатой из семейства Росянковые, обитающей в стоячих водах Приморья. А если корни и 
есть, то могут отсутствовать корневые волоски, как это наблюдается у кувшинки четырёхгранной из одноимённого семейства.

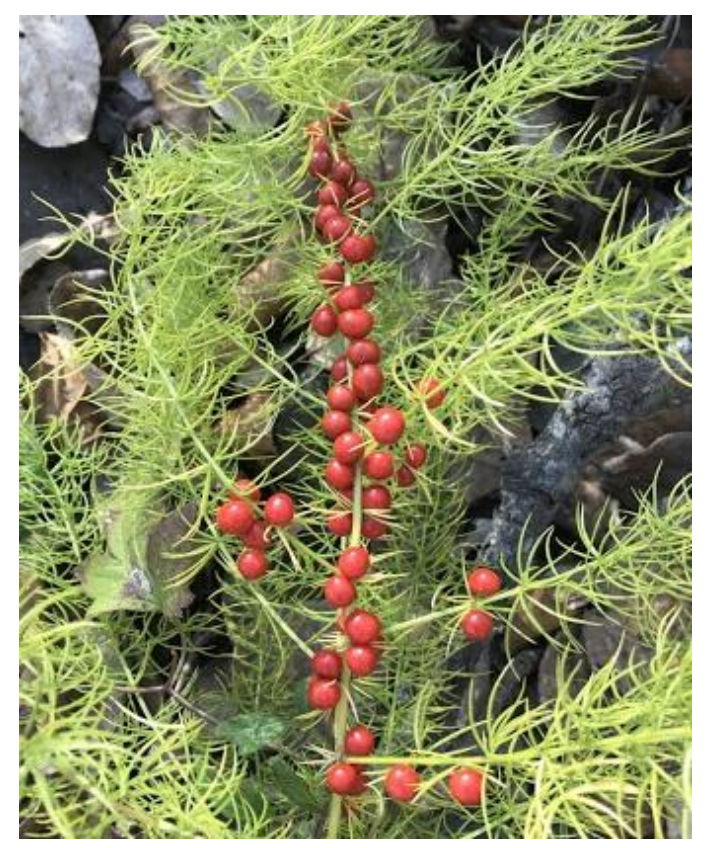

Спаржа шобериевидная (https://lh3.googleusercontent.com)

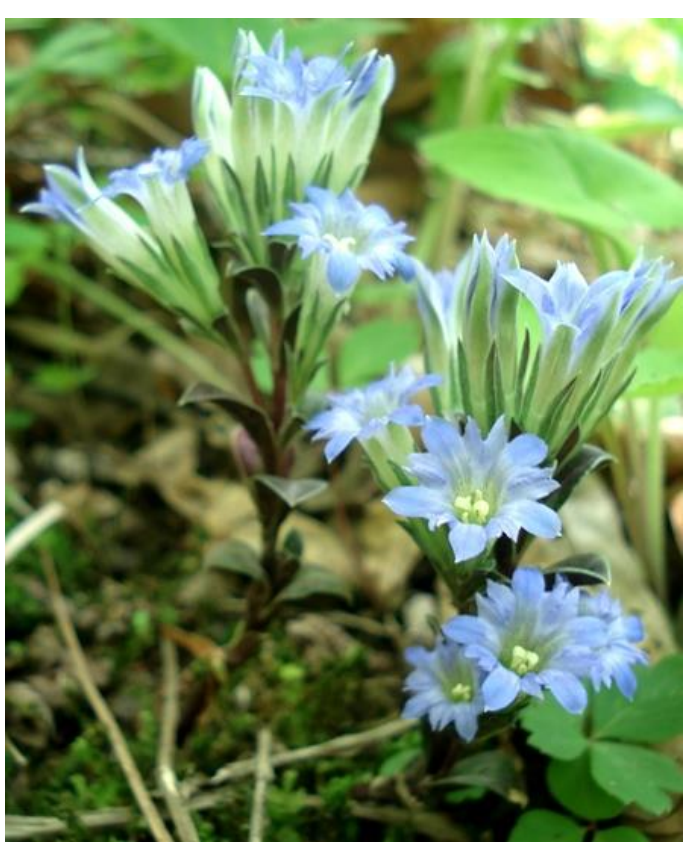

Горечавка Цоллингера

Впрочем, и у некоторых наземных растений могут отсутствовать корни. Это, например, только что упоминавшиеся виды повилики. Как только семя проросло, проростку необходимо найти растение-хозяина, на что должно быть затрачено до десяти, иногда более дней. Если подходящий хозяин найден, повилика прикрепляется к нему своими придаточными корнями, а главный корень отмирает. В случае же, когда по тем или иным причинам подходящий кандидат не будет обнаружен, растение погибает.

Настал черёд генеративных органов. К ним относятся цветки, плоды, семена и шишки. Из школы известно, что цветок - характерный орган цветковых (покрытосеменных) растений, следовательно, он отсутствует у представителей отделов Моховидные, Плауновидные, Хвощевидные, Папоротниковидные, Голосеменные. Шишки как генеративные органы имеются у голосеменных растений.

Остановимся подробнее на генеративных органах покрытосеменных. Цветки этих растений могут быть либо одиночными, либо собранными в соцветия.

Одиночные цветки имеются у представителей лютиковых (видов княжика, ломоноса, прострела, печёночницы азиатской, весенника звёздчатого и др.), диапенсии обратнояйцевидной (семейство Диапенсиевые), белозора болотного (семейство Белозоровые), повоя даурского (семейство Вьюнковые), мака амурского (семейство Маковые), пионов обратнояйцевидного и горного (семейство Пионовые), и ряда других.

Сам цветок состоит из цветоножки, цветоложа, околоцветника и генеративных частей, причём какие-то из этих составных частей могут отсутствовать.

Сидячие цветки, без цветоножки, имеются у подорожника из одноимённого семейства, большинства астровых (сложноцветных). 
Целый ряд растений опыляется с помощью ветра. А значит, привлекать насекомых им нет необходимости, следовательно, и яркий околоцветник им ни к чему. Да и вообще околоцветник, он только мешает ветру. Околоцветник отсутствует у представителей мятликовых, сытевых, ивовых.

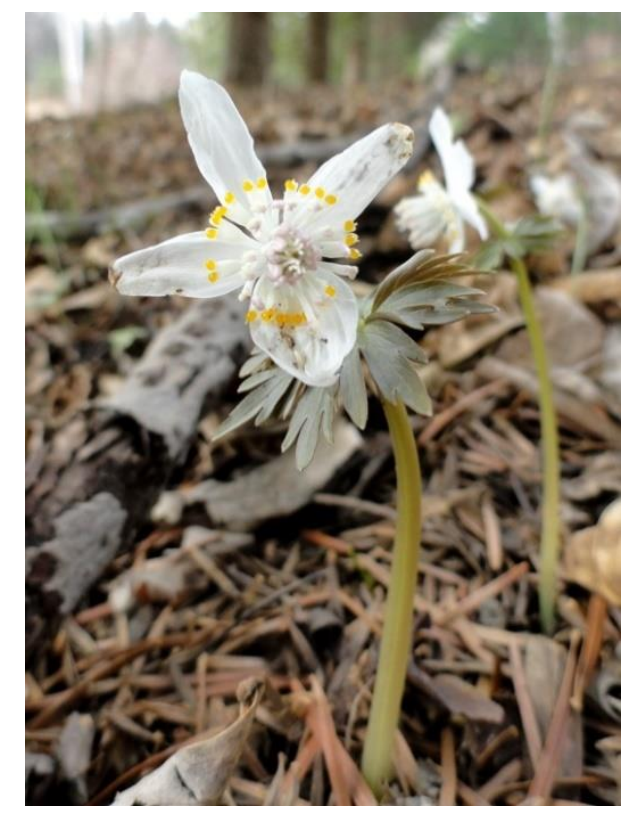

Весенник звёздчатый

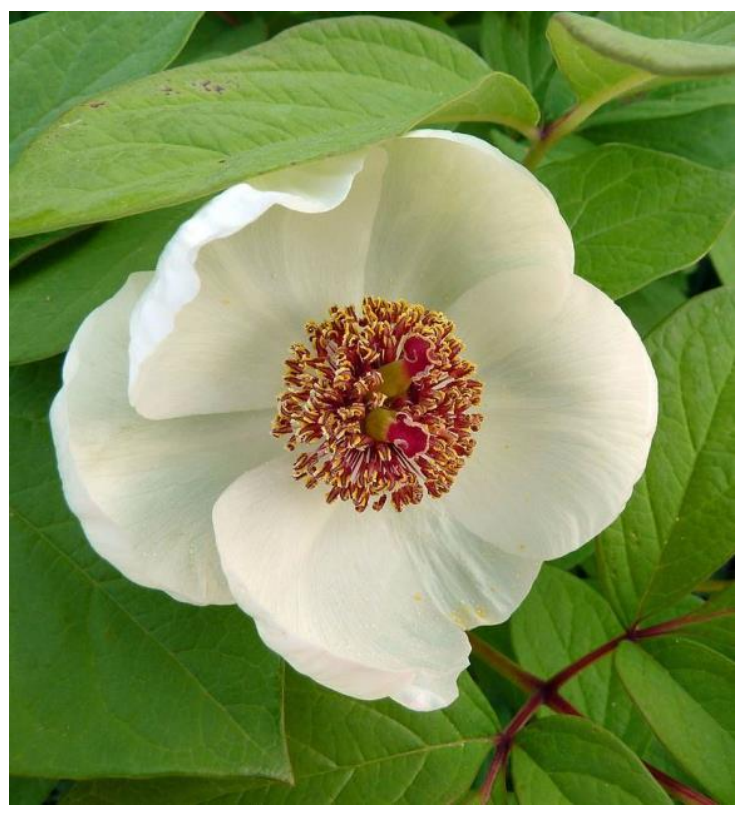

Пион обратнояйцевидный (https://ru.wikipedia.org

\section{Кто на свете всех милее?}

Растения, которые используются для оформления открытых ландшафтов и помещений, называются декоративными. Украшая окружение человека, они оказывают на него положительное эмоциональное воздействие.

Декоративность создается за счет самых разных особенностей растений, но на первом месте всё же стоят отличительные особенности листьев, цветков и плодов. Другие признаки (например, тип ветвления) играют в целом меньшую роль.

В Приморье довольно много декоративных растений. Часть из них уже нашла использование в озеленении городов и посёлков, но большинство еще предстоит внедрить в практику ландшафтного дизайна.

Древесных растений с красивой кроной не так много, декоративность да и у них выражена лишь у отдельно стоящих деревьев.

У некоторых голосеменных развивается крона почти строгой геометрической формы, что всегда привлекает озеленителей. У ели аянской (семейство Кипарисовые) она конусовидная, у можжевельника твёрдого (семейство Кипарисовые) - конусовидно-цилиндрическая. Правда, беда можжевельника состоит в том, что если освещение одностороннее, а с противоположной стороны имеется затемнение, то крона формируется однобокой, что несколько снижает эстетический эффект.

Всегда привлекают внимание деревья с поникающими ветвями, формирующими т.н. «плакучие» формы кроны. Это свойственно некоторым ивам из одноимённого семейства вавилонской и белой. Оба вида не являются аборигенными, ива вавилонская имеет ближневосточное происхождение, а родина ивы белой - Кавказ и Малая Азия. Отличить эти виды можно по почкам - у ивы вавилонской они, как говорят ботаники, диморфные, т.е. цветоч- 
ные почки сильно отличаются от вегетативных, прежде всего размерами. А у ивы белой генеративные и вегетативные почки одинаковые.

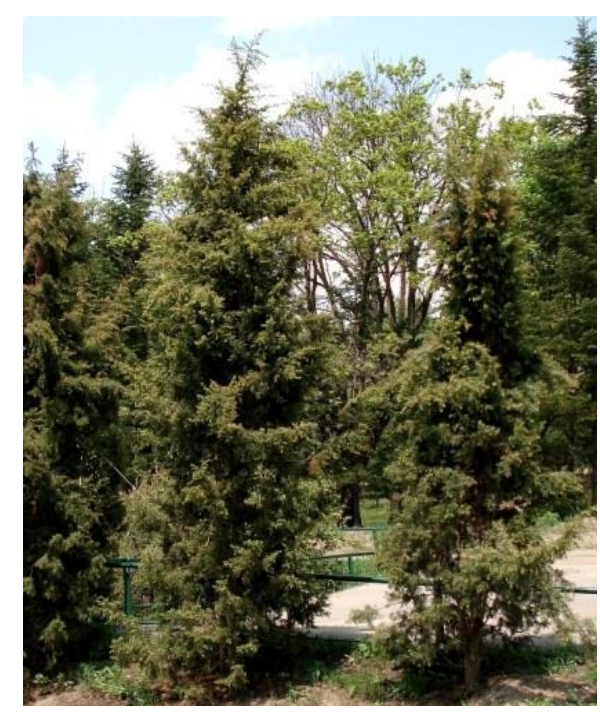

Можжевельник твёрдый

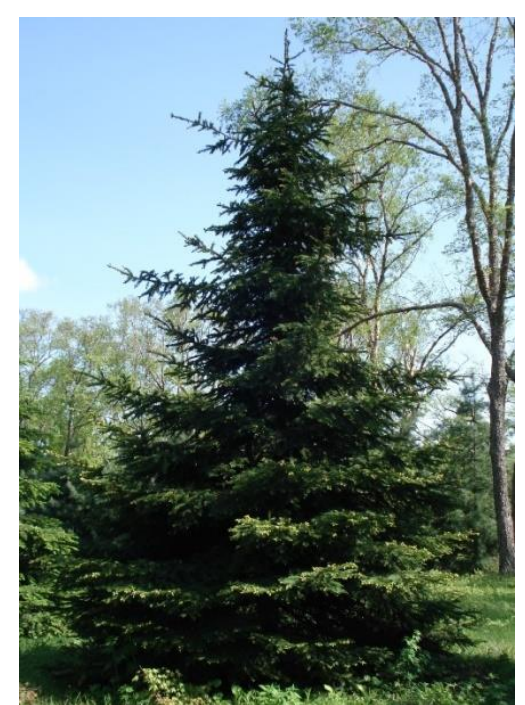

Ель аянская

Крону некоторых древесных растений можно оформлять. Так, легко стрижётся клён приречный, в меньшей степени ильм низкий из одноимённых семейств, из кустарников - пузыплодник калинолистный (семейство Розовые), широко используемый в качестве бордюрного растения.

На декоративность накладывает отпечаток сезонное развитие растений, их декоративные качества меняются вместе с сезонами года. В Приморье мы дважды в год мы радуемся буйству красок природы. Ранней весной она, радуясь приходу тепла, впечатляет нас разноцветьем цветков, раскрашивающих унылый серый пейзаж. Осенью деревья и кустарники последний раз салютуют уходящему лету всеми красками листьев, чтобы вскоре встретить зиму тихим печальным листопадом.

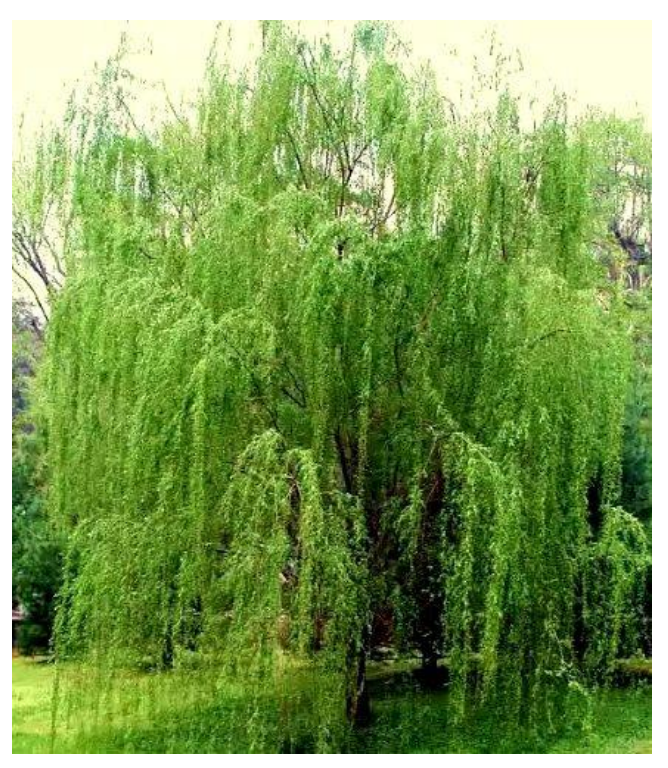

Ива вавилонская (https://gardenstreet.ru)

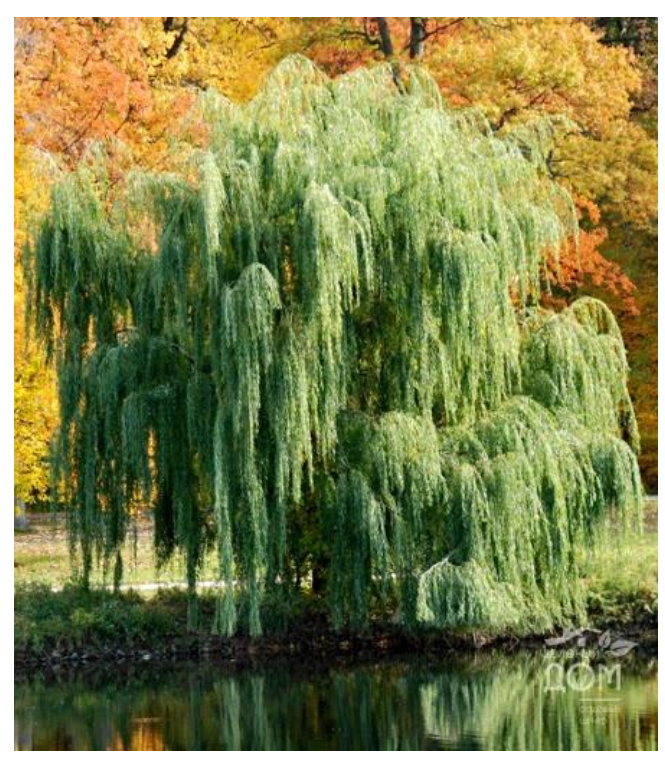

Ива белая (https://h3.googleusercontent.com) 
Среди красивоцветущих видов, которые уже нашли применение в ландшафтном дизайне, можно назвать чубушник тонколистный (семейство Гортензиевые), калину Саржента (семейство Жимолостевые), робинию ложноакациевую, аморфу кустарниковую, караганы древовидную и уссурийскую (семейство Бобовые), трескун амурский, сирень обыкновенную (семейство Маслиновые), грушу уссурийскую, яблоню маньчжурскую, абрикос маньчжурский (семейство Розовые). Реже используются красивейший рододендрон Шлиппенбаха и ряд других рододендронов (семейство Вересковые), лапчатник кустарниковый (семейство Розовые).

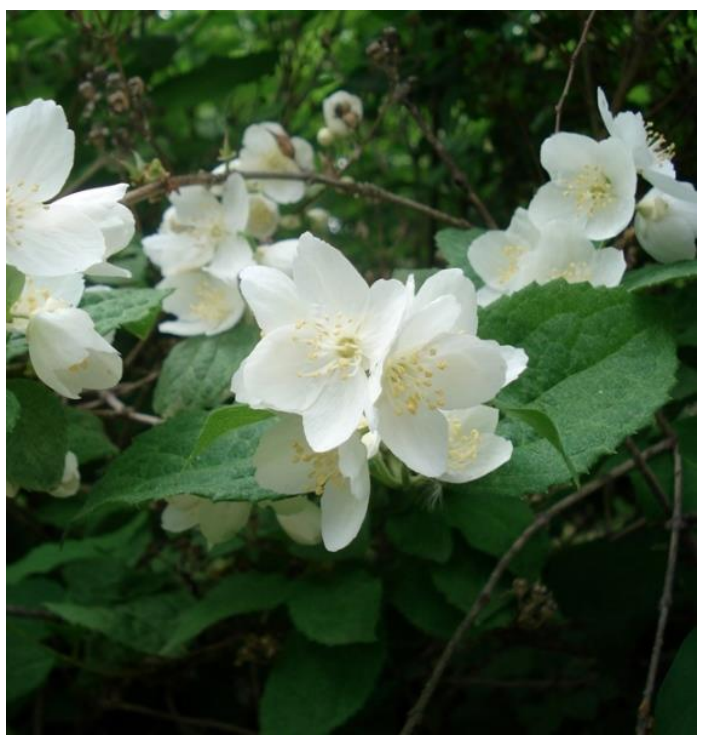

Чубушник тонколистный

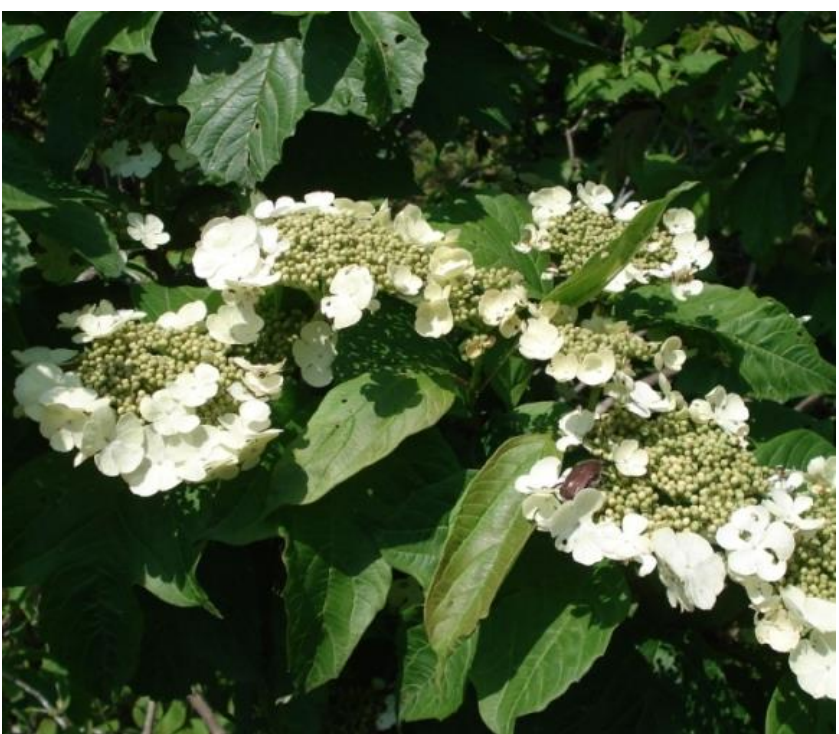

Калина Саржента

Некоторые из растений (робиния, аморфа, карагана древовидная) не являются аборигенными, но из-за широкого распространения упоминаются и во флоре Дальнего Востока.

Довольно много древесных растений, декоративность которым придают листья. Взгляд человека привлекут, например, крупные листья, листья с расчленённой листовой пластинкой или сложные листья, форма пластинки листа, её окраска, наличие опушения и др. Но, как уже говорилось, основное время, когда нас радует листва, это осень, когда листья расцвечиваются разными красками. Об осенней палитре листьев мы и поговорим.

Но для начала вспомним - что же придает растениям окраску? Они обязаны ей особым веществам, пигментам. Так, летом доминирует хлорофилл - важнейший из растительных пигментов, призванный осуществлять фотосинтез, именно он придает листьям зелёную окраску. Кроме хлорофилла в листе имеются и другие пигменты - каротиноиды, играющие в фотосинтезе вспомогательную роль. Одни из них обеспечивают окраску от жёлтой до красной (ксантофиллы), другие оранжевую (каротин). Присутствуют и антоцианы, придающие синюю, красную окраску.

Каким же образом пигменты придают органам определённую окраску?

Глаз человека способен воспринимать видимый спектр - от красного до фиолетового (помните - «каждый охотник желает знать..»). За каждый цвет отвечают фотоны определённой длины волны - за красные 630-760 нм, за фиолетовые 380-440 нм. 


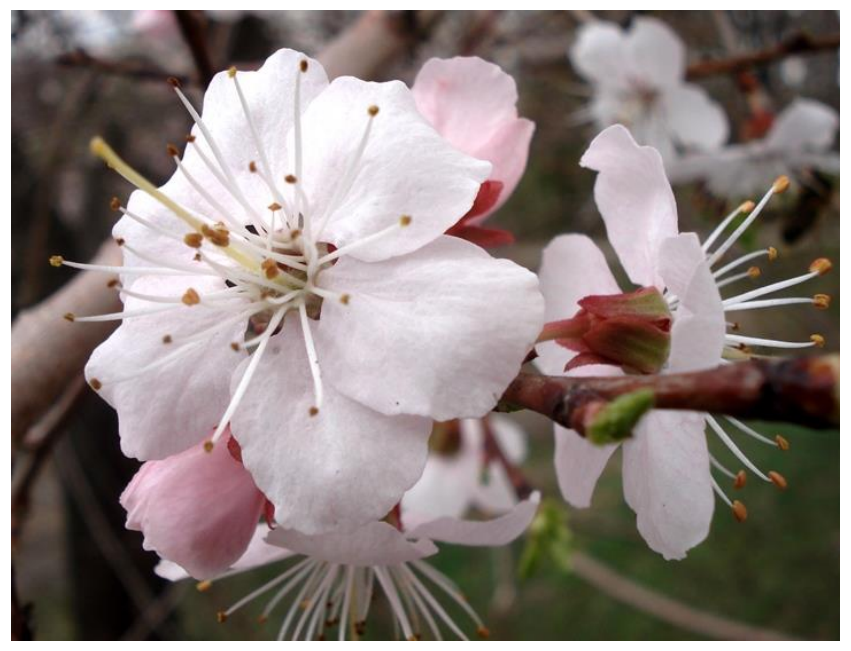

Цветки абрикоса маньчжурского

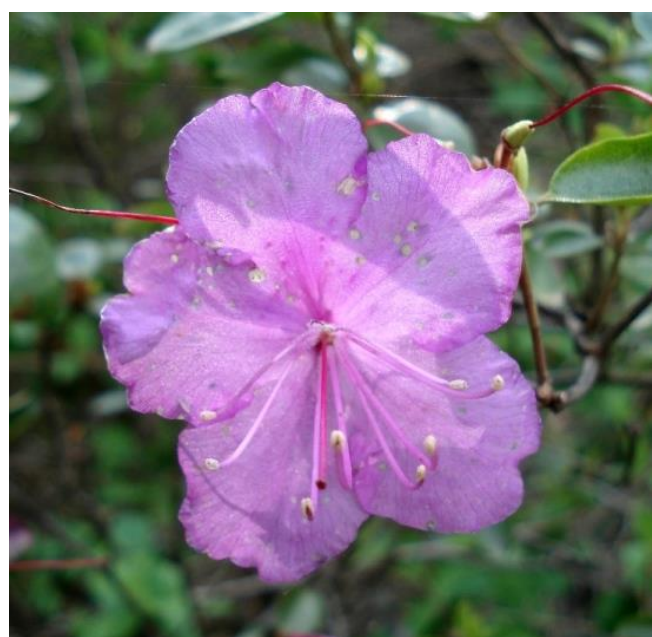

Цветок рододендрона сихотинского

Так вот, пигменты какие-то фотоны поглощают, а какие-то отражают. Отраженные фотоны разной длины волны попадают в глаз человека, где воспринимаются рецепторами сетчатки. При этом обычный человек различит около 100-150 оттенков цветов, профессионал выделит уже до 15 тысяч оттенков, а в идеале человеческий глаз может отличить до миллиона оттенков разной яркости, насыщенности и тона!

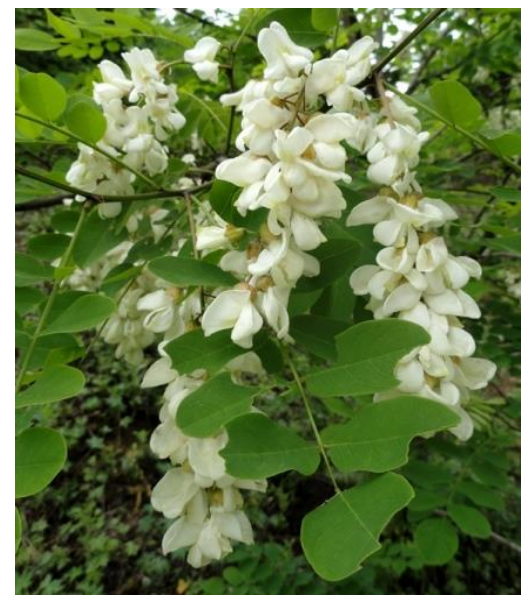

Робиния ложноакациевая

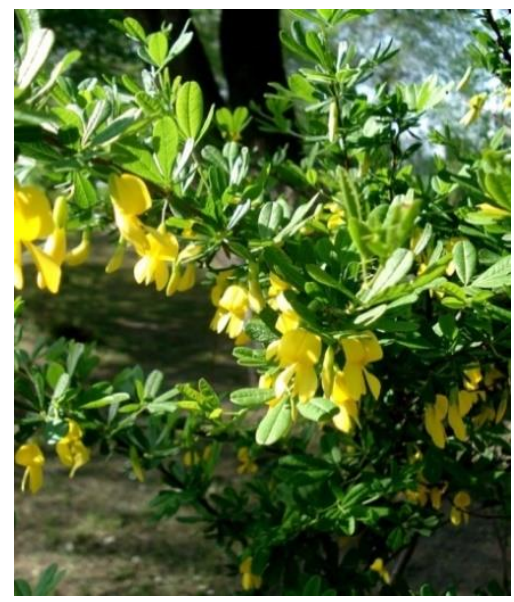

Карагана уссурийская

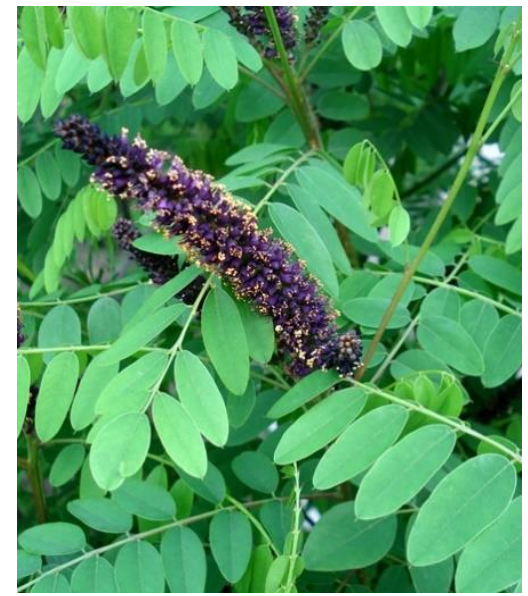

Аморфа кустарниковая

Как известно, в сетчатке глаза есть два основных типа рецепторов - палочки и колбочки. За восприятие цвета отвечают именно колбочки (чувствительные палочки отвечают за сумеречное зрение, но цвета различить уже не могут), три типа которых (воспринимающие фиолетово-синие, жёлто-красные и зелёно-желтые лучи) и обеспечивают узнавание всей цветовой гаммы окружающего мира. Сигнал от рецепторов идёт в зрительные области мозга, где формируется цветовое ощущение. 


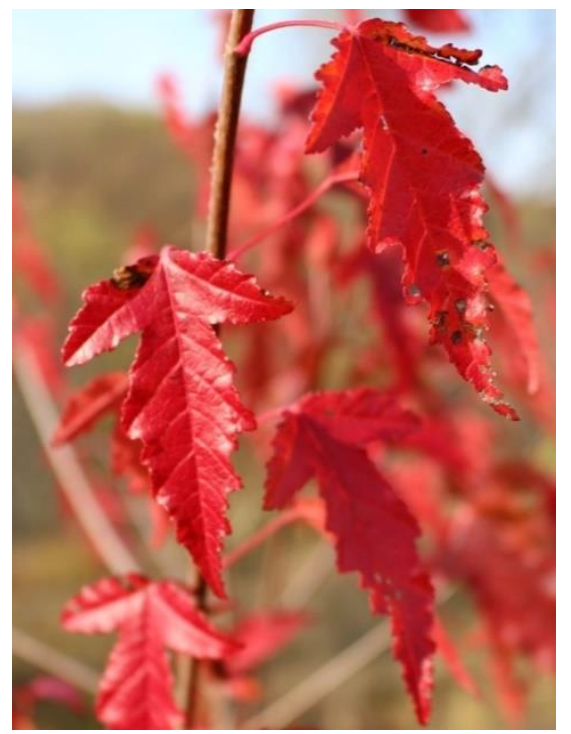

Листья клёна приречного

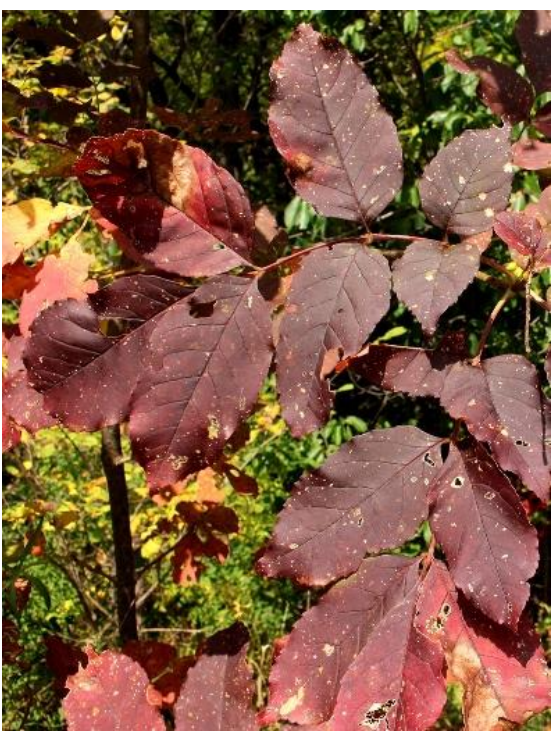

Листья ясеня носолистного

Но вернёмся к растениям. Осенью, когда трудяга хлорофилл разрушается, на первый план выходят каротиноиды, раскрашивая листья в самые разнообразные цвета - от жёлтого до тёмно-бордового. Осенний приморский лес - настоящая палитра красок.

Следует отметить, что в некоторых районах США и Канады развит туризм «созерцания листьев», проводящийся с начала цветовых изменений и заканчивающийся с опадением листьев. Традиционно любование осенним древесным «салютом» и в Японии. Безусловно, такую практику нужно ввести и у нас.

В Приморье осенью обычно господствуют два цвета - жёлтый и красный с разнообразными оттенками. Для разных растений характерен свой определённый спектр окраски. Давайте разберемся, какие растения вносят свой вклад в осеннее разноцветье. Для этого последуем цветам радуги.

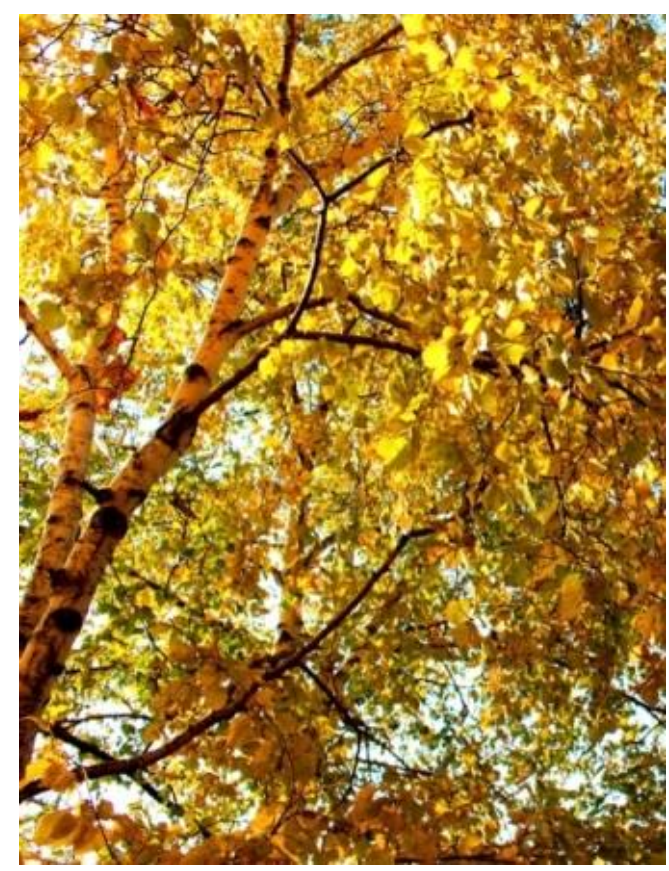

Береза плосколистная

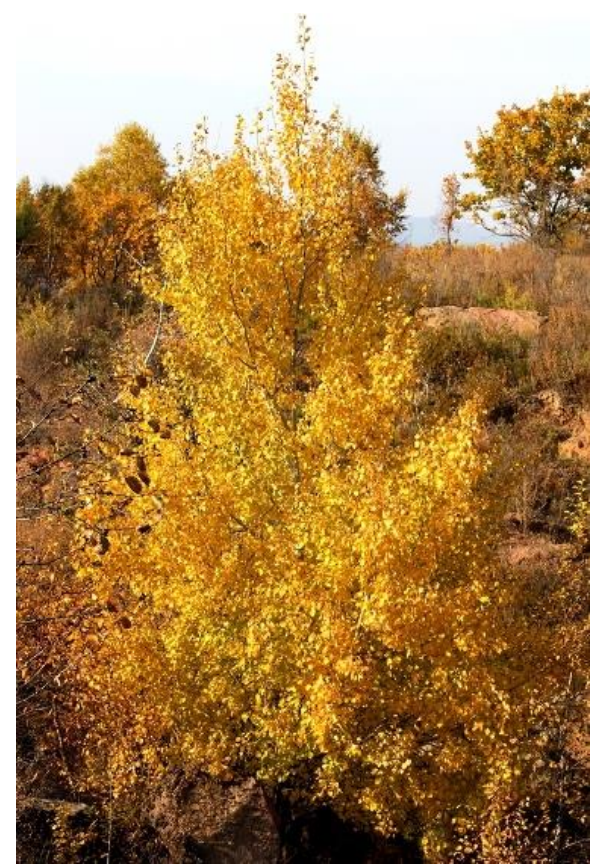

Осина (тополь дрожащий) 
В красный цвет окрашиваются листья винограда амурского (семейство Виноградовые) - он одним из первых расцвечивает свои листья, когда остальные растения еще стоят зелёными. Становятся красными клёны ложнозибольдов, маньчжурский (не каждый год) и клен приречный из одноимённого семейства. Если в солнечную погоду попасть в заросль клёна ложнозибольдова, покажется, что ты оказался посреди бушующего пожара - настолько ярко-красным будет окружение. Окраска листвы в сочетании с её ажурностью делают этот клён одним из самых декоративных древесных растений Приморья. Красноватыми становятся также листья свидины белой из семейства Кизиловые (белой она названа по плодам), бересклета малоцветкового из семейства Берескетовые. Красно-бордовым становится клён приречный, розовым - бересклет малоцветковый, иногда на розовом фоне пластинки листа заметны более тёмные красные пятна, что придаёт им ещё большую декоративность.

Жёлтыми осенью становятся листья осины (семейство Ивовые), калопанакса семилопастного (семейство Аралиевые), бархата амурского (семейство Рутовые), ореха маньчжурского, клёна мелколистного и клёна желтого из одноимённых семейств.

Жёлто-коричневые листья наблюдаются у дуба монгольского (семейство Буковые), мелкоплодника ольхолистного и граба сердцевидного из семейства Берёзовые.

Зелёными довольно долго остаются ольха волосистая (семейство Берёзовые) и робиния ложноакациевая (семейство Бобовые). Последняя в зелёном наряде иногда встречает первые морозы и снегопад.

Процесс разрушения хлорофилла зависит от разных факторов (прежде всего температурного), поэтому осенняя окраска листьев может быть не только однотонной, но и пёстрой. Это наблюдается у дуба монгольского (семейство Буковые), аралии высокой (семейство Аралиевые) и многих других видов.

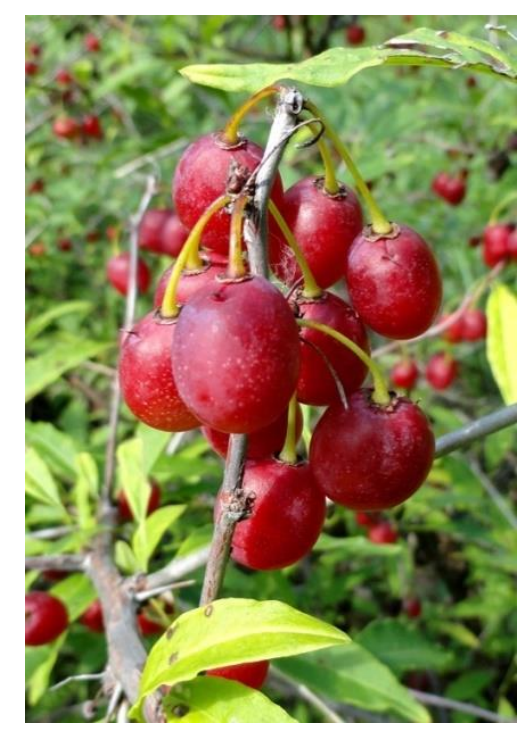

Плоды плоскосемянника

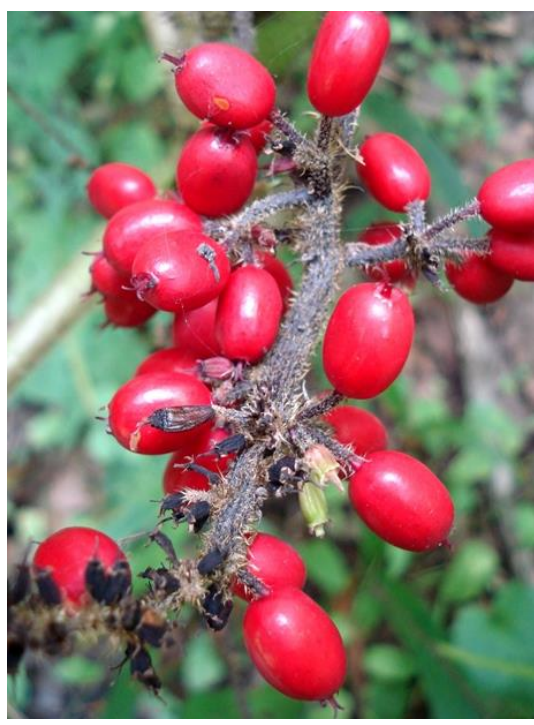

Плоды заманихи высокой

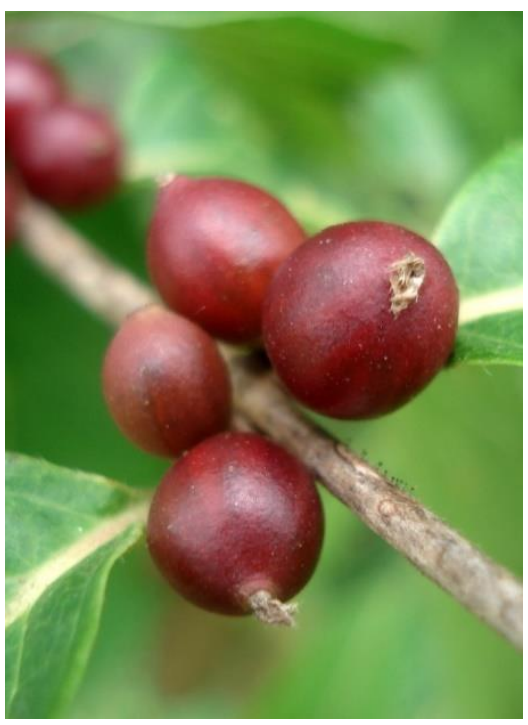

Плоды жимолости Маака китайского

Волны холодного воздуха могут приводить к оригинальной окраске листьев. Так, у абрикоса маньчжурского (семейство Розовые) наблюдаются случаи, когда верх кроны красный, середина жёлтая, а основание кроны - зелёное. Это же наблюдается у клёна приречного. Более того, сами листья могут быть наполовину красные, наполовину жёлтые. Ну кто устоит перед таким великолепием? 

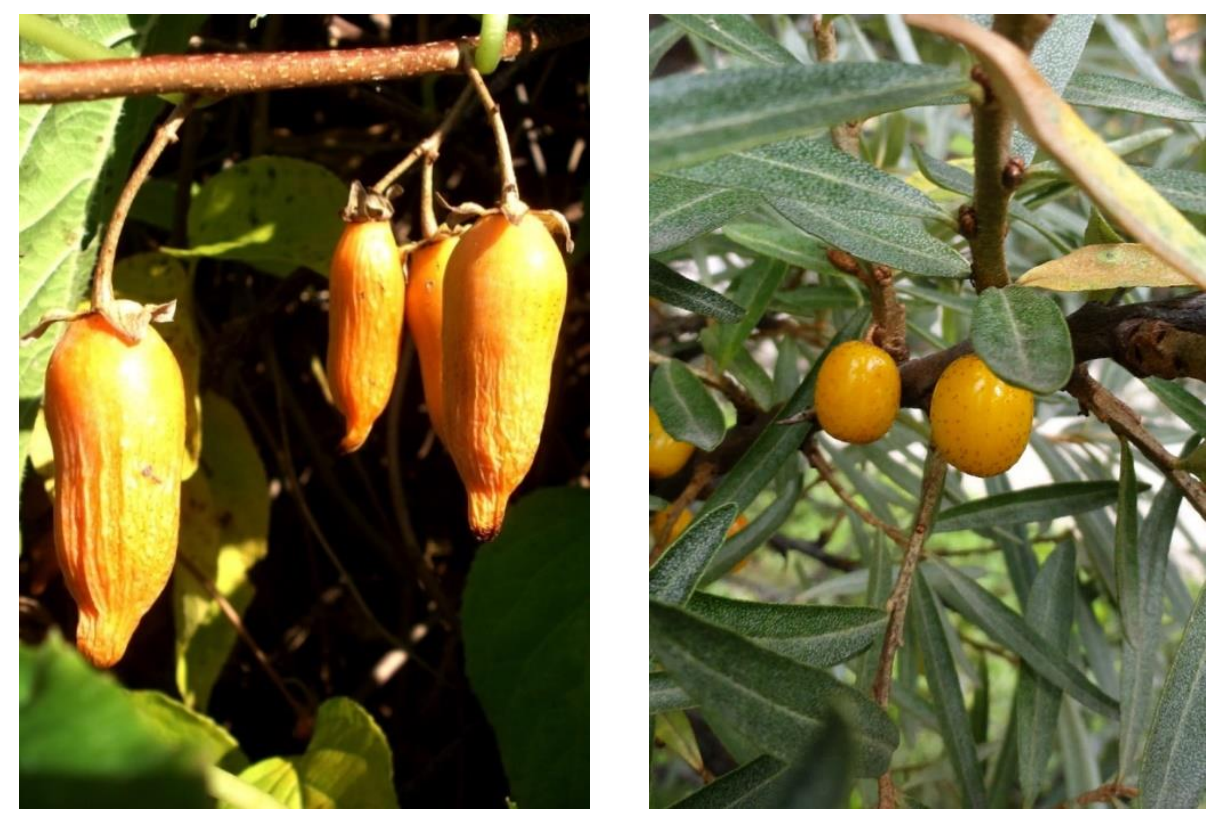

Плоды актинидии многодомной Плоды облепихи крушиновидной

У некоторых растений окраска варьирует. Так, изредка приходилось наблюдать стоящие рядом два клена мелколистных, при этом у одного из них листья отливали жёлтым, у другого были ярко-красными.
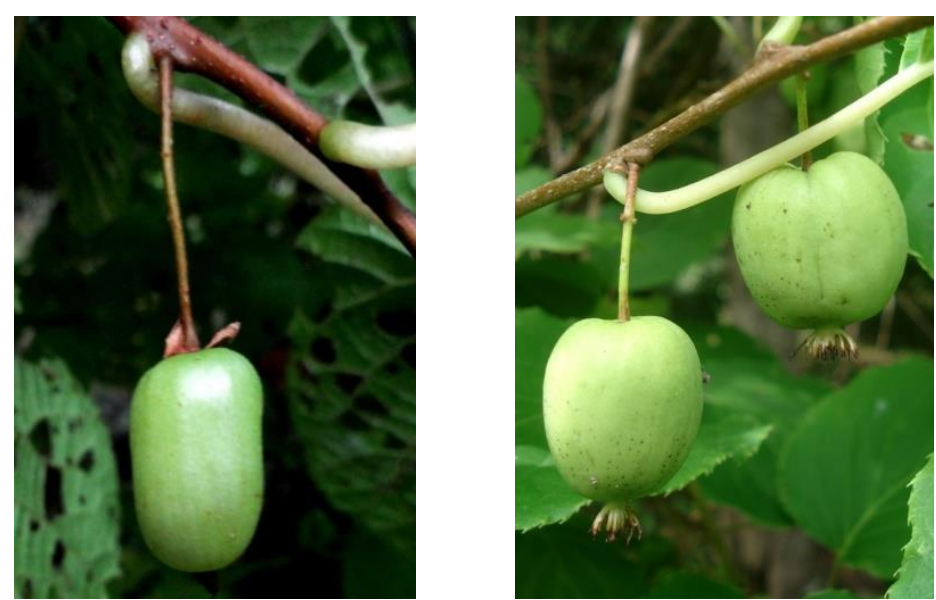

Плод актинидии коломикта Плоды актинидии острой

Однако не только листья вносят свой вклад в осеннее раскрашивание лесов. У большинства древесных растений происходит созревание плодов, а они также бывают самой разной окраски. 


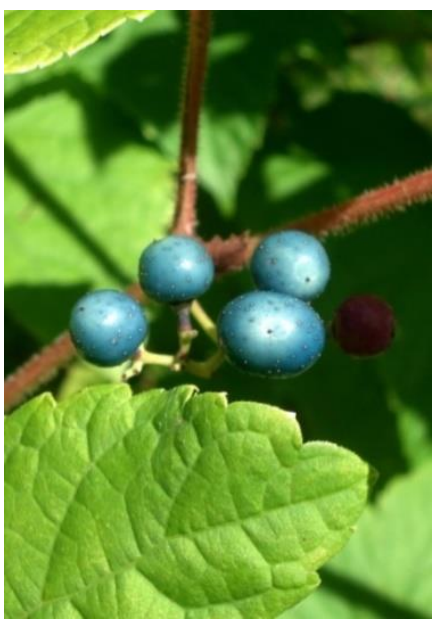

Плоды виноградовника разнолистного

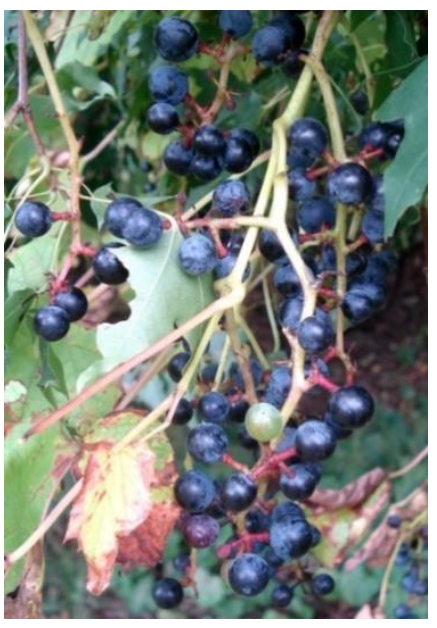

Плоды винограда амурского

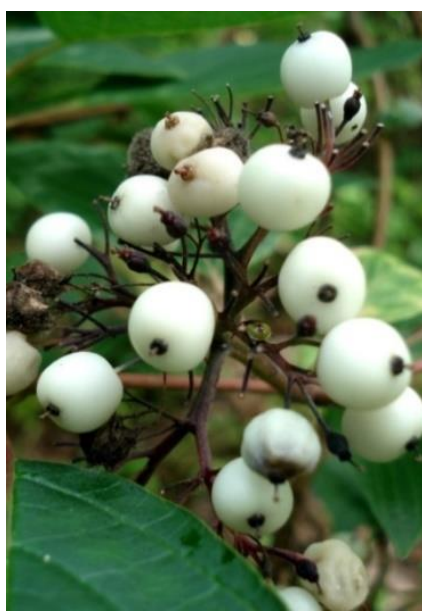

Плоды свидины белой

За окраску плодов земляники, малины, вишни отвечают антоцианы. А если их концентрация очень высокая, плоды становятся визуально чёрными - виноград из одноимённого семейства, ежевика, черёмуха (семейство Розовые).

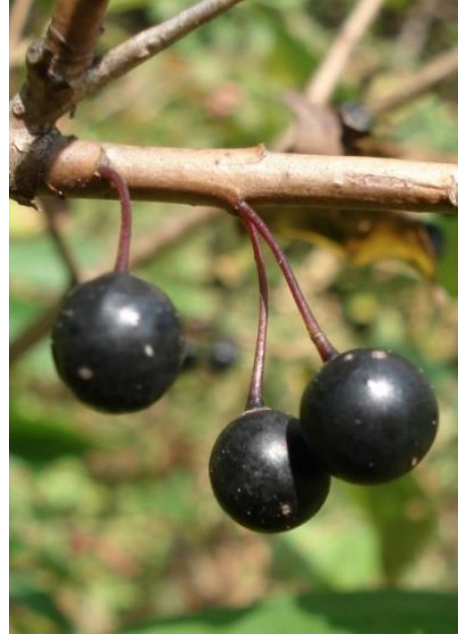

Плоды жёстера уссурийского

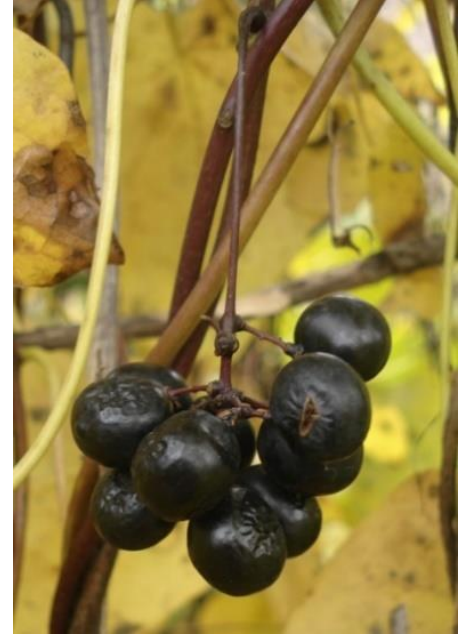

Плоды луносемянника даурского

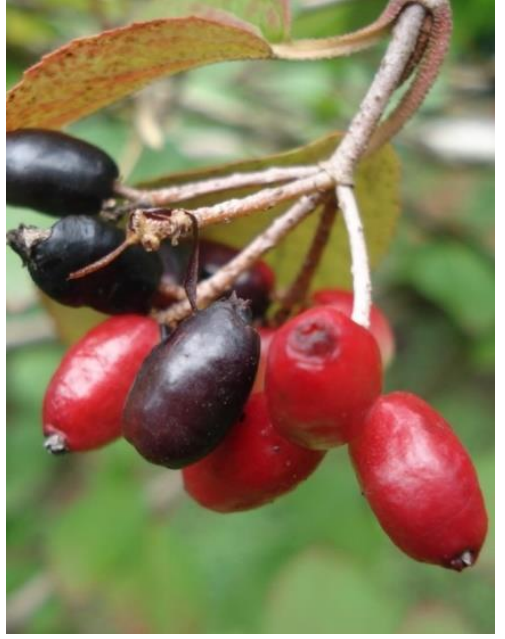

Плоды калины бурейской

Антоцианы можно обнаружить как в генеративных, так и вегетативных органах. Всего известно более 500 различных антоциановых соединений, в основе которых лежит углеродный скелет из 15 атомов углерода. Структура и концентрация антоцианов в органах растений придаёт им окраску от голубого и синего до пурпурно-красного. Уральские селекционеры вывели сорт картофеля «Чудесник» с фиолетовой окраски мякоти, а методами генетической инженерии были получены розы с голубыми цветками и томаты с тёмно-фиолетовыми плодами.

Красные плоды есть у барбариса, видов бузины, лимонника китайского из одноимённых семейств, калины Саржента (семейство Жимолостевые) и др.

Оранжево-жёлтые плоды отмечаются у актинидии многодомной из одноимённого семейства, жёлтые - у облепихи крушиновидной (семейство Лоховые), зелёные - у актинидий 
коломикта и острой, голубые и синие - у виноградовника (семейство Виноградовые), жимолости (семейство Жимолостевые), голубики (семейство Вересковые).

Наконец, чёрные плоды есть у луносемянника даурского, аралии высокой, свободноягодника колючего, а белые - у свидины белой.

Есть в Приморском крае растение, плоды которого меняют цвет трижды. Это калина буреинская (семейство Жимолостевые). Незрелые плоды её зелёные, полузрелые - красные, полностью созревшие чёрные. 
Каждый организм является средоточием самых разных химических веществ. В живых клетках обнаружено присутствие около девяноста элементов таблицы Менделеева (всего их открыто уже более ста пятнадцати), причём роль большинства из них до конца не выяснена. Число же соединений химических элементов в живых организмах вообще не поддается исчислению.

Среди химических веществ клетки преобладают органические соединения, в основе которых лежит углерод - самый распространённый тяжёлый химический элемент во Вселенной. Еще в них входят кислород, водород и азот. Эти четыре элемента составляют около 98\% от химического состава клетки. Неорганические соединения также в ней присутствуют - либо в ионной форме, либо в виде солей, образующих различные конгломераты, например кристаллы.

Химические соединения, содержащиеся в растениях, необходимы им прежде всего для осуществления обмена веществ, являясь во многих случаях его продуктами. Если они при этом накапливаются, становится возможным использование растений и человеком - в пищевых, технических или лечебных целях.

Попробуем же разобраться в тех веществах, которые присутствуют в растениях.

\section{Белки}

Согласно классическому определению Фридриха Энгельса, жизнь представляет собой способ существования белковых тел. По крайней мере, в отношении земной жизни это совершенно справедливо. Организмы, населяющие нашу планету, состоят прежде всего из белков, которые не только строят само тело, но выполняют и другие функции - каталитическую, регуляторную, защитную, а также целый ряд иных, не менее важных.

Так, относительно недавно была выделена особая группа белков, которые образуются в ответ на неблагоприятные воздействия внешней среды и поэтому получившие название стрессовых. Синтезируются эти белки весьма оперативно - уже через несколько часов от начала действия стрессового фактора их содержание может доходить до двух процентов от количества белков, синтезируемых в нормальных условиях. Наиболее изучены так называемые белки теплового шока, образующиеся в результате воздействия повышенной температуры.

Но если растения поместить в холод, то в них также синтезируются стрессовые белки, выполняющие другую, весьма специфическую функцию.

Как известно, организмы получают энергию в процессе клеточного дыхания, которое происходит в особых органоидах - митохондриях. В них молекулы пировиноградной кислоты расщепляются до углекислого газа и воды. В процессе этого распада образуется энергия, которая может либо выделиться в виде тепла (что в норме - бесполезная её трата), либо пойти на образование энергетической «разменной монеты» земных организмов - аденозинтрифосфорной кислоты (АТФ). Молекула АТФ компактна, содержит богатую энергией химическую связь и легко перемещается в пределах клетки, прежде всего в те участки, где эта энергия необходима.

В обычных условиях большая часть энергии идет именно на образование АТФ. Но в случае возникновения стресса, в частности, при понижении температуры, синтезируемые растением белки направляют дыхание так, чтобы больше выделялось именно тепла. В итоге 
растение повышает температуру своего тела на 4-10 градусов по сравнению с температурой окружающей среды.

Белки являются биополимерами, т.е. их молекулы состоят из отдельных повторяющихся частей - мономеров, в качестве которых выступают аминокислоты. Каждый школьник скажет, что в составе белков живых организмов наиболее часто встречаются лишь двадцать аминокислот, в то время как общее их число достигает нескольких сотен.

Активно участвуя в процессах обмена веществ, белки в растениях, кроме того, могут накапливаться, образуя аморфные или кристаллические структуры. Их можно обнаружить в различных органоидах клетки - ядре, цитоплазме, хлоропластах и митохондриях. Наиболее часто белки встречаются в запасающих клетках семян. В процессе образования семени белки откладываются в запас в вакуолях. Впоследствии вакуоли теряют воду, белки кристаллизуются, в результате чего образуются так называемые алейроновые зёрна. Они свойственны семенам масличных растений, представителям злаковых, бобовых.

Бобовые содержат особенно много белков. Это связано с тем, что растения этого семейства (хотя и не только его одного) вступают во взаимовыгодные симбиотические отношения с клубеньковыми бактериями, обладающими способностью фиксировать атмосферный азот, который растения самостоятельно использовать не могут. А азот входит в состав аминокислот, образующих белки. Бактерии переводят азот в формы, доступные для растений, поэтому азотистых соединений накапливается много, не случайно многие бобовые признанные кормовые культуры. Кстати, забавно, что азот, важнейший для земной жизни элемент, получил такое неподходящее название (в переводе с греческого «азот» означает «не поддерживающий жизнь»).

Из наиболее известных бобовых культур, дающих белки, можно назвать сою, горох, фасоль, бобы. Приморцам хорошо знакомо так называемое «соевое мясо», примерно на 50\% состоящее из белков. Его получают из обезжиренной соевой муки, которую варят, а затем прессуют. Важно, что в таком «мясе» мало углеводов. Довольно часто мы используем белки и другого бобового - арахиса, родина которого - Южная Америка. В Приморском крае - на Горнотаежной станции - ещё в тридцатые годы прошлого века пытались выращивать арахис. Первые опыты оказались удачными, но дальше первичного культивирования дело не пошло.

В Приморье произрастают более 90 видов семейства Бобовые из почти 30 родов. Многие из них используются в качестве кормовых (например, виды клевера, люцерна посевная), а целый ряд - культивируется (соя, фасоль, вигна, куммеровия и др.).

Интересно, что растения научились использовать даже разложение белков. Дело в том, что при этом образуются вещества, обладающие весьма неприятным запахом.

При распаде белков, не содержащих серу, ими являются крезол, скатол, индол и некоторые другие дурнопахнущие вещества. При распаде серосодержащих белков выделяются сероводород и меркаптаны, имеющие запах тухлых яиц.

Здесь нужно отметить, что, например, скатол, являющийся производным дициклического соединения индола и придающий специфический запах фекалиям, в малых количествах обладает цветочным ароматом и находит применение в парфюмерии. Да и индол, в чистом виде имеющий запах нафталина, нередко содержится в эфирных маслах и также используется в парфюмерии в качестве фиксатора запаха.

Зачем же растениям понадобилось производить дурнопахнущие вещества? Дело в том, что многие виды используют их для привлечения насекомых, опыляющих цветки. А точнее, мух, которых только такие запахи и могут приманить. В основном это растения тропиков - стапелии из семейства Кутровые, аронник, аморфофаллус из семейства Ароид- 
ные. Их цветки издают запах гниющего мяса, причём самым отвратительным «ароматом» обладает аморфофаллус титанический, который при прикосновении к нему «выстреливает» запахом, чем-то похожим на смесь тухлых яиц и рыбы.

Повстречать плохо пахнущие растения можно и в Приморье. Так, привлекающий опылителей-насекомых неприятный «аромат» издают оригинальные цветки кирказона маньчжурского (семейство Кирказоновые).

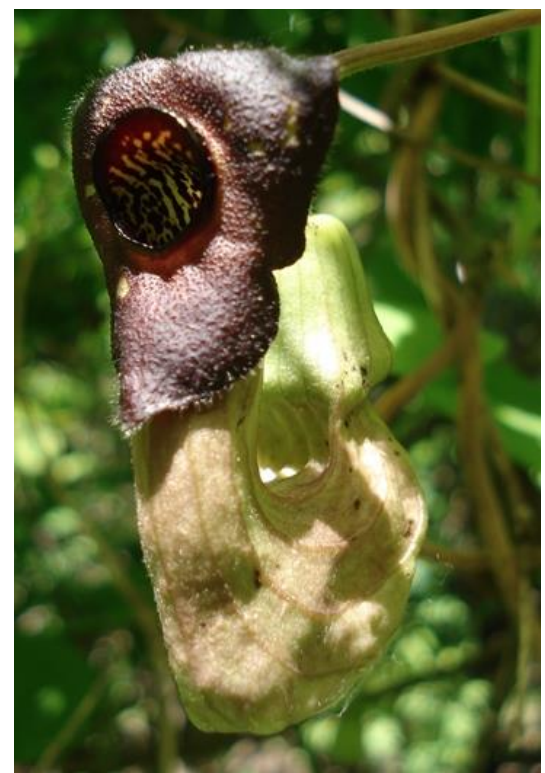

Цветок кирказона маньчжурского

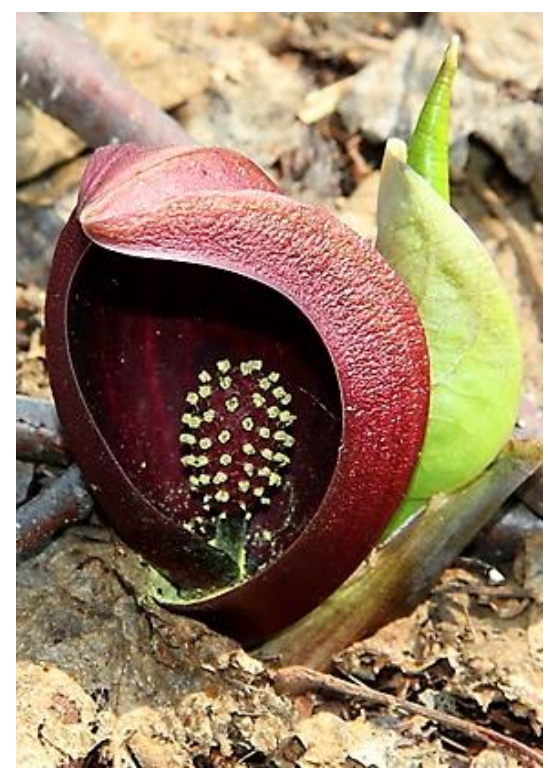

Соцветие связноплодника почколистного (http://florapedia.ru)

Весной, примерно в конце апреля, по сырым местам в долинных лесах появляются весьма причудливые соцветия связноплодника почколистного, принадлежащего семейству Аировые (Ароидные). К этому же семейству принадлежит, например, часто используемая в букетах калла. И у каллы, и у связноплодника один и тот же тип соцветия - початок. У каллы он довольно компактный, цилиндрический, окружен снежно-белым прицветным листом покрывалом. У связноплодника, который цветет еще до появления листьев, початок почти округлый, а покрывало от тёмно-фиолетового до тёмно-пурпурного, размер соцветия с покрывалом доходит до 20-22 см. Если поднести соцветие связноплодника к лицу, можно почувствовать довольно неприятный, чем-то сходный с чесночным, запах. Он-то и привлекает опылителей-мух. За эту особенность растение до недавнего времени носило название симплокарпус вонючий.

\section{Углеводы}

С группой химических веществ, которые долго называли сахарами, человек познакомился еще на заре цивилизации. Изготовление тканей, обработка древесины, получение сладких продуктов - все эти процессы так или иначе связаны с превращением углеводов.

В 1844 году химик Карл Эрнст Шмидт (будущий профессор Дерптского, ныне Тартуского, университета) обратил внимание на то, что состав недавно открытой глюкозы и ряду других сахаров отвечает простейшей комбинации углерода и воды (соотношение водорода и кислорода такое же, как и в воде), а общий состав описывается формулой $\mathrm{C}_{\mathrm{a}}\left(\mathrm{H}_{2} \mathrm{O}\right)_{b}$. Он 
предложил назвать эту группу веществ углеводами - этот термин используется и сегодня, несмотря на то, что существуют и другие вещества сходного соотношения (уксусная кислота, например). Помимо углерода, кислорода и водорода, в редких случаях в молекуле углевода может присутствовать и азот.

Углеводы в растениях выполняют две важнейшие функции - структурную и энергетическую. Одной из отличительных черт клеток растений является наличие углеводной (а именно, целлюлозной) клеточной оболочки, придающей ей форму и служащей надежной механической опорой. А при распаде углеводов в процессе клеточного дыхания выделяется энергия, без которой немыслимо само существование живых организмов. Поэтому и доходит содержание углеводов в растениях до $90 \%$.

По своему строению углеводы обычно делятся на моносахариды и полисахариды. Bсе они в разном количестве и многочисленных сочетаниях имеются у представителей растительного царства.

Наиболее известные моносахариды - глюкоза, фруктоза, галактоза. Глюкозу можно найти в каждой живой клетке растения, поскольку она является первичным субстратом для получения энергии. Это одно из самых распространённых органических веществ на нашей планете. Много ее в спелых фруктах, нектаре. Как, собственно, и фруктозы (так называемого плодового сахара), о чем говорит само название этого вещества. Фруктоза, кстати, еще слаще глюкозы, она - основной сахар нектара и меда.

Полисахариды состоят из определённого числа «связанных одной цепью» моносахаров. Если их немного, два или три, вещества называются соответственно дисахаридами и трисахаридами (общее их название - олигосахариды). Так, если соединить вместе глюкозу и фруктозу, получится сахароза, или тростниковый сахар - это тот самый сахар, что мы используем в пищу. В молоке животных содержится так называемый молочный сахар - лактоза, которой у растений немного. Она является соединением глюкозы и галактозы. В проросших семенах злаков, мёде содержится мальтоза (солодовый сахар), состоящая из двух остатков глюкозы.

Если к глюкозе и галактозе мы добавим фруктозу, получим трисахарид - рафинозу. Она обнаруживается в спарже, фасоли, свёкле, других овощах. Так получилось, что в бобовых растениях рафинозы довольно много (в сое, например, до 1,6\% от сухого веса), но ферментами, содержащимися в человеческом организме, она не расщепляется. Однако у нас есть помощники - микроорганизмы, обитающие в толстом кишечнике. Они разрушают рафинозу до простых веществ - метана, водорода, углекислого газа. Не что иное, как образование этих газов делает нежелательным употреблять продукты из бобовых перед выходом в общество... Сходное «газообразующее» действие свойственно также содержащемуся в бобовых тетрасахариду стахиозе.

Моносахариды и олигосахариды находятся в цитоплазме растительной клетки и активно используются в различных синтетических процессах.

Одно из наиболее привлекательных для человека свойств сахаров - сладость. И хотя существуют сладкие вещества иной химической природы, например белки (так, получаемый из некоторых растений браззеин в 800 раз слаще сахара, а монеллин - в 3000 раз!), углеводы за счет своей более частой встречаемости играют основную пищевую роль.

Важнейшие мировые сахароносы - сахарный тростник, сахарная свекла, сахарная пальма, сахарный клён. Последнее растение используют в США и Канаде для получения пасоки - так же, как мы используем, скажем, берёзу для получения берёзовой пасоки, или берёзового сока. Только сок сахарного клёна гораздо слаще - он содержит до 65\% сахарозы 
(у берёзы - около 2\%). В упомянутых странах существует целая индустрия получения кленового сока. После сбора его концентрируют, получая кленовый сироп, который уже идет на изготовление самых разных сладостей. Недаром лист сахарного клёна изображен на флаге Канады.

Справедливости ради нужно сказать, что и у нас некоторые виды клёна используются для получения сока. Это прежде всего клён мелколистный - достаточно крупное дерево, часто встречаемое в лиственных и смешанных лесах Приморья. Получают сок и из ореха маньчжурского (семейство Ореховые), тоже весьма распространённого в нашем крае. Как у клена, так и у ореха сок более сладкий, чем берёзовый (содержит до $3 \%$ сахара), но его растения выделяют меньше и с неясной периодичностью. Да и известен орех в Приморье скорее как обладатель красивой древесины, используемой для разных поделок, а также известное лекарственное растение, причём в ход идут почти все его части - кора, древесина, листья и плоды. Кроме того, из околоплодника варили варенье со своеобразным вкусом, из него можно получить тёмно-коричневую краску, а в ядрах орехов содержится до 50\% жира.

Основным же дарителем весеннего освежающего напитка является, конечно, бёреза из одноименного семейства. Для подсочки в основном используются берёзы даурская и плосколистная. Белоствольную берёзу плосколистную в лесу узнает каждый, да и даурскую заметить довольно легко - ее кора отслаивается многочисленными тонкими пластинками, как бы налегающими одна на другую.

Очевидные поставщики сладкой продукции - плодово-ягодные растения, на основе которых, часто с использованием меда, на Руси делали сладости. Много сахаров (до 40\%) в корневищах камыша озёрного, из которых можно получать сладкий сироп.

Полисахариды играют важную роль в жизни растений.

Постоянное изменение условий существования требует наличия запаса веществэнергоносителей. На первом месте среди запасных веществ растений и стоят углеводы. Образующаяся в процессе фотосинтеза глюкоза впоследствии превращается (полимеризуется) в крахмал, который откладывается в различных органах, чаще подземных - клубнях, корневых шишках, корневищах. По мере необходимости он вновь деполимеризуется до глюкозы, которая, расщепляясь до углекислого газа и воды в процессе клеточного дыхания, даёт вожделённую энергию.

У некоторых растений крахмала накапливается очень много, и их начал использовать в пищевых целях человек. В разных регионах планеты появились свои крахмалоносные культуры. Кроме известных пшеницы, ячменя, ржи и других злаков это маниок из семейства Молочаевые (родина - Бразилия), батат из семейства Вьюнковые (тропическая Америка), ямс из семейства Диоскореевые (Азия, Африка, Южная Америка) и целый ряд других.

Некоторые признанные крахмалоносные культуры широко выращиваются и в Приморье - картофель из семейства Паслёновые («Небось, картошку все мы уважаем!..», пел Владимир Высоцкий), такие злаки, как рис, кукуруза.

В то же время есть у нас аборигенные растения, в которых также много крахмала. Это в большинстве своём корневищные многолетники из семейств Мятликовые (Злаковые), Рогозовые, Сытевые (Осоковые), реже других семейств.

У большинства дикорастущих приморских крахмалоносов в пищевых целях используются корневища. Это прежде всего виды рогоза из одноимённого семейства. Всего их в Приморье шесть, но более известен рогоз широколистный, который узнается по тёмнокоричневым «бархатным» цилиндрическим женским соцветиям. Его корневища содержат до 46\% крахмала, а кроме того белки и углеводы. Их можно употреблять в сыром, варёном, пе- 
чёном виде, а можно изготовить муку и использовать её в качестве добавки к пшеничной или ржаной. Таким же образом можно использовать корневища тростника южного из семейства Мятликовые - они содержат до 50\% крахмала. Много крахмала у представителей семейства Сытевые - некоторых камышей, видов рода клубнекамыш. Корневища последних имеют клубневидные утолщения, в которых накапливается до 70\% крахмала. Много крахмала, до $50 \%$, имеется в клубнях стрелолистов из семейства Частуховые. Еще больше, до 60\%, его содержится в корневищах сусака зонтичного из одноименного семейства, который часто называют «якутским хлебом». Запасы крахмала имеются и в корневищах кувшинки четырёхгранной (семейство Кувшинковые).

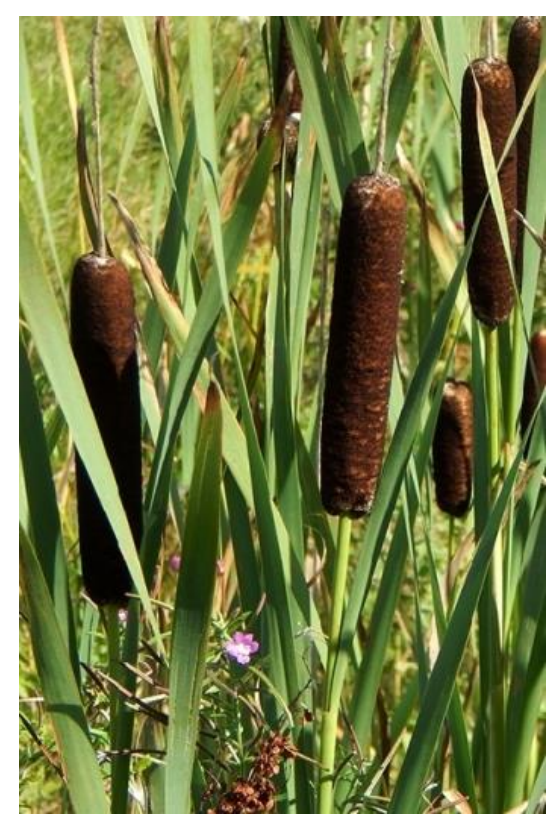

Рогоз широколистный (https://tursar.ru)

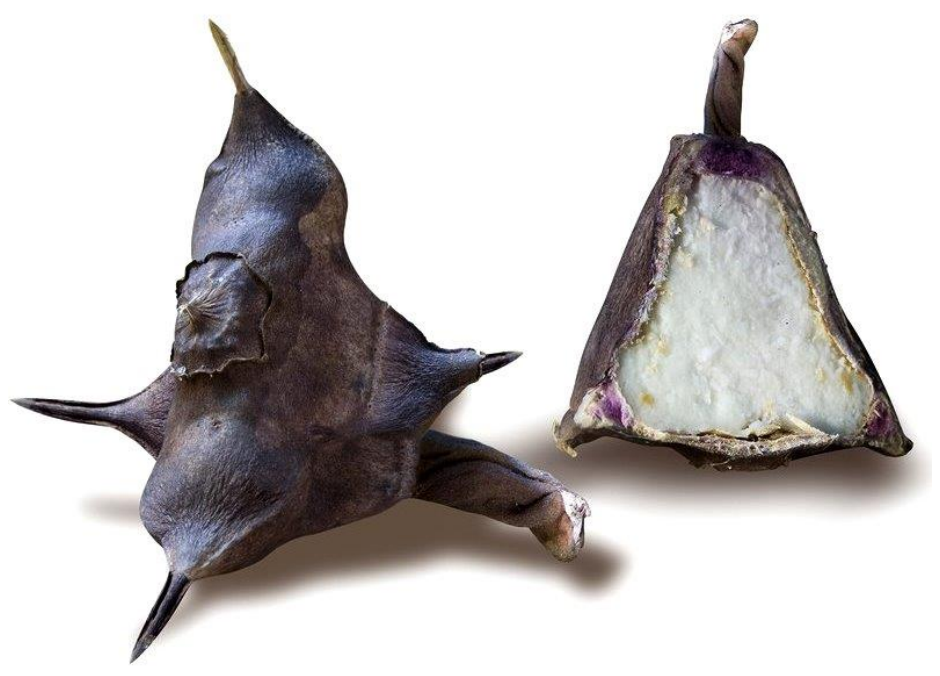

Плоды рогульника (http://florapedia.ru )

В другом плавающем растении - рогульнике из одноимённого семейства, несколько видов которого встречаются в Приморье - крахмал (до 50\% и выше) содержится в плодах. Они тёмно-бурые, снабжены двумя-четырьмя «рогами», играющими защитную и якорную функции. Другие виды рогульника находят широкое пищевое применение в Азии, Африке, однако приморские виды мало используются как пищевые.

Всё это водные или околоводные растения. У сухопутных видов крахмал содержится в корневищах пырея ползучего (семейство Астровые), корневых клубнях тладианты сомнительной (семейство Тыквовые), хвощей. Богаты этим полисахаридом и клубневидные корни пуерарии лопастной из семейства Бобовые, растущей на самом юге Приморского края. В Японии это растение (здесь оно называется «кудзу») является популярным источником крахмала. Наконец, немало этого важного вещества в корневищах бубенчиков (семейство Колокольчиковые), особенно перескиелистного, мутовчатого и трёхконечного, а также иванчая (семейство Кипрейные).

Крахмал можно обнаружить не только в запасающих органах, но и в семенах многих растений - это злаки (ежовник, щетинник, цицания широколистная), представители семейств Маревые (ширица), Гречиховые (гречиха татарская), Буковые (виды дуба). Все эти дикоросы можно использовать в качестве замены традиционным пищевым культурам. Плоды дуба (которые, кстати, нужно собирать ранней весной, когда в них мало ядовитого кверцетина, либо 
обрабатывать вымачиванием и нагреванием) содержат до 40\% крахмала и других полезных веществ. Они издавна использовались для получения муки, но более известны как источник приготовления суррогата кофе.

Приведенные примеры - лишь небольшая часть из обширного числа природных крахмалоносов.

Крахмал является основным запасным веществом у подавляющего большинства растений. Однако многие представители семейства Астровые (Сложноцветные), а также некоторые виды других семейств, отправляют в свои «кладовые» другой углевод - инулин, являющийся полимером фруктозы. В Приморье немало энтузиастов выращивания одного из видов подсолнечника - подсолнечника клубневого, более известного под названиями топинамбур, земляная груша. Родина этого вида - Южная Америка. В начале 17 века он появился в Европе, а спустя столетие - в России. Его сладковатые на вкус клубни можно не только варить и жарить, как и картофель. Инулин считается природным аналогом инсулина, поэтому топинамбур рекомендуют больным сахарным диабетом, да и при других недугах помогает этот выходец из Америки, так как содержит много различных целебных веществ.

Из представителей астровых в Приморье довольно много инулина содержится в корнях лопуха (репейника). Так, его содержание у лопуха большого, довольно распространённого в крае многолетника, доходит до $45 \%$.

Еще один полисахарид, являющийся, как и крахмал, полимером глюкозы и щедро представленный в растениях, - целлюлоза, или клетчатка. По примерным оценкам, на Земле ежегодно образуется около ста миллиардов тонн целлюлозы! Это самое распространённое органическое вещество на планете.

Как уже говорилось, она входит в состав оболочек растительных клеток. Чем больше целлюлозы в оболочке, тем она крепче, тем прочнее ткань, сформированная такими клетками. Например, древесина более чем на 50\% состоит из целлюлозы, волокна хлопчатника содержат ее свыше 90\%, а льна - даже до 98\%! Неудивительно, что эти растения являются традиционными источниками сырья для изготовления тканей. Из льна, например, получают ткани различной степени жёсткости - от грубого брезента до тонкого батиста. Стоит отметить, что волокна этих растений разного происхождения - у хлопчатника они являются придатками семени, а волокна льна находятся в стебле, точнее - в лубе.

На Руси крестьяне, не имея возможности покупать льняную одежду, делали ее из... конопли. Причём в основном использовали не женские экземпляры (конопля - двудомное растение), которые звались материнкой, или матёркой, а мужские, в которых волокно было крепче. Мужские растения конопли назывались посконью, а сама одежда, из нее изготавливаемая, достаточно грубая - посконной. Волокно конопли не только крепкое, но и стойкое к гниению, поэтому из него также делали канаты, рыболовные снасти, парусину.

К углеводам относят также пектиновые вещества - сложные эфиры полигалактуроновой кислоты и метилового спирта. В растворимой и нерастворимой формах они присутствуют в различных частях растений. Важнейшая их роль состоит в том, что они входят в состав срединной пластинки, накрепко соединяющей клеточные оболочки двух соседних клеток. Если под действием ферментов пектиновые вещества разрушаются, что наблюдается, например, при созревании плодов, клетки начинают отходить друг от друга. Этот процесс называется мацерацией; в результате мякоть плода становится рассыпчатой, рыхлой. Кроме того, пектиновые вещества способствуют поддержанию тургора (упругого состояния) тканей, повышают засухоустойчивость растений. 
Их много в плодах черной смородины (семейство Крыжовниковые), яблони, боярышника, сливы (семейство Розовые), клюквы (семейство Вересковые).

Основное свойство пектиновых веществ - способность желировать при взаимодействии с сахарами и органическими кислотами. Это широко используется в кондитерской промышленности при приготовлении желе, джема и других вкусных сладостей. Употребление растительных продуктов, богатых пектинами, весьма полезно для организма - они способны снижать содержание сахара в крови, угнетают гнилостную микрофлору кишечника. Образуя со многими металлами нерастворимые соединения, не усваиваемые кишечником и выводимые из организма, они оказывают радиозащитное действие. При поранениях весьма эффективно использование бинтов, пропитанных двухпроцентным раствором пектиновых веществ: прекращается гноение, рана очищается и быстро заживает.

Еще одной разновидностью полисахаридов являются слизи. Фармакологи и ботаники под слизями понимают вещества углеводного происхождения, которые сильно набухают в воде, образуя вязкую жидкость. Найти слизи можно в коре, корнях, семенах растений. Слизи играют важную биологическую роль: они являются запасными питательными веществами и идут в ход при весеннем прорастании почек; выполняют защитную функцию, предохраняя растение от пересыхания либо, у водных растений, предотвращая вымывание солей. Наконец, слизи способствуют прорастанию семян и их распространению.

Слизи делят на нейтральные (являются результатом полимеризации моносахаридов) и кислые, включающие в себя уроновые кислоты (продукты окисления моносахаридов). Первые встречаются в представителях семейств Орхидные, Лилиевые, Бобовые, вторые - в семенах подорожника, льна из одноименных семейств.

Богатых слизью лекарственных растений не так уж много; к ним относится, например, алтей (семейство Мальвовые). Пригодное для терапевтического использования содержание слизи отмечается у мальвы, льна и исландского мха. В семенах подорожника (семейство Подорожниковые) содержание слизи достигает $44 \%$.

Основное фармакологическое действие растительной слизей - мягчительное. Они оказывают легкое слабительное действие, снимают внутренние раздражения. Еще одно их свойство - ослабление вкусовой чувствительности, особенно к кислому. Например, малина содержит меньше сахара и больше кислоты, чем чёрная смородина, но из-за того, что она богаче слизистыми веществами, она слаще на вкус, чем смородина.

О роли углеводов в жизнедеятельности растений и их практическом значении можно говорить еще долго. Мы остановились лишь на некоторых из них, но и этот краткий обзор свидетельствует о важности углеводов для растений и человека.

\section{Липиды}

К липидам относят жиры и жироподобные вещества разнообразной химической природы, общим свойством которых является нерастворимость в воде и вообще её боязнь (или, как говорят учёные, гидрофобность).

В растениях содержатся разнообразные жиры, представляющие собой соединение трёхатомного спирта глицерина и высокомолекулярных жирных кислот, среди которых наиболее часто встречаются пальмитиновая, олеиновая, линолевая и некоторые другие. Часто жиры растений называются растительными маслами.

Функции жиров в растительном организме достаточно разнообразны. Прежде всего, такие представители жиров, как фосфолипиды являются структурной основой клеточных 
мембран, которые не только отграничивают клетку от внешней среды, но и составляют внутриклеточные органоиды - аппарат Гольджи, эндоплазматическая сеть и др. Запасные жиры представляют собой источник энергии, который используется клеткой при нехватке углеводов. При этом распад жиров сопровождается даже большим выделением энергии, чем распад углеводов. Кроме того, при окислении жиров образуются промежуточные продукты, используемые для синтеза широкого круга других соединений.

Нередко жиры накапливаются в растениях, которые благодаря этой особенности получили название масличных. Обычно они концентрируются в плодах и семенах, причём их количество может достигать больших величин. Так, в плодах маслины из одноименного семейства содержится 50\% масла, семенах клещевины (семейство Молочаевые) - 60\%, конопли (семейство Коноплевые) - 30\%, сои (семейство Бобовые) - 20\%. Растительные жирные масла богаты непредельными (содержащими двойные химические связи) жирными кислотами, поэтому при комнатной температуре они в своем большинстве жидкие. Исключения немногочисленны - например, масло какао (или шоколодного дерева, семейство Мальвовые), основной компонент которого - тристеарин. При комнатной температуре оно твёрдое, а при температуре $32-36^{\circ} \mathrm{C}$ - жидкое. Именно поэтому шоколад, который его содержит, так быстро «тает» в руках. Это свойство делает масло какао пригодным для изготовления суппозиториев (медицинских свечей). Твёрдое растительное масло получают также из манго (семейство Анакардиевые), карите (или ши, семейство Сапотовые).

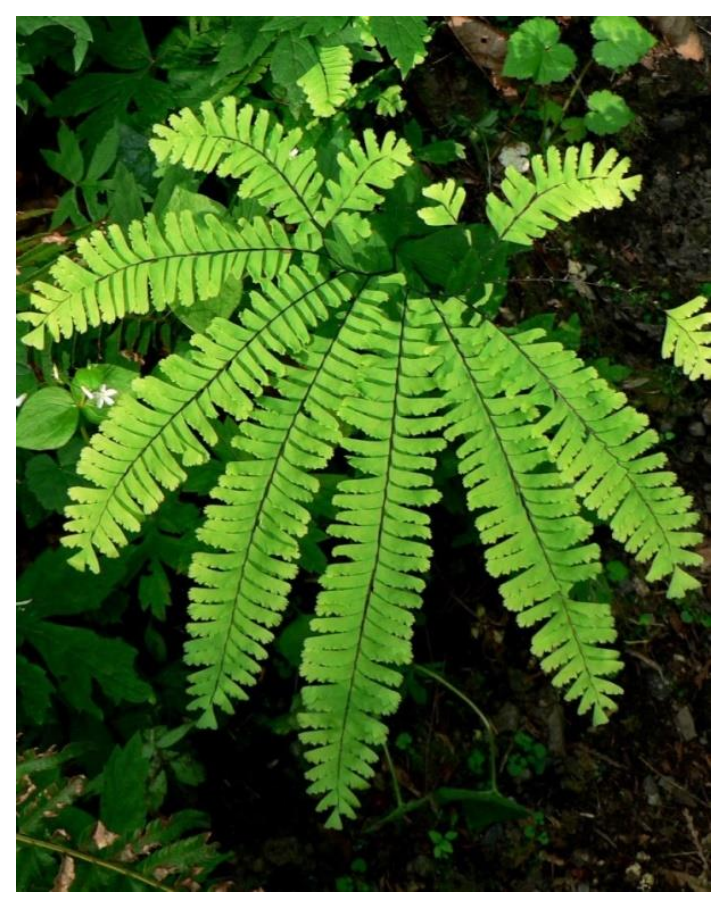

Адиантум стоповидный (https://upload.wikimedia.org)

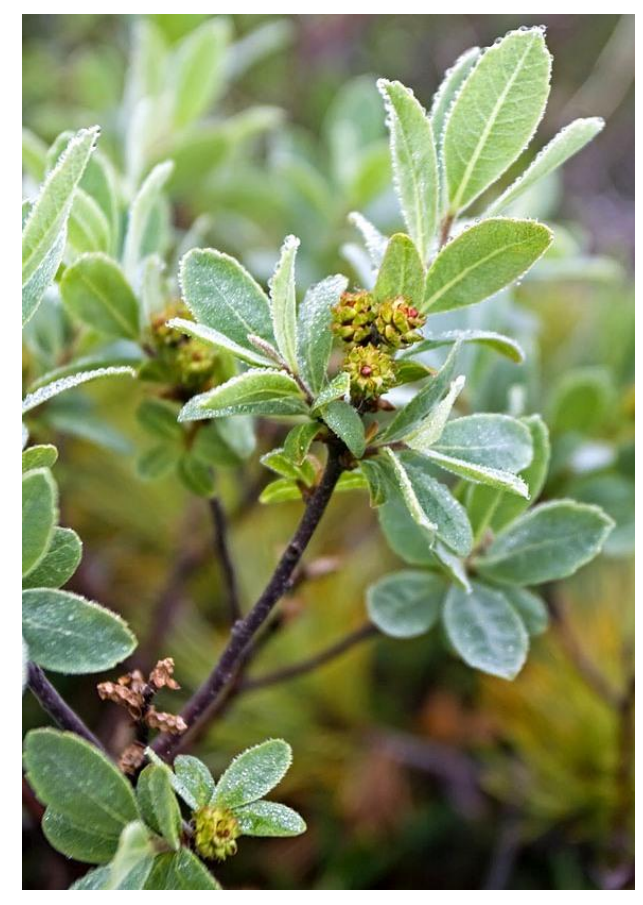

Восковник пушистый (https://www.plantarium.ru)

Признанных масличных растений в Приморье нет, но жирные масла содержат довольно много видов - в разных, правда, количествах. Имеется масло в основном в семенах ореха маньчжурского из одноимённого семейства (более 60\%), сосны корейской из семейства Сосновые (до 60\%), иван-чая из семейства Кипрейные (до 45\%), осота полевого (семейство Астровые), ильма японского из одноимённого семейства и пастушьей сумки из капустовых(до 30\%), лопуха из семейства Астровые (до 20\%) и др. Масло некоторых растений нахо- 
дило пищевое и техническое применение. В семенах ясеня маньчжурского (семейство Маслиновые) до 20\% масла, оно тёмно-зелёное, с приятным запахом, используется в лакокрасочной, мыловаренной промышленности.

Среди жироподобных веществ необходимо упомянуть растительные воски. В химическом отношении воски, так же как и жиры, являются сложными эфирами жирных кислот и спиртов, но не глицерина, а высокомолекулярных одноатомных спиртов алифатического ряда. В отличие от жирных масел они имеют твёрдую консистенцию. В растениях воски обычно находятся в виде тонкого слоя кристаллов различной формы либо в аморфном виде. Покрывая листья, плоды и другие части растений, они выполняют главным образом защитную функцию - предотвращают излишнее испарение воды (белый налет воска отражает солнечные лучи и уменьшает нагрев органа), проникновение микроорганизмов.

У некоторых растений восковой слой препятствует смачиванию водой - она быстро скатывается с листьев. Это свойственно, например, папоротникам рода адиантум из одноименного семейства. В лесах Приморья произрастает один из видов рода - адиантум стоповидный. Это весьма изящный папоротник, растущий в смешанных и лиственных лесах. Черно-бурые блестящие черешки, на верхушке вильчато разветвляясь, несут небольшие многочисленные продолговатые, очень тонкие перышки. Нельзя не остановиться и не полюбоваться таким чудом природы! Правда, его нежные перышки повреждаются при малейшем понижении температуры...

Широко известны голубые формы ели (семейство Сосновые) - на её листьях (хвое) откладывается значительное количество воска, что придает им, и в целом кроне, голубоватый оттенок.

Некоторые растения образуют очень много воска, который использует человек. Это в основном пальмы - например, цероксилон горный, растущий в Южной Америке, или коперниция восковая (карнауба), произрастающая в Бразилии. Ствол цероксилона (это, кстати, самая высокая пальма, достигающая 60 м высоты) покрыт толстым слоем воска, с одной особи можно собрать 10-20 кг. А у карнаубы воск слоем 5-7 мм покрывает молодые листья.

В Приморье произрастает один из представителей довольно крупного рода восковник из одноимённого семейства. Некоторые виды этого рода, например, североамериканские восковники восконосный и каролинский, дают воск, который использовали для изготовления свечей. Причём у первого вида воск накапливается на плодах, а у второго - на листьях. А вот у нашего растения, восковника пушистого, у которого воск откладывается на плодах, его не столь много. Этот небольшой, до полутора метров высоты, двудомный кустарник растёт по болотам и лугам, берегам водоёмов.

Воскоподобным веществом, выделяемым клетками эпидермы, является кутин. Он образует на поверхности листьев так называемую кутикулу - тонкий слой кутина, часто вместе с восками. Кутикула играет защитную роль, её толщина различна у разных растений.

Еще одно замечательное жироподобное вещество - суберин. Он откладывается в оболочках растительных клеток, вызывая их опробковение. Из-за того, что суберин отличается химической инертностью, оболочка становится прекрасным изолятором. Если опробковевает вся оболочка, внутреннее содержимое клеток отмирает.

Совокупность таких мертвых пустых клеток образует особую ткань - пробку. Она не пропускает через себя ни свет, ни газы, ни электричество, ни воду. Пробка образуется, например, при поранениях ствола и ветвей и защищает растение от проникновения инфекции. А осенью, перед листопадом, отделительный пробковый слой образуется в основании 
черешков листьев. Он не только облегчает последующее опадение листьев, но и изолирует место отделения листа от стебля.

Основное же место формирования пробки - стебли древесных растений. У молодого однолетнего побега стебель покрыт эпидермой, защищающей нежные внутренние ткани от неблагоприятных внешних условий и представляющей собой обычно один слой живых клеток. В состав эпидермы листьев входят устьица, играющую важную роль в регулировании дыхания и транспирации (испарения воды) растений.

По мере роста растения эпидерма заменяется другой, вторичной покровной тканью перидермой. Она состоит уже из нескольких слоев клеток, выполняющих различные функции. Снаружи находится пробка (число слоев клеток, составляющих ее, различно у разных видов), затем идет один слой клеток образовательной ткани - пробкового камбия, далее располагаются клетки феллодермы, обеспечивающие питательными веществами пробковый камбий, который является, в свою очередь, главным «поставщиком» пробки. Как видно, это уже более мощная «оборона» растения, имеющая важное значение для противостояния низким температурам зимы. У древесных растений эпидерма сменяется перидермой примерно в середине лета, при этом зелёный цвет побегов переходит в серый (ильм из одноимённого семейства) или коричневый (черёмуха обыкновенная, семейство Розовые).

У некоторых деревьев (черёмуха обыкновенная, трескун амурский из маслиновых и др.) перидерма откладывается только один раз, у большинства же видов происходит ежегодное ее отложение. В результате формируется корка или, как мы привыкли говорить, кора деревьев. Вследствие того, что новая перидерма закладывается в более глубоких слоях ствола, новые участки давят на старые слои (ствол ведь растёт не только в длину, но и в ширину). Кора растрескивается и образует рисунок, индивидуальный у разных видов растений.

Есть растения, у которых образуется достаточно мощный слой пробки. Это свойственно, например, кирказону маньчжурскому из одноименного семейства. Толщина пробки у него достигает одного сантиметра.

Еще более толстый пробковый слой формируется у хорошо знакомого всем жителям Дальнего Востока бархата амурского (семейство Рутовые), который часто и называют пробковым деревом. Мощность пробки у бархата достигает 2,5-3 сантиметров. Это несколько меньше, чем, например, у пробкового дуба, произрастающего в Средиземноморье. У него слой пробки имеет толщину до 5 сантиметров.

Бархат амурский - удивительное растение, поэтому о нём стоит рассказать несколько подробнее.

Встретить его можно и в северном Китае, и на Корейском полуострове, и на нашем Дальнем Востоке, где он произрастает в смешанных и хвойно-широколиственных долинных лесах, не поднимаясь выше пятисот метров над уровнем моря. Бархат отнюдь не гигант, но на юге ареала его высота достигает двадцати и даже двадцати восьми метров.

Пробковое дерево легко узнать по характерной бороздчатой светло-серой мягкой коре, сложным пахучим листьям, чёрным ягодообразным плодам. На листьях находятся миниатюрные желёзки, которые при повреждении (растирании листа, например) выделяют секрет, своеобразный запах которого запоминается уже с первого раза. Плоды собраны в метельчатые соплодия, благодаря которым в Китае бархат получил название «дерево чёрного жемчуга» - они напоминали китайцам связки жемчуга.

Амурский бархат с полным основанием можно назвать чудо-деревом. Не в отношении каких-то внешних его особенностей, а в плане использования человеком. 


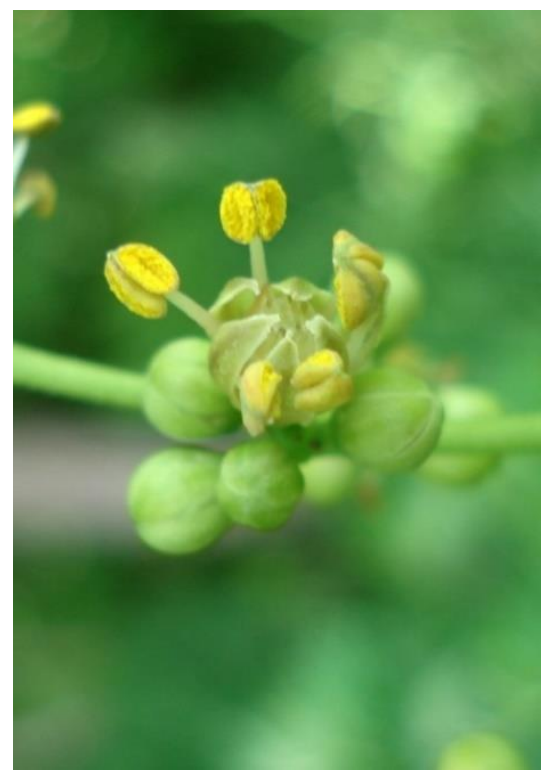

Цветок бархата амурского

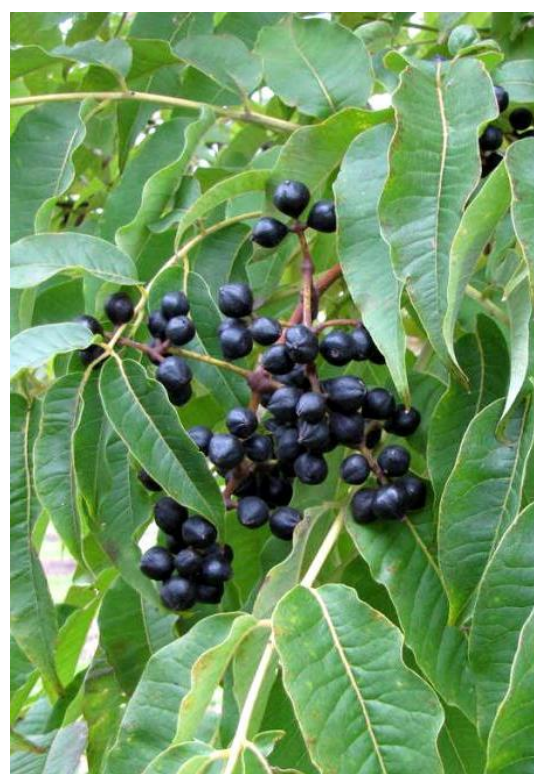

Плоды бархата амурского (https://klumba.guru)

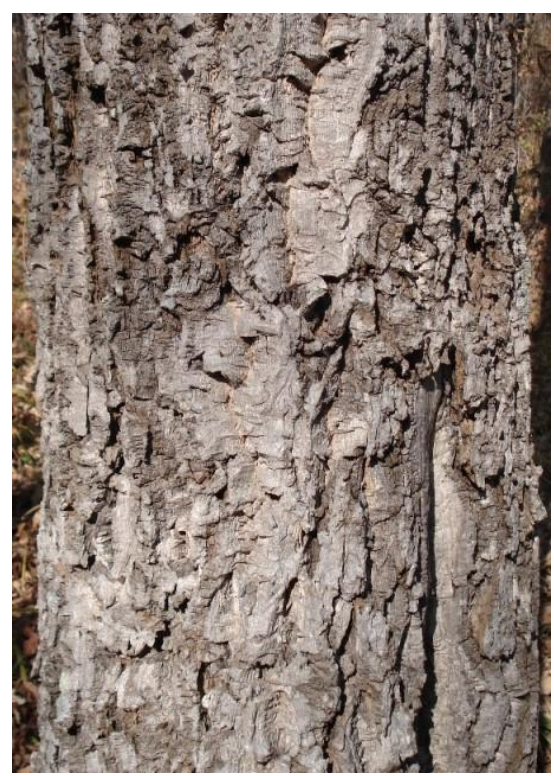

Кора ствола бархата амурского

Прежде всего, бархат - замечательное техническое растение. Важнейшее его значение заключается в том, что он является поставщиком пробки. Как уже говорилось, пробка - прекрасный изоляционный материал. Она не пропускает сквозь себя ни жидкость, ни газ, не проводит тепло, электричество и звук, упруга и эластична. Подобное сочетание свойств пробки настолько уникально, что никакие пластмассы пока не могут равноценно заменить её. И спектр использования пробки весьма широк - не говоря уже о виноделии, она идет на изготовление изоляционных плит, поплавков, протезов, дисков для полировки оптики, применяется в судостроении, авиационной промышленности - всего и не перечислишь.

Добыча пробки - весьма прибыльное дело, поскольку, согласно прогнозам, её вскоре потребуется очень много - в частности, в связи с тем, что сейчас получает распространение практика облицовки стен зданий пробковыми плитами (кстати, здания с подобной облицовкой, построенные в Москве и Петербурге на рубеже 19-20 веков, успешно эксплуатируются и сегодня). И хотя львиная доля мирового использования пробки приходится на пробковый дуб (ежегодная добыча которого составляет 360 тысяч тонн), перспективы вовлечения бархата в «пробковую индустрию» весьма впечатляющи.

На Дальнем Востоке сбор пробки впервые стали осуществлять в начале тридцатых годов прошлого века, для чего были созданы целые плантации. В определённый срок с дерева деревянной лопаточкой снимают пробку (причём со всего ствола), оставляя дерево «голым». Однако оно не погибает, а тут же начинает формировать новый слой пробки. Да так быстро, что лет через девять-десять уже можно производить вторичный съём, причём новая пробка более качественна. В некоторых случаях проводили и третье «раздевание» дерева. Когда-то на Дальнем Востоке добывали до нескольких тысяч тонн пробки бархата. Однако эта индустрия не получила дальнейшего развития.

Кроме пробки, у бархата в ход идет и древесина. Она имеет красивый рисунок, легко полируется, в сухом состоянии довольно легкая. А содержание противогнилостных веществ предохраняет ее от повреждений насекомыми. Из древесины бархата делали мебель, лыжи, детали самолётов и автомобилей. 
А из луба, который у бархата имеет ярко-жёлтый цвет, раньше изготавливали лимонно-жёлтую краску для окрашивания тонких тканей и сафьяна. Из плодов можно получать зелёную краску.

Плоды бархата несъедобны, однако он является хорошим пыльценосом и медоносом. В отдельные годы одна пчелиная семья может добыть 25-30 кг меда. Бархатовый мёд тёмножёлтый, со своеобразным запахом, долго не кристаллизуется. Он ценится как ценное противотуберкулёзное средство.

Разработан сок «Амурский бархат», обладающий общеукрепляющим эффектом. Основой его служит яблочный сок. Добавление к соку плодов бархата придаёт продукту пряный запах, и вдобавок сок приобретает лечебные свойства - он стимулирует работу почек и поджелудочной железы.

Бархат - известное лекарственное растение. Он находит применение почти во всех восточных медицинах. В качестве лекарственной части выступают луб, листья, плоды, кора.

Особенно широкое применение находит луб. В нем содержится до двух процентов алкалоидов, главным из которых является берберин. В старину говорили, что если растение имеет жёлтые части, его можно использовать для лечения заболеваний печени. В отношении бархата с его ярко-жёлтым лубом это вполне справедливо. Из луба бархата получают берберин, который используют как желчегонное средство при холециститах с поражением желчных путей.

Ещё одно применение луба - в качестве заживляющего средства при поранениях и ожогах. Если прокипятить луб в воде, получится киселеобразная масса, которой обрабатывают поражения, при этом заживление значительно ускоряется.

Наконец, луб бархата часто применяют при заболеваниях органов дыхания - туберкулёзе, пневмонии, гриппе. Так, при туберкулёзе лёгких препараты бархата снижают температуру, улучшают аппетит, ослабляют кашель.

В Китае луб бархата включён в Фармакопею и назначается при нефрите, проказе, инфекционной желтухе, нейродермите, полиартрите и ещё добром десятке заболеваний.

Не остались в стороне и листья - из них получают препарат флакозид, используемый для лечения гепатитов А и Б, а также при лечении гепатитов невирусной этиологии (токсического, например, или алкогольного).

Плоды также обладают определённой лечебной силой. Так, в корейской народной медицине ежедневное употребление двух-трёх плодов считалось полезным при сахарном диабете. А из местных народных рецептов можно упомянуть использование плодов при ангине. Нужно взять сухой плод бархата и разжевать его, не проглатывая. На вкус он довольно противный, горький, но что не сделаешь ради выздоровления...

В последнее время разрабатываются лекарственные средства, в состав которых входит бархат амурский. Пример - препарат «Диэнай» на основе экстракта бархата, обладающий противовирусным, гепатопротекторным, антиаритмическим действием. Экстракт бархата входит и в препарат «Гепалам», назначаемый для лечения заболеваний печени и жёлчного пузыря, а также при геморрое, гастрите, язвенной болезни. Разработана биологически активная добавка к пище «Потенцироз», в которую входят плоды бархата и которая предназначена для повышения сексуальной активности у мужчин. 


\section{Органические кислоты}

Органические кислоты - одни из самых задействованных соединений в растительном организме. Эти вещества характеризуются наличием одной или нескольких карбоксильных групп (-СООН), что придает им кислотные свойства. Они могут также содержать циклические группировки (ароматические кислоты) либо не иметь их (жирные, или алифатические кислоты, которые названы так потому, что входят в состав животных жиров и растительных масел). В растениях они содержатся как в свободном виде - главным образом в плодах, так и в виде солей или эфиров - прежде всего в листьях. Много органических кислот в плодах клюквы болотной (семейство Вересковые), земляники восточной (семейство Розовые).

Кислоты алифатического ряда обычно разделяют на летучие и нелетучие.

Нелетучие органические кислоты - пировиноградная, щавелевоуксусная, молочная и др. - являются важнейшим связующим звеном в обмене жиров, углеводов и белков. Они образуются как промежуточные продукты в реакциях фотосинтеза и дыхания и впоследствии используются для образования самых разных органических соединений - аминокислот, гликозидов, алкалоидов.

Многие органические кислоты отвечают за вкус растений, например, яблочная или лимонная. Яблочная кислота обнаруживается прежде всего в плодах яблони, сливы, рябины (семейство Розовые), но есть она в надземных частях чистотела (семейство Маковые), плодах можжевельника (семейство Кипарисовые). Лимонной кислоты очень много в цитрусовых, особенно в лимонах (из них она и была выделена Карлом Шееле в 1784 году), но она есть также в плодах брусники, клюквы, лимонника китайского. Плоды винограда богаты винной кислотой.

Очень широко представлена в растениях щавелевая кислота. Больше её в листьях в листьях щавеля, кислицы, меньше - сотые доли процента - в плодах многих растений. У некоторых видов она содержится в виде соли - щавелевокислого кальция. Его образуется так много, что он кристаллизуется. Кристаллы могут быть одиночными, чаще призматическими - их можно обнаружить в клетках чешуи лука (семейство Луковые), стеблей бузины (семейство Жимолостевые), крапивы двудомной (семейство Крапивовые). В стеблях винограда (семейство Виноградовые) и рогоза узколистного (семейство Рогозовые), корневищах купены (семейство Ландышевые) встречаются игольчатые кристаллы - рафиды. Сросшиеся кристаллы (друзы) находят в клетках крапивы двудомной из одноимённого семейства.

К летучим кислотам относят муравьиную, уксусную, пропионовую, масляную, валериановую, изовалериановую и другие кислоты. Эфиры летучих органических кислот отвечают, в числе других веществ, за запах растений.

Самая простая из летучих кислот - муравьиная кислота. Впервые она была получена английским натуралистом Джоном Реем в 1671 году - с этой целью он из множества мёртвых рыжих муравьёв приготовил эссенцию, в которой и обнаружил кислоту. Муравьиная кислота содержится в тысячелистнике (семейство Астровые), малине (семейство Розовые), крапиве, хвое голосеменных и других растениях. Она зарегистрирована в качестве пищевой добавки под номером Е236. Валериановая кислота есть в корнях валерианы (семейство Валериановые), плодах калины (семейство Жимолостевые) и др.

Ароматические кислоты (салициловая, кумаровая, кофейная, хинная и др.) обладают лекарственными свойствами. 
Бензойной кислотой богаты плоды клюквы и брусники (семейство Вересковые), где она содержится как в свободном виде, так и в виде гликозида вакциниина. Эта кислота способствует продолжительному хранению плодов, являясь естественным консервантом.

Гликозиды и эфиры салициловой кислоты найдены в плодах малины, ежевики (семейство Розовые), коре различных видов ив (семейство Ивовые). От латинского названия рода ива - Salix («саликс») - и произошло название этого химического соединения. Известное производное салициловой кислоты, аспирин, мы традиционно используем в качестве жаропонижающего средства, если нечаянно подхватываем простуду.

Хлорогеновая, кофейная, хинная, шикимовая и другие фенолокислоты обладают желчегонным, мочегонным и в некоторой степени капилляроукрепляющим и противовоспалительным действием, регулируют функцию щитовидной железы.

Уроновые кислоты (глюкуроновая, галактуроновая, маннуроновая и др.) участвуют в образовании таких высокомолекулярных соединений, как пектиновые вещества, слизи, камеди.

\section{Витамины}

Эпоха Великих географических открытий (14-17 века) подарила европейцам не только доселе неведомые страны, но и различные экзотические продукты, прежде всего пряности, которыми были особенно богаты страны Востока. Однако на пути к ним приходилось преодолевать многие тысячи километров водной глади, и столько же, а нередко и больше, требовалось на обратную дорогу.

Основным бичом длительных морских путешествий, как свидетельствует история мореплавания, стали не пираты, кораблекрушения или жестокие туземцы, а неведомое тогда заболевание - цинга. Из-за неё суда иногда лишались до трети своих команд (в одной из экспедиций Васко да Гамы в поисках Индии умерли 100 человек из 160). У людей начинали кровоточить и распухать дёсны, расшатываться зубы, а тело покрываться гнойниками. Невозможно было жевать и глотать, из-за чего многие погибали. Но если вдруг удавалось найти свежую еду, в частности фрукты, то болезнь проходила. Все указывало на то, что причиной цинги являлась пища (а в качестве неё чаще всего выступали солонина, галеты, реже солёная рыба), в которой не хватало каких-то веществ.

Причину цинги не могли обнаружить довольно долго. Однако предотвратить её сумели раньше - как оказалось, если в рацион включить лимоны, то болезнь не возникает. Уже в 18 веке бочонки с лимонами стали обязательным компонентом судовой провизии.

Но не все было так гладко. Пытаясь объяснить, почему лимоны предотвращают цингу, медицинские светила того времени пришли к выводу: поскольку море - стихия солёности и горькости, сахар - стихия сладости, именно недостаток четвёртого вкуса, солёности, является причиной расстройства организма. Однако лимоны всё же дорогие, почему бы не воспользоваться другим поставщиком кислости - уксусом? Но, увы, уксус не приводил к такому же оздоравливающему эффекту, как лимоны.

Значит, в лимонах, да и вообще в еде, что-то есть... Требовался учёный, который подтвердил бы это в эксперименте. Им оказался русский врач Николай Иванович Лунин. В качестве «подопытных» он избрал мышей. Одним он давал коровье молоко, а другим - те вещества, которые входили в состав молока (белки, жиры, сахар, минеральные соли). И что же? Мыши, употреблявшие коровье молоко, чувствовали себя прекрасно, а те животные, которым скармливали раствор отдельных веществ, хирели и в конце концов погибали. 
Вывод был однозначным: в молоке и, вероятно, в другой пище присутствуют какие-то вещества, причём в очень малых количествах, без которых нормальная жизнедеятельность организма невозможна. Этот вывод Н.И. Лунин сделал в своей докторской диссертации «О значении неорганических солей для питания животных» (1880 год).

Его опыты не замедлили повторить другие учёные и... ничего подобного лунинским результатам не получили. Как выяснилось впоследствии, Лунин в своих экспериментах использовал тростниковый сахар, а его последователи - плохо очищенный молочный сахар, в котором это пока загадочное вещество все же присутствовало.

Вскоре такие вещества были обнаружены при изучении другой болезни - бери-бери (полиневрита). Это заболевание в конце 19 века было широко распространено в Восточной Азии. Традиционной пищей для жителей этого региона является рис. Издревле население употребляло так называемый чёрный рис, т.е. не очищенный от оболочки. Но европейцы, участвующие в экономическом освоении региона, употребляли белый, очищенный (полированный) рис. Следом за ними белый рис стали есть и аборигены (мы что, хуже?). И... стали заболевать. Симптомы были тяжёлыми - невралгия, отеки, ослабление кровообращения. В конечном итоге неведомая болезнь приводила к смерти - вымирали целые деревни. Многочисленные попытки разгадать тайну этой болезни ни к чему не привели.

Причину её в 1889 году обнаружил тюремный врач из Батавии (Индонезия) Христиан Эйкман. Он заметил, что больные бери-бери домашние птицы, которым давали чёрный рис (заключённые отказывались его есть), выздоравливали. После многочисленных опытов он сделал вывод, что в оболочках рисовых зерен содержится какой-то элемент (элемент В, как назвал его Эйкман). Стало понятным, почему бери-бери не болели европейцы - их пища была более разнообразной, и необходимое вещество содержалось в других продуктах.

В начале 20 века директор Листеровского института в Лондоне Ч. Мартин поручил молодому польскому химику Казимиру Функу выделить в чистом виде вещество, которое излечивает бери-бери. Изучив литературу и проделав кое-какие предварительные опыты, Функ решил, что это неведомое вещество должно по составу походить на амины. Значит и методы выделения нужно применить соответствующие. И вот в 1911 году он выделил из рисовых отрубей бесцветное кристаллическое вещество, которое, будучи добавленным в ничтожных количествах в корм, приводило к излечению голубей, больных бери-бери.

Это вещество (витамин $\mathrm{B}_{1}$, или тиамин, регулирующий углеводный обмен) содержало аминогруппу и обладало некоторыми свойствами аминов. Поэтому Функ назвал его «витамин», от латинских «вита» - жизнь, и «амин», т.е. «жизненный амин». И хотя впоследствии были обнаружены вещества сходного действия, но никакого отношения к аминам не имевшие, это название закрепилось за ними и используется по сию пору.

Витамины - низкомолекулярные вещества, оказывающие каталитические, регулирующие функции, требующиеся в очень небольших количествах.

Все витамины обычно делят по растворимости в воде или в жирах.

К жирорастворимым витаминам относят витамины А (ретинол), D (кальциферол), Е (токоферол) и К (филлохинон). Группа водорастворимых витаминов включает витамины группы В, витамин С (аскорбиновая кислота), витамин Н (биотин), витамин Р (рутин), витамин РР (никотиновая кислота).

Среди растений Приморья есть немало витаминоносных растений.

Ретинол в растительных продуктах отсутствует, но в них имеется бета-каротин, который уже в организме человека превращается в витамин А. Довольно много каротина, кроме моркови, содержится в плодах шиповника, рябины (семейство Розовые), облепихи (семей- 
ство Лоховые), т.е. обычно в растениях с красными и жёлтыми плодами. Кроме того, каротин есть в некоторых бобовых (клевер, люцерна) и мятликовых (мятлик, тимофеевка).

Кальциферола в растениях мало, основные поставщики его в виде эргокальциферола (Д2) - рыбий жир, жирная рыба, молоко, яйца. Зато в растениях (обычно ассоциированных с грибами - злаках, например) имеются провитамины (эргостерин, стигмастерин, ситостерин), которые под действием солнечного света превращаются в холекальциферол (Д $)_{3}$.

Витамина Е много в зародышах злаков (в промышленности его получают из пшеницы), плодах облепихи. Следует отметить, что в процессе термической обработки (при производстве хлеба) содержание токоферола уменьшается на $90 \%$.

К источникам витамина К относится зелень, крапива, белокочанная и цветная капуста, брокколи, оливковое масло, творог, молоко. Восполнить норму витамина можно вместе с пшеничными отрубями, злаками и фруктами. Полезно употреблять в пищу киви, бананы и авокадо. Витамин К самостоятельно синтезируется в человеческом организме. Например, часто его источником становится кишечная палочка в толстой кишке.

Витамин С в больших количествах содержится в плодах шиповника даурского из семейства Розовые (пяти его плодов достаточно для восполнения суточной дозы витамина для человека) и актинидии (семейство Актинидиевые), хвое сосны и пихты (семейство Сосновые). Много его в околоплоднике незрелого ореха маньчжурского (семейство Ореховые), листьях пастушьей сумки (семейство Капустовые), надземных частях горца птичьего (семейство Гречиховые), крапивы (семейство Крапивовые), звездчатки средней (семейство Гвоздиковые). В годы Великой Отечественной войны советовали употреблять листья звездчатки для предотвращения цинги. А крапива - вообще кладезь витаминов. В ней находили, помимо аскорбиновой кислоты, каротин, витамины $\mathrm{B}_{1}, \mathrm{~B}_{2}, \mathrm{~K}, \mathrm{E}, \mathrm{PP}$ и множество других полезных веществ.

\section{Гликозиды}

Гликозиды и последующие рассматриваемые нами вещества относятся к веществам вторичного происхождения. Они не накапливаются в растениях в значительных количествах, являясь промежуточными продуктами метаболизма, однако оказывают выраженное физиологическое действие на организм человека.

Молекула гликозида состоит из двух компонентов - углевода (моно- или чаще дисахарида) и неуглеводной части (так называемого агликона, «не сахара» в переводе с греческого). В качестве агликона выступают самые разные соединения (кислоты, спирты, амины, фенолы и др.), которые и обеспечивают соответствующую биологическую активность гликозида.

Существуют различные группы гликозидов, которые классифицируются по их действию, химической природе агликона или связи сахара и агликона.

Так, известна обширная группа сердечных гликозидов, в качестве агликона имеющих стероиды и оказывающих действие на сердечно-сосудистую систему. Они имеются в ландыше Кейзке (семейство Ландышевые), адонисе амурском (семейство Лютиковые).

Цианогенные гликозиды при гидролизе образуют ядовитую синильную кислоту. Наиболее известным из них является амигдалин, содержащийся в семенах многих косточковых семейства Розовые - абрикоса, сливы, черёмухи и др. Наличие синильной кислоты легко определяется по своеобразному запаху горького миндаля. Уже 0,05 грамма синильной кислоты являются смертельными для человека - это всего 50-60 граммов семян! Тем не менее умеренное употребление семян косточковых рекомендуют как противораковое средство. 
Слабительное действие оказывают антрагликозиды, обнаруживаемые в горце (полигонин), ревене (реохризин), из семейства Гречиховые, крушине из одноимённого семейства (франгулин). В качестве агликона в них фигурирует ароматическое соединение антрахинон или его производные.

В горечавке из одноимённого семейства, полыни, одуванчике (семейство Астровые) содержатся гликозиды, придающие этим растениям горечь. Они способствуют повышению аппетита, усиливают перистальтику желудка, увеличивают «выход» желудочного сока.

В растениях семейств Капустовые, реже Луковые имеются тиольные гликозиды, придающие им жгучий вкус и обладающие антимикробным действием. В таких гликозидах сахар связан с агликоном серой. Примеры - синигрин и синальбин, содержащиеся в горчице, хрене.

Еще одна группа гликозидов - сапонины, названные так потому, что способны давать пенящиеся растворы («сапо» по-латыни означает мыло). Агликон сапонинов стероидной или тритерпеноидной природы. Гликозиды обладают отхаркивающим (солодка из семейства Бобовые), успокаивающим (синюха из одноименного семейства) действием. Наличие сапонинов характерная черта растений семейства Гвоздиковые. Даже названия некоторых из них - мыльнянка, «мыльный корень» (народное «имя» зорьки) говорит об использовании их в качестве суррогата мыла. Довольно много (до 8\%) сапонинов в корневищах диоскореи ниппонской из одноимённого семейства. Это небольшая травянистая лиана до 3 м высоты, растущая по дубнякам и долинным лесам, является известным лекарственным растением - её препараты сдерживают развитие атеросклероза, понижают артериальное давление, стимулируют деятельность желудочно-кишечного тракта.

Стероидные гликозиды обнаружены в некоторых видах рода купена (семейство Ландышевые). Растения рода широко используются в официальной и народной медицинах различных стран Евразии и Америки, проявляя ранозаживляющие, кардиотонические, тонизирующие свойства.

В различных органах растений семейства Паслёновые (паслён, картофель) содержатся соланины. Они обладают ядовитыми свойствами (сами растения при этом приобретают фунгицидные и инсектицидные свойства), поэтому пролежавшие на свету клубни картофеля, которые становятся несколько позеленевшими, употреблять в пищу нельзя - в них резко возрастает содержание соланина. Тошнота, рвота, боли в животе, диарея - типичные симптомы отравления соланином. Именно из-за ядовитости надземных частей (отведавшие их животные умирали) томаты, например, долгое время выращивались лишь в оранжереях. Да и картофель не сразу попал на столы европейцев, которые до 19 столетия считали, что он вызывает проказу и золотуху.

Тритерпеновые гликозиды - обширная группа химических веществ, обладающая большим спектром лечебного действия - адаптогенным, противоопухолевым, тонизирующим, иммуномодулирующим и рядом других. Возможно, самыми известными растениями Приморья, содержащими эти вещества, являются представители семейства Аралиевые. Как правило, гликозиды и называются по латинским именам растений, в которых находятся - у женьшеня настоящего это гинсенозиды, у аралий - аралозиды, у элеутерококка - элеутерозиды. У женьшеня гинсенозиды концентрируются в паренхимных тканях, больше всего накапливаясь в мелких придаточных корнях. Именно поэтому копатели женьшеня в старину тщательно и осторожно извлекали корень из почвы, стараясь не повредить даже мельчайшие корни. 
Антоциановые гликозиды придают растениям красный, синий, фиолетовый цвет и по химическому строению близки к флавоноидам. Подобно флавоноидам, они повышают эластичность капилляров, обладают противовоспалительным действием, кроме того, используются при некоторых глазных заболеваниях, повышая остроту зрения, как, например, антоциановые гликозиды черники. В чернике встречается также арбутин - один из фенольных гликозидов, содержащийся также в бруснике, толокнянке и в других растениях семейства Вересковые и обладающий дезинфицирующим действием.

Кумариновые гликозиды включают в себя в качестве агликона производные кумарина и встречаются в растениях семейств Капустовые, Бобовые, Мятликовые. Чистый кумарин тврдое ароматическое вещество, от которого зависит запах цветков многих растений. Довольно много кумарина в различных частях таких бобовых, как донники лекарственный и ароматный. Если растереть листья этих растений, можно сразу почувствовать своеобразный, довольно резкий запах кумаринов. Стоит отметить, что эти вещества снижают свертываемость крови, оказывают и другие терапевтические эффекты. Настойка на зубровке душистой из мятликовых, производимая в Польше, Белоруссии и России под сходным наименованием «Зубровка», содержит кумарины, которые не только придают ей характерный вкус, но и улучшают аппетит, а также способствуют эффективному перевариванию пищи.

Совместно с гликозидами в тканях растений как правило присутствуют и ферменты, их расщепляющие, поэтому растения, содержащие гликозиды, рекомендуется быстро сушить при температуре не выше $60^{\circ} \mathrm{C}$, а затем сохранять в сухом, хорошо проветриваемом помещении.

Как правило, местом накопления гликозидов являются те органы растений, в которых интенсивно протекает обмен веществ. Определяющее условие образования и накопления этих физиологически активных веществ - хорошая освещённость. Обильное азотное питание снижает содержание гликозидов в органах растений.

\section{Фенольные соединения и хиноны}

Фенольные соединения - обширная группа химических соединений, имеющих в своём составе ароматические (бензольные) кольца, несущие одну или несколько гидроксильных групп. Их роль в жизнедеятельности растений многообразна. Фенолы участвуют в энергетических процессах, темновых реакциях фотосинтеза, играют защитную роль при механических повреждениях и обеспечивают устойчивость к заболеваниям.

Различных фенольных соединений в растениях немало. К ним относятся, например, флавоноиды - в плодах и ягодах содержатся катехины, окраску плодов, листьев, лепестков от розовой до чёрно-фиолетовой обеспечивают антоцианы, флавоны и флавонолы - жёлтые красящие вещества.

Кроме мономерных фенольных соединений встречаются и полимерные. Из них рассмотрим дубильные вещества и лигнин.

Дубильные вещества (танины) получили своё название по способности дубить невыделанную шкуру, превращая её в кожу и придавая свойство водонепроницаемости. Раньше для этой цели использовали кору дуба (а также дубовые галлы), а потому и вещества получили название дубильных, а сам обработку кожи - дублением.

Дубильные соединения содержатся в различных органах растений, но преимущественно в коре и древесине деревьев и кустарников, а также в корнях и корневищах различных травянистых растений (дуб, берёза, черёмуха, зверобой, полынь, ревень, черника, пиж- 
ма). В листьях дубильные вещества, или танниды, обнаружены в клетках эпидермы и паренхимы, окружающих проводящие пучки и жилки, а в корневищах и корнях они накапливаются в паренхиме коры и сердцевинных лучах.

Дубильные вещества обычно малотоксичны. Растения, содержащие дубильные вещества, применяют как вяжущие и бактерицидные средства. Противовоспалительный эффект дубильных соединений основан на взаимодействии с ними белков. В результате такого взаимодействия на слизистых оболочках, например, образуется защитная пленка, препятствующая дальнейшему развитию воспалительного процесса; такая же пленка возникает на обожжённых местах, поранениях, обработанных таннидами. Это обуславливает кровоостанавливающее и противовоспалительное действие.

Кроме того, танниды применяются при отравлении алкалоидами и солями тяжёлых металлов. Дубильные вещества при взаимодействии с кислородом воздуха окисляются и переходят в вещества, окрашенные в тёмно-бурый или красно-бурый цвет, нерастворимые в воде (отсюда и побурение разрезанных яблок, айвы, картофеля, редиса и др.).

Дубильные вещества содержатся и во многих других растениях - в основном в небольших количествах, но много их накапливается в плодах черёмухи азиатской (семейство Розовые), корневищах бадана тихоокеанского из семейства Камнеломковые (около 24\%).

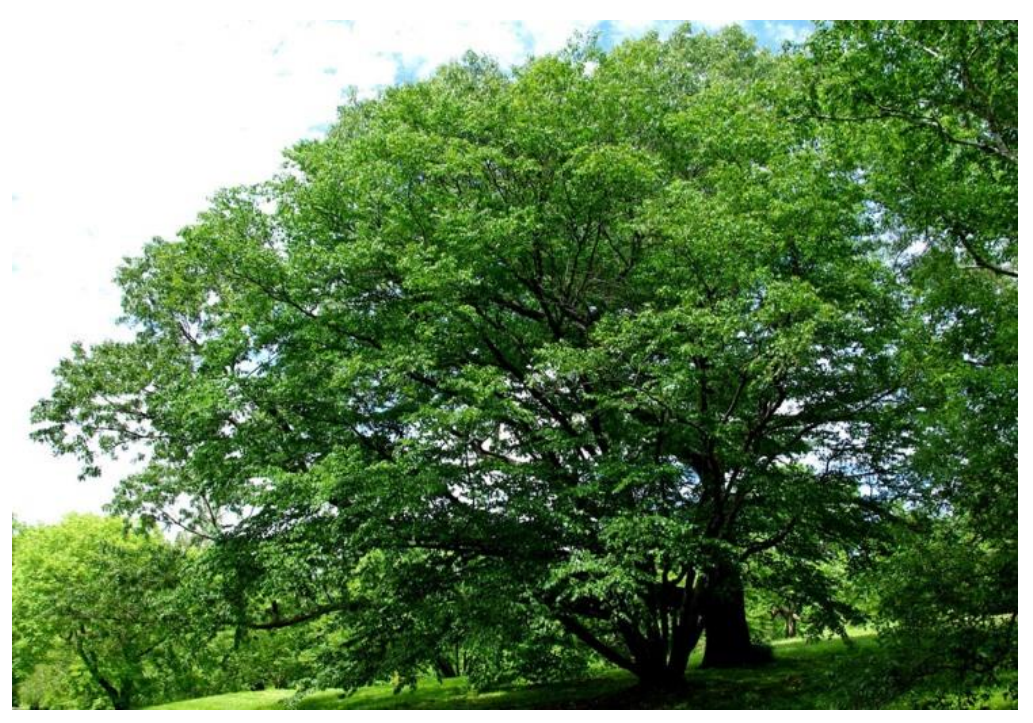

Береза Шмидта (https://upload.wikimedia.org)

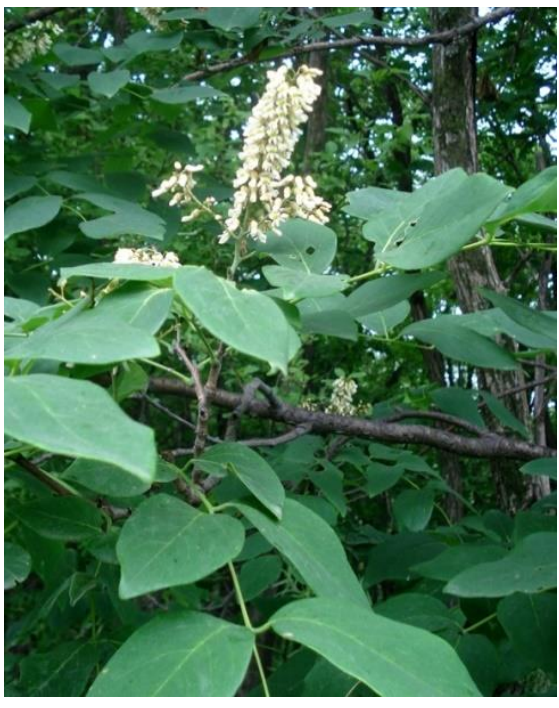

Маакия амурская

Весьма интересный тип полимерных фенольных соединений - лигнин. Он входит в состав оболочки клеток растений, делая её еще более прочной. Если это древесные растения - то чем его больше, тем прочнее и тяжелее древесина. В растениях лигнин - конечный продукт, весьма инертный, поэтому выполняющий лишь механические функции. Разрушить его могут только микроорганизмы.

Лигнин придает надземным осевым органам (стеблю, стволу) прочность и делает возможным рост в вертикальном направлении. Благодаря лигнину появились древесные растения.

Содержание лигнина в растениях различно. Среди деревьев Приморья (а также всего Дальнего Востока) самую твёрдую древесину имеет берёза Шмидта (семейство Берёзовые), которая растёт на крайнем юге Приморского края. Даже в сухом состоянии она тонет в воде. По твёрдости она близка к таким деревьям как бакаут (семейство Парнолистниковые) и самшит (семейство Самшитовые), твёрдость древесины которых хорошо известна. 
Жители Хасанского района Приморья издавна применяли берёзу Шмидта для изготовления осей телег и жерновов, даже стиральных досок. В предвоенные годы из этой берёзы делали подшипники, которые служили дольше чугунных. Если древесину берёзы выдержать долгое время в воде, то она становится еще твёрже и приобретает чёрный цвет.

Ещё одна интересная группа химических соединений, содержащихся в растениях полифенолы. Это целая группа различных соединений - флавоноидов, кумаринов, лигнанов и др. Они являются природными антиоксидантами, способны связывать свободные радикалы, тем самым предупреждая развитие широкого спектра заболеваний - от онкологических до болезней сердечно-сосудистой системы.

В последнее время активно изучаются растения, проявляющие антиоксидантную активность. Среди наиболее перспективных - виноград амурский, представители бобовых леспедеца двуцветная и маакия амурская. На основе полифенольного комплекса маакии амурской был разработан гепатопротективный препарат «Максар» (аббревиатура фамилий руководителей коллективов-разработчиков О.Б. Максимова и А.С. Саратикова) весьма эффективного действия, используемый при токсических поражениях печени.

Хиноны представляют собой циклические органические соединения неароматического характера. По своему строению это ненасыщенные сопряжённые циклические дикетоны, отличающиеся друг от друга положением карбонильных групп, а также наличием различных радикалов. Хиноны широко представлены в природе, часто встречаются в растениях, хотя и не только. Это такие вещества, как бензохиноны, нафтохиноны, а также т.н. высшие хиноны.

В основе молекул нафтохинонов лежит нафталин. Эти соединения, общим числом более 200, найдены более чем в двадцати семействах высших растений (Ореховые, Бурачниковые, Росянковые и др.).

Так, во многих бурачниковых (гакелии, синяке, липучке и др.) содержится нафтохинон шиконин. Довольно много шиконина накапливается в корнях воробейника краснокорневого - травянистом многолетнике, растущем по сухим каменистым склонам и зарослям кустарников в долинах рек. Он концентрируется в пробковом слое корней растения, придавая им характерный красно-фиолетовый цвет. Воробейник - известное в Восточной Азии лекарственное растение, использовавшееся, кроме того, и для получения красителя, в основе которого также лежит шиконин. Препараты растения применялись для лечения заболеваний кожи, в качестве противовоспалительного, ранозаживляющего, противомикробного средства. В настоящее время учёными Дальневосточного отделения Академии наук предложен биотехнологический способ получения шиконина, позволяющий получать до 14\% его эфиров. Разработано лекарственное средство «Масло шикониновое», оказывающее эффективное противовоспалительное действие.

Другой представитель нафтохинонов - юглон, содержащийся в орехе маньчжурском (семейство Ореховые). Он, кстати, придаёт своеобразный довольно сильный «иодный» запах околоплоднику. Юглон подавляет рост бактерий и грибов и поэтому используется растением как защитное средство. Этот нафтохинон применяется как пищевой консервант, причём действие его длится до двух месяцев, после чего он разлагается.

Больше всего хинонов относится к группе антрахинонов. Они найдены в таких семействах, как Мареновые, Гречиховые, Жёстеровые и др., накапливаются главным образом в ядровой древесине, коре, корнях и корневищах. Антрахиноны придают окраску растениям, используются как природные красители, а также в медицине, оказывая слабительное, противогрибковое, противовирусное действие. 
В Приморье в самых разных местообитаниях, от лесов до обочин дорог, часто встречается марена сердцелистная, многолетник до двух метров высоты с красноватым корневищем. Это традиционное лекарственное растение восточной медицины, используемое при заболеваниях печени, для удаления почечных камней и проявляющее противоопухолевые и противовирусные свойства. В состав корней марены входят антрахиноны пурпурин и муньистин. Важно, что эти соединения не обладают мутагенной активностью, характерной для других антрахинонов.

\section{Алкалоиды}

Алкалоиды - гетероциклические химические соединения, имеющие в своём составе азот. Для алкалоидов, общее число которых уже перевалило за десяток тысяч, характерны свойства оснований (само их название переводится как «похожий на щёлочь») - с кислотами они дают соли. И встречаются в растениях они в виде солей органических кислот - лимонной, яблочной, винной и др., которые являются водорастворимыми, в то время как чистые алкалоиды растворяются в органических растворителях.

В растениях алкалоиды представляют собой не только продукты обмена веществ, они участвуют в различных синтетических и других процессах, например, прослежена связь никотина с азотистым питанием. Однако окончательно роль алкалоидов в жизнедеятельности растений не выяснена.

Алкалоиды оказывают выраженное действие на нервную систему животных и человека, причём в небольших дозах они возбуждают её действие, а в больших - угнетают. Многие алкалоиды - известные яды. Достаточно вспомнить кураре; сок растений, его содержащих, южноамериканские индейцы использовали для смачивания стрел на охоте.

Содержание алкалоидов в растениях обычно невелико и составляет десятые и сотые доли процента. Богатые алкалоидами растения содержат их от одного до трёх процентов. Содержание алкалоидов в растительных тканях меняется в зависимости от географического положения растений (их больше во влажных тропиках), от температуры (при её снижении падает), высоты над уровнем моря, типа почвы и даже времени суток. Как правило, в растении одновременно встречаются много алкалоидов - до нескольких десятков.

Рассмотрим некоторые наиболее известные алкалоиды, встречаемые в растениях Приморского края.

Эфедрин - алкалоид, содержащийся в представителях рода хвойник (эфедра) из семейства Хвойниковые. Он действует как стимулятор, вызывая ускоренное сердцебиение и поднимая кровяное давление, расширяя бронхи. Эфедрин входит в состав лекарственных средств, используемых при бронхиальной астме, пониженном давлении, при отравлении снотворными. В то же время он вызывает привыкание, поэтому является наркотиком. В Приморье растёт один вид рода - хвойник односемянный. Это небольшой, до 30 см высоты, кустарник, стволик которого погружен в субстрат, а на поверхность выходят многочисленные тонкие желтоватые веточки, прямостоячие или стелющиеся. Женские шишки, красные, ягодообразные, супротивно расположенные, содержат по одному семени. Это растение весьма редкое, внесено в Красную книгу Приморского края и охраняется в Лазовском заповеднике. Произрастает по песчаным речным дюнам, на скалах у моря. 

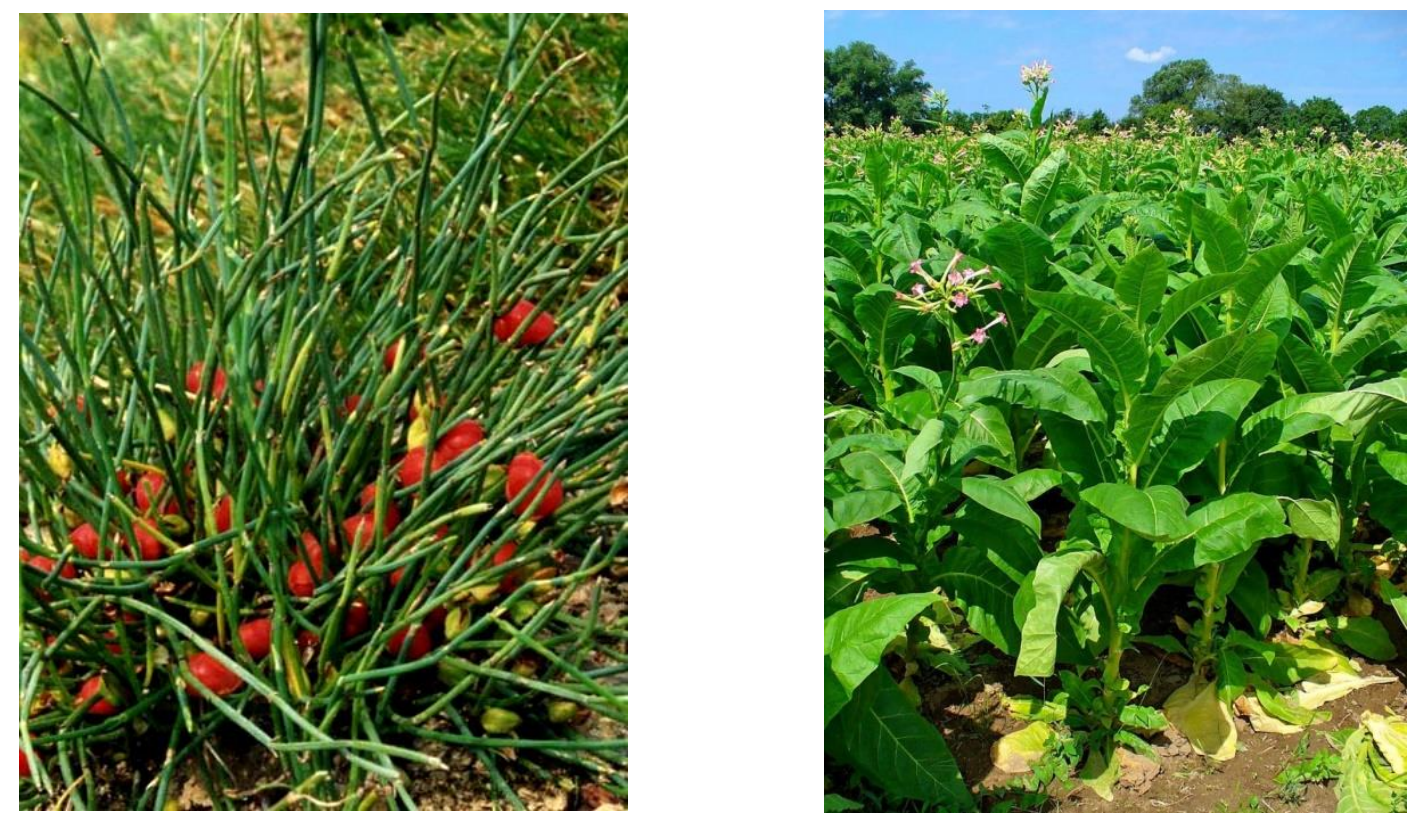

Хвойник односемянный (https://wikipedia.org) Табак настоящий (https://wikipedia.org)

Никотин содержится в целом ряде растений, в основном семейства Паслёновые. Больше его накапливается в растениях рода табак. В Приморье иногда выращивается табак настоящий - крупный, до полутора метров, травянистый многолетник с очередными цельнокрайними листьями и белыми цветками. Впервые никотин был выделен немецкими химиками В. Посселтом и К. Райманном в 1828 году. Поступив в кровь, никотин возбуждает центры удовольствия, способствует выбросу адреналина, но вскоре распадается, что вызывает необходимость поступления следующей его порции. В результате возникает никотиновая зависимость - одна из наиболее трудно искореняемых наркоманий. При отравлении никотином наступает смерть от паралича дыхания. Смертельная доза для человека - около 50 мг. С каждой сигаретой в организм поступает около 1,5 мг никотина - нужно сразу выкурить больше тридцати сигарет, чтобы это привело к летальному исходу. Поэтому правильно говорят, что капля никотина убивает лошадь - в капле содержится примерно 1 г никотина, который убьёт не один десяток человек.

Морфин - алкалоид, содержащийся в представителях рода мак из одноимённого семейства. Это первый алкалоид, который был получен человеком в чистом виде. В 1804 году немецкий фармаколог Ф. Сертюрнер выделил из опиума действующее вещество и назвал его морфием по имени греческого бога сновидений Морфея (уже позднее французский химик Гей-Люссак предложил для него современное название). Почему именно Морфея? Еще со времён Древнего Египта была известна практика использования мака для успокоения плачущих детей. Впоследствии мак стал символом сна и забвения. Морфин обладает выраженным болеутоляющим действием, понижая возбудимость болевых центров. Кроме того, он вызывает эйфорию, что толкает людей на повторное употребление. К сожалению, частое использование морфина приводит к привыканию. Морфинизм как вид наркомании довольно широко распространен на Земле. В Приморье произрастают три вида мака - амурский, голостебельный и аномальный. Последний вид внесен в Красную книгу Приморского края.

В различных частях аконитов (борцов) из семейства Лютиковые содержатся алкалоиды группы аконитина. Аконитин считается одним из самых сильных и быстро всасывающихся ядов. Не зря само растение, аконит, согласно греческой мифологии, считался порож- 
дением ядовитой слюны, которую стал испускать трёхглавый Цербер, страж адских ворот, взбешённый тем, что Геракл вытащил его из ада. Смертельная доза чистого аконитина для человека составляет 100 микрограммов на один килограмм веса. Он хорошо всасывается через пищеварительный канал. Аконитин возбуждает, а затем парализует окончания чувствительных нервов, оказывая рефлекторное влияние на сердце и органы дыхания. Смерть наступает от паралича дыхательного центра, причём в зависимости от дозы она может наступить через несколько минут. Аконитин быстро разлагается в организме. Образовавшиеся при этом метаболиты из организма выделяются с мочой. В Приморье произрастают 17 видов аконита.

В семейство Сельдереевые входят два вида, встречающиеся и в Приморье, широко и давно известные как очень ядовитые растения - болиголов пятнистый и вех ядовитый.

По сорным местам, у дорог можно изредка встретить высокое, до двух с половиной метров высоты растение, которое можно легко узнать и запомнить по стеблю, покрытому многочисленными красно-коричневыми пятнышками. Это болиголов пятнистый, вид для Приморья заносной. В болиголове содержится алкалоид кониин. Выделен он в 1881 году из корня болиголова немецким химиком А. Гофманом. В чистом виде это бесцветная жидкость с запахом мышиной мочи. Кониин содержится во всех частях растения, но больше всего его в незрелых плодах, в которых сумма алкалоидов составляет $2 \%$. Кониин - первый из природных алкалоидов, который в 1886 году был синтезирован искусственно немецким химиком А. Ладенбургом. Смертельная доза кониина для человека - 0,15 грамма.

Препаратами болиголова в Древней Греции лишали жизни приговоренных к смерти; им, в частности, был умерщвлён знаменитый древнегреческий философ Сократ. Печальную эстафету у греков приняли римляне. Для облегчения страданий приговоренным давали не чистый сок болиголова, а его смесь с опием.

Не только ядовитостью известен болиголов с древности. Как и многие другие ядовитые растения, он одновременно является и лекарством от раковых заболеваний.
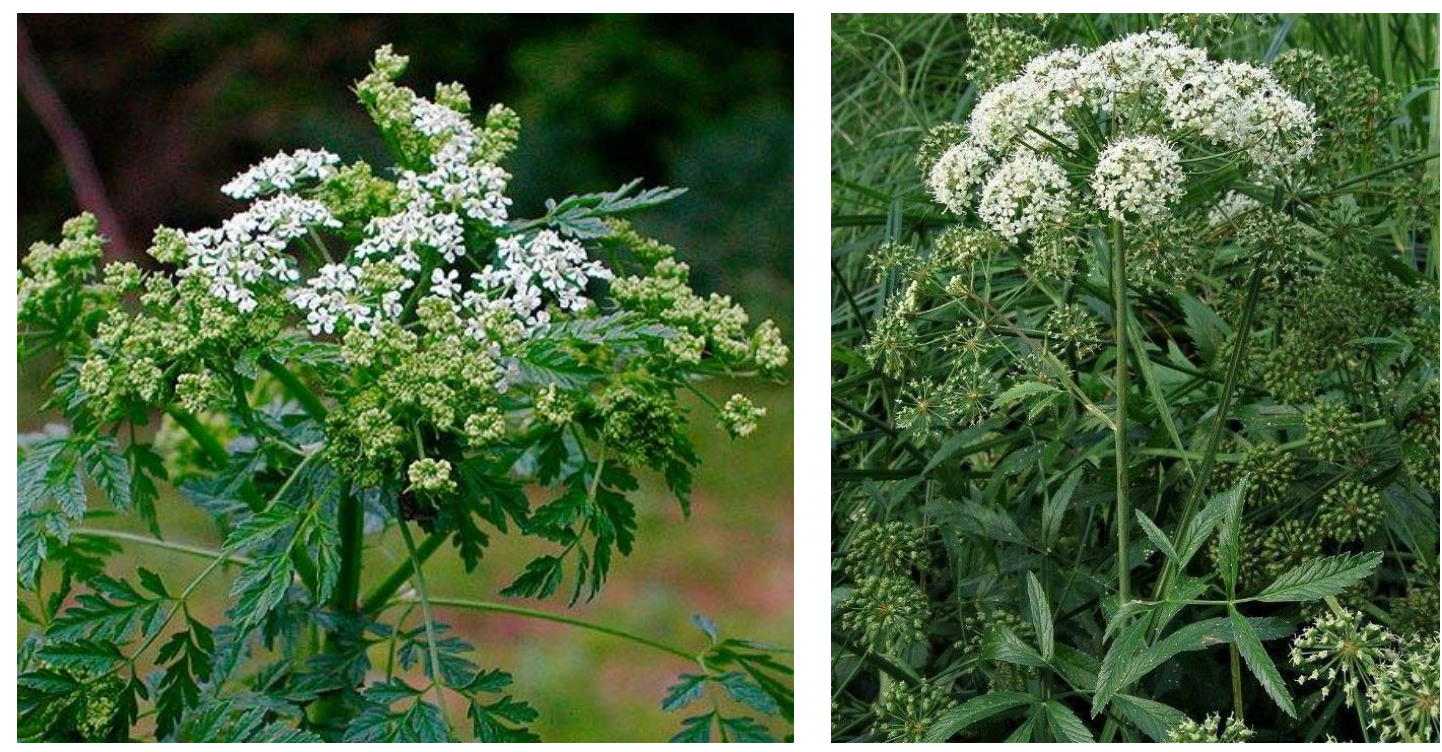

Болиголов пятнистый (https://wikipedia.org) Вех ядовитый (https://i.pinimg.com)

Кониин оказывает сходное действие с аконитином. При отравлении кониином смерть наступает от паралича дыхания. А отравиться им можно и случайно - спутав листья болиго- 
лова с листьями петрушки или употребив корень вместо хрена. Были случаи и ошибочного использования его плодов вместо плодов аниса.

Другое, не менее ядовитое растение этого же семейства, - вех ядовитый, или цикута. По внешнему виду он похож на болиголов, но поскромнее (до метра и чуть более высоты), его стебли не имеют пятен. Да и растёт по сырым местам - в канавах, по болотистым берегам рек. Характерная особенность веха - наличие в стеблекорне нескольких полостей, или камер, в которых находится желтоватый сок, содержащий алкалоиды, главный из которых - цикутотоксин. Признаки отравления у человека: головная боль, рвота, боли в животе, озноб, слюнотечение, судороги. Смерть наступает в результате остановки дыхания и угнетения сердечной деятельности. И хотя смертельная доза цикуты для человека не установлена, она, также как и болиголов, издавна использовалась в качестве «официального» яда. До сих пор историки спорят, каким же растением был отравлен Сократ - болиголовом или вехом.

Атропин - алкалоид, содержащийся преимущественно в растениях семейства Паслёновые - белене чёрной, дурмане вонючем. В Приморье это заносные растения, произрастающие по сорным местам. Но более известно другое растение семейства, в котором имеется атропин. Это красавка, или белладонна, в Приморье не встречающаяся. Само название алкалоида происходит от родового наименования красавки (Atropa). Любопытно и происхождение латинского видового эпитета belladonna - оно восходит к итальянскому «белла донна» прекрасная дама (а отсюда и русское название красавка). Почему? Дело в том, что одним из критериев женской красоты в Древнем Риме являлись широкие зрачки. Вот и использовали красавицы-римлянки сок белладонны - при его употреблении глаза становились большими, наполнялись выразительным блеском, а на щёчках появлялся румянец. Увы, после длительного использования атропин приводил к слепоте, а случайное проглатывание могло спровоцировать смерть. Но чего не сделаешь ради красоты? Сегодня атропин применяют для стимуляции дыхания, для лечения воспалительных заболеваний глаз. Атропин был впервые выделен в 1831 году немецким ботаником и физиологом Ф. Мейном.

Гиосциамин - алкалоид, содержащийся в белене чёрной (семейство Паслёновые). Это изомер атропина, встречаемый также в белладонне, дурнишнике (семейство Астровые). В Приморье белена встречается по сорным местам. Это однолетнее или двулетнее растение чуть более метра высотой, с перистонадрезанными листьями и желтоватыми цветками. При отравлении беленой речь человека становится бессвязной, ухудшается координация, наступает психическое беспокойство; с давних пор дошло до нас выражение «белены объелся»так говорят о беспричинно возбужденных людях.

Протовератрин, иервин - алкалоиды, содержащиеся в чемерице из семейства Мелантиевые. В Приморье по лугам, в лесах различного типа произрастает ряд видов чемерицы. Сумма алкалоидов чемерицы Лобеля снижает кровяное давление, одновременно значительно увеличивая амплитуду сердечных сокращений; раздражает окончания чувствительных нервов, вызывает сильное чихание и кашель.

Секуринин - алкалоид, содержащийся в секуринеге полукустарниковой из семейства Молочаевые. В Приморье этот раскидистый кустарник произрастает по каменистым осыпям, скалам на юге и в западной части края. Секуринин возбуждает центральную нервную систему, повышает рефлекторную возбудимость спинного мозга. По характеру действия он близок к стрихнину, но менее активен, хотя одновременно и менее токсичен (в 8-10 раз). Его применяют при астенических состояниях, парезах и параличах, возникших после перенесенных инфекционных и других заболеваний, при неврастении, половом бессилии на почве функциональных нервных расстройств и др. 
Берберин - алкалоид, широко представленный в растениях Приморья. Он содержится в барбарисе амурском (семейство Барбарисовые), бархате амурском (семейство Рутовые), луносемяннике даурском (семейство Луносемянниковые) и др. Берберин снижает артериальное давление, ослабляет сердечную деятельность, вызывает сокращение гладкой мускулатуры матки и кишечника, усиливает отделение желчи. Применяют его для лечения лейшманиоза и малярии, а также как желчегонное средство.

Ликоподин - содержится в числе прочих алкалоидов в надземных частях баранца обыкновенного (семейство Баранцовые). Это небольшой, до 20 сантиметров, представитель плаунов, встречающийся на самом севере Приморья по влажным лесам, зарослям кедрового стланика. Он оказывает существенное воздействие на функциональное состояние вегетативной нервной системы и процесс нервно-мышечной передачи, что приводит, в частности, к снижению артериального давления у пациентов, страдающих гипертонией. Ликоподин регулирует солевой обмен, который нарушается в процессе склерозирования сосудов (особенно у старых животных). В этой связи он является прекрасным гериатрическим средством.

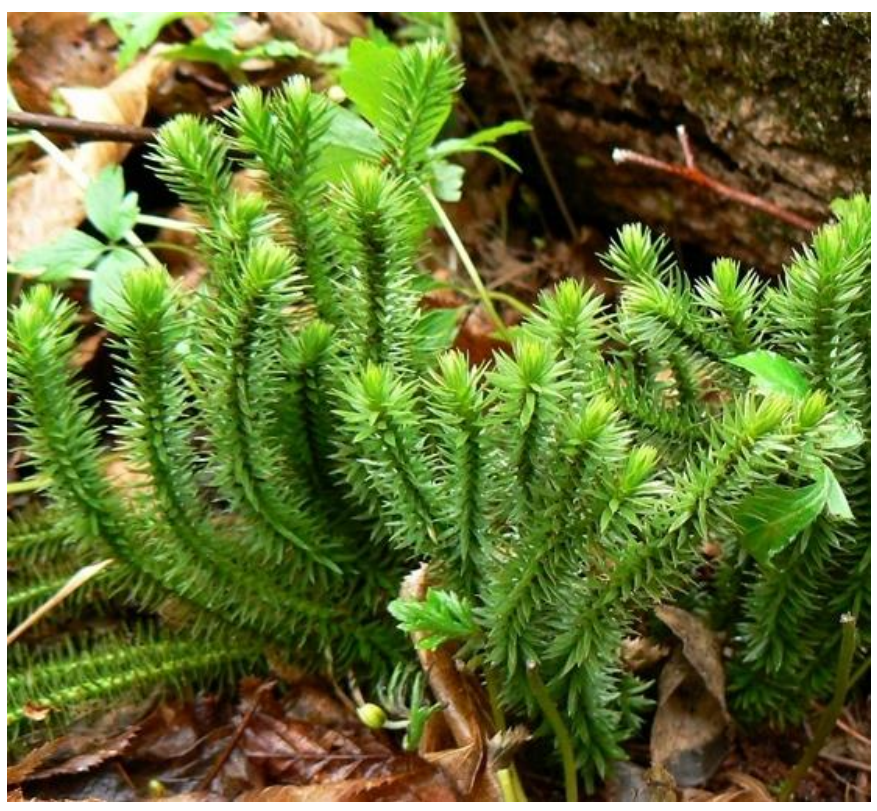

Баранец обыкновенный (https://wikipedia.org)

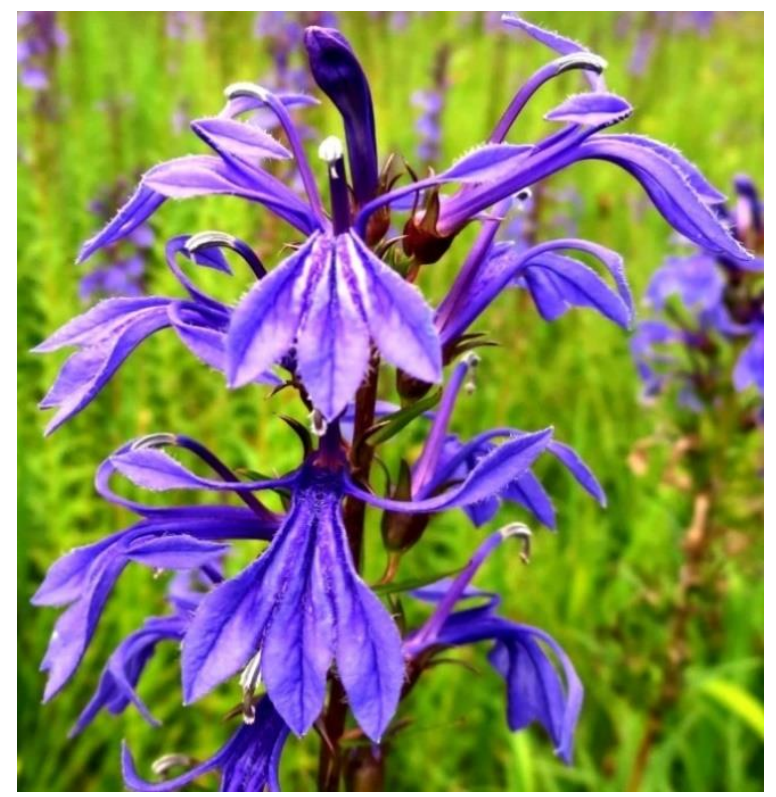

Лобелия сидячелистная (https://www.lekrs.ru)

У растений порядка Гвоздикоцветные содержатся беталаины - единственные алкалоиды, имеющие яркую окраску и заменяющие антоцианы (кроме растений семейства Гвоздиковые). Одни из них - бетацианины - придают красно-фиолетовую окраску, например, свёкле (семейство Маревые), другие - бетаксантины - жёлтую.

Лобелин - алкалоид, содержащийся в лобелии сидячелистной из семейства Колокольчиковые. Это довольно крупное, до метра высоты растение с неправильными синими цветками, произрастающее по болотам и болотистым лугам. Алкалоид (точнее, его препараты) используется для стимулирования дыхания при коклюше и астме. 


\section{Эфирные масла и смолы}

Эти вещества содержатся во многих растениях. Их общей чертой является нерастворимость в воде, однако они хорошо растворяются в органических растворителях. В растениях они локализованы в особых структурах - железистых волосках, вместилищах, смоляных ходах.

Многие растения в качестве продуктов обмена имеют эфирные масла - ароматические летучие вещества, из-за чего они и получили своё название. Эфирные масла легко перегоняются из растительного сырья горячей водой или паром. Несмотря на то, что они называются маслами (выделенные в чистом виде, они действительно имеют вид маслянистой жидкости), от жирных масел их отличает химический состав. Эфирные масла - не индивидуальные соединения, это целый комплекс различных веществ - терпенов, терпеноидов, спиртов, альдегидов и др. Среди них преобладают терпены - вещества, имеющие в своём составе десять атомов углерода с общей формулой $\mathrm{C}_{10} \mathrm{H}_{16}$.

Все терпены делятся на алифатические и циклические. Основой алифатических терпенов является изопрен, производными которого являются каучук, гуттаперча, каротиноиды. Для растений наиболее важны кислородсодержащие алифатические терпены - линалоол, цитронеллол, гераниол и др. Линалоол можно найти в цветках ландыша из одноимённого семейства, а его сложные эфиры (муравьинокислый, уксуснокислый и др.) обуславливают аромат персиков. Гераниол и цитролнеллол - основные компоненты розового масла. Бурокрасное эфирное масло с приятным ароматом содержится в корневищах гравилата алеппского (семейство Розовые). В его состав входит евгенол, придающий запах гвоздики, из-за чего растение называют «гвоздичным корнем», и использовали в качестве пряности - заменителя гвоздики.

Такие циклические терпены, как лимонен и карвон, содержатся в эфирном масле тмина и укропа; ментол - основной компонент масла перечной мяты; камфен, борнеол входят в состав пихтового масла. Последнее соединение при окислении образует камфору, которая имеется в эфирном масле многих растений.

Об одном из циклических терпенов - таксоле (паклитакселе) хочется сказать особо. Ещё в 1963 г. в США стартовала программа поиска веществ, обладающих противораковой активностью. Уникальным оказался таксол, полученный из коры тиса тихоокеанского (семейство Тисовые). Он препятствовал работе микротрубочек, участвующих в расхождении хромосом при делении клеток, вследствие чего опухоль прекращала рост. Однако содержание его в растительном материале очень уж небольшое - менее $0,001 \%$ ! А тис - не столь уж распространённое растение. Поэтому потребовался химический синтез таксола, формулу которого установили лишь к 1971 г. Но и здесь возникли трудности - при всех способах синтеза выход таксола составляет лишь около 2-4\%. Есть таксол и в коре нашего тиса остроконечного; кроме того, в клеточной культуре тиса были найдены и другие вещества противоопухолевого действия - дитерпеноиды юннаксан, таксюннанин, юннанксан.

Образуются и накапливаются эфирные масла в различных органах, причём могут различаться по составу даже у одного растения. На их накопление влияет целый ряд факторов климатические условия, освещение, возраст и фаза вегетации растений и др.

У некоторых растений имеются т.н. железистые пятна - локализация эфирных масел под кутикулой, причём масло образуется группами выделительных клеток. Такие пятна можно наблюдать на лепестках шиповника (семейство Розовые) или ландыша (семейство Ландышевые), на кроющих чешуях почек тополей корейского или душистого (семейство 
Ивовые). У других видов (семейства Яснотковые, Астровые и др.) имеются железистые волоски, которые состоят из «ножки» и «головки», в которой и накапливается эфирное масло. После повреждения «головки» эфирное масло выделяется во внешнюю среду, и тогда появляется аромат, воспринимаемый человеком.

Эфирные масла могут накапливаться в т.н. вместилищах, или, попросту говоря, полостях. Одни из них образуются в результате выделения секрета между клетками, которые раздвигаются, образуя полость (т.н. схизогенные вместилища). Это наблюдается у растений семейств Сельдереевые, Аралиевые, Клузиевые, Астровые. Есть они и у хвойных растений. Другие возникают как результат разрушения клеток, накопивших секрет. Такие лизигенные вместилища характерны для цитрусовых.

На планете довольно много эфиромасличных растений - не менее двух тысяч видов. И использовать их человек начал давно - считают, что выделять ароматические компоненты из растений человек научился около 5 тысяч лет назад! Представители древних цивилизаций Египта, Шумера, Китая и др. применяли их для благовоний, курений, притираний.

Достаточно эфироносов и во флоре Приморья. Содержание эфирных масел широко варьирует - от долей процента до 18-20\%. Эфирные масла содержатся у растений различных семейств, но в большей мере они присущи представителям семейств Яснотковые, Гвоздиковые, Сельдереевые, Вересковые, часто встречаются у хвойных растений. В то же время, например, у осок, злаков их практически нет.

В плодах лимонника китайского (семейство Лимонниковые) и бархата амурского (семейство Рутовые) эфирные масла накапливаются в особых межклетниках под кутикулой околоплодника; в семенах лимонника между твёрдой оболочкой и эндоспермом находится однорядный слой крупных клеток, продуцирующих эфирное масло. У целого ряда растений семейств Яснотковые, Вересковые, Берёзовые, Ореховые, Ивовые эфирные масла накапливаются в железистых волосках, являющихся производными эпидермы. Эти волоски имеют различную структуру, бывают одноклеточными и многоклеточными. У одних растений волоски имеются только у молодых листьев, а потом отмирают (тополь корейский, тополь душистый, орех маньчжурский). У большинства они имеются и на зрелых листьях, а также на плодах, стеблях.

У бархата амурского эфирных масел особенно много в плодах (до 8\%). Оно обладает антигельминтозным, бактерицидным действием. Если корова отведает листьев бархата, то её молоко не прокиснет несколько дней.

У аира обыкновенного (семейство Аировые), растущего по водоёмам, эфирное масло накапливается в корневищах, точнее, в клетках гиподермы. В его составе многочисленные компоненты, среди которых можно назвать камфен, цинеол, камфора, эвгенол и др. Кстати, сами корневища пахнут довольно приятно, но чистое эфирное масло обладает не слишком приятным ароматом, поэтому его используют (в косметических целях, для отдушки мыла) в сочетании с другими компонентами. Есть такие клетки и в корневищах валерианы (сем. Валериановые).

В корневищах эфирное масло накапливается и у других растений. У родиолы розовой (семейство Толстянковые) оно пахнет как цветки шиповника, за что растение и получило своё название. В состав эфирного масла входят различные компоненты - гераниол, цитраль, коричный альдегид и др. Этот вид, внесённый в Красную книгу Приморского края, произрастает главным образом по высокогорьям, в подгольцовом поясе, и обладает, наряду с женьшенем и свободноягодником колючим (элеутерококком), замечательными адаптогенными свойствами. 


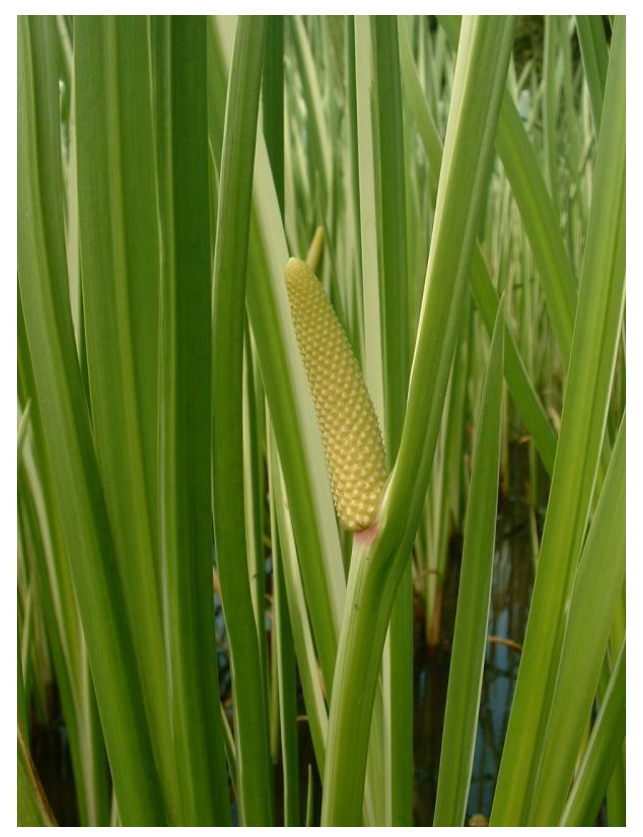

Аир обыкновенный (https://wikipedia.org)

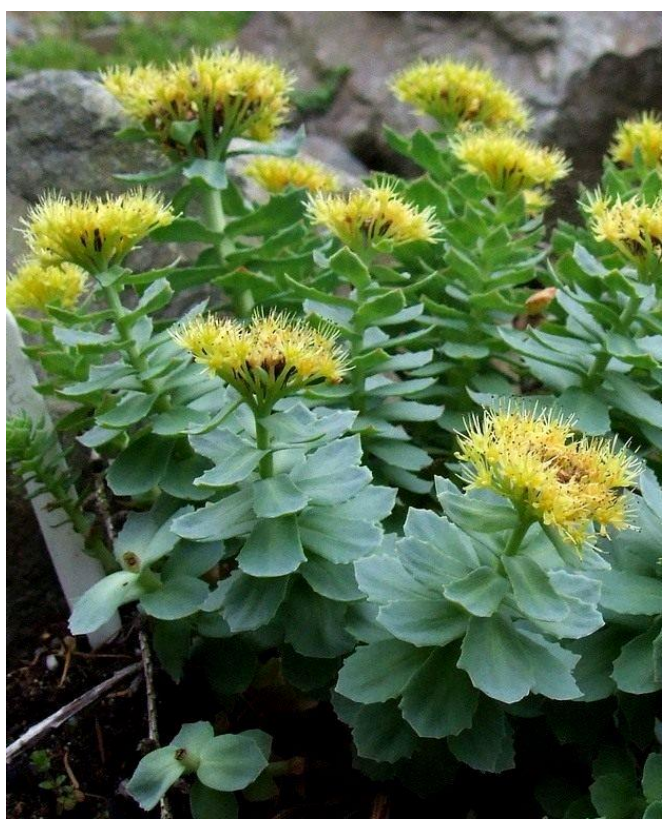

Родиола розовая

(https://pics.botanichka.ru)

Яркий пример эфиромасличных растений - ясенец пушистоплодный, родственник амурского бархата. Оба растения относятся к семейству Рутовые, куда входят и цитрусовые. Но если бархат - высокое дерево, то ясенец травянистый многолетник, достигающий метровой высоты. Его примечательное свойство - высокое содержание в надземных частях эфирных масел, которые постоянно испаряются, создавая вокруг растений целое невидимое облачко. Если в тихие безветренные сумерки подойти к зарослям ясенца и поднести к крайнему растению зажженную спичку, то эфирные пары сразу вспыхнут, и слабое светло-голубое пламя окутывает все заросли, создавая незабываемое зрелище. Однако малейший порыв ветра гасит это пламя. Растения нисколько не страдают от этого пламени, отсюда народное название растения - «неопалимая купина».

Другой пример - багульник болотный из семейства Вересковые. В состав его эфирного масла (да и других видов багульника) входит до 50 различных компонентов с преобладанием ледола, палюстрола, пинена и др. При сборе этого известного лекарственного растения следует соблюдать осторожность - если долго вдыхать его аромат, можно отравиться, появятся головная боль, тошнота, могут даже возникнуть галлюцинации.

Мы уже упоминали, что запах растениям могут придавать эфиры органических кислот. Но, пожалуй, в большей степени за него ответственны эфирные масла. Упомянутые выше растения также являются «пахучими».

Причиной запаха могут быть и другие вещества, поэтому о запахах стоит поговорить более подробно.

Они сопровождают нас всю жизнь. Одни доставляют нам удовольствие, вызывают приятные воспоминания, а некоторые даже толкают на необдуманные поступки... Другие же напротив, отталкивают, вызывают отвращение.

Как определить запах? Человек привык сравнивать его с каким-нибудь животным запахом (мускусный запах, например), пахучим растением (запах горького миндаля) или каким-нибудь веществом (камфарный запах). 
Растения, выделяя различные по своей химической природе вещества, могут издавать самые разные запахи. В одних случаях это выделение представляет собой просто избавление от ненужных продуктов обмена, в других же является приспособлением для эффективного опыления.

В парфюмерии широко используется мускус, который сам по себе пахнет резко, даже неприятно, но добавленный в мизерных количествах в духи - улучшает их запах. Мускусный запах дают ароматические соединения с третично-бутильной группой. Из растений Приморья слабым мускусным запахом обладают виды рода адокса из одноименного семейства, которую сейчас называют русским именем мускусница - именно по этому свойству.

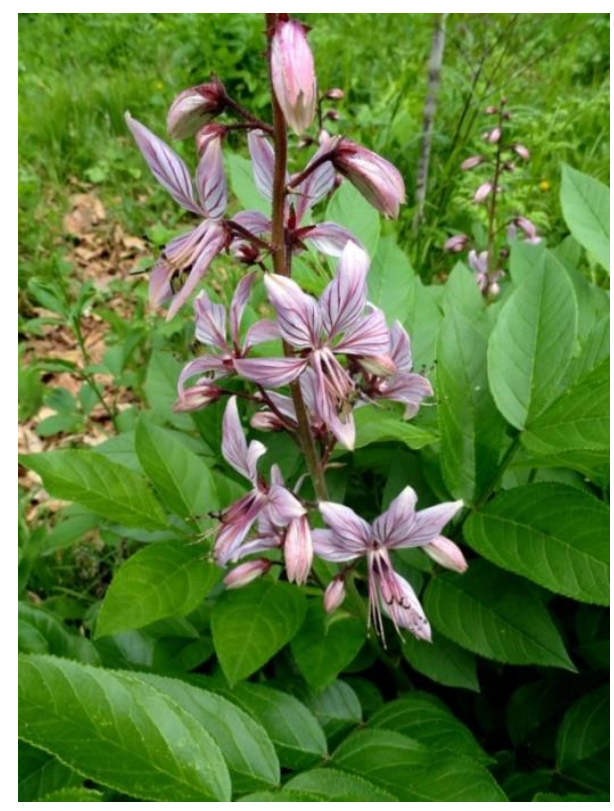

Ясенец пушистоплодный

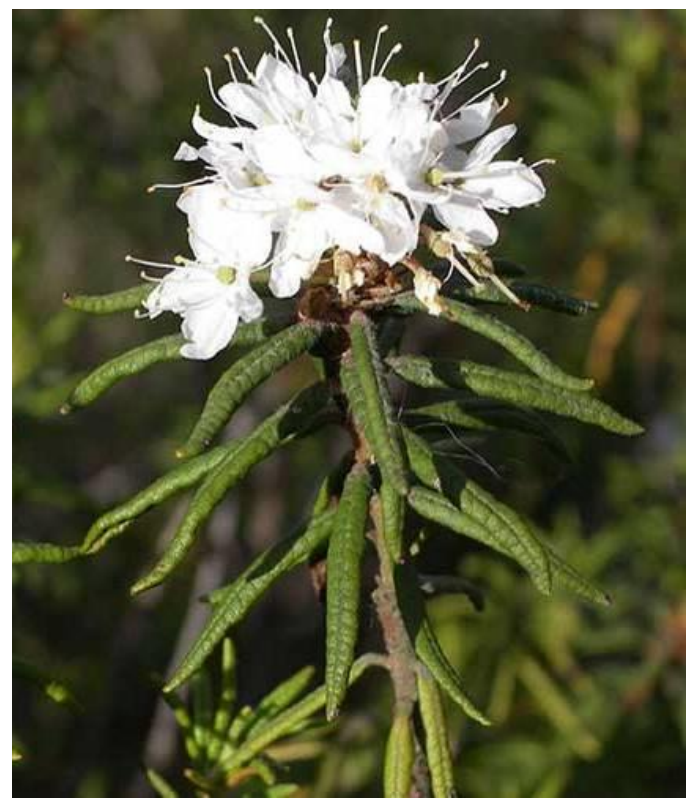

Багульник болотный (https://good-tips.pro)

Камфарный запах обеспечивают гексаметилэтан, метилизобутилкетон, гексахлорэтан и другие вещества. Из растений Приморья можно отметить кирказон маньчжурский (семейство Кирказоновые), древесина которого издает слабый камфарный запах.

Содержащийся в лабазнике вязолистном (семейство Розовые) метилсалицилат придает ему специфический «медицинский» запах.

Приятный запах свежего сена придают растениям кумарины. Этот запах хорошо выражен у некоторых видов зубровки (семейство Мятликовые). Интересно, что растения, содержащие кумарины, в высушенном виде пахнут сильнее, и этот запах держится в гербарии очень долгое время - до нескольких десятков лет!

Весьма своеобразным запахом, который сравнивают с «ароматом» селёдочного рассола, обладают цветки боярышника (семейство Розовые). Его обеспечивает триметиламин $\left(\mathrm{CH}_{3}\right)_{3} \mathrm{~N}$. Любопытно, что у человека встречается мутация, при которой в организме накапливается это вещество (триметиламинурия), и тогда сам человек начинает «отдавать» рыбой.

Характерным запахом обладают луки. Его вызывают серосодержащие тиосульфинаты. Они же присутствуют и у таких капустовых, как ярутка полевая, чесночница. Капустовые вообще отличаются наличием своеобразного запаха, а при гниении выделяют отнюдь не 
ароматный сернистый водород. Иногда человек это использовал - клоповник сорный часто применялся для изгнания этих неприятных насекомых.

Запах ландыша из одноимённого семейства обусловлен наличием спирта линалоола, а запах цветков представителя розовых черёмухи обыкновенной - гликозида пруназина.

Во многих растениях содержатся эфирные масла. У шиповников они представлены т.н. розовым маслом, в состав которого входят такие вещества как цитронеллол, гераниол, нерол, эвгенол и др. В состав эфирного масла лип Приморского края входит спирт фарнезол, обладающий приятным медовым запахом.

Относительно недавно было выяснено, что растения могут не только издавать, но и воспринимать запахи. Оказалось, что повилика растёт в направлении своего хозяина по градиенту запаха, им выделяемого. Вероятно, растения могут «чувствовать» запахи соседних с ними особей при их повреждении, механизм чего пока остаётся загадочным.

К эфирным маслам близки по химическому составу смолы - твёрдые аморфные субстанции содержащие многочисленные индивидуальные нелетучие (а потому непахнущие) соединения. В растениях смолы всегда находятся в связи с эфирными маслами, поэтому и твёрдостью не отличаются. Однако со временем эфирное масло испаряется, и смола твердеет. Тем не менее, какое-то количество эфирного масла как правило остаётся. Смолы достаточно легко окисляются кислородом воздуха, и впоследствии становятся почти невосприимчивыми к действию внешних факторов - янтарь сохраняется десятки миллионов лет!

Много смол содержится в хвойных деревьях, в почках берёзы и некоторых тополей, в корнях ревеня, в стеблях аралии высокой и в других растениях.

Смолы некоторых растений обладают лечебными свойствами, оказывая бактерицидное и антигнилостное действие. В медицинской практике смолы применяют для приготовления пластырей, настоек, иногда используют внутрь как слабительные средства.

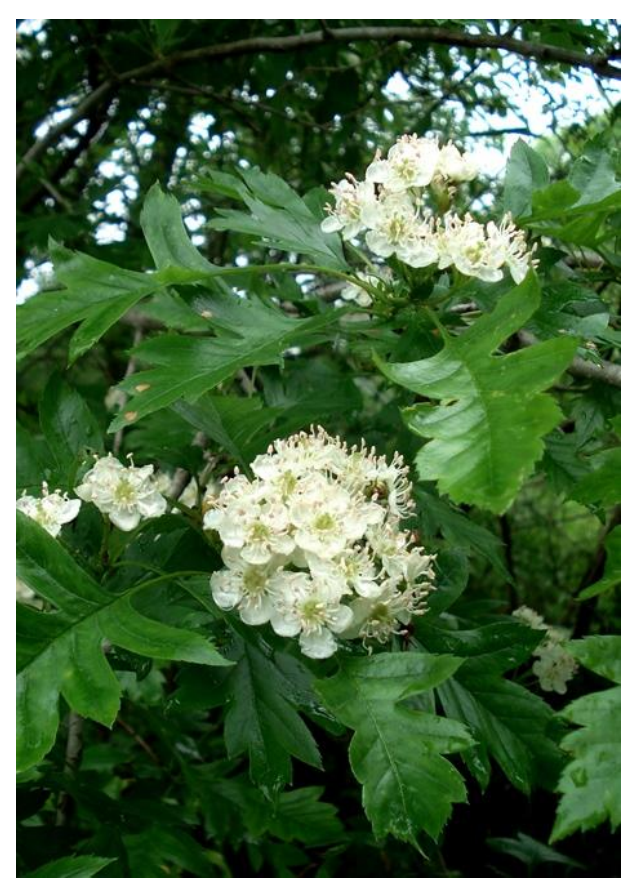

Боярышник перистонадрезанный

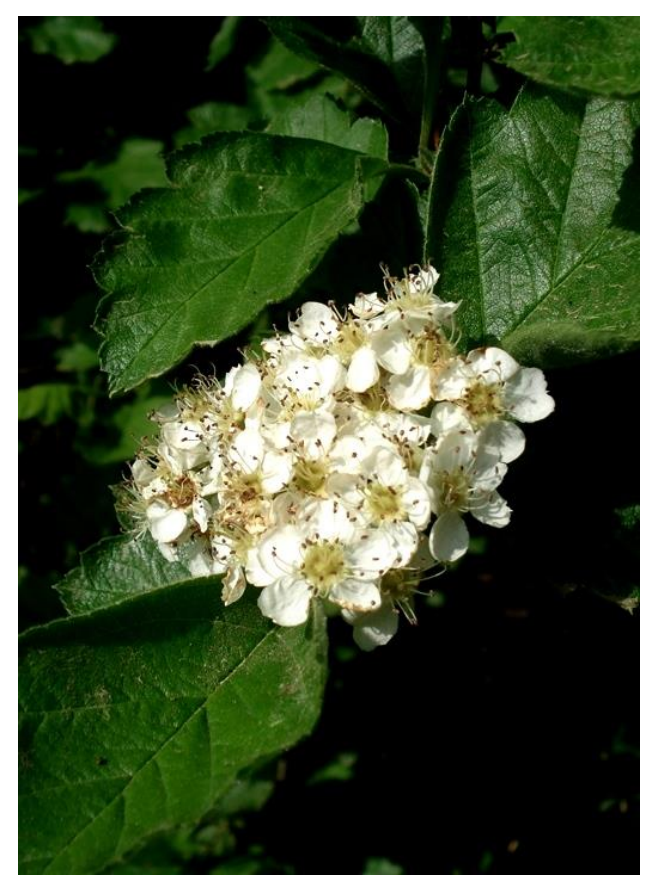

Боярышник Максимовича

Смола одного из хвойных Приморья, пихты белокорой, традиционно используется любителями таежных походов как аварийное ранозаживляющее средство. У этого растения 
смола накапливается во вместилищах в коре. При этом эти вместилища часто хорошо заметны - они бугорками выступают над поверхностью коры ствола, надавил на такой бугорок - и выступила смола. Именно она хорошо помогает при мелких поранениях и порезах, когда другие средства дезинфекции отсутствуют. Стоит смазать ранку смолой - и она одновременно изолирует ее и дезинфицирует.

Подсохшую лиственничную (а также кедровую) смолу в Сибири с давних времен использовали как жвачку - она не только очищает зубы, но и оказывает дезинфицирующее и противоцинготное действие.

Древесина лиственницы, благодаря полимеризации в ней смол, становится очень устойчивой и не поддается ни гниению, ни другой порче. Из лиственницы изготовлены сваи, на которых держатся дома в Венеции, причём за тысячу лет они стали такими твёрдыми, что их не брали ни топор, ни пила.

Много душистой смолы содержат почки приморских тополей (семейство Ивовые) корейского, Максимовича и душистого. За этот приятный аромат отвечают сесквитерпены эвдесмолы, селинены и др.

\section{Минеральные вещества}

Минеральные соединения играют большую роль в жизни растений. Поступают они в растения в виде ионов. Большая их часть входит в состав различных соединений, например, магний является важным компонентом молекулы хлорофилла. Лишь калий находится в растворе в свободной ионной форме.

В целом ряде случаев растения могут накапливать в себе определённые химические элементы. Так, лютиковые избирательно накапливают литий, розоцветные - кобальт и ванадий, паслёновые - хром и никель, осоковые - олово, свинец, титан, бор и алюминий.

Многие растения имеют повышенное содержание кремния. Нужно сказать, что это элемент важен и для организма человека - его суточная потребность составляет около 20 г, а недостаток приводит к различным сердечно-сосудистым заболеваниям. В растительных тканях кремний входит в состав полиуронидов (пектиновой и альгиновой кислот). Довольно много кремния в злаках, осоках, ситниковых, имеется он в папоротниках и особенно - хвощах, в золе последних его содержание доходит до 96\%! Кто зимой бывал в приморских лесах (смешанных, но чаще хвойных), тот наверняка встречал места, где есть заросли хвоща зимующего - на белом снежном фоне хорошо заметны его зелёные стебли. Ещё недавно он был весьма полезным растением для туриста. Это сейчас много портативной туристической посуды и источников огня, а раньше непременным спутником туриста был котелок - в нем варилась еда. Но после трапезы его надо чистить! Задача это нелегкая, однако, если поблизости был хвощ зимующий, проблем не возникало - им как наждаком запросто можно было почистить любой котелок.

Кальций в растениях обнаруживается в ядрах клеток, он входит в состав срединной пластинки, состоящей из протопектина, которая соединяет соседние клетки между собой. Если кальция недостаточно, клетки отходят друг от друга - происходит процесс мацерации. Вот почему при недостатке кальция происходит ослизнение тканей, вызванное распадом клеток. Кальций нейтрализует органические кислоты, переводя их в нерастворимую, безвредную для растений форму. Он поддерживает ионное равновесие почвенного раствора как катион, ослабляющий токсичное действие ионов водорода, алюминия, марганца. Образуемые кальцием соли - яблочная, лимонная, сульфаты - труднорастворимые и медленно передви- 
гающиеся. Кальций накапливается в растениях в старых частях и препятствует их гниению. Поэтому даже при наличии этого элемента они часто испытывают кальциевое голодание запасной кальций им недоступен.

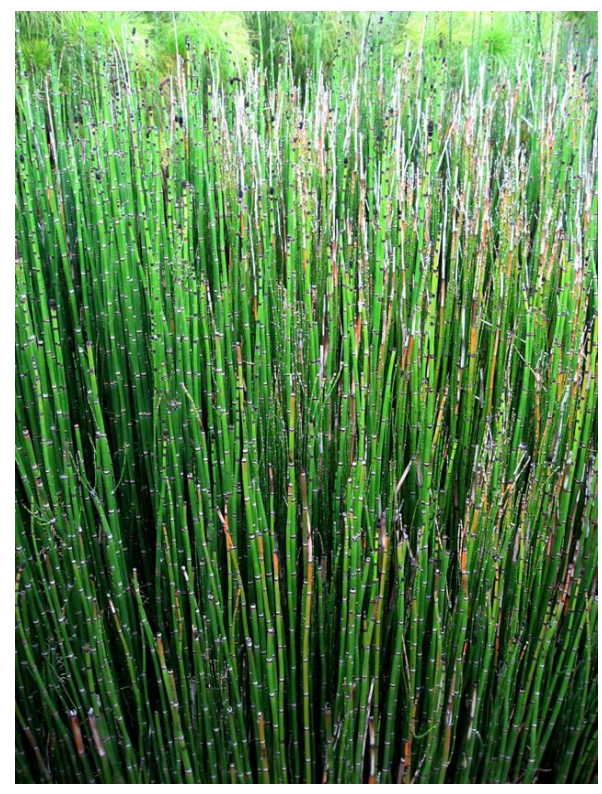

Хвощ зимующий (https://wikipedia.org)

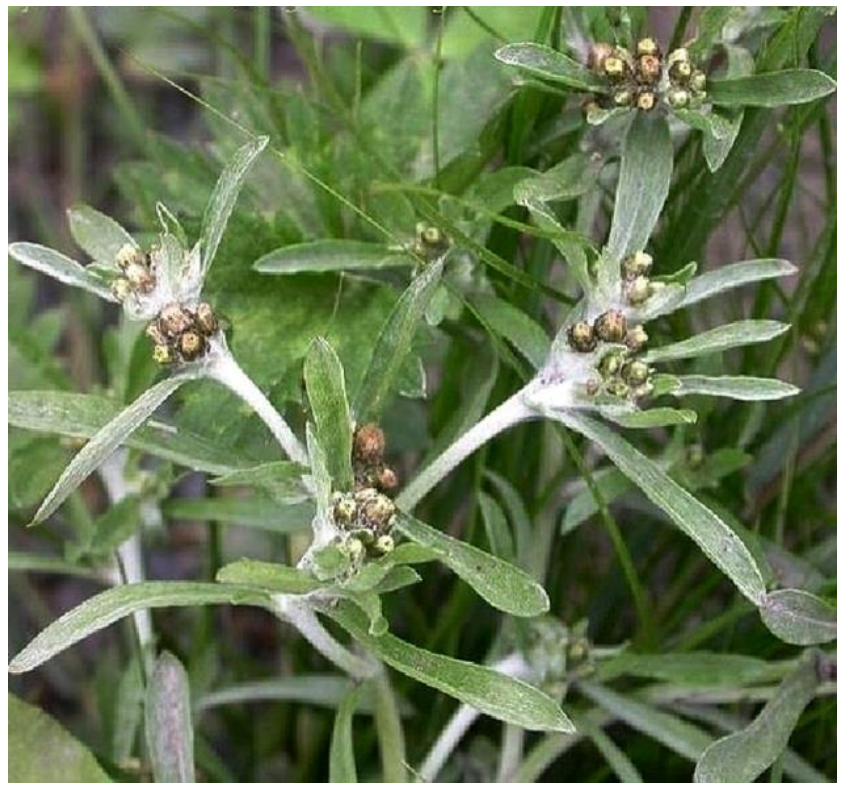

Сушеница топяная (https://tursar.ru)

Мы уже говорили о кристаллах оксалата кальция, встречающихся в клетках растений (друзах и рафидах). К кристаллическим включениям относятся также цистолиты - гроздевидные образования в клетках, образующиеся на выступах клеточной оболочки. Они состоят из карбоната кальция или кремнезема и встречаются у крапивовых, тутовых.

Во многих растениях накапливается цинк, и большинство из них используются в официальной и народной медицине при лечении кожных заболеваний. Это сушеница топяная, череда трёхраздельная (семейство Астровые), якорцы стелющиеся (семейство Парнолистниковые), чистотел азиатский (семейство Маковые).

Железо играет большую роль в физиологии растений, оно входит в состав целого ряда важных ферментов, участвующих в окислительно-восстановительных реакциях - каталаза, пероксидаза, цитохромы. К растениям - накопителям железа относится сушеница топяная из семейства Астровые.

Довольно важную роль в жизнедеятельности растений играет медь, а накапливает её уже упоминавшаяся сушеница топяная.

К накопителям марганца можно отнести багульник болотный (семейство Вересковые) и вахту трёхлистную (семейство Вахтовые).

Кобальт интенсивно накапливают кубышка жёлтая (семейство Кувшинковые), сушеница топяная, черёмухи Маака и обыкновенная, виды шиповника (семейство Розовые).

Накопителем хрома является диоскорея ниппонская из одноимённого семейства. 


\section{Глава 4. Растения в общении}

Все живые организмы на нашей планете находятся в различных взаимоотношениях друг с другом. Эти взаимоотношения могут быть более тесными, когда организмы связаны друг с другом пищевыми связями или общим жилищем, либо менее тесными, например, через другие живые организмы или через неорганическую среду.

Иногда «связующие нити» столь тонки, что их трудно заметить, но нередко они просто бросаются в глаза, а возникающие при этом отношения принимают весьма причудливые формы.

Однако какими бы ни были взаимоотношения, главным критерием при их оценке является конечный результат, который может быть отрицательным, положительным или нейтральным. Что же касается самих взаимодействующих организмов, они могут жить независимо друг от друга, но иногда контактировать (например, хищник и жертва), а могут существовать вместе какой-то период или всю жизнь - это отражает понятие «симбиоз».

Растениям свойственны те же типы взаимодействия, что и для представителей других царств живой природы - и среди них встречаются конкуренты, паразиты, и даже хищники. Если, как мы уже сказали, исходить из результата, у растений встречаются следующие типы отношений: отрицательно-отрицательные (конкуренция), отрицательно-нейтральные (аменсализм), отрицательно-положительные (паразитизм, хищничество), нейтральные (нейтрализм), положительно-нейтральные (комменсализм) и положительно-положительные (мутуализм).

Рассмотрим наиболее яркие проявления связей растений Приморья друг с другом и с другими организмами.

\section{Я тебя съем!}

По типу питания все живые организмы можно разделить на три группы. Представители первой сами создают органические вещества, используя для этого энергию солнечного света либо энергию, выделяемую при окислении различных неорганических веществ. Они называются автотрофами. Первыми солнечное излучение научились использовать бактерии (это произошло около 3 млрд. лет назад), затем эстафету у них перехватили растения. Процесс преобразования солнечной энергии называется фотосинтезом. Если энергию получают, окисляя неорганические вещества (в основном соединения железа, марганца и серы) - это хемосинтез. Хемосинтетиками являются многие бактерии.

Представители другой группы, гетеротрофы, самостоятельно производить органические вещества не могут. С пищей они поглощают уже готовую органику, используя её в различных целях, в том числе для получения энергии. Это большинство бактерий, грибы и животные.

Наконец, существуют умельцы, соединившие оба способа питания. Такие организмы называют миксотрофами - ими являются, например, некоторые жгутиковые простейшие, полупаразиты, насекомоядные растения.

Авто- и гетеротрофы обособились еще на заре жизни на Земле. При этом гетеротрофы, в свою очередь, разделились на три ветви. Одни из них, хищники, начали получать для себя энергию, убивая другие организмы. Другие (паразиты) решили не уничтожать драгоценный источник и начали неспешно «поедать» своих хозяев, которые хотя и страдают от непрошеных нахлебников, но худо-бедно продолжают существовать. Третьи (сапротрофы) 
воспользовались органическими веществами, содержащимися в мертвых остатках растений и животных.

Хищничество - пример отрицательно-положительных отношений в мире живых организмов. Возникло оно еще на начальных стадиях развития земной жизни. Типичные хищники - это, конечно, животные. Изредка в качестве хищников выступают некоторые почвенные грибы, которые залучают в сети своих гифов мелких почвенных животных. Существуют и бактерии-хищники, например, представители открытого в 1962 году рода бделловибрио, а также родов миксококкус, даптобактер.

Растения вовлекаются в отношения «хищник-жертва» двояким образом. С одной стороны, их поедают. Правда, отнюдь не всегда это ведёт к гибели растения, а такие случаи к хищничеству не относятся.

С другой стороны, нередко и растения могут выступать в роли хищников. Однако они не перешли полностью на столь экзотический для них способ питания, а лишь дополнили животной пищей свой рацион, не потеряв способности к фотосинтезу; поэтому их и относят к миксотрофам.

В качестве жертв выступают главным образом насекомые (отсюда название таких растений - насекомоядные), реже - более крупные животные.

На нашей планете насчитывается более 270 видов насекомоядных растений, относящихся к семействам Росянковые, Пузырчатковые, Цефалотовые, Непентовые и Саррацениевые и представленные в основном наземными травами, реже водными растения и полукустарниками. Виды трёх последних семейств обитают в Северной и Южной Америке, Тропической Азии, Австралии, а росянковые и пузырчатковые встречаются и на Дальнем Востоке России.

Зачем же они ловят животных? Дело в том, что насекомоядные растения обитают на бедных, неплодородных почвах или в воде, где питательных веществ тоже недостаточно, поэтому дополнительный азот им совсем не помешает. Ведь он входит в состав белков, выполняющих, как мы уже говорили, многочисленные функции в живых организмах. Вот животные и служат растениям дополнительным источником азотного питания.

Однако насекомых нужно каким-то образом изловить, поэтому растения образовали так называемые ловчие аппараты, которые у различных видов имеют разную форму. Но во всех случаях ими служат видоизменённые листья либо их части.

У тропических растений-хищников семейств Цефалотовые, Непентовые и Саррацениевые они представляют собой разной формы «кувшины». На дне таких ловушек накапливается раствор ферментов, которые выделяются либо бактериями, обитающими в нем, либо желёзками, располагающимися на их стенках. Наиболее крупные ловчие аппараты имеются у непентеса Аттенборо, они могут достигать 50 см длины! В такие крупные ловушки попадают не только насекомые, но и мелкие грызуны и даже птицы.

У венериной мухоловки из семейства Росянковые, произрастающей на атлантическом побережье США, ловчий аппарат двустворчатый. Сев на одну из створок, насекомое задевает чувствительные волоски, и эта своеобразная раковина быстро захлопывается. По краю створок находятся длинные волоски, которые, заходя друг за друга, не дают насекомому выбраться из ловушки. В попытке освободиться оно мечется по ней, задевая новые волоски, что приводит к полному смыканию ловчего аппарата.

Встречающиеся в Приморье насекомоядные растения также принадлежат семействам Росянковые и Пузырчатковые. В каждом семействе имеются как наземные «охотники», так и водные, при этом они применяют различные способы ловли. 


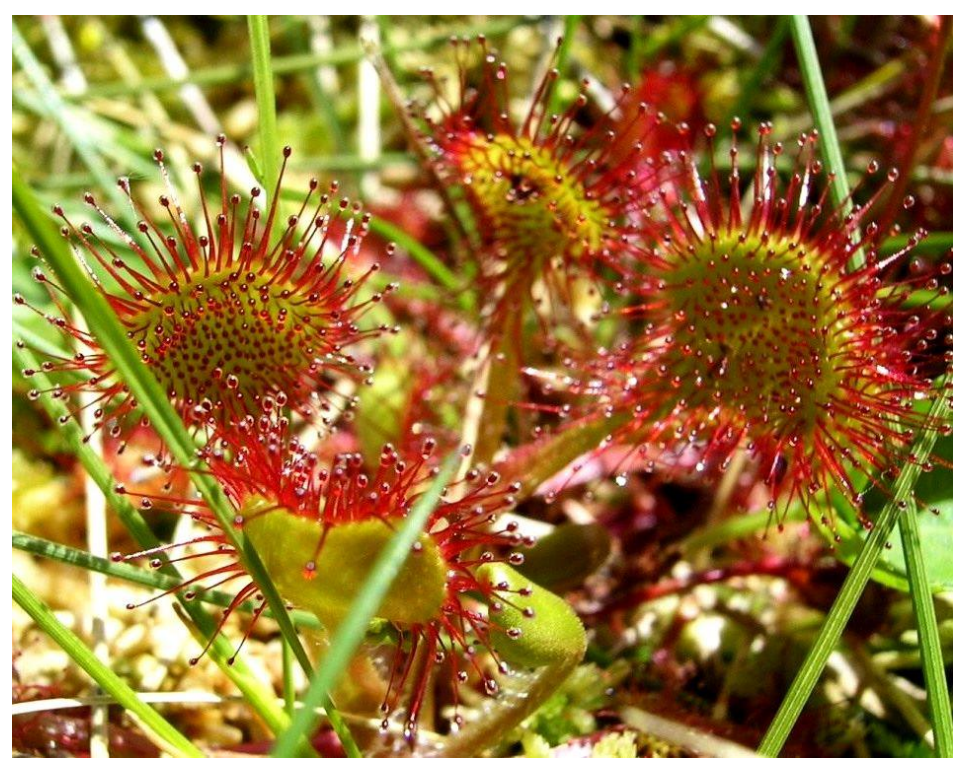

Росянка круглолистная

(https://pics.botanichka.ru)

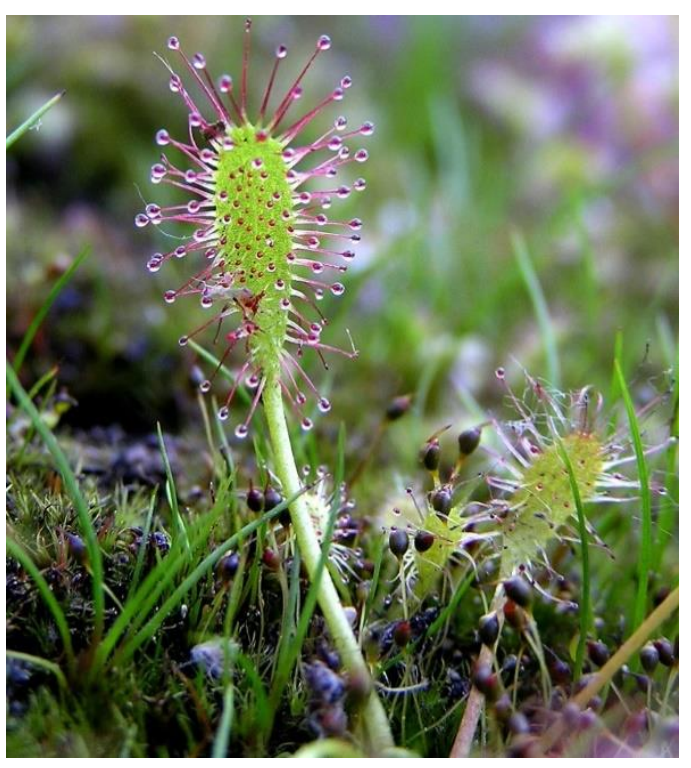

Росянка английская

(https://wikipedia.org)

К наземным насекомоядным растениям относятся представители рода росянка из одноименного семейства. Росянки (у нас два близких вида - круглолистная и английская) растут в основном на болотах, преимущественно сфагновых, встречаются и по песчаным берегам рек и ручьев. Это небольшие растения с розеткой мелких листьев на довольно длинных черешках. Листья покрыты многочисленными длинными (до полусантиметра) железистыми волосками. Одни из них выделяют клейкое вещество (а вместе с ним - алкалоид кониин, оказывающий парализующее действие), другие - пищеварительный фермент, сходный с пепсином животных. Насекомое, привлечённое сверкающей на солнце, как капля росы (отсюда и название растения), головкой железистого волоска, садится на лист, но взлететь не может, поскольку приклеивается, да еще и парализовано.... Лист начинает сворачиваться, полностью окружая бедное насекомое. Затем выделяется пищеварительный фермент, продукты распада поглощаются растением, а непереваренные хитиновые остатки после разворачивания листа уносятся ветром.

Много у росянки хитростей - высокая чувствительность (в этом удостоверился еще Чарлз Дарвин, проводивший свои опыты в 1860 году), реагирование только на живую ткань, выделение веществ, предотвращающих развитие бактерий, временный перерыв в выделении клейкой жидкости после переваривания, чтобы остатки не «приклеились» к листу.

Водных насекомоядных растений в Приморье больше - один вид в семействе Росянковые (альдрованда пузырчатая) и целых пять - в семействе Пузырчатковые (виды пузырчатки - южная, средняя, светло-жёлтая, крупнокорневая и малая).

Альдрованда пузырчатая входит в состав монотипного (включающего один вид) рода альдрованда, описанного в 18 веке Карлом Линнеем. Ареал альдрованды весьма обширный - он включает Евразию, Австралию и Африку. Этот обитатель пресных водоёмов не имеет корней, а, следовательно, не прикреплён к дну и свободно плавает в толще воды близ поверхности.

Ловчий аппарат альдрованды состоит из двух половинок, на которые разделена листовая пластинка. При раздражении чувствительных волосков происходит смыкание половинок аппарата, в результате чего добыча (мелкие беспозвоночные и даже мальки рыб) оказывается пойманной. 


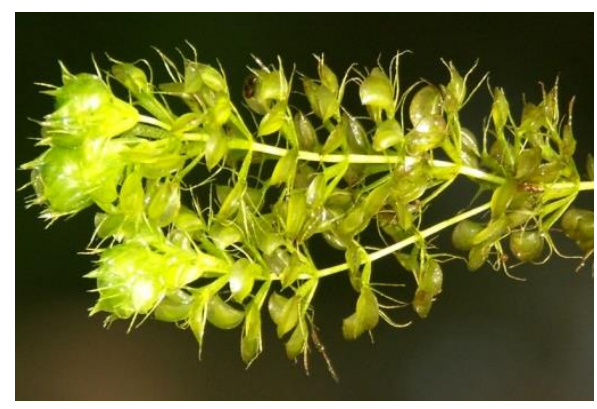

Альдрованда пузырчатая (https://www.plantarium.ru)
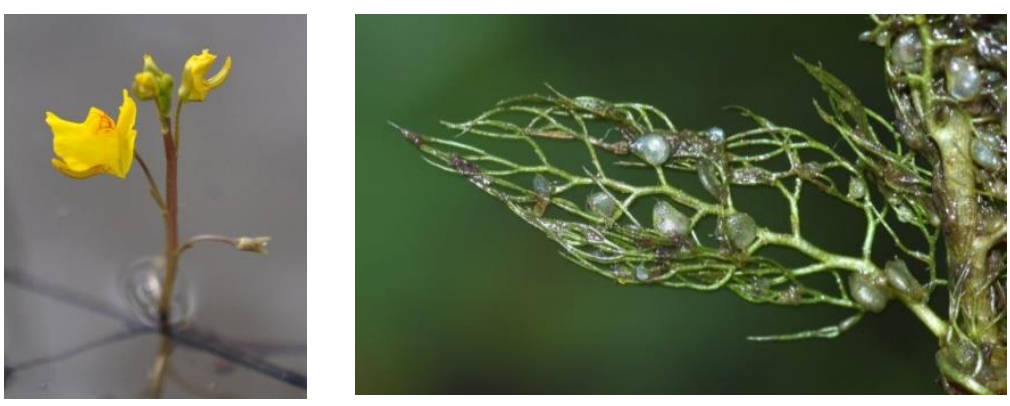

Пузырчатка крупнокорневая и её ловчие аппараты (https://www.plantarium.ru)

Пузырчатки - тоже пресноводные растения, обитающие в озерах, прудах, болотах и даже канавах. У пузырчаток ловчие пузырьки имеют другое, нежели у альдрованды, строение и механизм действия. Особые желёзки выкачивают из пузырьков воду. В результате в нем создается низкое давление (как у резиновой груши, если ее сжать и закрыть отверстие). Пузырек сообщается с внешней средой особым клапаном - «дверцей», который может открываться лишь вовнутрь. На клапане есть чувствительные волоски, которые добыча (различные мелкие беспозвоночные) при приближении задевает. А приближается оно, обманутое тем, что сам пузырек имеет некоторое внешнее сходство с мелким ракообразным - дафнией. Клапан быстро открывается вовнутрь и добыча вместе с потоком воды попадает в ловчий пузырек. Клапан вновь закрывается, добыча оказывается в ловушке. Скорость открытия дверцы впечатляет - меньше миллисекунды! Это одно из самых быстрых движений в мире растений.

\section{Вот паразиты!}

Паразитизм, наряду с хищничеством, - еще один пример отрицательноположительных взаимоотношений между организмами. В данном случае всё положительное приходится на паразита, который получает питательные вещества и жилище от хотя и живого, но в различной степени страдающего от такого малоприятного соседства хозяина.

Точное число видов паразитических растений до настоящего времени не известно, однако даже по примерным оценкам их немало. Считают, что в мире насчитывается около 30000 видов паразитических цветковых растений (а это около десятой части от всех видов растений нашей планеты!) и даже один вид голосеменных растений из рода паразитаксус из семейства Подокарповые - паразитаксус опалённый, растущий в Новой Каледонии.

Отношения «паразит-хозяин» в мире растений весьма разнообразны. Так, большинство растений-паразитов обитает на теле хозяина, «присасываясь» к нему своими корнями. Но в редких случаях встречаются и удивительные эндопаразиты, обитающие внутри тела своего хозяина. Как ни странно, это виды раффлезии, о которой шла речь в первой главе. Оказывается, тело раффлезии имеет вид нитей, которые погружены в ткани хозяина - обычно лиан из рода циссус (семейство Виноградовые). Лишь цветки находятся снаружи - на стволе лианы, если они небольшие, либо на земле, если огромные, как у раффлезии Арнольда.

Различаются паразиты и степенью «эксплуатации» хозяина. Одни, имея листья, могут фотосинтезировать, создавая органические вещества и получая от хозяина лишь воду с ми- 
неральными веществами. Это так называемые полупаразиты. Другие же берут от хозяина всё, теряя при этом способность к фотосинтезу.

Бывает так, что паразиты имеют своих паразитов. Это явление называют суперпаразитизмом. Среди растений суперпаразитизм редок. Например, в Америке некоторые виды омелы паразитируют на других видах омелы, а те - уже на своих хозяевах.

Еще одно отличие заключается в природе органов, с помощью которых паразиты поглощают из хозяина питательные вещества. По этому критерию все растительные паразиты разделяются на две группы.

Представители первой развивают всасывающие структуры (гаустории), которые погружаются в ткани хозяина и извлекают из него питательные вещества. По своему происхождению гаустории являются видоизменёнными корнями.

Наиболее известны растения, стебли которых обвивают стебли своих хозяев и в местах соприкосновения образуют придаточные корни, проникающие в ткани хозяина. Это представители семейства Повиликовые.

В Приморье произрастают семь видов повилики, наиболее распространённым из которых является повилика японская. Ботаником она легко узнается по сросшимся столбикам и овальной коробочке, другой яркий признак - шнуровидные пурпурные стебли, обвивающие стебли как дикорастущих, так и, реже, культурных растений. Спектр хозяев этого растения весьма широк и включает травянистые и древесные виды - полынь и черёмуха, ива и метаплексис, леспедеца и репяшок и многие другие. У повилик нет листьев, они являются облигатными (обязательными) паразитами.

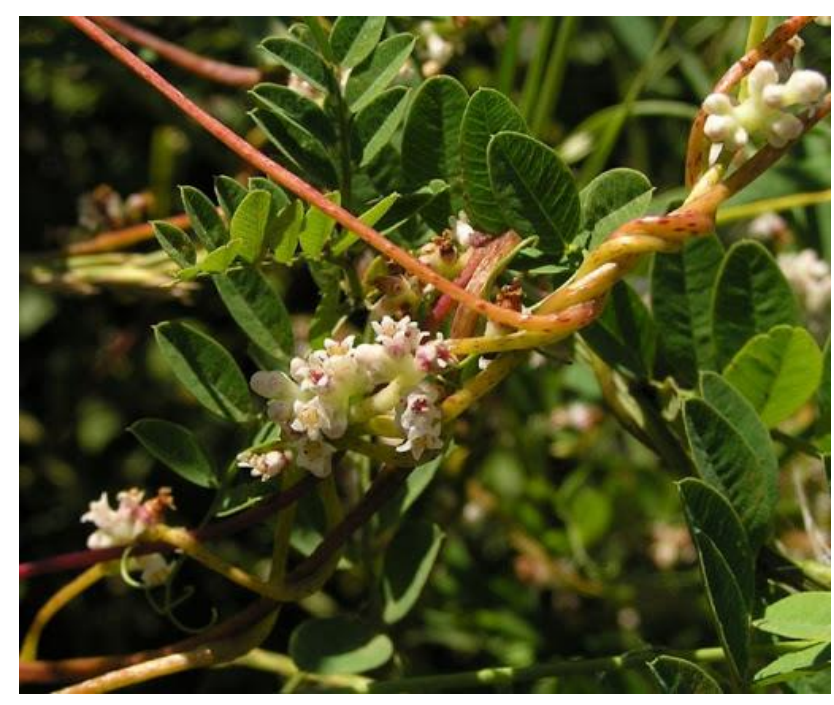

Повилика японская (http://molbiol.ru)

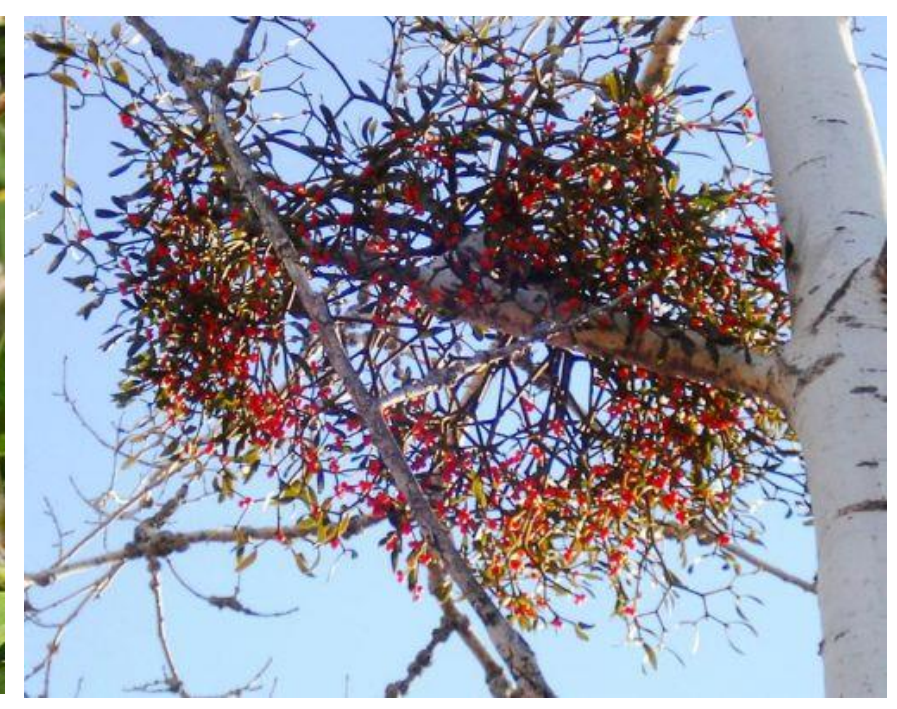

Омела окрашенная (https://colourmaster.ru)

У видов семейства Омеловые в ткани хозяина проникают видоизменённые главные корни. В Приморье представителем этого семейства является омела окрашенная.

Проезжая зимой по крупным автотрассам, невольно замечаешь на ветвях деревьев какие-то «шары». Это и есть омела окрашенная -эпифитный полупаразитический кустарник, формирующий шаровидную крону до 1,3 м в диаметре. Любопытно, что эта шаровидность достигается несколькими путями. Ветви омелы ветвятся ложнодихотомически, т.е. каждый побег даёт на верхушке вилку из двух молодых побегов, и все это происходит в одной плоскости. При этом отдельные ветви растут под разными углами. Кроме того, нередко образует- 
ся не два, а три и более молодых побегов, да и длина ветвей, несмотря на различия в длине отдельных междоузлий, примерно одинакова - все это и ведёт к возникновению шаровидности кроны.

Омела поселяется на видах семейств Ивовые, Берёзовые, Липовые, Клёновые, Розовые, особенно в долинах рек и в окрестностях населённых пунктов, в горный пояс не заходит. На растении она встречается на высоте от двух метров (на молодых деревьях) до 2225 метров.

Плод омелы - красно-оранжевая или жёлтая ложная ягода до одного сантиметра в диаметре. В околоплоднике содержится очень клейкое вещество - висцин, который способствует прикреплению семян (с помощью птиц, о чем будет рассказано далее) к ветвям древесных растений. Спустя некоторое время после прорастания семени образуется гаустория, внедряющаяся в ткани хозяина. Впоследствии от неё отходят так называемые коровые корни, цилиндрические или овальные, распространяющиеся вдоль ветви хозяина. На продольном срезе ветви растения-хозяина они заметны как относительно тонкие тяжи, проходящие между корой и древесиной (они заметны благодаря более светлой окраске). В различных местах ветви растения-хозяина могут возникать новые побеги омелы. На поперечном срезе ветви растения-хозяина их гаустории заметны в виде светлых овалов. Гаустории старых растений омелы могут занимать почти весь объём поперечного среза ветви растения-хозяина.

Наконец, у некоторых растений гаустории, образующиеся на корнях, внедряются в корни растений-хозяев. В эту группу входят растения девяти семейств, из которых на территории Приморья встречаются растения семейств Норичниковые и Заразиховые.

Представители заразиховых в Приморье - это бесхлорофилльные травянистые растения из трёх родов - заразиха (три вида), бошнякия (один вид - бошнякия русская) и пучкоцвет (один вид - пучкоцвет трубкоцветковый). У них наблюдается строгая «специализация»: заразихи паразитируют на полыни, бошнякия - на ольховнике или ольхе, а пучкоцвет - на ясене.

Как происходит заражение, можно рассмотреть на примере заразих. Её очень мелкие семена с осадками проникают в почву. Если при этом семя оказалось поблизости от корня растения-хозяина (как правило, на расстоянии не более 0,5 см), то вещества, выделяемые корнями хозяина, вызывают прорастание семени и рост зародышевого корешка по направлению к корню хозяина. После контакта верхушка корня заразихи превращается в гаусторию, внедряется в корень хозяина и достигает проводящих тканей.

Полупаразиты из семейства Норичниковые в Приморье представлены кастиллеей бледной, зубчаткой обыкновенной, а также видами очанки, погремка и марьянника. Это с виду обычные травы, до 40(60) см высоты, в основном однолетние (марьянник розовый, погремки, зубчатка обыкновенная, очанки Максимовича и уссурийская), произрастающие главным образом по открытым участкам - лугам, обочинам дорог и др.

Растения второй группы не имеют гаусторий - они образуют специализированные ткани (которые получили название гаусториальных), принимающие гифы гриба. Такие растения называются микотрофными (питающиеся с помощью грибов). Они традиционно относятся к так называемым сапрофитным растениям. 


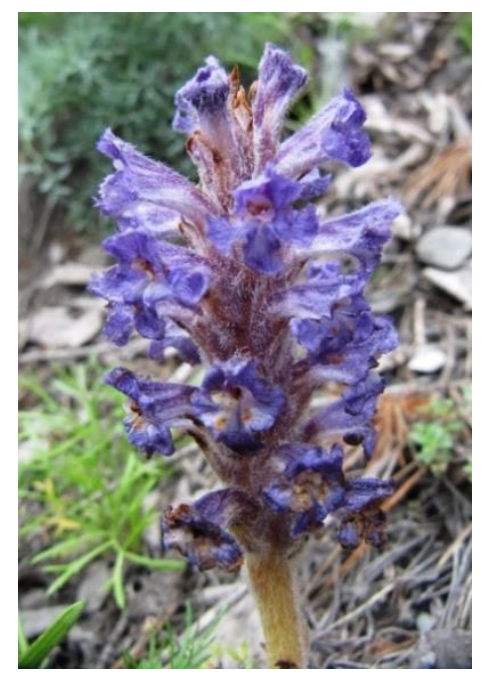

Заразиха синеватая

(https://www.plantarium.ru)

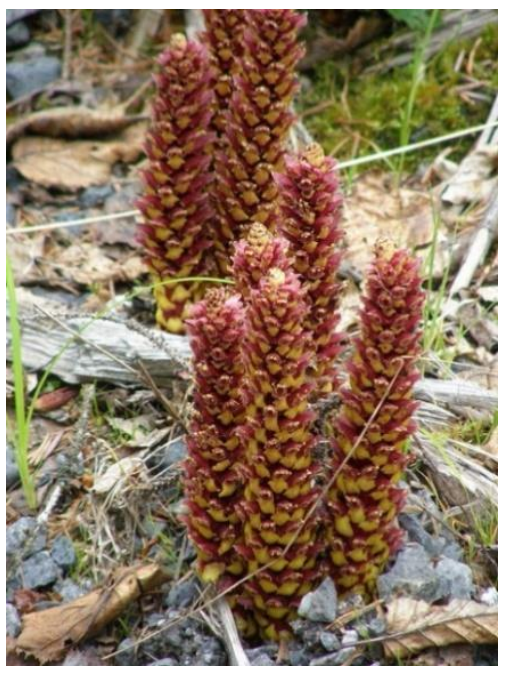

Бошнякия русская

(https://www.lekrs.ru)

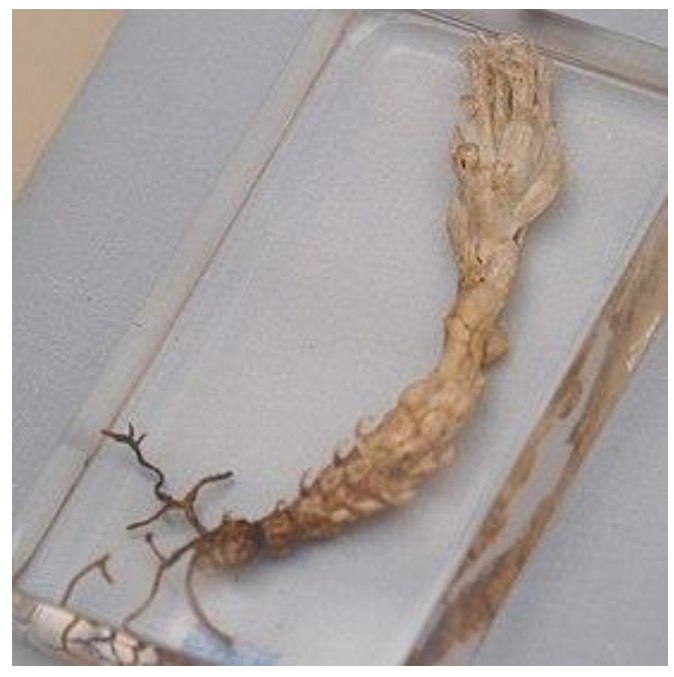

Пучкоцвет трубкоцветковый (https://www.wikipedia.org)

Выделяют две формы микотрофных растений.

Представители семейства Грушанковые (а также семейств Горечавковые, Истодовые и ряда других) характеризуются тем, что питание осуществляется в результате проникновения гиф микоризного гриба в клетки основания проростка. Интересно, что зародыши в этом случае начинают прорастать в отсутствии гриба, но затем приостанавливают своё развитие, «выжидая» контакт с грибом. Время такого ожидания может быть весьма продолжительным до целого вегетационного периода. Если же за это время заражения гифами гриба не произошло, проросток погибает.

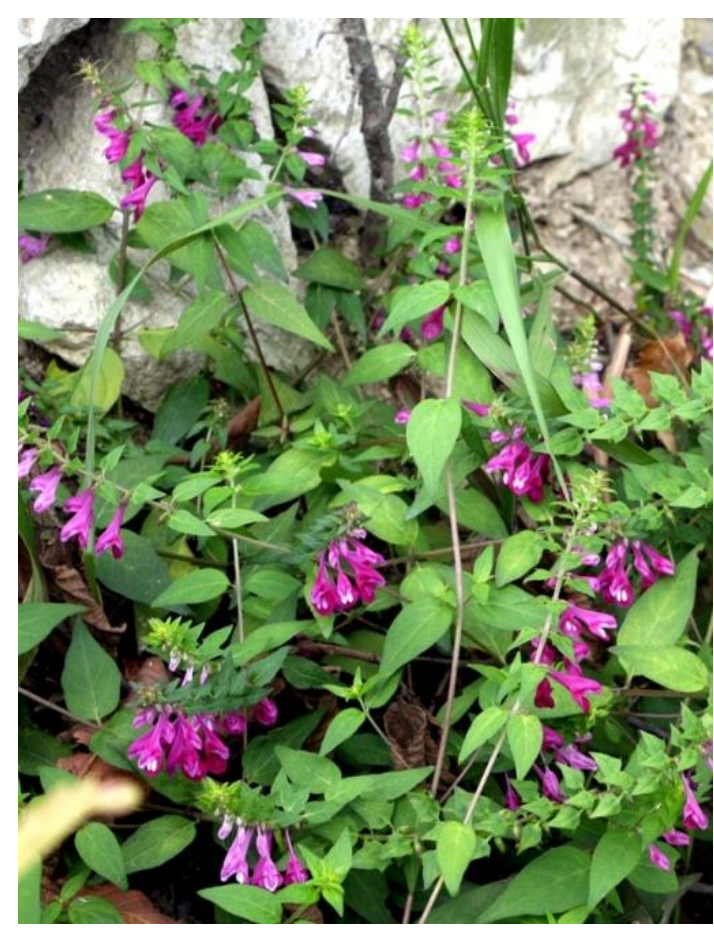

Марьянник розовый (https://www.wikipedia.org)

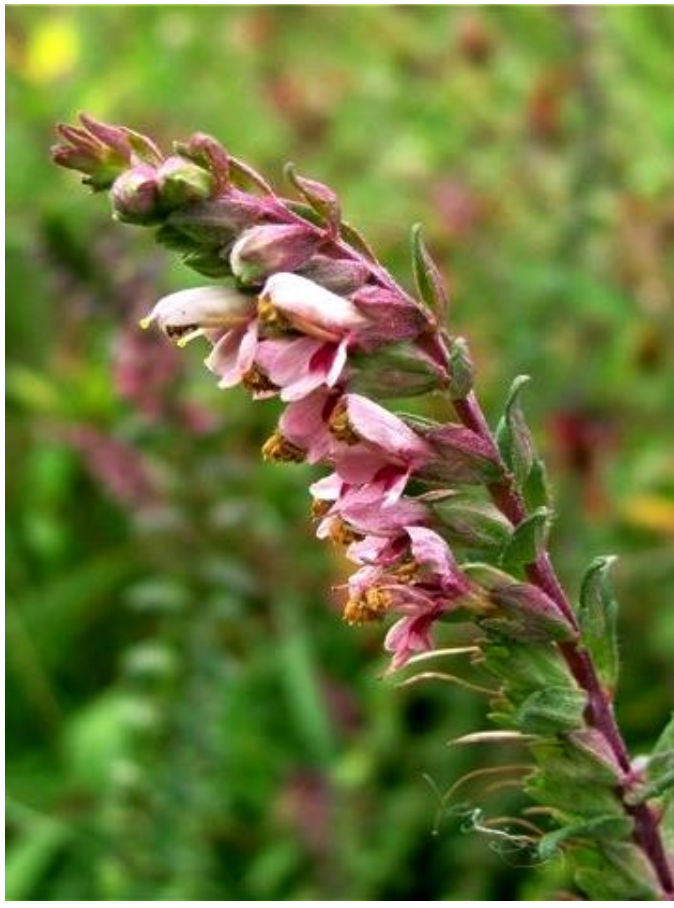

Зубчатка обыкновенная (https://lektrava.ru) 
А вот растения семейства Орхидные ещё более строги - их семена прорастают только после того, как гифы гриба внедрятся в ткани зародыша. Из-за этого орхидеи в Европе долгое время не могли размножить семенами, вследствие чего приходилось снаряжать многочисленные экспедиции за этими фантастическими растениями, от которых европейцы 19 века просто сходили с ума.

Только в 1899 году француз Ноэль Бернар обратил внимание, что семена одной из орхидей, гнездовки, проросли прямо в подземных плодах. Он предположил, что в прорастании семян важную роль играют грибы. Это предположение впоследствии подтвердилось и было доказано в эксперименте.

В Приморье произрастают около 35 видов семейства Орхидные (Ятрышниковые) из 22 родов, причём многие роды (понерорхис, пололепестник, горноятрышник и др.) представлены лишь одним видом.

Наиболее впечатляющи, конечно, венерины башмачки, которых в Приморье насчитывается три вида - настоящий, крупноцветковый и пятнистый. Это травянистые корневищные многолетники до 50 см высоты, растущие в лесах - как лиственных, так смешанных и хвойных. Один из лепестков этих растений превращён в т.н. губу, которая напоминает по форме деревянный башмак голландских крестьян, что и послужило причиной названия растений. У венерина башмачка настоящего губа жёлтая, у крупноцветкового - розовая, у пятнистого беловато-розовая с тёмно-пурпуровыми пятнами.

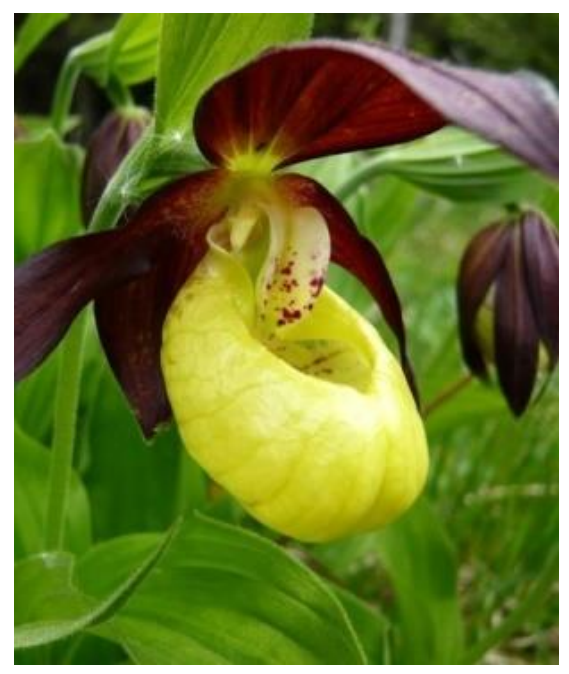

Венерин башмачок

настоящий

(https://flowertimes.ru)

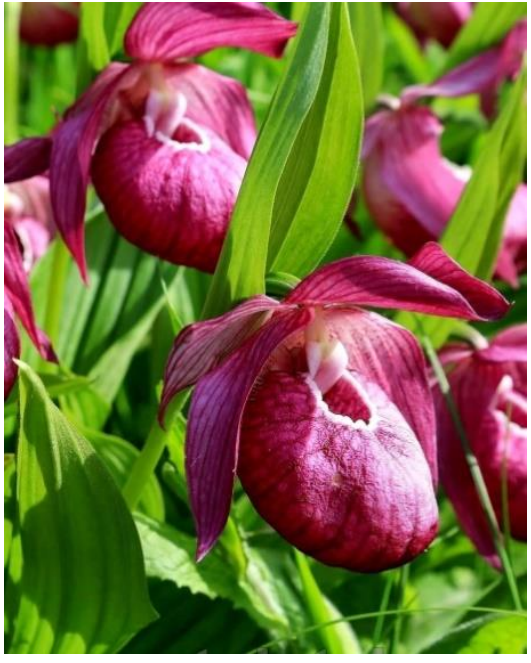

Венерин башмачок

крупноцветковый

(https://www.altzapovednik.ru)

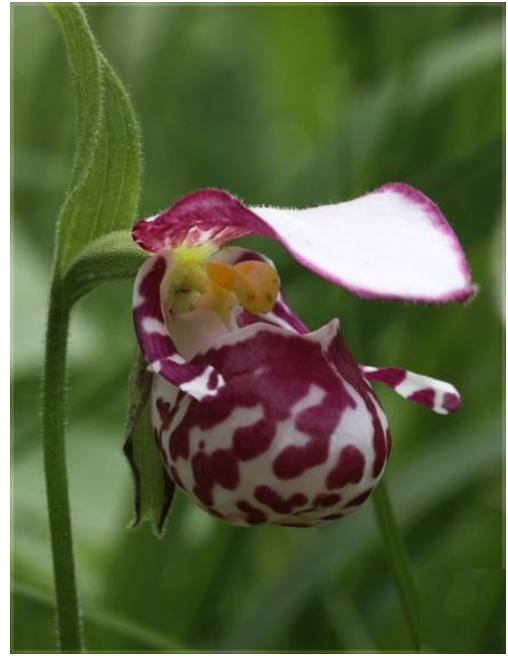

Венерин башмачок пятнистый (https://media2.24aul.ru)

Что касается самих отношений гриба и растения, предпочитают говорить, что они находятся в состоянии взаимного паразитизма. Именно о взаимном паразитизме (при установившемся лабильном равновесии растения и гриба), а не о мутуализме, свидетельствуют наблюдения в природе: во многих случаях гриб, атакующий, например, семя орхидеи, вместо нормального и специфичного для него роста пронизывает все клетки зародыша, и тот погибает; имеют место и обратные случаи, когда защитные силы зародыша столь велики, что гифы гриба не могут проникнуть в его ткани, что также приводит к гибели зародыша.

Пути, с помощью которых растение получает питательные вещества от гриба, многообразны. На начальных стадиях эволюции таких отношений происходит поглощение раство- 
ра минеральных веществ из грибных гифов, на поздних происходит более или менее полное переваривание грибных гиф в клетках высшего растения.

\section{Какой мне прок от наших отношений?}

Бывает так, что один из взаимодействующих видов извлекает пользу, другой же не получает ничего. Такой тип взаимоотношений назвали комменсализмом, от латинского «сотрапезничество», по наиболее явному примеру подобного явления. В природе существуют многочисленные примеры таких связей у животных (со школы помнятся отношения львов и гиен, акул и рыб-прилипал), но есть комменсалы и среди растений, в том числе Приморья.

Одним из примеров комменсализма является эпифитизм. Это явление, когда одни растения находят себе место для проживания на других растениях, причём при этом они не паразитируют на них. Эпифитизм наиболее характерен для тропиков с их постоянной высокой температурой и влажностью. Эпифитами являются мхи, лишайники, водоросли, папоротники, из цветковых растений - представители семейств Бромелиевые, Орхидные, Геснериевые и др.

В Приморье цветковые растения-эпифиты отсутствуют (уже упоминавшаяся омела хотя и растёт на деревьях, но является полупаразитом). В некоторых случаях в основании ствола, между выступами корней и в складках коры может накапливаться субстрат, и если в него попадёт семя, оно может прорасти. Создается впечатление, что появившееся растение растёт на стволе. Однако это типичный обман, такое явление называют псевдоэпифитизмом. В то же время на стволах деревьев Приморья часто встречаются другие эпифиты - лишайники и водоросли.

Еще одни сторонники комменсализма - лианы. Их стебли не могут расти вертикально и поэтому нуждаются в опоре для пробивания к свету. Лианы - очень древние растения. Их далекие сородичи произрастали еще в лесах каменноугольного периода. Сегодня больше всего лиан, почти 2000 видов (а это 90\% всех лиан мира) произрастает в тропиках. В умеренном поясе, где располагается и Приморский край, их гораздо меньше, примерно 200 видов. Немало лиан - травянистых и древесных - во флоре Приморья.

Все лианы различаются способом прикрепления к опоре. Одни из них цепляющиеся, другие вьющиеся.

Цепляющиеся лианы принадлежат семействам Виноградовые, Тыквовые, Сассапарилевые и др. Среди них преобладают усиконосные лианы.

У представителей семейств Виноградовые и Тыквовые усики имеют побеговое происхождение.

У виноградовых наиболее мощными усиками обладает виноград амурский, широко распространённый в наших лесах и нередко культивируемый. Они достигают тридцати сантиметров длины, как правило зелёные (но на свету приобретают красноватую окраску из-за накопления антоцианов), голые или опушённые длинными белыми закручивающимися волосками. Обычно усик разветвляется на две оси, из которых морфологически нижняя ось всегда длиннее верхней. Он обвивает опору как по направлению движения часовой стрелки, так и против. Более того, одна часть усика может обвивать опору по часовой стрелке, другая часть того же усика - против него. С течением времени направление обвивания может меняться. Нижняя свободная часть усика нередко сворачивается в спираль, что обеспечивает эластичное соединение с опорой. Оно обеспечивает необходимые изгибы и повороты стебля 
при росте и предотвращает его механические повреждения, а усики - от разрыва. О побеговом происхождении усика свидетельствует его анатомическое строение.

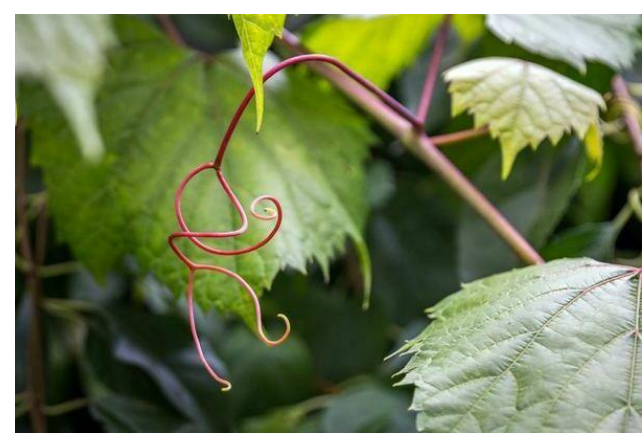

Усик винограда амурского (https://ogorodnash.ru)

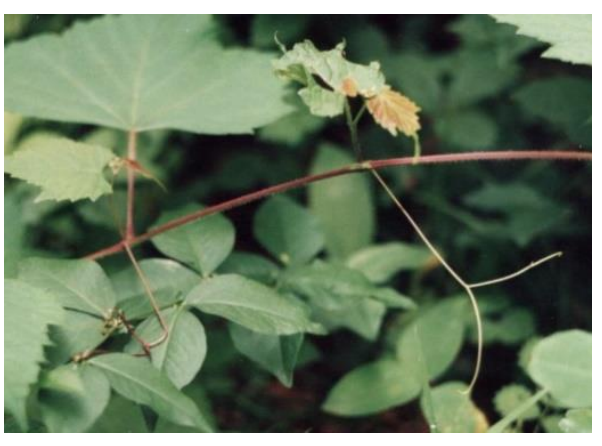

Усики виноградовника короткоцветоножкового

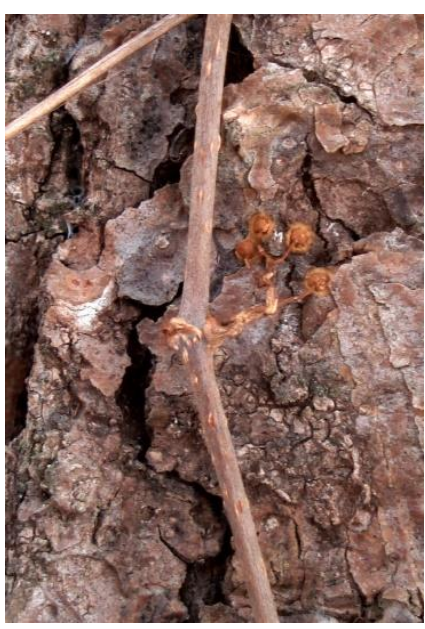

Усик девичьего винограда триотрённого

У виноградовников усики являются видоизменёнными соцветиями (генеративными побегами). У нас произрастают три вида - виноградовник короткоцветоножковый (усики относительно короткие, до 10 см длины), виноградовник разнолистный (усики до 7-10 см длины и 0,1 см в диаметре, зелёные или красноватые (на свету), виноградовник японский (усики 10-12 см длины, тонкие, до 0,9 см в диаметре, голые).

Самые мелкие усики у девичьего винограда триострённого - 3-4 см длины, разветвлённые. На их концах имеются дисковидные расширения, выделяющие клейкое вещество, с помощью которого и происходит прикрепление к опоре. Таким образом эта лиана способна намертво прикрепляться даже к совершенно гладкой поверхности. Это очень помогает девичьему винограду в природе - ведь он встречается по вертикальным гранитным скалам морского побережья на юге Приморья.

Представители тыквовых имеют усики, также являющиеся видоизменением побега. Это тладианта сомнительная, схизопепон бриониелистный, актиностемма лопастная и эхиноцистис лопастный, или «стреляющий плющ». Последнее растение, родом из Северной Америки, было занесено в Европу и затем широко распространилось в Евразии. Его тонкие слабые побеги поддерживаются на опоре с помощью крепких ветвящихся 3-4-раздельных усиков, закрученных в крутую сильную спираль, похожую на часовую пружину. В Приморье в местах посадок эхиноцистис нередко создает сплошные заросли.

Есть случаи, когда усики являются видоизменёнными листьями (точнее, видоизменениями их частей) - это свойственно бобовым и сассапарилевым.

У многих бобовых в усик видоизменяются части сложного листа или, реже, весь лист. На примере гороха оказалось, что если размер меристематического бугорка превышает некий верхний предел, то он превращается в участок рахиса, если нет - образуется усик; при промежуточных значениях образуется листочек. Усики бобовых, обвивая как опору, так и собственные соседние стебли и листья, создают довольно прочную рыхлую, но упругую структуру, которая максимально отвечает требованиям фотосинтеза и аэрации. Из бобовых Приморья, имеющих усики, можно назвать растения родов горошек и чина. 
Наконец, у единственного представителя семейства Сассапарилевые, произрастающего в Приморском крае - сассапарили Максимовича, усики являются видоизменениями прилистников. Они располагаются в основании черешков, супротивные, 8-9 см длины и около 0,8 мм в диаметре, чаще всего закручиваются около этого же или соседнего узла. Встретить этот небольшой, до трёх метров высоты, лазающий кустарник можно в долинных лесах, в зарослях кустарников.

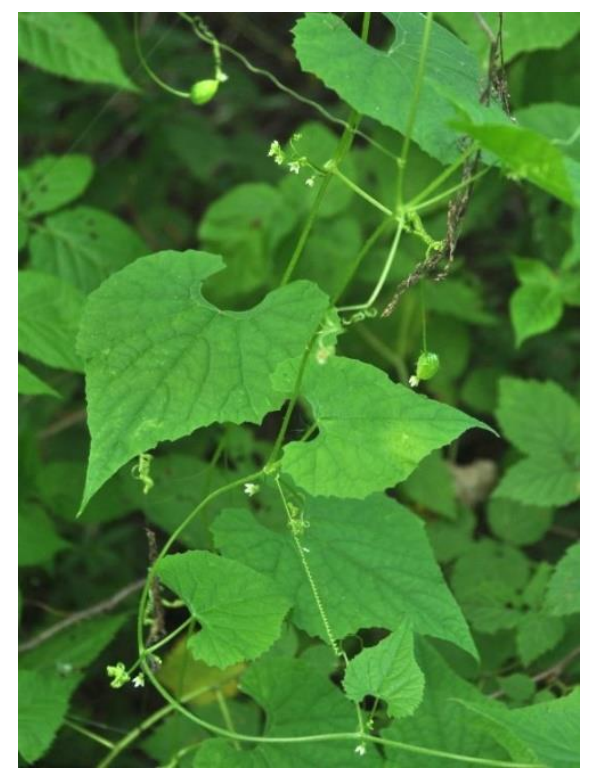

Схизопепон бриониелистный (https://www.plantarium.ru)

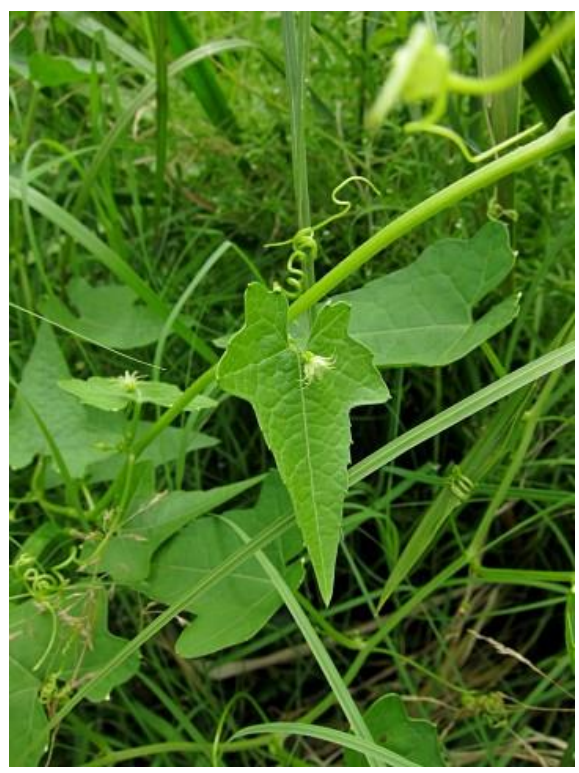

Актиностемма лопастная (https://m.ok.ru)

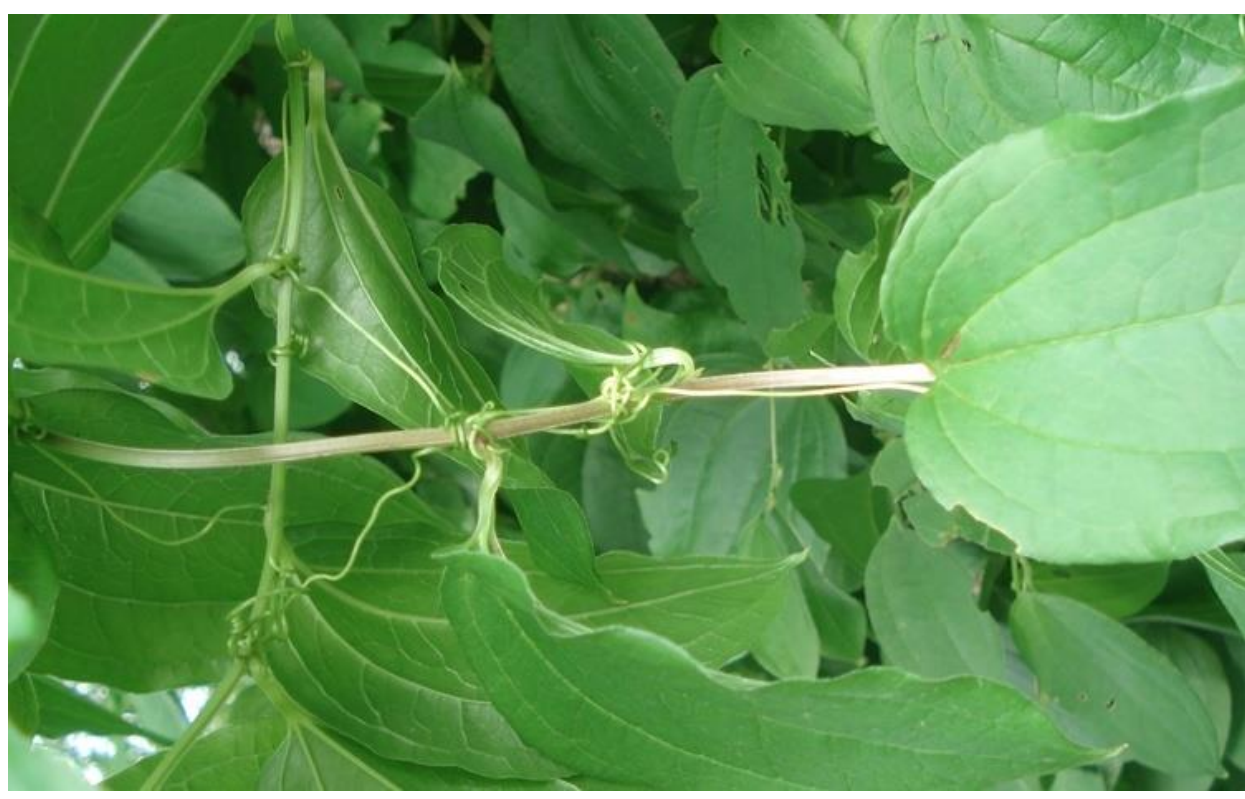

Усики сассапарили Максимовича

Некоторые лианы цепляются за опору различными выростами (шипами, эмергенцами) хмель, гумулопсис (семейство Коноплёвые). У этих растений стебли покрыты острыми Т-образными эмергенцами. Цепляться за опору могут также кустарники - например, шипов- 
ник Максимовича (семейство Розовые) и травянистые растения, например, марена сердцелистная (семейство Маревые; стебли у этого растения четырёхгранные, по граням находятся крючковидные шипы).

Особо следует сказать о княжиках и ломоносах из семейства Лютиковые - они цепляются черешками своих листьев, причём после того, как черешок обвил опору, он утолщается и становится более прочным.

Есть в Приморье и вьющиеся лианы - в поисках опоры они совершают вращательные круговые движения, и, найдя её, обвивают своим стеблем. Большинство приморских древесных лиан (виды актинидии, древогубца, кирказон маньчжурский, луносемянник даурский и др.) обвивают опоры в направлении против часовой стрелки. Лишь лимонник составляет исключение.

Травянистых вьющихся лиан гораздо больше. Они принадлежат разным семействам. Так, исключительно лианами являются представители семейства Вьюнковые - виды вьюнка (полевой и китайский), повоя (даурский, плющевидный, вздутый, слабовьющийся и сольданелловый), ипомеи (пурпуровой, плющевидной, неполной и сибирской), квамоклита (перистого и ярко-красного).

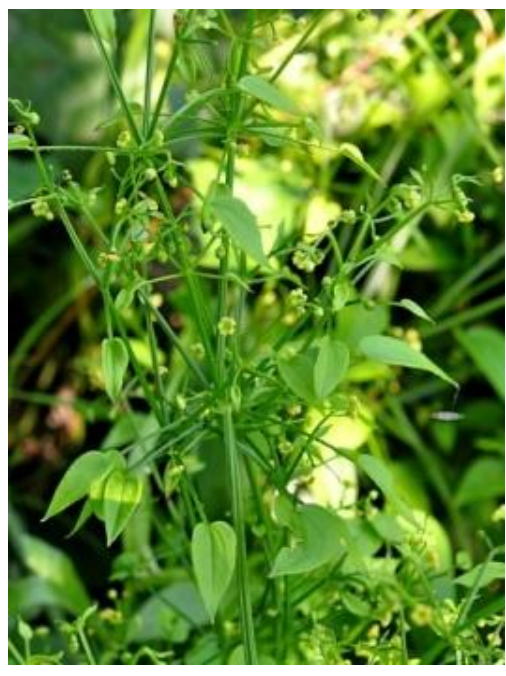

Марена сердцелистная (https://m.ok.ru)

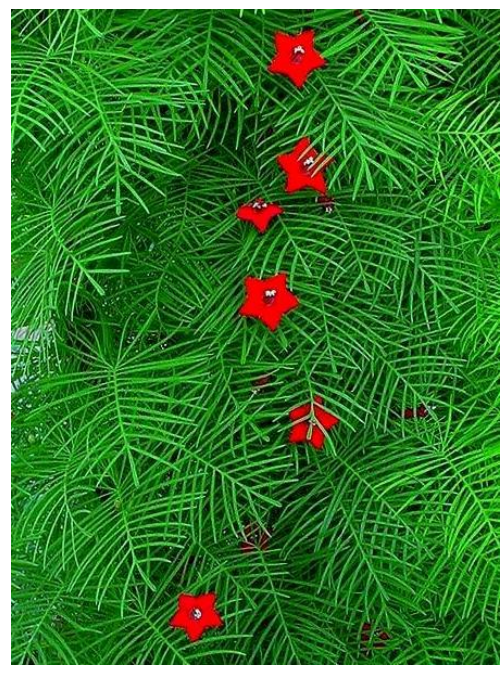

Квамоклит перистый (https://img.7dach.ru)

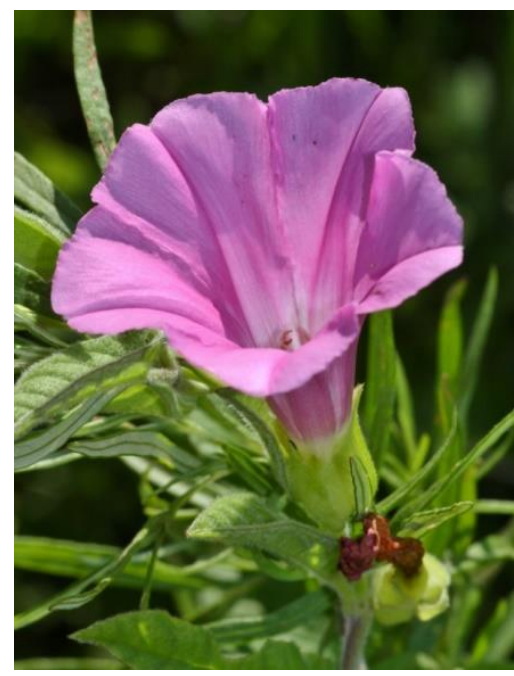

Повой даурский (https://www.plantarium.ru)

Из гречиховых вьющиеся стебли имеются у видов гречишки (зубчатокрылой, кустарниковой, Шишкина и наиболее часто встречающейся вьюнковой). Имеются лианы в семействах Диоскореевые (диоскорея ниппонская), Ластовниковые (метаплексис японский, ластовень вьющийся, сейтера Вильфорда).

\section{На основе взаимопомощи}

Взаимопомощь в мире живой природы широко распространена. Отношения, когда оба взаимодействующие организма извлекают для себя пользу, называются мутуалистическими. Раки-отшельники и актинии, моллюски и одноклеточные водоросли, травоядные животные и бактерии - все эти организмы образовали обоюдовыгодные союзы. 
А что наблюдается у растений? Оказывается, они практически не помогают друг другу. Единственный случай, когда можно говорить о взаимной пользе - явление срастания корней. Изучено оно недостаточно хорошо, в том числе и в Приморье, хотя, как считают, в природе распространено довольно широко.

Срастаются корнями самые разные виды растений. Легче всего это происходит у берёзы повислой (семейство Берёзовые), ясеня зелёного (семейство Маслиновые). А вот для дуба (семейство Буковые), сосны обыкновенной (семейство Сосновые), грецкого ореха (семейство Ореховые) необходимо, чтобы корни в течение трёх-пяти лет соприкасались между собой, прежде чем произойдет срастание. При этом направление роста корня не имеет значения - под углом они располагаются друг к другу или идут параллельно - лишь бы они достаточно плотно соприкасались друг с другом и были не слишком тонкими, лучше одного-двух сантиметров в диаметре. Выгода при срастании корней очевидна - питательные вещества при этом могут распределяться между всеми деревьями - как хорошо растущими, так и угнетенными. Правда, одновременно с питательными веществами могут переходить и ядовитые вещества (гербициды), и различные микроорганизмы. Но пользы от такого тесного сотрудничества всё-таки больше.

Еще менее изучено явление срастания ветвей. Наблюдались срастания ветвей рядом растущих растений не только одного вида, но и разных видов. В 1939 году в газете «Уральский рабочий» была помещена заметка, содержащая в себе описание двух сосново-кедровых гибридов. Один гибрид представлял собой «ствол и сучья до высоты 3-4 метра сосновые, а выше кедровые, с кедровыми шишками и орехами. Второй интересный гибрид - половина ствола от корня - сосна, а выше дерево разветвляется на два: одно ветвление сосна, другое кедр. Обе части имеют разные шишки и семена».

Благодатным материалом для начинающих бонсаистов являются мелколистные виды рода фикус (семейство Тутовые, или Шелковицевые). Наиболее распространены в комнатной культуре фикус Бенджамина и фикус притупленный. Они пригодны для формирования дерева в любом стиле. Их стволы и ветви легко гнутся даже при большой толщине. Способность к быстрому срастанию ветвей позволяет за счет посадки в один горшок нескольких растений и их скручивания быстро получить дерево нужной толщины с интересной фактурой ствола.

Гораздо чаще растения «дружат» с представителями других царств живой природы животными, грибами, бактериями. Начнем свой рассказ с дружбы растений и «малых сих»бактерий.

Как уже говорилось, для всех живых организмов жизненно необходим азот, идущий на построение белков. Растения довольствуются теми соединениями азота (ионами аммония, нитратами), которые имеются в почве. А где азота больше всего? Конечно, в атмосфере - его там свыше 70\%. Но вот беда - молекулярный атмосферный азот растениям недоступен - они не способны превращать его в «удобоваримые» соединения. Но некоторые бактерии (например, рода ризобиум) этой способностью обладают.

И вот отдельные представители растительного царства (прежде всего семейства Бобовые) решили позвать бактерий на помощь, однако не бескорыстную.

Бактерии, проникая в ткани корня бобовых, вызывают их разрастание, в результате образуются небольшие округлые образования, похожие на клубни, вследствие чего они и получили название клубеньков, а сами бактерии - клубеньковых бактерий. Таким образом бактерии получают жилище, и дополнительный источник органических веществ, которыми их снабжают растения. А само растение получило дополнительный приток соединений азота, и приток этот значителен, в результате чего бобовые являются известными кормовыми расте- 
ниями из-за повышенного содержания белков. Так, например, соя содержит до 40\% белка, больше чем его есть в мясе или яйцах. Неудивительно, что сою и получаемые из нее продукты называют «растительным мясом».

Не менее продуктивен и союз растений с грибами, который носит название микоризы. Тело гриба, как известно, представлено многочисленными ветвящимися нитями - гифами. Зачастую гифы гриба могут либо оплетать кончики корней снаружи, создавая своеобразный футляр, либо проникать в ткани корня, либо поступать двояко. При этом гриб улучшает поступление в растение минеральных веществ и воды, а растение снабжает гриб органикой. Микориза весьма распространена в природе - почти $80 \%$ всех растений планеты имеют микоризу. Растения, лишенные микоризных грибов, хуже растут и позднее приступают к плодоношению.

Более того, считают, что выход растений на сушу и закрепление на ней был бы невозможно без союза с грибами. Оказавшись более 500 млн. лет назад в совершенно новой среде, первые наземные растения столкнулись с проблемой недостатка минеральных веществ и воды. Почвы тогда еще почти не было, да и настоящие корни и водопроводящие элементы сосуды - еще не сформировались. Имевшиеся у них ризоиды предназначались лишь для закрепления в субстрате. Некоторые учёные вообще предполагают, что первоначальное значение ризоидов состояло именно для образования микоризы, и лишь впоследствии они научились самостоятельно извлекать из почвы минеральные вещества и воду. Как бы то ни было, на помощь растениям пришли грибы. Они начали поставлять минеральные элементы, прежде всего фосфорные, а сами получать синтезированную растениями органику.

Очень часто помогают друг другу растения и животные. Последние главным образом участвуют в половом размножении растений и помогают им расселяться, получая взамен вознаграждение в виде пищи.

Для того, чтобы покрытосеменное растение реализовало себя в последующих поколениях, ему необходимо образовать цветки, из которых формируются плоды, содержащие семена - зачатки будущего потомства. В цветках образуются половые клетки - мужские и женские гаметы, и чтобы появились дочерние особи, им нужно объединиться в процессе оплодотворения. А сделать это не так просто, поскольку пыльца (из которой впоследствии возникнут мужские гаметы - спермии) и зародышевый мешок (в нем созревает женская половая клетка - яйцеклетка) разъединены пространственно - пыльца образуется в пыльниках тычинок, а яйцеклетка - в завязи пестика. Чтобы произошло оплодотворение, пыльцевое зерно должно попасть на рыльце пестика, прорасти, образовав пыльцевую трубку, которая продвигается сквозь ткани рыльца, столбика и, в конце концов, попасть в зародышевый мешок, где и состоится долгожданная встреча спермия и яйцеклетки.

Казалось бы, наиболее простой путь - когда пыльца попадает на рыльце пестика того же самого цветка. Путь-то простой, но растения используют его лишь в самых крайних случаях, ибо при этом образующаяся дочерняя особь будет идентична материнской, а это весьма невыгодно в биологическом плане, поскольку отсутствует разнообразие, служащее основой для естественного отбора. То же самое произойдет, если пыльца попадёт на рыльце пестика другого цветка, но этого же растения. И в том, и другом случаях имеет место так называемое самоопыление. А вот если пыльца перенеслась на цветок другого растения, тогда все в порядке: гены одного и другого растения перемешаются, и потомство будет генетически совсем другим. Перед нами перекрестное опыление.

Для предотвращения самоопыления растения используют самые разные пути. Один из них - однополость цветков. Когда в одном цветке есть только тычинки (такие цветки назы- 
ваются тычиночными, или мужскими), а в других, женских, только пестики, самоопыления явно не произойдёт. Часто в цветках вроде бы есть и тычинки и пестики, но у одних редуцированы тычинки, и тогда они являются как бы женскими (строго говоря, они называются функционально женскими), у других - семязачатки (функционально мужские цветки).

Варьирует и представленность на одной особи различных типов цветков.

Если цветки однополые, то на одном и том же растении могут находиться как женские, так и мужские цветки - такие растения называются однодомными. Большинство растений на Земле представлено именно однодомными особями.

Может быть и так, что на одном экземпляре есть женские цветки, а на другом мужские - это свойственно двудомным растениям. Двудомность - типичное приспособление для перекрёстного опыления. Среди двудомных растений - представители семейств Ивовые (ивы, тополи и др.), Лоховые (облепиха), Крапивовые (крапивы узколистная и менее распространённая двудомная), Коноплёвые (конопля посевная, женские экземпляры которой называются матёркой, мужские - посконью) и др. Нужно сказать, что двудомных растений гораздо меньше однодомных. Ведь у них половина особей в популяции не дает семян!

Существуют и другие варианты расположения различных типов цветков. Например, на одной особи могут быть женские и обоеполые цветки (гиномоноэция, наблюдающаяся у многих Астровых), мужские и обоеполые цветки (андромоноэция, многие сельдереевые).

Также на разных особях могут быть женские и обоеполые цветки - это явление называется гинодиэцией. Она встречается у яснотковых (будры плющевидной, душицы обыкновенной, многих видов шалфея, чабреца), гвоздиковых (гвоздик, звездчаток, смолевок, синяка обыкновенного, герани луговой и лесной, короставника обыкновенного и др.). Любопытно, что у таких видов обоеполые формы имеют более крупные венчики по сравнению с женскими.

Кроме того, на разных растениях могут быть мужские и обоеполые цветки (андродиэция), что наблюдается у змеевика лекарственного (семейство Гречиховые), чемерицы Лобеля (семейство Мелантиевые); женские, мужские и обоеполые цветки (триэция, некоторые гвоздиковые). Имеют место и различные комбинации перечисленных случаев.

А что делать обоеполым цветкам? Как избежать самоопыления? Растения и здесь постарались найти подходящие способы.

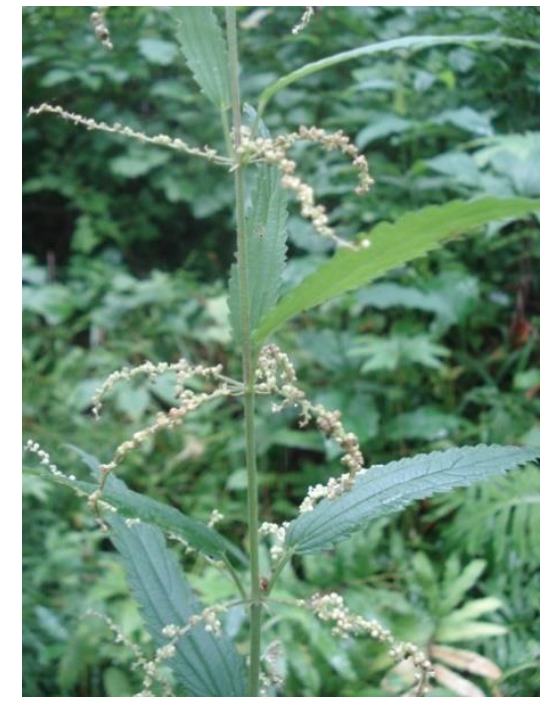

Крапива узколистная

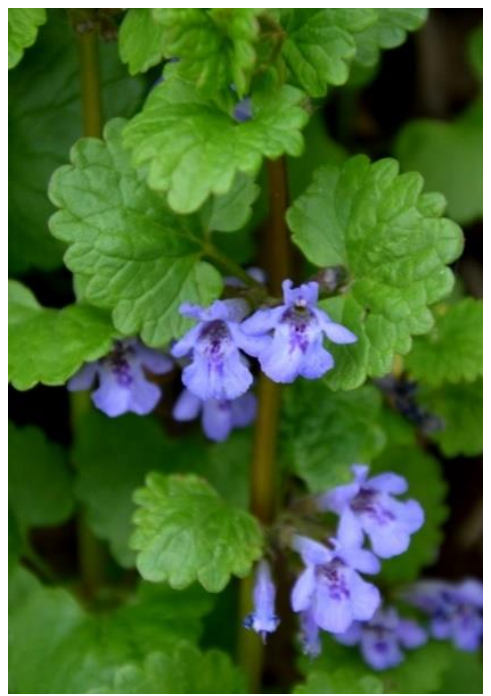

Будра плющевидная (https://nurgush.org)

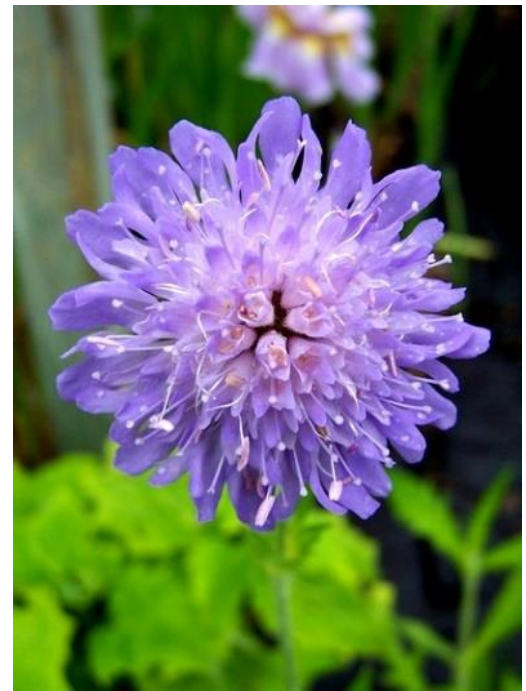

Короставник полевой (https://flowertimes.ru) 
Один из них - дихогамия, т.е. разновременное созревание пыльцы и рыльца. Если раньше созревает пыльца такой тип дихогамии называется протандрией. Она наблюдается у зонтичных, сложноцветных, колокольчиковых, гвоздиковых, губоцветных и др. Если же раньше созревают рыльца, дихогамия называется протогинией - она свойственна капустовым, розовым, барбарисовым, жимолостевым, подорожниковым и др. При таком разделённом во времени созревании вероятность попадания зрелой пыльцы на зрелое рыльце резко уменьшается.

Другой путь - гетеростилия, или разностолбчатость. В данном случае цветки имеют длинные столбики и короткие тычинки (либо наоборот). Гетеростилия наблюдается у видов незабудки (семейство Бурачниковые), первоцвета, проломника (семейство Первоцветовые), гречихи (семейство Гречиховые), вахты (семейство Вахтовые), горечавок (семейство Горечавковые). Причём варианты гетеростилии могут быть разные: например, у дербенника иволистного из одноимённого семейства наблюдаются три её формы - длинностолбчатая, когда столбик возвышается над всеми тычинками, среднестолбчатая (столбик находится посередине между длинными и короткими тычинками) и короткостолбчатая, при которой столбик короче всех тычинок.

Более распространённой является т.н. самонесовместимость. Если пыльца попала на рыльце пестика этого же цветка, то она либо не прорастает, либо через некоторое время после прорастания пыльцевая трубка разрушается. Регулируется генетически, благодаря наличию особых генов.

При этом в одних случаях все цветки у таких растений по своему строению совершенно одинаковы - это т.н. гомоморфная несовместимость. В одних случаях несовместимость связана с генетическими особенностями пыльцы (виды паслёновых, некоторых розовых - груша, яблоня, слива и др.), в других - генотипом самого растения, что наблюдается у капустовых и астровых.

У других растений самонесовместимость совмещается с гетеростилией - гетероморфная несовместимость, изучавшаяся ещё Ч. Дарвином. Она широко распространена среди мареновых, встречается у бурачниковых, первоцветовых.

Итак, к самоопылению растения прибегают в тех случаях, когда нет возможности для перекрёстного - длительное безветрие, отсутствуют насекомые-опылители и др.

Каким же образом растению доставить свою пыльцу на другое растение? Ведь рукног у него нет...

На помощь растениям могут прийти ветер или вода, но чаще всего они пользуются услугами животных, прежде всего насекомых. Нужно сказать, что инициаторами подобного союза являются растения. Они выработали самые разнообразные приспособления, иногда поражающие воображение, чтобы залучить к себе насекомых. Последние, соблазненные тем или иным способом, садятся на цветок, захватывают определённое количество пыльцы и несут ее на другой цветок, способствуя таким образом перекрестному опылению. Вероятно, насекомые трудятся на ниве опыления цветковых растений уже почти 100 миллионов лет! И к настоящему времени эти взаимоотношения достигли небывалого совершенства.

Чем же растения привлекают насекомых?

Основным фактором, хотя и не единственным, является использование в пищу нектара, пыльцы и других частей цветка.

Нектар богат разнообразными питательными веществами, прежде всего углеводами (в первую очередь сахарозой, глюкозой и фруктозой) и другими органическими и минеральными веществами. Концентрация этих сахаров обычно составляет 30-50\%, но, например, у 
липы она может превышать 70\%. Причём если цветки одних растений «открыты» для всех, выделяя нектар прямо на поверхность цветоложа, например, между лепестками и тычинками (нектарный диск), и тогда он доступен насекомым с различным типом ротового аппарата, то другие весьма избирательны, и нектар в их цветках доступен далеко не всем насекомым. В основном это растения со сростнолепестным венчиком из семейств Норичниковые, Бобовые и др. Нектар в таких случаях находится на самом дне сросшейся части, так называемой трубки. А у таких лютиковых, как аконит, живокость, водосбор он находится в шпорце. Добраться к такому спрятанному нектару могут, например, бабочки со своим оригинальным ротовым аппаратом, представляющим собой так называемый хоботок.

А если такого аппарата нет? Можно просто пробраться, хоть иногда и с трудом, в такой цветок и отведать нектара. Однако даже в мире насекомых имеются свои лентяи. Им не хочется трудиться, поэтому они научились... воровать нектар у цветков. Так, некоторые шмели прогрызают основание венчика и добираются до нектара, минуя утомительную операцию по исследованию цветка и собиранию пыльцы. Более того, последние исследования показали, что шмели могут обучаться воровству (то, что это воровство, несомненно - ведь перекрестного опыления при этом не происходит...). Впрочем, последние исследования свидетельствуют о том, что все не так просто. Оказывается, что «воры» нектара всё же способствуют перекрестному опылению, и в некоторых случаях весьма эффективно. Так, некоторые виды шмелей на молодых розовых однодневных цветках медуницы собирают пыльцу, способствуя опылению, а у синих пяти-шестидневных цветков нектар «воруют».

Привлекает насекомых и пыльца. Она необходима насекомым в качестве пищи для личинок, поскольку содержит самые разнообразные вещества - углеводы, белки и жиры, незаменимые аминокислоты (причём наибольшей ценностью обладает пыльца с разных растений, поскольку не у всех есть необходимые аминокислоты), витамины, пигменты, минеральные вещества.

Гораздо реже встречаются случаи, когда растения предлагают насекомым какие-то компоненты цветка - волоски, выросты лепестков и др. У некоторых орхидных, например, у венериных башмачков, насекомые используют в пищу волоски, покрывающие изнутри губу цветка. Иногда цветок привлекает насекомых не пищей, а, например, как убежище, место отложения яиц либо как строительный материал.

Однако для того, чтобы опылители все-таки прилетели за своей добычей, растению нужно просигнализировать о том, что для них есть подарок в виде нектара или пыльцы.

Одним из таких сигналов является окраска цветка. Как правило, цветки насекомоопыляемых растений имеют ярко окрашенный венчик - пионы из одноимённого семейства, шиповник (семейство Розовые), рододендрон (семейство Вересковые) и другие растения, или чашечку (княжик из семейства Лютиковые).

Причём цветок зачастую обладает особыми цветовыми «метками», указывающими на наличие нектара - это, например, тёмно-жёлтое пятно на нижней губе льнянки из семейства Норичниковые. Причём вклад вносят не только цвета видимого спектра, но и ультрафиолет.

Белую, бледно-жёлтую или светло-пурпуровую окраску имеют цветки, опыляемые ночными бабочками - они более заметны на тёмном фоне. Правда, они также к вечеру начинают издавать сильный аромат, так что какой раздражитель является первичным, ещё вопрос.

Кстати, аромат - важный сигнал растений своим опылителям. Какие же запахи привлекают насекомых? 
Изредка растения приманивают их неприятным запахом гниющего мяса - связноплодник (семейство Ароидные), кирказон из одноимённого семейства. Цветки кирказона маньчжурского, помимо того, имеют оригинальную форму, напоминая саксофон. В зеве такого «музыкального инструмента» расположены направленные книзу волоски - они мешают выбраться насекомым выбраться из цветка до созревания пыльников. А после того, как пыльца высыпалась и попала на покровы опылителей, волоски отмирают и насекомое отправляется к следующему цветку. Для гарантии цветки кирказона и окрашены в «мясной» цвет.

Чаще запах цветков обусловлен наличием аминов (метиламина, ди- и триметиламина и др.) - боярышник, рябина, калина, барбарис и др.

Но главными «дарителями» запаха являются эфирные масла. О них уже шла речь в главе о химическом составе растений.

Мы уже говорили, что насекомые могут воровать нектар. Но и растения не остаются в долгу, они также обманывают насекомых. Это весьма характерно для тропических орхидных. Их цветки могут копировать цветки нектароносных растений, цветущих в этот же период, могут по своей форме быть похожими на самок насекомых, наконец, могут выделять вещества, похожие на половые феромоны насекомых.

А другие орхидеи - некоторые китайские дендробиумы - поступают еще более хитро. Они выделяют вещества, имитирующие феромоны медоносных пчел, которых, в свою очередь, используют определённые осы для кормления своего потомства. Именно осы, привлечённые обманкой, выделяемой этими орхидеями, и опыляют их.

Наши приморские орхидеи также проявляют изобретательность. Например, у венериных башмачков цветки функционируют долго, до двух-трёх месяцев - хоть одно насекомое (в основном пчелы) да посетит один из них. Кроме того, насекомых привлекает яркое пятно на стаминодии (видоизменённые бесплодные тычинки). Прилетев на цветок и попав в сам «башмачок» (нижнюю губу), насекомое в попытке выбраться из ловушки протискивается мимо рыльца, а затем через одну из щелей между губой и стаминодием. Здесь она и облепливается липкими поллиниями. Выбравшись на волю и обсохнув, насекомое летит к следующему цветку - «квесту». 


\section{Глава 5. Расселение и распространение растений}

Каждый вид живых организмов, обитающих на нашей планете, имеет определённую область естественного распространения - ареал, за пределами которого он не встречается. Ареалы бывают разных типов и размеров - от весьма обширных, охватывающих значительную часть земной поверхности, до очень маленьких, занимающих буквально считанные метры. Например, ареалы пастушьей сумки (семейство Капустовые), мятлика однолетнего, тростника южного (семейство Мятликовые) охватывают не менее трети земной суши, а вот мегадения пещерная, миниатюрное растение с укороченным стеблем до 2 см высоты из семейства Капустовые, известна всего из одного местонахождения на юге Приморского края, на хребте Лозовый (Партизанский район), где она растёт на известняках под сводами пещеры.

Растения с небольшими ареалами называются эндемичными. При этом причины существования у каждого эндемика локального ареала различны. У одних растений он явился результатом сокращения прежнего, иногда весьма обширного, ареала. Например, представители рода секвойя (семейство Кипарисовые), ныне произрастающие на относительно небольшом участке атлантического побережья США, ранее встречались по всей Евразии и даже в Австралии. В то же время у молодых, недавно возникших видов (ведь процесс видообразования продолжается!) он небольшой просто потому, что они еще не успели достаточно широко расселиться. В первом случае мы имеем дело с так называемыми палеоэндемиками, во втором - с неоэндемиками. В нашей стране районами неоэндемизма являются Крым, Кавказ.

Чаще всего небольшие ареалы имеются у видов, изолированных пространственно (на островах, горных вершинах) или экологически. Например, очень маленьким ареалом, порой занимающим всего одну гору, обладают некоторые кавказские жужелицы-бомбардиры. Локально распространены также многие троглобионты - обитатели пещер.

Конечно, в отдельных случаях организмы могут встречаться и за пределами своего естественного ареала - но это возможно лишь непосредственном участии (вольном или невольном) человека. Организмы, которые являются для него полезными, он внедряет (интродуцирует) на территории, где они ранее не обитали, но где имеются подходящие для их жизнедеятельности условия. В наибольшей степени развита интродукция растений - большое число пищевых, лекарственных, технических растений ныне выращивается по всему миру, далеко за пределами их естественных ареалов. Интродуцируются и животные; одним из ярких примеров является ондатра, в 1905 году ввезённая из-за своего ценного меха из Северной Америки в Европу и затем распространившаяся на большей части Евразии.

Ареалы не являются стабильными и неизменными - их размеры, конфигурация и другие характеристики могут со временем меняться.

Формирование ареалов, а также расширение их площади происходит в результате расселения, которое представляет собой неизбежное следствие размножения. Действительно, если дочерние особи будут оставаться рядом с материнскими, то пространства и ресурсов на всех может и не хватить. Не зря, например, хищные птицы выгоняют своих оперившихся птенцов за пределы гнездовой территории. Это же свойственно и млекопитающим - главным образом хищным и копытным. Таким образом решается проблема перенаселения, а заодно происходит завоевание новой территории.

Выполняет расселение и другие функции. При расселении особи распределяются на занимаемой территории более или менее равномерно, что ведёт к снижению конкуренции. Оказываясь в иных местообитаниях, организмы подвергаются действию изменившихся факторов среды, при этом изменяются и сами, образуя новые формы, популяции. Наконец, рас- 
селение помогает «убежать» от неблагоприятных условий. А растениям, к тому же, расселение облегчает перекрестное опыление, что отмечал еще Чарлз Дарвин.

\section{Пути расселения растений}

Многие растения довольно успешно расселяются с помощью вегетативных органов. Они обычно называются вегетативно подвижными. Распространение происходит с помощью клубней, луковиц, корневищ, корневых отпрысков, надземных и подземных столонов. Чаще всего расселение (и одновременно размножение) происходит путём разрастания вегетативных органов.

Один из подобных путей - образование корневых отпрысков. В этом случае на более или менее горизонтальном корне образуются придаточные почки, которые, прорастая, образуют надземный облиственный побег. Одновременно образуются и придаточные почки. В целом получается, что на корне сформировалось дочернее растение (корневой отпрыск), находящееся на некотором расстоянии от материнского. После отделения от своего «родителя», обычно в результате перегнивания тканей, отпрыск становится самостоятельным организмом. Впоследствии он также даёт отпрыски - так постепенно расширяется территория, занятая растениями. Корневые отпрыски образуются как у древесных, так и травянистых растений.

В Приморье корнеотпрысковыми деревьями являются представители семейств Розовые, Ивовые, Берёзовые, Лоховые. Типичным растением, дающим отпрыски, является черёмуха обыкновенная (семейство Розовые). Растёт она по долинным лесам, нередко культивируется как декоративное растение. Наверное, каждый мог наблюдать рядом с деревом большое число обычно небольших корневых отпрысков. Это же характерно и для черёмухи Маака, растущей по берегам рек в хвойных и хвойно-широколиственных лесах. Из других розовых отпрыски образуют рябина амурская, боярышник перистонадрезанный. Среди ивовых образованием обильных отпрысков отличается осина (тополь дрожащий), да и другие виды тополя формируют их в достаточном числе. Многочисленные корневые отпрыски образуют виды ольхи из семейства Берёзовые - ольха волосистая, произрастающая по долинным лесам, и японская, встречающаяся главным образом по морскому побережью. Представитель лоховых облепиха, культивируемая в качестве плодового растения, также известна образованием обильных отпрысков, которые появляются в радиусе до 8 метров от материнского растения. Наконец, широко распространённый в Приморье интродуцент из семейства Бобовые робиния ложноакациевая («белая акация») образует многочисленные корневые отпрыски, которые могут сплошь покрывать значительную площадь.

Среди трав формирование корневых отпрысков отмечается у представителей семейств Астровые (осот полевой, молокан татарский, виды бодяка - полевой и щетинистый), Гречиховые (щавелёк обыкновенный), Норичниковые (льнянка обыкновенная), Кипрейные (иванчай узколистный), Вьюнковые (вьюнок полевой) и др.

Часто травянистые корнеотпрысковые растения являются злостными сорняками, избавиться от которых довольно трудно. А отпрыски, образующиеся у деревьев, широко используются для искусственного вегетативного размножения. Чего проще - отделил отпрыск, отсадил его, и получил до 10-20 новых растений от одного материнского. 


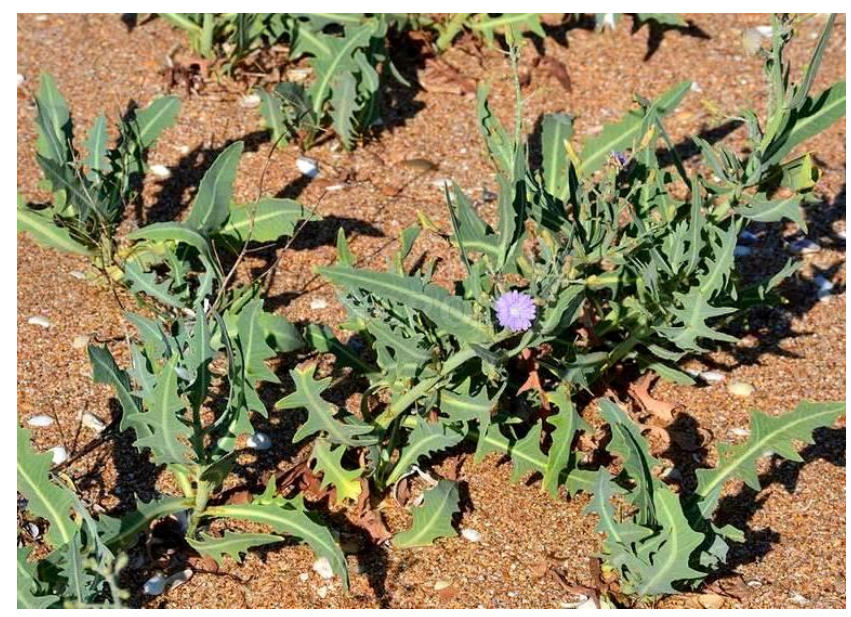

Молокан татарский (https://agrostory.com)

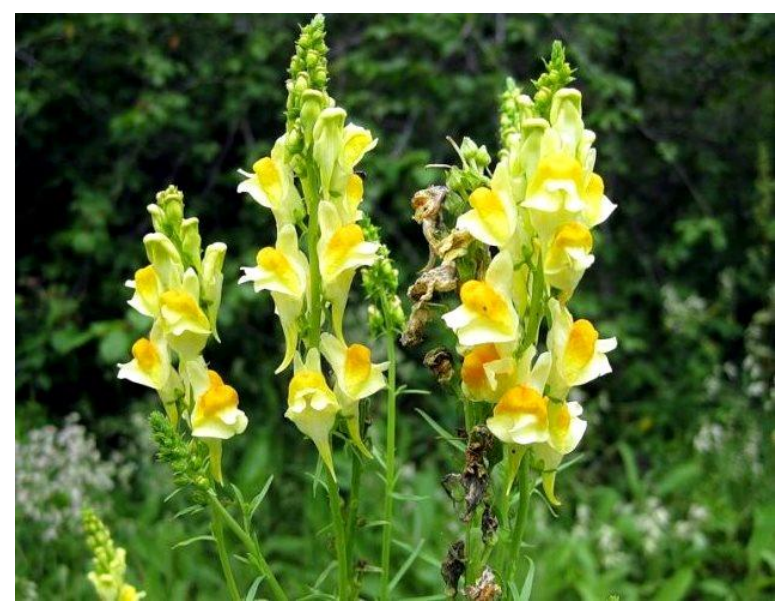

Льнянка обыкновенная (https://kursi-floristiki.ru)

Другой путь расселения как результат разрастания вегетативных органов - образование столонов (удлинённых надземных либо подземных побегов).

Надземные столоны представляют собой недолговечные стелющиеся побеги с удлиненными междоузлиями. Кроме того, они несут листья и осуществляют функцию фотосинтеза. Надземные столоны свойственны довольно большому числу растений (часто видовым эпитетом для них служит слово «ползучий») из различных семейств. Один из примеров - хоризис ползучий из семейства Астровые, растущий по пескам и галечникам морского побережья.

Среди надземных столонов обычно различают плети и усы. Плети - это столоны, несущие обычные ассимилирующие листья. Концы плетей, укореняясь, образуют подземную часть с укороченным стеблем (розетку), из которой возникают новые плети. С отмиранием междоузлий розетки становятся самостоятельными растениями.

Плетевидные побеги есть у растений семейства Яснотковые (Губоцветные): михении крапиволистной, будры плющевидной, будры длиннотрубчатой, видов рода зюзник. У селезеночника усатого из семейства Камнеломковые в основании стебля образуется до пяти густо облиственных стелющихся и укореняющихся побегов до 18 сантиметров длины. Плети образуют также сердечник лировидный (семейство Капустовые), лужница водяная и губастик отпрысковый (семейство Норичниковые), тригонотис укореняющийся (семейство Бурачниковые).

Более специализированные столоны, обычно лишенные листьев, с очень длинными междоузлиями, называют усами. Усы свойственны, например, видам земляники и лапчатке гусиной из семейства Розовые.

Усы земляники восточной, широко распространённой в Приморье, составляют в среднем 25-30 сантиметров (могут достигать 50-55 сантиметров) длины и 0,1-0,12 сантиметров в диаметре. Они несколько красноватые (особенно на ярком солнце), опушённые волосками до 0,8 сантиметров длины. От стебля отходит столон, вначале направляясь вверх, затем полегая и стелясь по почве. От материнского растения до первой образовавшейся розетки образуются два междоузлия - первый 12-27 сантиметров длины, второй 13-25 сантиметров длины. В узле, разделяющем материнское растение и дочернюю розетку, имеется почка, защищаемая видоизменённым листом. Иногда почка идет в рост, и тогда столоны начинают ветвиться. Дочерних розеток может образоваться 2-4. Чем ближе к верхушечной почке столона, тем ко- 
роче становятся междоузлия; так, междоузлия, разделяющие очередную дочернюю розетку и верхушечную почку, составляют в среднем соответственно 11 и 4 сантиметров. Верхушечная почка также скрыта листьями формирующегося побега.
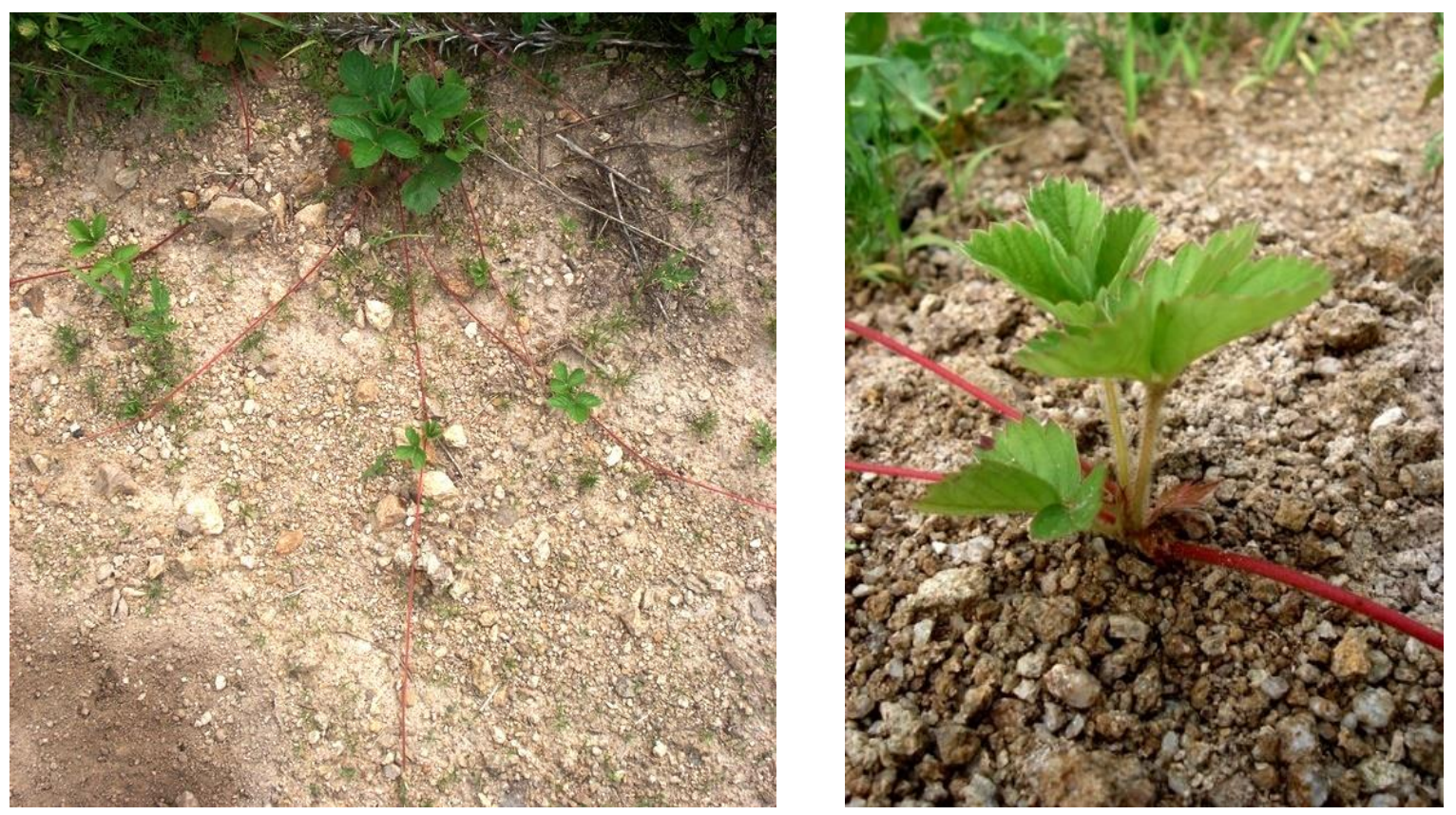

Усы земляники восточной и образовавшаяся дочерняя особь (Рыбакова, Коляда, 2020)

Этой же цели завоевания территории и вегетативного размножения служат подземные столоны. Тонкие длинные столоны развиваются у турухании Шишкина (семейство Бобовые), энемиона Радде (семейство Лютиковые), трижелезника японского (семейство Клузиевые), жёлтокислицы ручьевой (семейство Кислицевые), многих представителей семейства Первоцветовые. При этом у большинства растений они беловатые, а у трижелезника и вербейника даурского из семейства Первоцветовые - красноватые.

У некоторых растений столоны, как у картофеля, заканчиваются клубнями. Это характерно для стрелолистов трёхраздельного и плавающего из семейства Частуховые, двулепестников альпийского и стеблеватого из семейства Кипрейные, седмичника европейского из семейства Первоцветовые.

У ряда растений имеются достаточно тонкие, длинные корневища, которые распространяются на большое расстояние от материнского растения. В узлах таких корневищ образуются придаточные корни. В один прекрасный момент почка, находящаяся в узле, начинает прорастать и формирует надземный побег. Образуется так называемый корневищный отпрыск. Если впоследствии связь отпрыска с материнским растением утрачивается (чаще в результате перегнивания), то образуется новое растение, причём оно будет находиться на некотором расстоянии от материнского, нередко достаточно большом. Оно также образует отпрыски, те - новые и так далее; таким образом, постепенно осваиваются новые участки.

Корневища, служащие главным образом для вегетативного размножения, имеются у целого ряда видов. Довольно часто они встречаются у гигрофитов - растений, обитающих в условиях повышенной влажности, часто полупогруженные в воду. Среди них - виды рода клубнекамыш (семейство Сытевые), весьма эффективно размножаются корневищами лотос Комарова, аир болотный из одноимённых семейств. 
Среди мезофитов, размножающихся таким образом, можно упомянуть повой американский (семейство Вьюнковые), мяту полевую (семейство Яснотковые), пырей ползучий, тростник южный (семейство Мятликовые), хлорант (семейство Хлорантовые), горянку корейскую (семейство Барбарисовые), подмаренник удивительный (семейство Мареновые), кислицу обыкновенную (семейство Кислицевые).

Зюзник блестящий (семейство Яснотковые) имеет шнуровидное, тёмно-бурое корневище, укореняющееся в узлах и распространяющееся до 10-12 метров. У ряда видов полыни из семейства Астровые (красночерешковой, обыкновенной, побегоносной) корневище ползучее, с подземными укореняющимися побегами и многочисленными надземными бесплодными стеблями.

У тладианты сомнительной (семейство Тыквовые) у подземных побегов формируется цепочка клубней до 8 см длины, из которых следующей весной образуются новые побеги. Клубни могут формироваться и у надземных, расположенных низко над почвой, стеблей. Таким об-

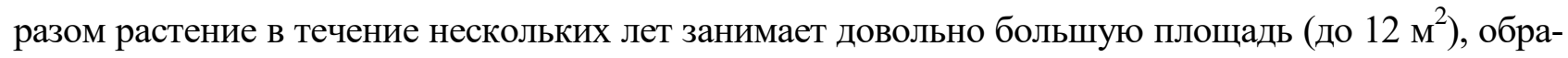
зуя густую и быстро увеличивающуюся в объёме куртину.

Чаще растения для расселения используют другой путь - отделение от своего тела какой-то части, из которой впоследствии возникнет новая особь. Эту часть, своеобразную единицу расселения, ботаники называют диаспорой.

В качестве диаспор могут выступать как генеративные, так и вегетативные органы растений, причём первые идут в ход наиболее активно.

Вегетативные диаспоры чаще всего образуют луковичные растения. Луковицы - запасающие структуры, представляющие собой видоизменённые органы. О них уже говорилось выше. На луковице нередко образуются дочерние луковички, которые впоследствии отделяются и вырастают в самостоятельные растения. Так размножаются, например, многие лилиевые.

Особый случай представляет живорождение, или вивипария - формирование на материнской особи мелких дочерних растений, развивающихся в большинстве случаев из так называемых выводковых почек (ещё один тип вегетативных диаспор). Наиболее знакомый пример - бриофиллум (семейство Толстянковые), ряд видов которого встречается в комнатной культуре, а один из них, бриофиллум Дегремона, из-за своих лечебных свойств нередко называется домашним, или комнатным, женьшенем. У этих растений по краям листьев из придаточных почек образуются маленькие растеньица, которые легко отделяются, падают на почву и укореняются. Живорождение наблюдается и у папоротника асплениума (семейство Костенцовые), также довольно частого гостя в наших квартирах. Оригинальный пример вивипарии демонстрируют некоторые виды растений мангровой зоны - авиценния (семейство Акантовые), ризофора (семейство Ризофоровые). Семена у них прорастают прямо в плоде. Проросток, у которого гипокотиль достигает 50-70 см, довольно тяжёлый, в определённый момент он отрывается и своеобразным дротиком падает в илистый субстрат, где и происходит его дальнейшее развитие.

Довольно часто живорождение наблюдается у злаков и луков. У них выводковые почки формируются в соцветиях. Для злаков вивипария является приспособлением к короткому увлажненному вегетационному периоду и характерна для северных широт.

Из растений Приморья вивипария встречается у мятлика сплюснутого (семейство Мятликовые), лука крупнотычинкового (семейство Луковые), змеевика живородящего (семейство Гречиховые), очитка живородящего (семейство Толстянковые). 
У некоторых растений выводковые почки формируются в пазухах листьев. Это наблюдается, например, у лилии ланцетолистной, или тигровой (семейство Лилиевые) - ее луковички широкояйцевидные, почти округлые, до 1,5 см в длины и ширины, тёмнокоричневые, почти чёрные, голые, блестящие. На луковице, еще находящейся на материнском растении, образуются корни, в начале развития один крючковидный, до 1,5 мм в диаметре, зелёный, затем их число увеличивается в среднем до двух. Опадая впоследствии, луковицы образуют новые растения. Оказавшись на почве, луковицы укрепляются с помощью вновь образуемых корней, часть из которых является контрактильными. Последних насчитывается 3-4, утолщённых, неветвистых, в основании поперечно морщинистых, до 2,5(3) см длины и 0,25 см в диаметре, беловатых. Эти корни углубляют луковицу в почве на 2-4 cм.

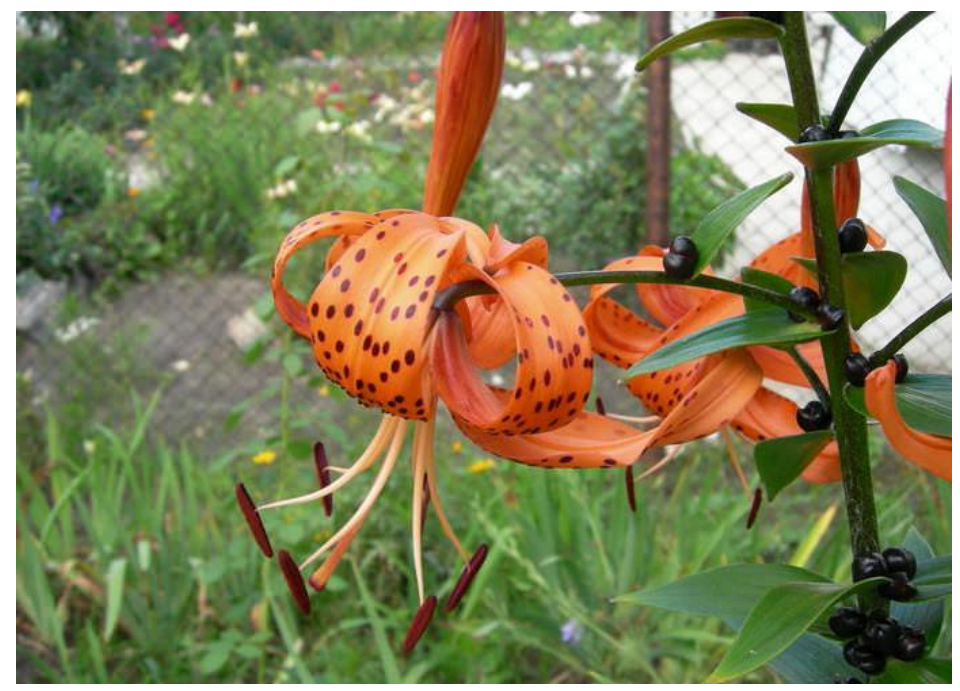

Луковички лилии тигровой (https://dachadecor.ru)

В пазухах листьев образуются мелкие клубни и луковички у лапортеи клубненосной (семейство Крапивовые), а также стрелолиста Агинаси (семейство Частуховые), очитка живородящего (семейство Толстянковые), камнеломки наклонённой (семейство Камнеломковые).

Если же говорить о диаспорах, представленных генеративными органами, то, например, у цветковых растений это семена, плоды, отдельные части плода, наконец, соплодия. У голосеменных - шишки или семена. Наконец, у споровых растений (мхов, хвощей, плаунов, папоротников) расселение происходит с помощью спор - мелких одноклеточных образований, окруженных плотной оболочкой. Споры легко подхватываются ветром и переносятся на различные расстояния. Попав в конце концов на почву, споры при благоприятных условиях (наличии воды, прежде всего) прорастают, образуя либо новые растения (у мхов), либо заростки (гаметофиты), на которых впоследствии образуются новые особи (спорофиты).

Существует ряд стратегий, обеспечивающих расселение растений диаспорами генеративного типа.

\section{Обходимся своими силами}

Самым простым путем реализации принципа «опора на собственные силы» является образование массивных диаспор, чаще всего плодов. Они опадают рядом с материнским растением, впоследствии, после разрушения околоплодника, семена прорастают и дают дочерние особи. Таким образом создают свои ареалы дуб (семейство Буковые), орех маньчжур- 
ский (семейство Ореховые), груша уссурийская, абрикос (семейство Розовые), сосна корейская (семейство Сосновые) и еще целый ряд древесных видов Приморья.

С одной стороны, очевидна довольно низкая эффективность такого способа: удаление от материнской особи будет незначительным, максимум в несколько метров. Мало поможет даже наличие склона, который позволит диаспоре преодолеть чуть большее расстояние. Поэтому и расширение территории, занимаемой видом, будет крайне медленным. Но с другой стороны - куда торопиться? Шаг за шагом (или, лучше сказать, шажок за шажком) растениябарохоры (такое они носят название) завоевывают новые участки для проживания.

Чтобы сократить время, которое требуется на высвобождение семян из плода, многие виды решили дать им свободу ещё в то время, когда плоды находятся на растении. Достигается это путем вскрывания плодов, после чего семена опадают рядом. Такой путь избрали растения с плодами коробочкой, стручком, бобом.

Коробочка встречается в самых разных семействах - Маковые, Жимолостевые, Вересковые, Колокольчиковые и многих других. И морфология их разнообразна - различны форма коробочки, число семян, способ вскрывания и др.

Распространены такие вскрывающиеся плоды, как стручок - характерный плод представителей семейства Капустовые (Крестоцветные) и боб - «визитная карточка» растений семейства Бобовые. Следует напомнить, что хотя внешне эти плоды могут быть довольно похожими - они удлиненные, сухие, содержат как правило несколько семян, вскрываются двумя створками, - между ними есть существенное различие: семена у бобовых располагаются на самих створках (вспомните горох), а в стручке есть центральная перегородка, которая и несёт семена.

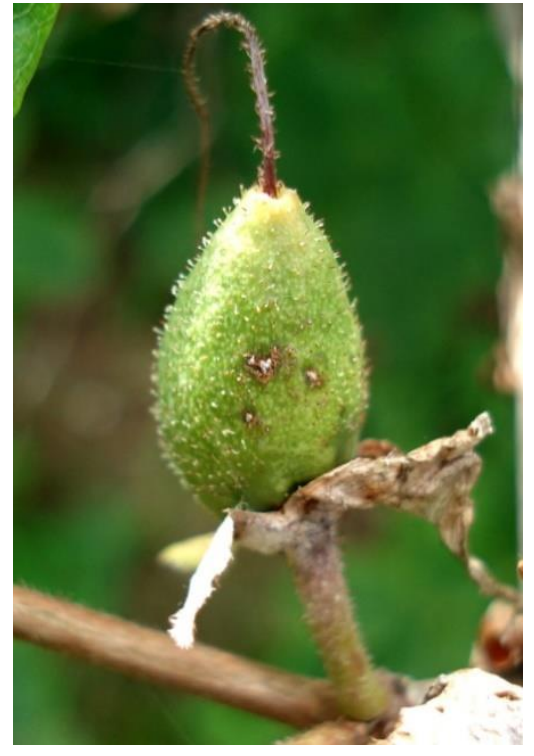

Коробочка рододендрона Шлиппенбаха

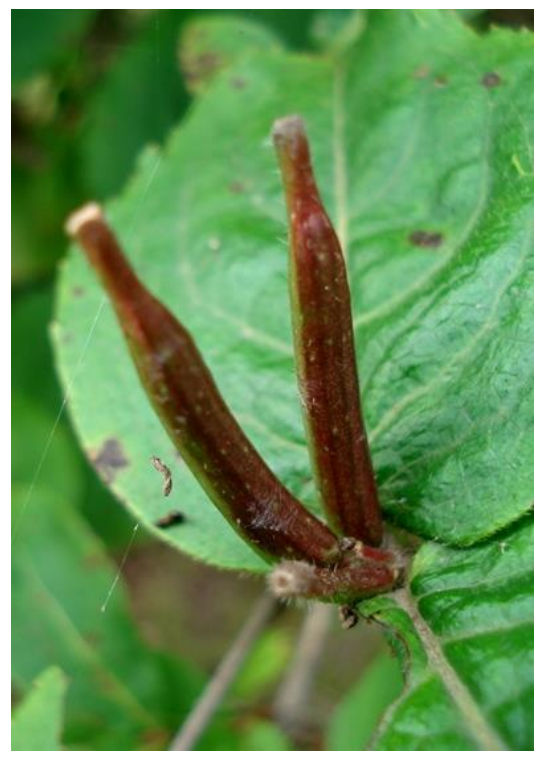

Коробочки вейгелы ранней

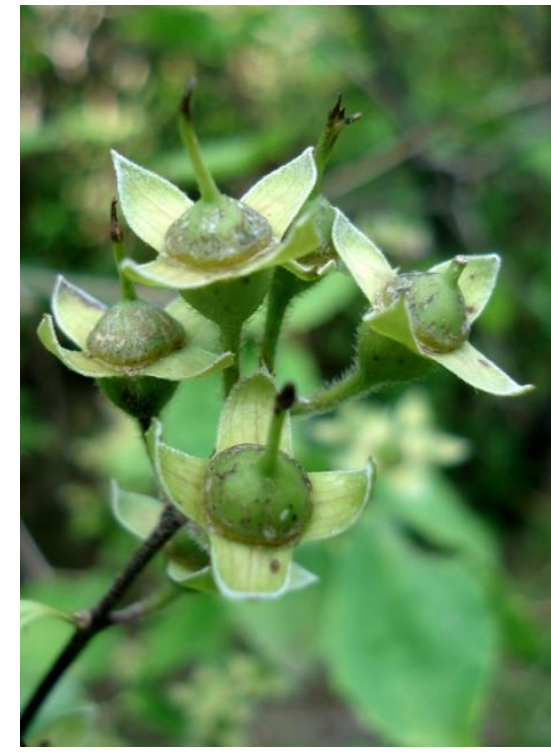

Коробочки чубушника тонколистного

Любопытно, что часто семена имеют гладкую поверхность, чтобы легко и быстро выскальзывать из околоплодника.

Растения, у которых плоды раскрываются, а семена из них высыпаются либо под действием ветра, либо при механическом воздействии животных, называются баллистами. 
Следует отметить, что опадающие плоды часто поедаются или запасаются животными, которые разносят диаспоры на различные расстояния. И наоборот, если животные не озаботились выполнением своей роли разносчиков диаспор, последние просто опадают рядом и впоследствии прорастают. Так происходит сочетание различных способов расселения. Другие примеры такого сочетания - когда мелкие семена, выпавшие из плода, подхватываются ветром и разносятся им или когда животные, касаясь созревших плодов, вызывают их раскрывание (при этом последовавший «залп» может усеять семенами всю шерсть).

Как еще повысить эффективность расселения (читай - увеличить дальность удаления диаспор), полагаясь лишь на себя? Остаётся один путь - «выстрелить» своими диаспорами как можно дальше. При этом растениям приходится потрудиться, чтобы добиться желаемого результата.

Выделяют целую группу растений, которые способны «забросить» свои диаспоры довольно далеко по сравнению с собственными размерами. Они обитают обычно там, где другие способы расселения неэффективны - например, под пологом густого леса, где практически отсутствует ветер. Из самых знакомых примеров - кислица, герань из одноименных семейств, недотрога (семейство Бальзаминовые). Они не только относятся к разным семействам, но и механизмы «стрельбы» у них разные.

В комнатном цветоводстве широко используется кислица обыкновенная (семейство Кислицевые), но нередко встречаются и другие виды этого рода. Когда семена кислицы созревают, достаточно слегка коснуться коробочки - она «взрывается», и семена разлетаются на десяток-другой сантиметров, а иногда и дальше. Кислица демонстрирует нам один из механизмов «стрельбы». Успех ее зависит от наличия двух типов тканей - одна способна, интенсивно впитывая воду, сильно набухать, а другая, плотная, до поры до времени сдерживает это набухание. И вот когда превышен предел сдерживания либо сработал внешний фактор (касание, порыв ветра), происходит «выстрел».

В семенах кислицы наружный слой семенной кожуры прочный, а внутренний состоит из клеток, богатых сахарами. После созревания семян внутренний слой набухает, создается давление, которое разрывает внешний слой. Семена резко отбрасываются к оси коробочки, отскакивают от нее и вылетают через щель в околоплоднике.

В Приморье произрастают два вида кислицы - обыкновенная и обратнотреугольная. Это небольшие, до 20 см корневищные травы с тройчатосложными листьями, произрастающие в хвойных и смешанных лесах.

У недотроги обыкновенной происходит сильное натяжение створок, которые, разрываясь, резко завертываются вовнутрь, выбрасывая семена. Это же наблюдается у сердечника белоцветкового (семейство Капустовые), только у него створки закручиваются кнаружи.

Аналогичным механизмом пользуются и герани. Внутри их длинного плода проходит стержень, к которому прикреплены четыре прямые и соединённые вместе створки - сверху они держатся прочно, снизу слабо. При созревании нижние концы створок отрываются от основания, резко скручиваются к вершине стержня и разбрасывают семена.

Могут совершать «стрельбы» семенами и бобовые. Так, у видов чины, караганы, вики створки боба могут с силой скручиваться в спираль, и семена отбрасываются на некоторое расстояние. Само скручивание вызвано различным направлением фибрилл целлюлозы в створках.

У единственного на Дальнем Востоке древесного представителя семейства Молочаевые секуринеги полукустарниковой, произрастающей по скалам, на известковых отложениях, характерен плод регма. Он небольшой, до полусантиметра в диаметре, округлый. После 
созревания и высыхания он с силой распадается на три «плодика» (мерикарпия), которые разлетаются на небольшое, до одного метра, расстояние.

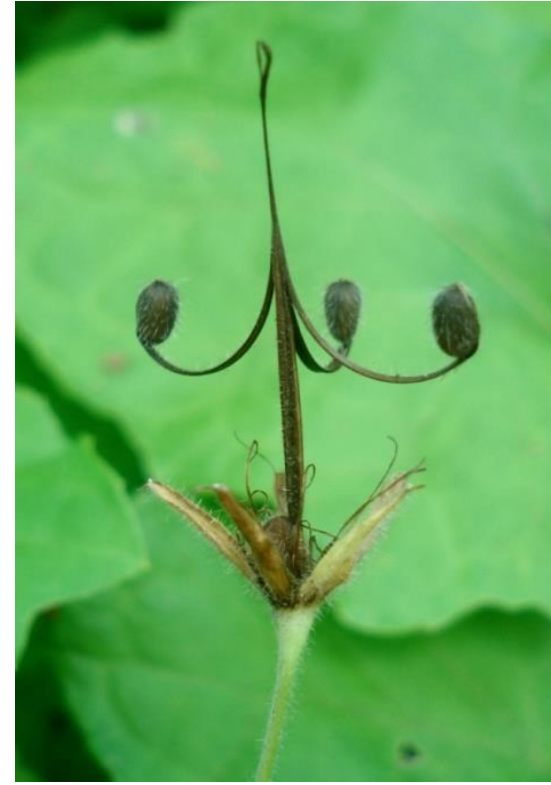

Раскрывшийся плод герани

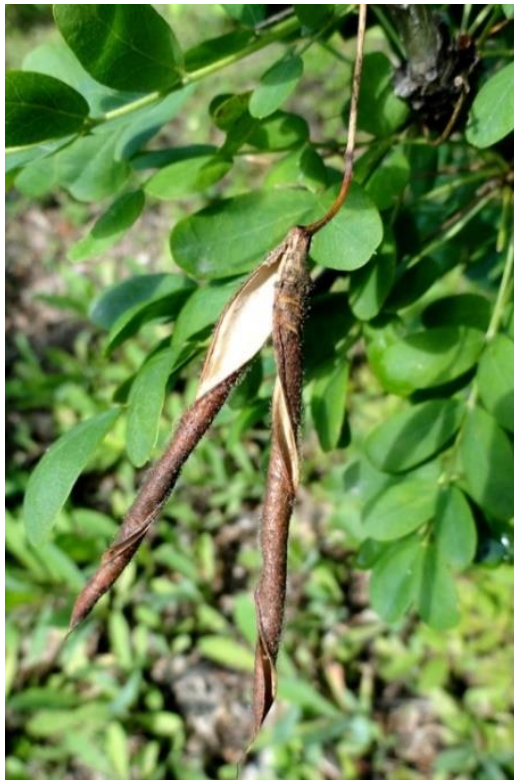

Раскрывшийся боб караганы древовидной

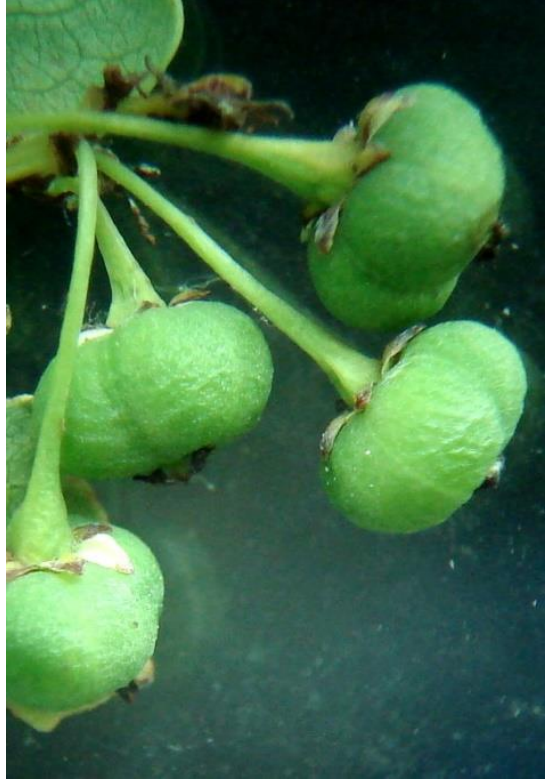

Плоды секуринеги полукустарниковой

Конечно, нашим растениям далеко до такого признанного «метателя», как экбаллиум пружинистый из семейства Тыквовые (известный как «бешеный огурец») или некоторые тропические бобовые. В созревшем плоде бешеного огурца, например, создается значительное давление - до пятнадцати атмосфер. И тогда достаточно порыва ветра или касания животного - плод тотчас же отрывается от плодоножки, и его содержимое вместе с чёрными семенами выбрасывается на десять-двенадцать метров! Любопытно, что при «выстреле» реактивная отдача толкает плод в обратном направлении. При этом он задевает другие ждущие свой очереди плоды, и тогда может наблюдаться целый «залп» содержимого плодов.

Кстати, «бешеным огурцом» называют иногда эхиноцистис лопастный из этого же семейства. Он родом из Северной Америки, у нас это заносной вид, растёт по сорным местам и пустырям, культивируется и дичает. Плоды его до пяти сантиметров, зелёные, покрытые эмергенцами. В дождливую погоду в плодах накапливается вода, давление возрастает, околоплодник разрывается и два плоских семени вылетают на небольшое расстояние. Чаще, однако, семена под действием ветра просто высыпаются из двух отверстий на верхушке плода. Еще более скверным стрелком из тыквовых является схизопепон бриониелистный - его плод при созревании распадается на три створки, из которых просто выпадают три буроватых плоских семени.

Но любой бешеный огурец спасует перед хурой взрывающейся из семейства Молочаевые, произрастающей во влажных тропических лесах Южной Америки. Она разбрасывает семена метров на сорок-сорок пять, а по некоторым сведениям - и на все сто метров, со скоростью до 70 метров в секунду! Плод при этом лопается с громким звуком, что и послужило причиной назвать его «динамитным деревом».

Плоды некоторых растений, попав на почву, не просто пассивно ожидают дальнейших событий, а стараются получше «устроиться» в этом мире. Так, диаспоры ряда злаков 
(эгилопса, ячменя), астровых (василек), лютиковых (виды ломоноса) могут «проползти» некоторое расстояние, пока не найдется тихое и мирное пристанище - какое-то углубление в почве, например - где они обретут покой и вскорости прорастут. Передвигаются они с помощью имеющихся на них волосков, которые чутко реагируют на влажность воздуха - при ее изменении они меняют свою упругость и, следовательно, ориентацию. То распрямляясь (если влажность низкая), то прижимаясь к центральной оси (если она высокая), они и служат «двигателем» диаспоры.

А у видов журавельника из семейства Гераневые плоды имеют спирально закручивающуюся ость, которая при изменении влажности может то скручиваться, то раскручиваться. Результат получается прекрасный - диаспора просто-напросто ввинчивается в почву.

Любопытный пример являет арахис (семейство Бобовые). После оплодотворения у него сильно удлиняется цветоножка, да так, что цветок достигает почвы и даже углубляется в нее. Где впоследствии и образуются плоды. Это явление называется геокарпией. Нечто похожее наблюдается у нашей звездчаточки лесной из семейства Гвоздиковые. В пазухах нижних листьев этого небольшого травянистого растения, произрастающего по хвойным и смешанным лесам, развиваются мелкие нераскрывающиеся (так называемые клейстогамные) цветки на цветоножках чуть более сантиметра в длину. Они изогнуты книзу, и впоследствии могут достичь почвы и зарыться в нее.

Кроме того, во флоре Приморского края есть и другие растения с клейстогамными цветками, находящимися в подстилке или в почве. Это амфикарпея из семейства Бобовые, некоторые фиалки (семейство Фиалковые), уже упоминавшаяся кислица обыкновенная.

\section{Летим по ветру}

Для расселения диаспор растения полагаются не только на собственные возможности, они не преминут воспользоваться услугами добровольных либо невольных помощников, в качестве которых выступают ветер, вода, а также животные и человек.

Многие растения открытых пространств решили призвать на помощь ветер, причём сделали это весьма изобретательно. В целом можно выделить три стратегии растений в отношении использования ветра для распространения своих диаспор.

Первая из них - мелкие размеры. Миниатюрная диаспора легко подхватится ветром и перенесётся им на какое-либо расстояние. Единственный возможный кандидат в этом случае семена. Из древесных растений небольшие семена образуются у рябинника рябинолистного, видов спиреи (семейство Розовые), чубушника тонколистного (семейство Гортензиевые), видов рододендрона (семейство Вересковые). Из травянистых растений мелкие семена характерны, например, для колокольчиковых, маковых. Во многих случаях такие семена еще и плоские, что значительно облегчает задачу ветру по их перенесению.

Очень мелкие, пылевидные семена развиваются у эпифитов (например, из семейства Орхидные), сапрофитов (семейства Норичниковые, Грушанковые), паразитических растений (семейства Повиликовые, Заразиховые). Например, масса одного семени повилики (их в Приморье семь видов) может составлять 0,001 г., а заразихи (в Приморье три вида) - даже 0,00001 г. Очень мелкие семена у одноцветки крупноцветковой из семейства Грушанковые около 0,0000617 г.

Вторая стратегия - формирование на диаспоре каких-либо структур, придающих ей парусность и помогающих перемещаться с помощью ветра. Это самый популярный путь использования ветра растениями. Причём эти образующиеся структуры могут быть по меньшей мере двух типов - плоскими и в виде пучка волосков. В первом случае диаспоры называются планирующими, во втором - парящими. 
Дальность полета планирующих диаспор невелика и редко превышает 100 м. Она может зависеть от двух критериев - величины крыловидного выроста (или просто крыла, как чаще говорят), и местоположения центра тяжести диаспоры, в качестве которого выступает семя.

Если семя располагается в середине диаспоры, то крылья располагаются симметрично, по ее боковым сторонам. Это свойственно концентричным диаспорам представителей семейств Берёзовые, Гречиховые, Ильмовые. При этом если у берёзовых и гречиховых крылья располагаются по бокам семени, то у ильмов они полностью окружают семя.

Следует отметить, что такого рода диаспоры не обладают особой эффективностью. Гораздо более эффективны эксцентричные диаспоры - в них крыло находится с одной стороны семени. Они встречаются у видов клёна (семейство Клёновые), ясеня (семейство Маслиновые), ели, пихты (семейство Сосновые). При этом смещение центра тяжести приводит к тому, что диаспора начинает вращаться, и дальность её полета увеличивается. Например, даже лёгкий ветерок может унести крылатку клёна метров на сто.

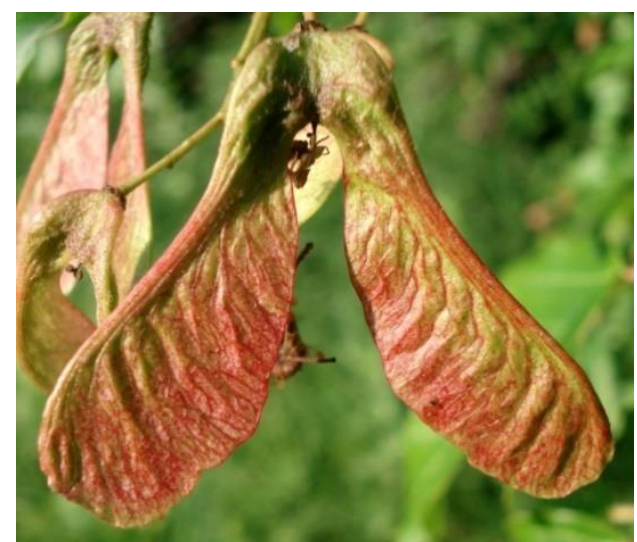

Плоды клёна приречного

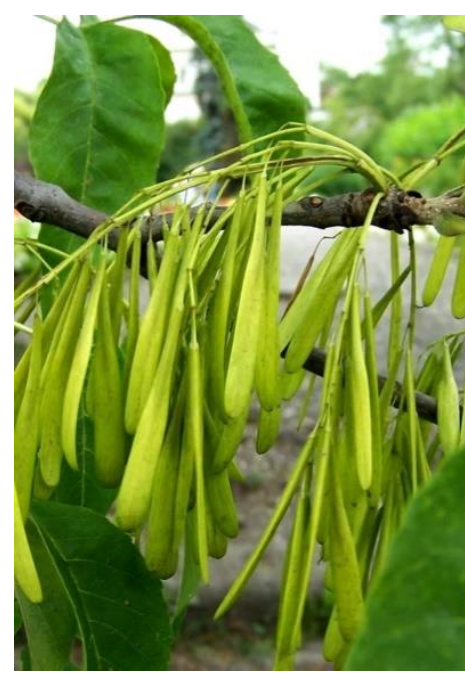

\section{Плоды ясеня \\ пенсильванского \\ (https://www.wikipedia.org)}

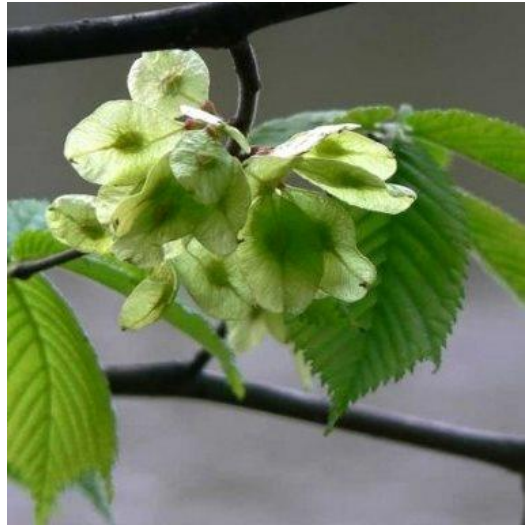

Плоды ильма

(https://www.wikipedia.org)

Оригинальны диаспоры граба сердцевидного из семейства Берёзовые. Это довольно высокое, до 20 м, дерево, произрастающее в хвойно-широколиственных лесах юга Приморья. У граба очень интересные соплодия - они очень похожи на «шишки» хмеля. Отдельный плод граба представлен небольшим, в несколько миллиметров, орешком, окруженным довольно крупным листовидным крылом (бывшей обёрткой), часть которого заворачивается и закрывает орешек.

Необычны диаспоры древесной вьющейся лианы кирказона маньчжурского из одноимённого семейства. Из-за лекарственных свойств её нещадно рубят, несмотря на то, что этот вид внесён в Красную книгу Приморского края. Одним из путей его сохранения может стать использование в озеленении, поскольку кирказон весьма декоративен - у него крупные листья, впечатляющие цветки - «саксофоны». Плод кирказона - цилиндрическая шестигранная коробочка до 10 см длины. Он содержит треугольные семена, каждое из которых имеет тонкую плёнчатую полоску (остаток эндотеция). В средней части эта полоска прикрепляется 
к верхушке семени, так что получаются два крыла до 1,7 см длины, играющие роль пропеллера. Семя при падении вращается вокруг оси по часовой стрелке и опускается на почву своим острым концом.

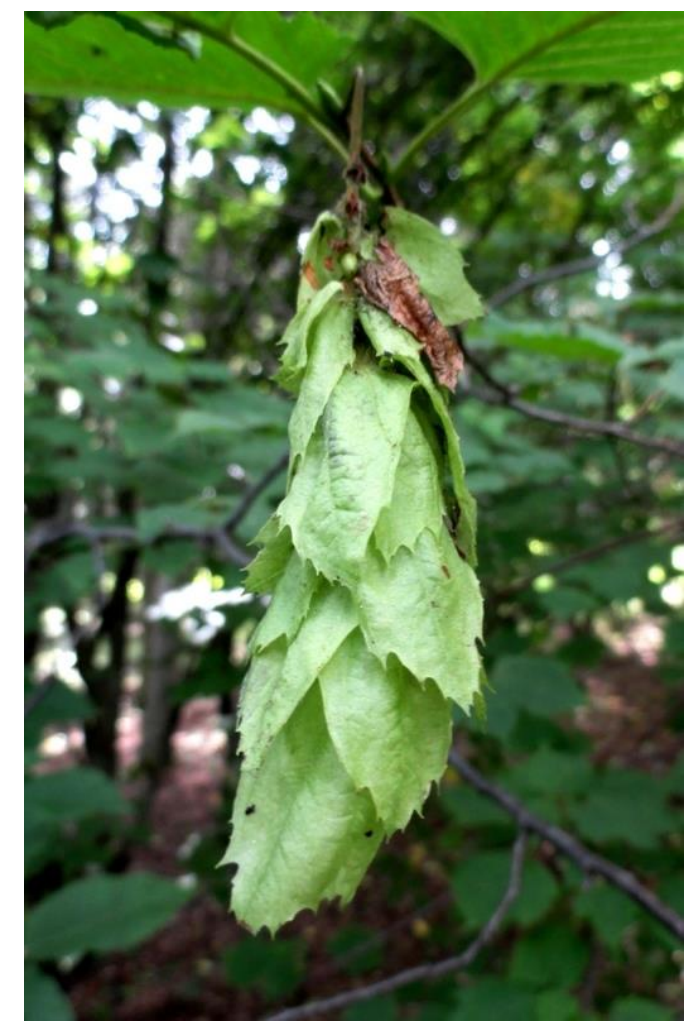

Соплодие граба сердцевидного

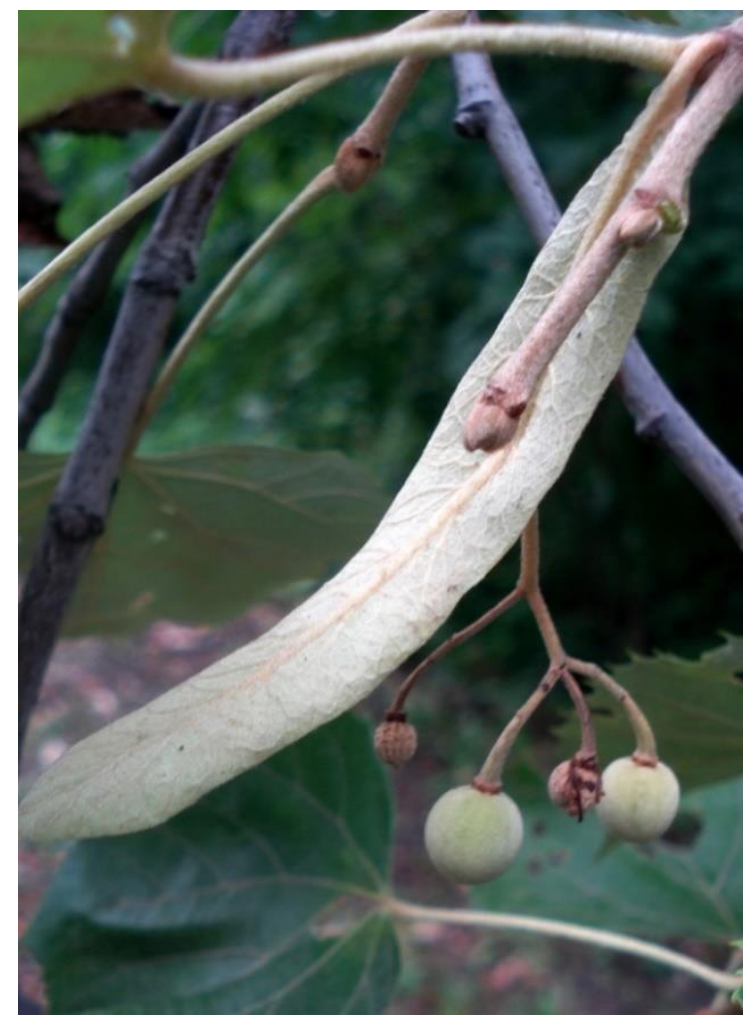

Соплодие липы маньчжурской

У приморских лип (семейство Липовые) диаспорами служат не отдельные плоды, а их совокупность, т.е. соплодие. Каждое соплодие снабжено прицветным листом, которое играет роль своеобразного паруса. Правда, его небольшие размеры по сравнению с самим соплодием не позволяют ему стать эффективным движителем при расселении.

В любом случае «окрыленные» диаспоры растений Приморья не позволяют им удалиться от материнского растения достаточно далеко. Впрочем, как мы уже говорили, торопиться растениям ни к чему.

А вот парящие диаспоры преодолевают гораздо большие расстояния. Если есть постоянный однонаправленный ветер, они могут улететь на несколько километров! Такие диаспоры имеются у представителей семейств Ивовые, Астровые, Валериановые, Злаковые, Кипрейные и некоторых других.

У ивовых пучки волосков имеют семена, а сами волоски являются выростами семяножек. Многие жители Приморья помнят то время, когда в городах с целью озеленения интенсивно высаживался тополь дельтовидный, причём использовались главным образом женские экземпляры (тополи - двудомные растения, т.е. женские и мужские цветки находятся на разных особях). Особенно много тополя дельтовидного высадили в Уссурийске. И вот когда растения достигли зрелости и приступили к размножению, жителям города пришлось несладко - множество семян, летящих по воздуху, создавали полное впечатление снегопада. Улицы были покрыты «снегом» из упавших тополиных семян и коробочек, тополиный «пух» нередко был причиной аллергических реакций у жителей города. К 
настоящему времени в большинстве случаев деревья тополя достигли предельного возраста, были вырублены, но и сегодня в разных частях города можно как стареющие, так и молодые, недавно высаженные растения.

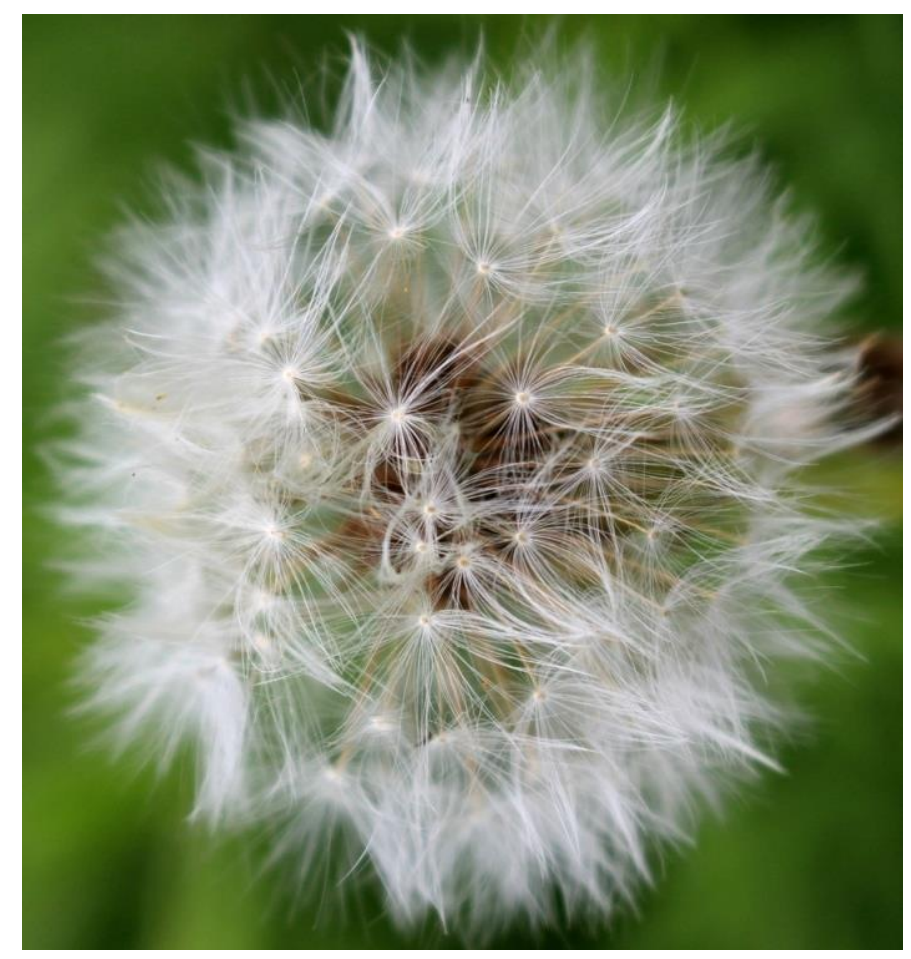

Соплодие одуванчика монгольского

У представителей семейства Астровые волоски, находящиеся на плодах, представляют собой видоизменённую чашечку. Наиболее знакомы плоды одуванчика - пучок волосков (хохолок, или паппус) у него находится на довольно длинном носике. Это же наблюдается у латука, козлобородника. Именно такие диаспоры преодолевают большие расстояния и устойчивы в полете, а кроме того, повышают подьёмную силу. У других астровых пучок волосков располагается прямо на верхушке семянки - например, у скерды двулетней, чертополоха курчавого, крестовника зубчатого, лопуха войлочного. На верхушке семян волоски находятся также у иван-чая, кипрея (семейство Кипрейные).

В основании плода волоски имеются у плодов ряда злаков - рогоза широколистного, пушицы влагалищной.

Третья стратегия использования ветра в наименьшей степени присуща растениям Приморья. У ряда видов ко времени созревания семян надземная часть приобретает шаровидную форму, отрывается от стебля (чаще всего в зоне корневой шейки), и катится, по пути роняя семена. Такие растения получили название «перекати поле». Типичный элемент пейзажа в каком-нибудь вестерне. Конечно, для таких растений необходима ровная, желательно твёрдая и свободная от растительности местность, какой в Приморье, лесном крае, маловато.

Но и здесь есть единичные представители таких растений - это некоторые виды верблюдки (семейство Маревые), например, верблюдки вытянутая и Стонтона, растущие по отмелям рек, или ячмень гривастый (семейство Мятликовые). Последнее растение для Приморья является заносным, встречается главным образом вдоль дорог, его легко узнать по свет- 
лым «метелкам». После созревания плодов колоски отделяются от сложного колоса и под действием ветра легко перекатываются по асфальту.

С некоторой степенью условности к перекати-поле можно отнести такие растения, у которых сами диаспоры перемещаются под действием ветра по снежному насту, что характерно для наших берёз, а также для кедрового стланика.

Учитывая, что ветер непредсказуем, или его вообще нет, растения образуют большое количество семян. У полыни обыкновенной из астровых их насчитывается 143 тысячи, у представителя кипрейных иван-чая узколистного - 35 тысяч.

Таким образом, растения проявляют недюжинную смекалку в использовании ветра. Однако бывают случаи, когда от самих растений ничего не зависит. Это происходит, например, при ураганах, когда с сильным ветром могут переноситься целые растения.

\section{Идем в заплыв}

Научились растения использовать и воду, точнее, ее перемещение - течения. Такой способ называют гидрохорией. Понятно, что в этом случае растения должны расти рядом с ручьем, рекой и иметь диаспоры либо с пустотами, либо с волосками, позволяющими некоторое время находиться на поверхности воды. Причём время это может быть различным - от двухдесяти дней (виды частухи, осоки, рдеста, омежника) до недель и месяцев (виды стрелолиста, поручейника). Диаспоры могут перемещаться по воде не только с течением, но и под действием ветра, что свойственно осокам (семейство Сытевые), рогозу (семейство Рогозовые).

Гидрохорами являются многие представители семейства Сельдереевые (Зонтичные), распространяемые не только водотоками, но и талой и дождевой водой. Типичные примеры виды поручейника (в Приморье их два вида), омежник яванский, вех ядовитый. У этих растений воздухоносная ткань развита в рёбрах плодов.

У плодов частуховых (виды частухи, стрелолиста) воздухоносная ткань представлена как эпидермой (наружные оболочки её недоразвиты, в результате чего образуются углубления, заполненные воздухом), так и развивающейся под ней пробкой. Под самой пробкой находится твёрдый эндокарп (внутренняя часть околоплодника), также защищающий семя от намокания.

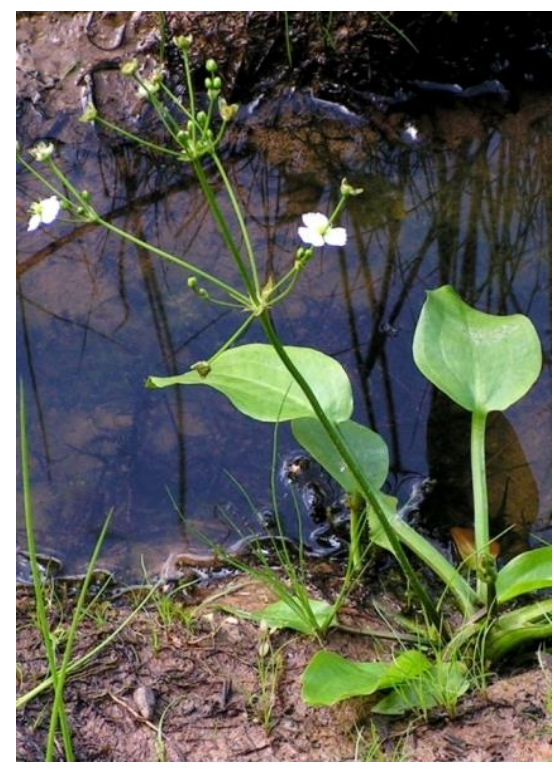

Частуха обыкновенная (https://www.wikipedia.org)

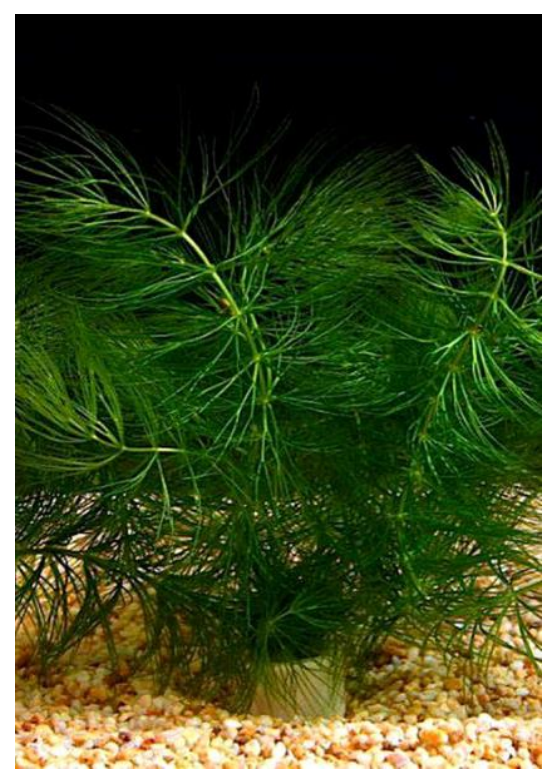

Роголистник погруженный (https://www.wikipedia.org)

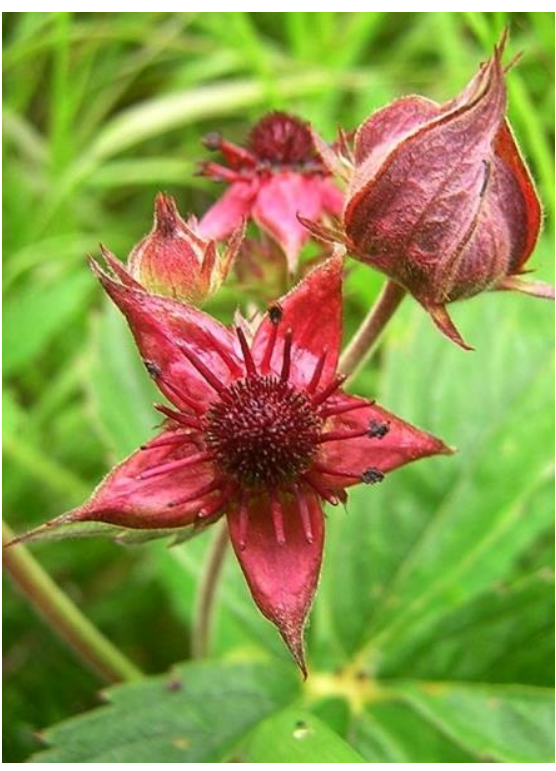

Сабельник болотный (https://tursar.ru) 
Плоды ежеголовника (семейство Рогозовые) окружены сильно утолщённой эпидермой, препятствующей проникновению воды, а под ним находится воздухоносная ткань. Плоды щавелей (семейство Гречиховые) окружены усохшим околоцветником, образующим крыловидные выросты, в которых находятся вздутия из воздухоносной ткани. У ряда кувшинковых (например, кубышки) семена окружены слизью, содержащую пузырьки воздуха, которая также способствует поддержанию их на воде. Наконец, мешочки ряда осок (семейство Сытевые), образованные сросшимися прицветниками, заполнены воздухом, что также поддерживает диаспоры на воде.

Среди древесных растений Приморья единственным гидрохором является полукустарник сабельник болотный (семейство Розовые), произрастающий по болотам, берегам рек. Его орешки падают на поверхность воды и разносятся течениями.

Условно к гидрохорам можно отнести кедровый стланик (семейство Сосновые). Он растёт в высокогорье на высоте 850-1200 м над ур. м., нередко занимая крутые склоны, главным образом на гольцах. После наступления интенсивного таяния снега и льда, диаспоры могут уноситься водами на меньшие высоты, попадая в каменноберёзовые и лиственничные леса, где из-за затенённых условий развившиеся из семян растения кедрового стланика не плодоносят.

Еще один условный гидрохор - заразиха из одноимённого семейства. Её очень мелкие семена проникают в почву с осадками.

\section{Дружба с животными}

Еще один путь расселения, более «интеллектуальный» по сравнению с остальными. В данном случае свою помощь в основном предлагают птицы и млекопитающие. Растений, решивших привлечь к распространению диаспор животных, достаточно много.

Животные обладают замечательной способностью, недоступной растениям - они могут двигаться: бегать, летать, ползать, наконец. Именно эту способность и эксплуатируют растения, проявляя в этом немалый талант. Выделяют три типа зоохории - так называют расселение растительных диаспор животными.

Один из них заключается в том, что диаспора прикрепляется к шерсти или перьям и держится некоторое время, пока «транспорт» не удалится на достаточное расстояние. Такой путь получил название эпизоохории. Эта форма зоохории имеет характер комменсализма, поскольку животные, пассивно перенося диаспоры растений, не извлекают из этого никакой пользы.

При этом прикрепиться можно различными способами, и не обязательно для этого иметь какие-то особые приспособления.

К самому простому пути прибегают растения с мелкими плодами, произрастающие на лугах, вдоль дорог, либо близ воды - подорожник большой (семейство Подорожниковые), звездчатка средняя (семейство Гвоздиковые). После осадков, когда грунт насыщен водой, диаспоры вместе с грязью приклеиваются к ногам животных и таким образом разносятся. Диаспоры других растений прикрепляются, вместе с илом и слизью, к лапкам или перьям водоплавающих птиц, что изучал еще Чарлз Дарвин. Да и человек, пройдя по влажному травостою, может внести свою лепту в расселение таких растений.

Однако более надежно диаспоры прикрепятся, если они будут иметь какие-то приспособления - химические либо морфологические.

В первом случае плоды могут выделять клейкие вещества, которые способствуют приклеиванию диаспор к шерсти животных. Из растений Приморского края наиболее знакомый пример - представитель семейства Астровые железистостебельник гималайский, часто 
называемый прилипалом. Он часто растёт по тропинкам, старым дорогам, берегам рек. Это довольно высокая трава с почти округлыми листьями. беловойлочным опушением. Семянки растения, находящиеся на длинном плодоносе, снабжены железистыми волосками, которые накапливают этот «клей», который и способствует прикреплению к шерсти животных и одежде человека.

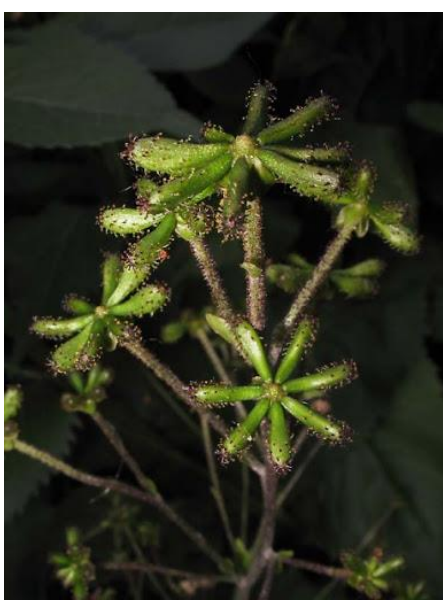

Плоды железистостебельника гималайского (https://www.wikipedia.org)

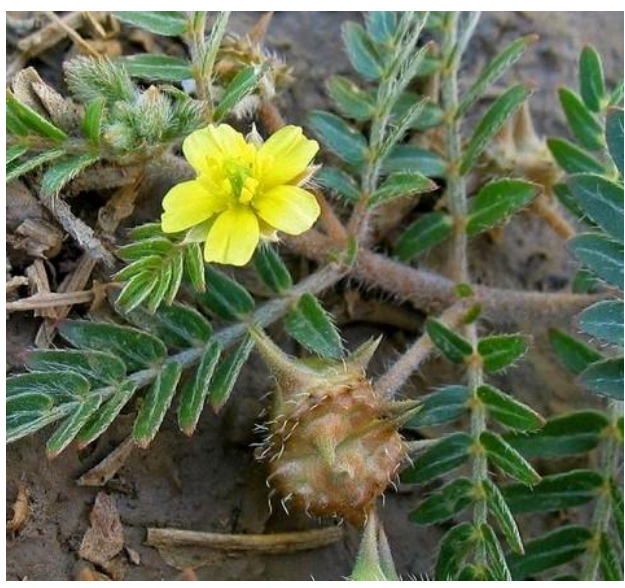

Якорцы стелющиеся (https://blog-travushka.ru)

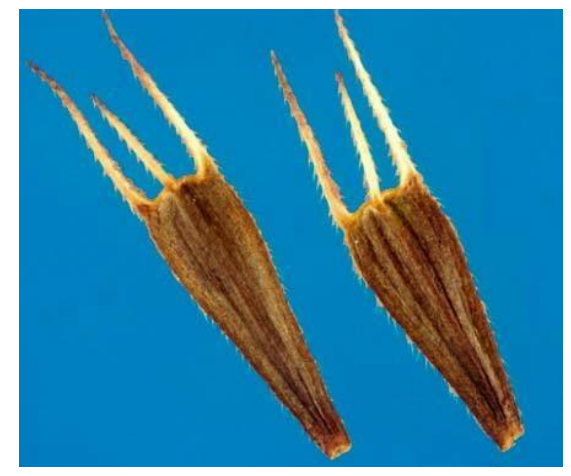

Плоды череды трёхраздельной (http://www.agroflora.ru)

По-видимому, единственным в крае древесным эпизоохором является линнея северная (семейство Жимолостевые), имеющая парные ягодообразные, почти сухие односемянные плоды с плотно прилегающими к ним прицветниками, усаженными клейкими железками, благодаря которым они прикрепляются к шерсти животных.

Как обычно, отличились тропические растения. Плоды пизонии из семейства Никтагиновые, распространённой на островах Тихого океана, настолько клейкие, что иногда густо облепляют тело птиц, которые теряют возможность двигаться и погибают.

Однако растений с клейкими диаспорами в целом немного. Гораздо более распространены различные морфологические приспособления, помогающие прикрепиться к шерсти или перьями - в виде шипов, крючков и др.

У некоторых пастбищных растений имеются плоды, снабженные острыми крепкими шипами, которые вонзаются в подошвы ног и копыта животных. Примером таких растений могут служить якорцы стелющиеся из семейства Парнолистниковые. Это широко распространённое тропическое растение в 1988 году было обнаружено Т.И. Нечаевой в окрестностях Владивостока. Плоды якорцов снабжены двумя-четырьмя шипами.

Большинство же растений для прикрепления использует так называемые прицепки, свойственные плодам или, реже, соплодиям. У ряда растений они могут быть прямыми, как у череды трёхраздельной из семейства Астровые. 


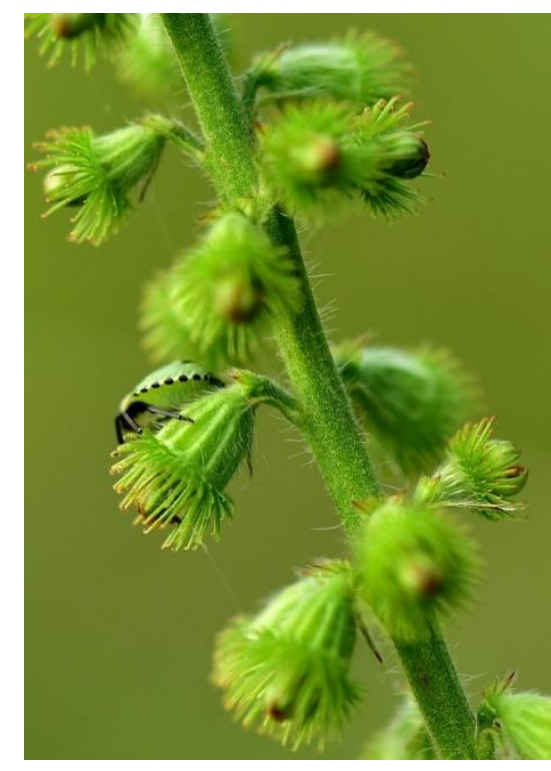

Плоды репяшка (http://mycoweb.ru)
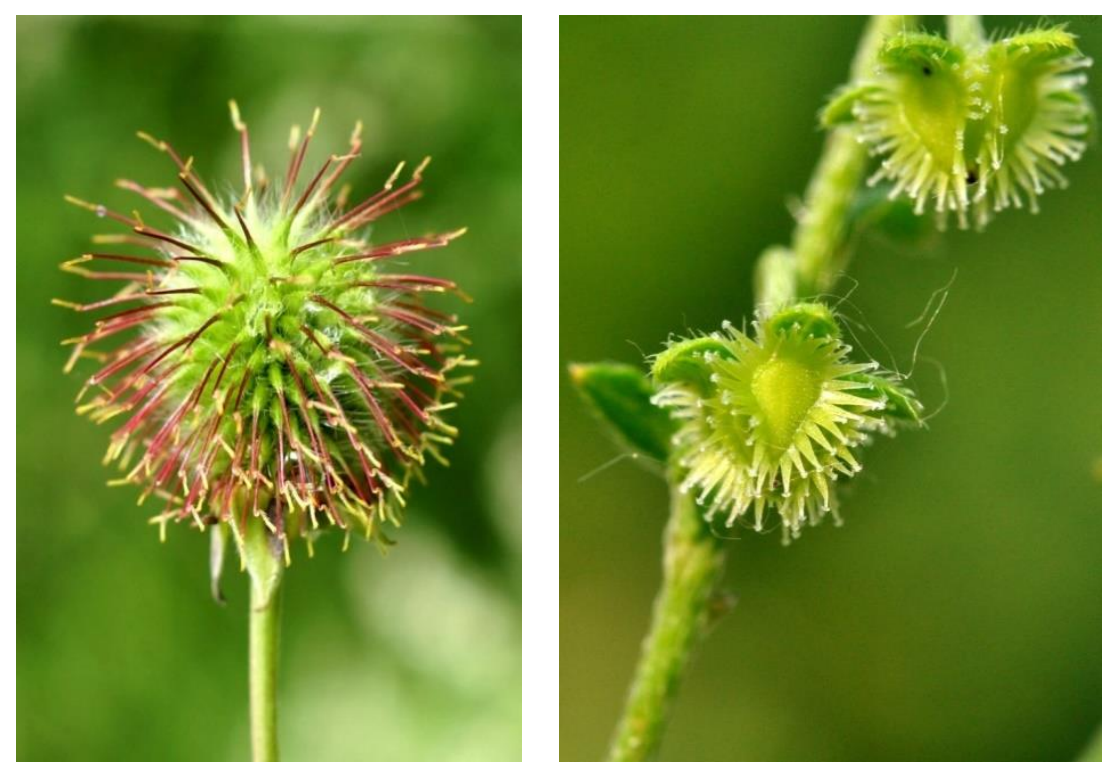

Плод гравилата алеппского (https://www.plantarium.ru)
Плод гакелии повислоплодной (https://www.plantarium.ru)

Но у большинства имеются крючковидные прицепки. Наиболее известны такие растения из семейств Розовые и Астровые. Например, в Приморье произрастают четыре вида репяшка из семейства Розовые. Это довольно крупные травы, встречаемые как в лесах, так и у человеческого жилья, в частности, в городах. Семянки репяшков в верхней части имеют небольшие крючковидные выросты, являющиеся видоизмёненными столбиками. Ещё один представитель этого семейства - гравилат - имеет плод многоорешек, в котором каждый орешек снабжен длинным видоизменённым столбиком, загнутым на конце. Само соплодие широкоовальное и легко цепляется (либо выхватываются отдельные плоды). У растений рода подмаренник (семейство Мареновые) плоды покрыты многочисленными крючковидными щетинками.

Плоды (орешки) липучки растопыренной из семейства Бурачниковые, растущей на полях, сухих степных склонах возвышенностей по югу Приморья, снабжены многочисленными якорными эмергенцами до 1,5 мм длины. Эмергенцы на плодах имеют и другие представители семейства - гакелия повислоплодная, незабудочник седой.

Есть растения, расселяющиеся только соплодиями - это дурнишник и лопух. У дурнишника, который все знают по колючим цепким зелёным «шишечкам», представляющим обертки и заключающие по две семянки, имеет некоторое число крючковидных выростов до двух с половиной миллиметров длины, а на верхушке - еще два шиловидных выроста «клювика». В Приморье произрастают пять видов дурнишника - игольчатый, сибирский, зобовидный, калифорнийский и эльбский.

А вот у лопуха (лопушника, репейника) сами листочки обертки заканчиваются крючками, весьма острыми, они могут прицепиться не только к одежде, но и к ладони. В Приморье произрастают три вида этого рода - лопухи большой (или репейник), войлочный и малый.

Конечно, растения с такими плодами встречаются не только в Приморском крае. Плоды гарпагофитума из семейства Кунжутовые, или растения-гарпуна, имеют длинные выросты, снабженные на конце крючками, которые настолько остры, что если взять его в руки настолько сильно впиваются в них, что освободиться бывает очень сложно. Интересно, что 
крестьяне Мадагаскара, где обитает это растение, используют его в качестве мышеловки: в середину кучи из плодов гарпагофитума они помещают приманку, и мышь (либо крыса) уже не может выбраться из нее.

Весьма впечатляющий способ расселения избрали виды пробосцидеи (семейство Мартиниевые) из США: их довольно крупные, до 28 см, коробочки имеют длинные загнутые выросты, напоминающие изогнутые бивни мамонта. По созревании семян коробочки цепляются этими выростами, как челюстями, (одно из местных названий растения - «челюсти дьявола») за лапы проходящих животных, и таким образом разносятся.

Этот секрет растений - прикрепляться с помощью крючков - в 1951 году подсмотрел швейцарский инженер Джордж де Местраль. Он любил охоту и часто гулял со своей собакой. Однажды, возвращаясь домой, он заметил, что к её шерсти и к его брюкам прилипли соплодия чертополоха. Устав постоянно чистить собаку, инженер решил выяснить причину, по которой сорняки прилипают к шерсти. Применив микроскоп, де Местраль понял, что она заключается в наличии маленьких крючков, которые цепляются за волосы и волокна ткани. В результате через восемь лет (в 1959 году) он запатентовал удобную застежку - «липучку» Velcro (от французского velours - петля и crochet - крючок), которая и сегодня широко используется при изготовлении одежды и обуви.

Все рассмотренные пути эпизоохории страдают одним недостатком - растению приходится ждать, когда животное соизволит приблизиться к нему, чтобы состоялся долгожданный «контакт».

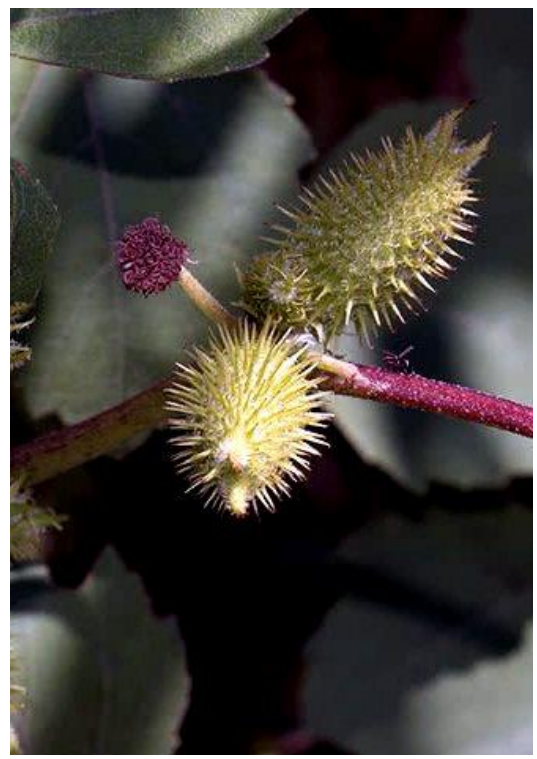

Плоды дурнишника (https://images.floristics.info)

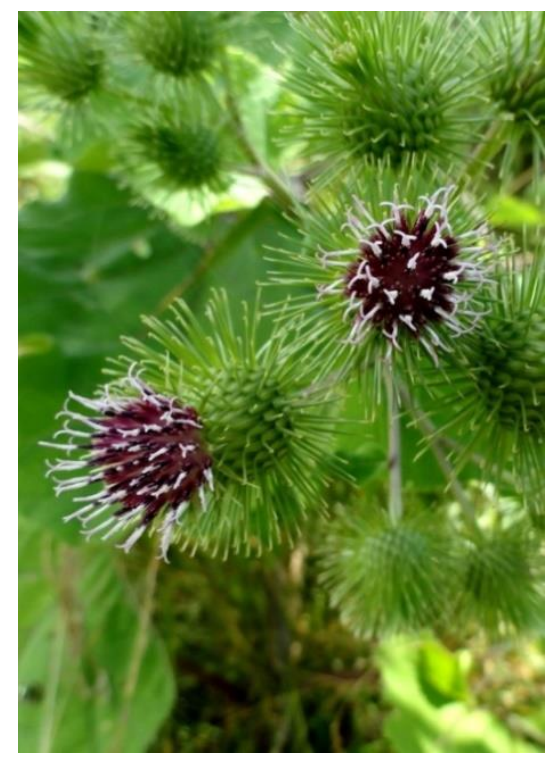

Репейник

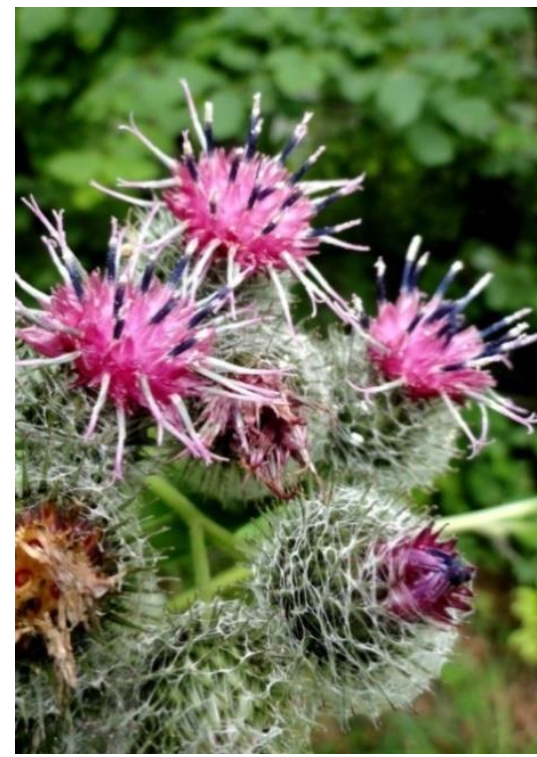

Лопух войлочный

Поэтому многие представители растительного царства, дабы сократить ожидание, решили приманить животных угощением. Для этого они накопили в околоплоднике разные вкусности, прежде всего сладкие углеводы. Рассчитали они правильно - съев плод, животное (или птица) прежде чем избавиться от неперевариваемой его части (для этого растения заключили семя в плотную деревянистую ткань, «создав», например, косточку), пройдет (пролетит) какое-то расстояние. Вот и будет достигнута цель расселения.

Такой способ получил название эндозоохории. 
В Приморье основными распространителями плодов и семян древесных растений являются птицы. В своём большинстве они переходят на растительную пищу осенью, когда животной пищи уже недостаточно. Всего на территории края зарегистрировано более 400 видов пролетных и гнездящихся птиц. Понятно, что не все из них используют в своём рационе растительные корма, а если используют, то не все являются распространителями диаспор. Так, среди птиц лесных формаций плоды и семена более чем 100 видов растений поедают около 75 видов птиц.

Распространение диаспор растений птицами получило название орнитохории, а растения, «использующие» птиц, называются орнитохорами. Плоды орнитохоров как правило имеют яркую и контрастную окраску, лишены запаха - всё в соответствии с острым зрением пернатых и их слабым обонянием. Да и созревают плоды осенью, когда птицы переходят с животной диеты на растительную.

Степень использования птицами растительной пищи (а отсюда и успешность расселения плодов и семян) связана как с морфологическими особенностями самих диаспор, так и степенью их повреждения (клювом и в пищеварительном канале). Исходя из этих критериев, дальневосточный орнитолог В.А. Нечаев выделил несколько групп птиц, участвующих в распространении диаспор.

В первую группу входят птицы, полностью или частично разрушающие клювами твёрдые и мягкие оболочки диаспор, а диаспоры небольших размеров проглатывающие целиком. При этом мелкие семена не перевариваются и выбрасываются с экскрементами. Среди таких птиц черный журавль, седой дятел, большой пестрый дятел, пищуха, полевой воробей и другие.

Вторая группа включает птиц, заглатывающих сочные диаспоры целиком, не повреждая их. Семена впоследствии выбрасываются с экскрементами или в виде погадок (непереваренных остатков пищи, отрыгиваемых птицами). Это такие птицы, как черноголовая иволга, серый скворец, кукша, сорока, голубая сорока, черная ворона и многие другие.

Еще одну группу составляют птицы (горлицы, например, или рябчики, фазаны), которые часть плодов перетирают камешками (гастролитами), находящимися в желудке.

Любопытным примером является расселение омелы окрашенной из одноименного семейства. Омела - полупаразитический эпифит, произрастающий на ветвях и стволах различных древесных растений. Основным распространителем омелы окрашенной является свиристель - эта птица питается омелой в зимнее время. Коэффицент усваивания при этом весьма небольшой, плоды легко и достаточно быстро (от заглатывания до выделения помета проходит лишь 20 минут) проходят через пищеварительный тракт, значительно не повреждаясь. Липкий сок плодов способствует тому, что при их высвобождении смесь плодов с клейким соком в виде длинных тяжей птица некоторое время носит с собой. Стараясь освободиться от них, она усиленно трется подхвостьем о кору. Прилипшие к ней семена впоследствии прорастают, если иммунитет дерева ослаблен.

Остальные виды птиц являются пассивными агентами зоохории, роняя неповрежденные диаспоры на почву в местах кормежки. Так, самцы гаички уносят в клюве ягоды жимолости раннецветущей (семейство Жимолостевые). Зажав плод лапками, птица извлекает семена; при этом часто она его роняет и летит за новым (если плодов много, обычно птица не подбирает упавший). Малый острокрылый дятел, поедая семена аралии высокой (семейство Аралиевые), часть роняет тут же на месте, а часть - на некотором расстоянии от растения. Так же поступает большая синица.

Млекопитающие в качестве эндозоохоров выступают значительно реже. Ведущая роль при этом также принадлежит хищникам. Так, медведи гималайский и бурый охотно по- 
едают плоды актинидии коломикта и особенно черёмухи Маака, способствуя дальнейшему их распространению. В то же время растительноядные млекопитающие либо перетирают семена зубами (лось, заяц) или потребляют только семена хвойных и лиственных видов, редко используя мякоть плодов (бурундук).

Наконец, существует и третий путь зоохории, при котором диаспоры запасаются животными, но часть их теряется при переносе в кладовые, либо забывается местоположение кладовых. Любопытно, что человек решил воспользоваться запасливостью зверей и иногда использовал содержимое их кладовых для добычи хороших (а плохие животные запасать не станут!) семян и плодов для своих хозяйственных целей. Так, в России, в Воронежской губернии в 19 веке осенью «грабили мышь»: отыскивали норы мышевидных грызунов и извлекали оттуда запасы орехов. На Камчатке, по свидетельству С.П. Крашенинникова, аборигены обследовали кладовые полёвок-экономок в поисках кореньев и семян кедрового стланика.

Собственно синзоохорными растениями являются растения с сухими плодами или с плодами с засыхающим в зрелости и раскрывающимся мезокарпом, а также с семенами с сухой или очень прочной семенной кожурой. В Приморье к синзоохорным растениям можно отнести виды сосны, лещины, дуба.

В наибольшей степени изучено распространение животными диаспор сосны корейской, или кедра (семейство Сосновые). В 1958-1965 годах в Приморском крае сотрудники Биолого-почвенного института ДВФ СО АН СССР изучали трофические связи лесных птиц и млекопитающих Среднего и Южного Сихотэ-Алиня с сосной корейской (кедром). Было выяснено, что семена кедра поедаются (и запасаются) 33 видами птиц и млекопитающих. Считалось, что в расселении кедра принимают участие кедровка, белка, кабан, медведь, бурундук.

Однако последующие исследования показали, что наиболее тесно с кедром и образуемыми им сообществами связаны кедровка и поползень. Эти виды являются узкоспециализированными консументами, в пище которых семена кедра преобладают большую часть года. Они делают запасы семян, укрывая их в лесной подстилке, на поверхности почвы, заделывая в щели стволов деревьев, а кедровка выкармливает ими своих птенцов. Наибольшая плотность их населения приурочена именно к кедровникам. Значение поползня особенно велико в лесах, где кедр сохранился фрагментарно и не обеспечивает стабильное питание кедровкам. В урожайные годы поползень создает значительные запасы семян кедра, используемых и в выкармливании птенцов. Эти птицы уносят семена и в прилегающие к кедровникам широколиственные леса. Значение кедровки возрастает в кедрово-широколиственных лесах.

Кедровка и поползень являются важнейшими зоохорами сосны корейской. Другие животные, питающиеся семенами кедра - черноголовый дубонос, дятлы, большеклювая ворона, азиатская лесная мышь, барсук, лисица, енотовидная собака, медведь - практически не содействуют его расселению; это же относится и к самосеву. Возобновление этого растения целиком приписывают кедровке и поползню. Благодаря им в кедрово-широколиственных лесах Сихотэ-Алиня, по оценкам учёных, 10,7-52,3 тыс. семян кедра (6-29,5 кг на 1 га) оказываются укрытыми под подстилкой или в верхнем слое почвы.

Расселению сосны корейской могут способствовать белка и бурундук. Семена сосны белки прячут недалеко от материнского дерева, либо уносят на удаленные участки в шишках, очищенных от семенных чешуй. Создавать кладки они начинают в первой половине сентября, когда шишки ещё висят на деревьях. Белка подгрызает их, шишки падают на почву, где животное очищает их от чешуй. Затем на некотором расстоянии белка вынимает 2-4 семени и прячет их в подстилку либо неглубоко в почву. В годы больших урожаев белки часто не используют свои запасы, предпочитая добывать их из шишек на растениях. 
Кладовые бурундуков содержат по 5-8 семян сосны корейской, и если кладки не используются, то в этих местах появляются групповые всходы. Как правило, кладки располагаются недалеко от материнского дерева, в нескольких десятках метров, и лишь редко за 100-200 м.

Семена сосны корейской активно заносятся кедровками и поползнями на свежие гари, особенно в первые два года после пожара, когда отсутствует задернение и травяной покров.

Сойка может запасать плоды ореха маньчжурского (семейство Ореховые), лещины маньчжурской (семейство Берёзовые), липы Таке (семейство Липовые) и других растений, но наиболее важную роль она играет в распространении плодов дуба монгольского (семейство Буковые). Клюв и лапы этой птицы хорошо приспособлены к использованию желудей.

Из млекопитающих синзоохорами главным образом являются грызуны. Бурундук делает запасы из семян сосны корейской, плодов черёмухи Маака, вишни Максимовича (семейство Розовые), лимонника китайского (семейство Лимонниковые), дуба монгольского, видов клена, липы. Его кладовые обычно располагаются под выворотами деревьев или в основании корней на глубине 20-30 см и более, при которой семена прорасти не могут. Возможность прорастания создается лишь в случае потери какой-то их части при заготовках или расхищении кладовых медведями, кабаном и другими млекопитающими.

Из мышевидных грызунов в распространении диаспор участвуют полёвки и лесные мыши. Красно-серая полёвка при сборе семян лазает по деревьям, кустарникам и стеблям трав. Её запасы хранятся в случайных местах - под корнями деревьев, в щелях пней, под корой, в почве и т.д.

На свежих гарях довольно важную роль в расселении некоторых растений играют грызуны. Так, на двулетних гарях часто встречаются группы всходов клёна зеленокорого, появившиеся из запасенных грызунами семян.

Белки запасают на зиму орехи лещины маньчжурской и лещины разнолистной, ореха маньчжурского, семена сосны корейской, желуди дуба монгольского, закапывая их в подстилку или почву.

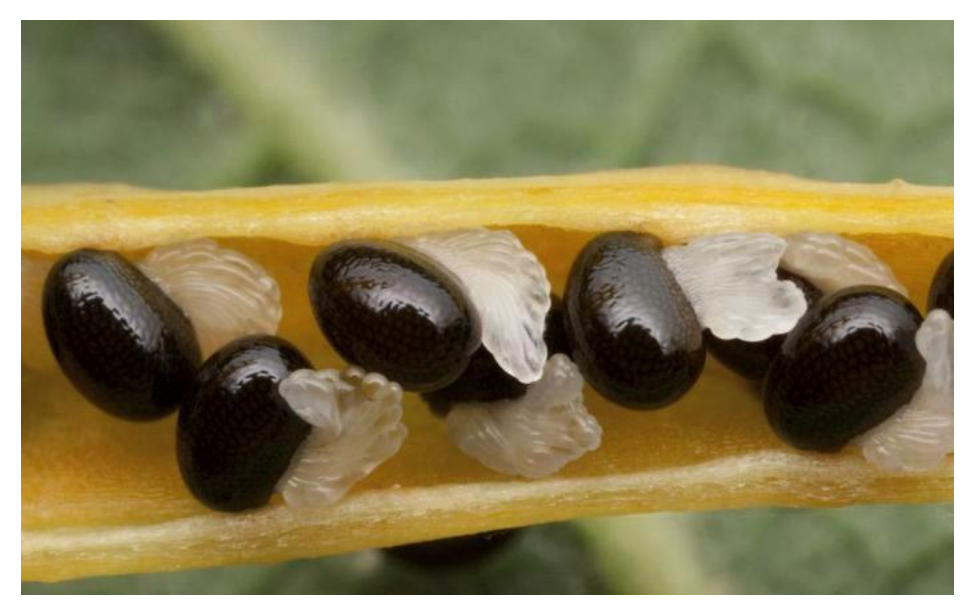

Семена чистотела (http://antclub.org)

Особый случай синзоохории представляет мирмекохория - расселение растений с помощью муравьев. Муравьи делают значительные запасы семян, используя их впоследствии в пищу. Запасаются лишь семена, имеющие так называемые придатки - ариллусы (они содержат масла, углеводы, белки, что и привлекает к ним муравьев). Мирмекохоры имеются в семействах Маковые (чистотел, лесной мак, хохлатка и др.), Фиалковые (различные виды фи- 
алки), Кислицевые (кислицы обыкновенная и обратнотреугольная), Кирказоновые (копытень Зибольда), Ситниковые (виды ожики) и др. Семена чистотела уносятся муравьями на расстояние до 3 м, кислицы - до 2,5 м. Впоследствии, после употребления присемянников, эти семена выбрасываются из гнезд и прорастают на разном удалении от материнского растения.

Семена ряда видов (погремка, одуванчика, лиственницы) муравьи используют для строительства гнёзд, но часть их теряют по дороге.

\section{Широко распространённые и эндемичные растения Приморья}

В Приморском крае произрастают более двух тысяч видов высших растений. Одни из них можно встретить почти в каждом уголке края, другие очень редки и произрастают лишь в определенных местах Приморья.

Среди широко распространённых видов есть представители т.н. космополитов, т.е. растений, ареал которых охватывает большую часть планеты. При этом у одних из них этот ареал является естественным, у других создан с помощью человека. В Приморье растениякосмополиты также встречаются более или менее широко, обычно кроме горных районов.

Так, по всему краю, как правило, на открытых местах (у дорог, на прибрежных песках, в населённых пунктах) произрастает подорожник большой из одноимённого семейства. Этот розеточный многолетник является известным лекарственным растением. А всего в Приморье произрастают около десяти видов подорожника.

Семейство Капустовые в Приморье представлено таким космополитом, как пастушья сумка обыкновенная. Она есть во всех частях света кроме тропиков. Как сорное, это растение обычно на полях и огородах, в населённых пунктах.

Много в Приморье космополитов из семейства Мятликовые (Злаки). Это мятлик луговой, произрастающий по опушкам, влажным лугам, у дорог; тростник южный (или обыкновенный), растущий на влажных болотистых лугах и по берегам водоёмов; лисохвост равный этот небольшой однолетник или двулетник встречается на влажных лугах, по канавам, у дорог.

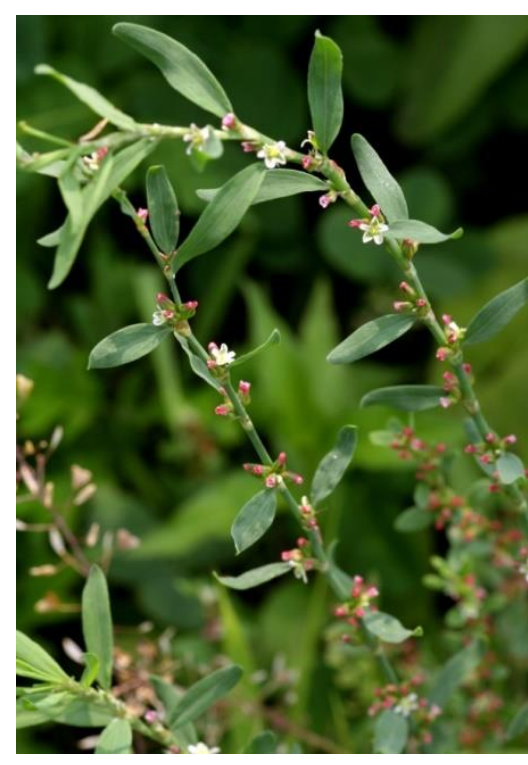

Спорыш птичий (https://www.wikipedia.org)

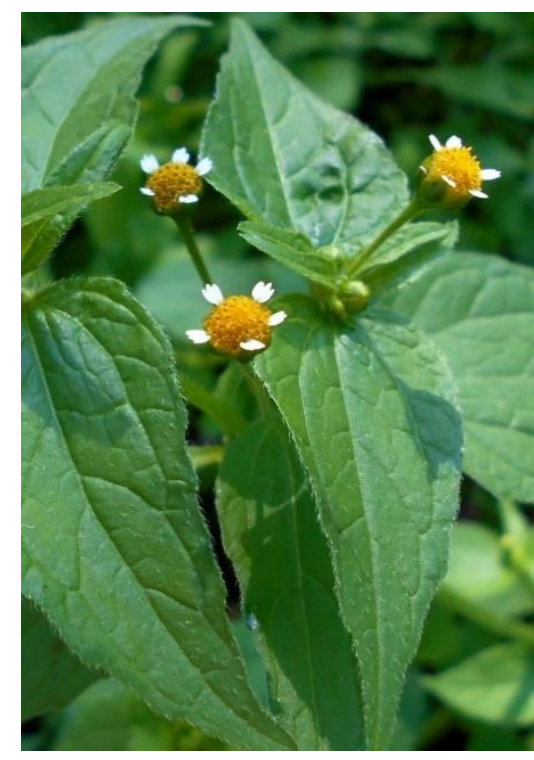

Галинсога мелкоцветковая (http://lisky.org.ua)

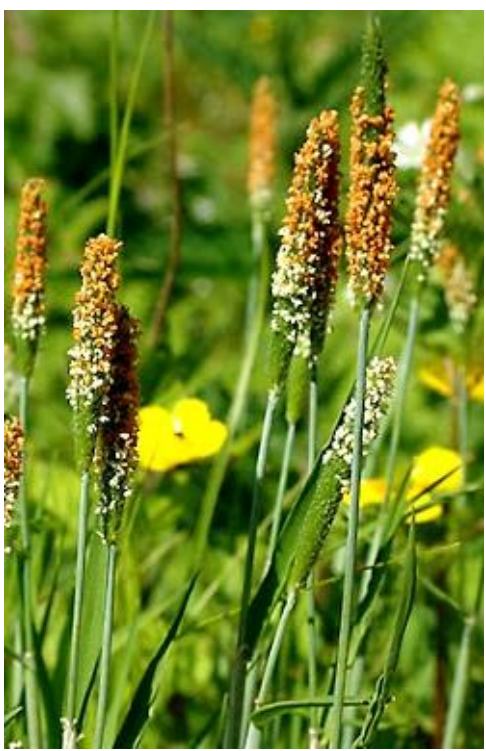

Лисохвост равный (http://florapedia.ru) 
Спорыш птичий (горец птичий) из семейства Гречиховые растёт как сорное у дорог и тропинок, на полях, в населённых пунктах.

Семейство Астровые (Сложноцветные) в Приморье представлено такими космополитами, как галинсога мелкоцветковая и одуванчик лекарственный. Галинсога, родина которой Южная Америка, человеком занесена почти во все районы мира. В Приморье она растёт в обжитых районах - как сорное на огородах и полях, в населённых пунктах. Преимущественно в населённых пунктах, а также на засорённых лугах растёт одуванчик лекарственный, применяемый в официальной и народной медицине.

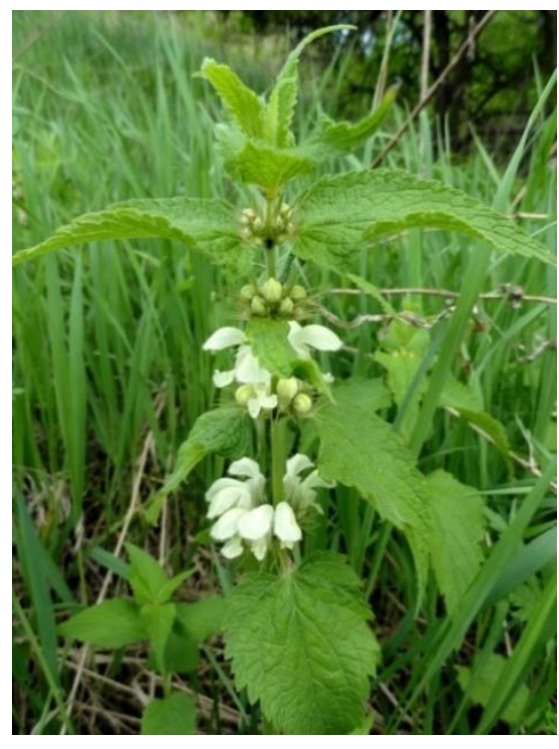

Яснотка бородчатая

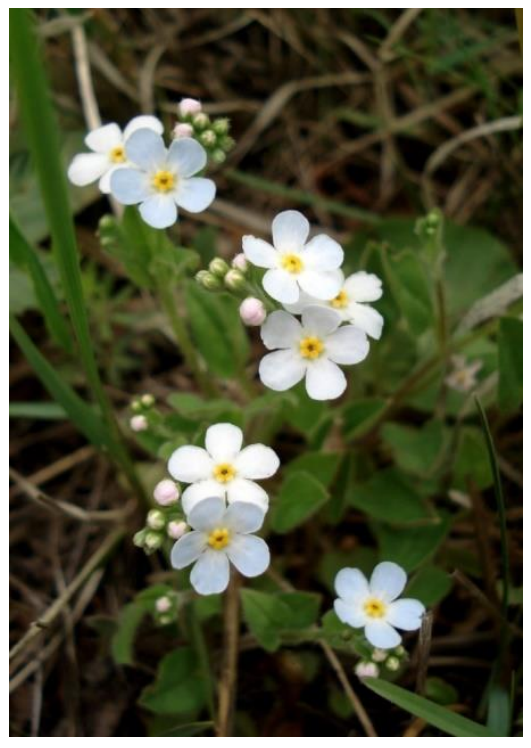

Тригонотис укореняющийся

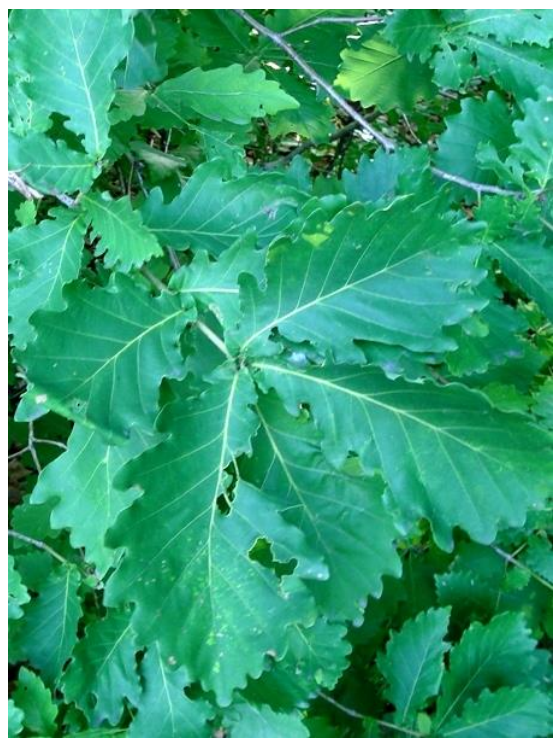

Дуб монгольский

Не являются космополитами, но в крае широко распространены такие виды, как мерингия бокоцветная и смолёвка ползучая (семейство Гвоздиковые), яснотка бородатая (семейство Яснотковые), калужница болотная и виды василисников (семейство Лютиковые), лилии двурядная и пенсильванская (семейство Лилиевые), подмаренник даурский (семейство Мареновые), тригонотис укореняющийся (семейство Бурачниковые), астры тарарская и Маака (семейство Астровые) и еще целый ряд других видов.

Одним из самых распространённых в Приморье древесным растением является дуб монгольский. Леса с его участием (дубняки различных типов) занимают более $16 \%$ площади лесов края. Среди них преобладают дубняки, в которых в подлеске встречаются кустарники леспедеца двуцветная (семейство Бобовые) и два вида лещины - маньчжурская и разнолистная. Эти кустарники также являются одними из самых распространённых в крае. Из других кустарников, часто встречающихся в Приморье, можно назвать калину Саржента (семейство Жимолостевые), бузину сибирскую (кистистую) (семейство Бузиновые), берёзу овальнолистную (семейство Берёзовые).

Широко распространены в крае такие деревья, как берёзы плосколистная и даурская (семейство Берёзовые), орех маньчжурский (семейство Ореховые), липа амурская (семейство Липовые), черёмуха обыкновенная (семейство Розовые), клёны мелколистный и приречный (семейство Клёновые). Клён яснелистный, или негундо (родина Северная Америка), встречается в озеленении многих населённых пунктов Приморья, часто дичает и проявляет потенциальные инвазивные свойства. 


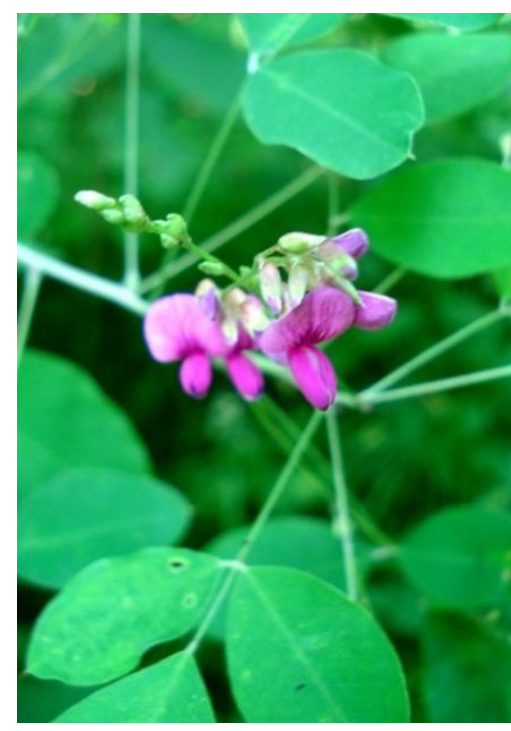

Леспедеца двуцветная

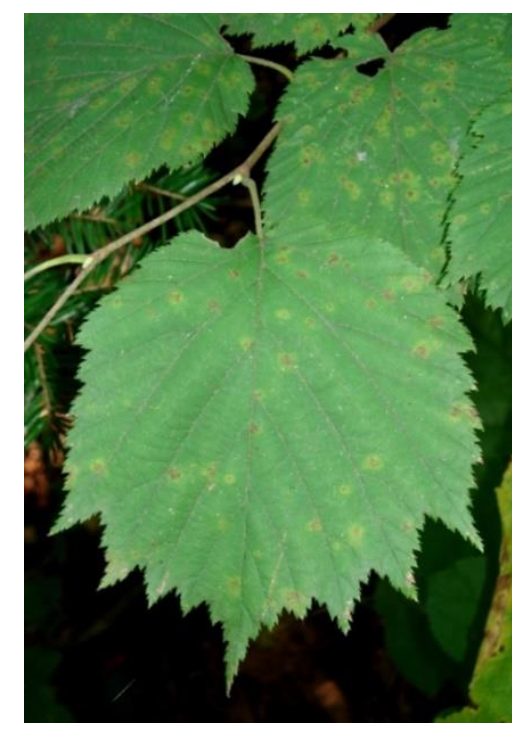

Лещина разнолистная

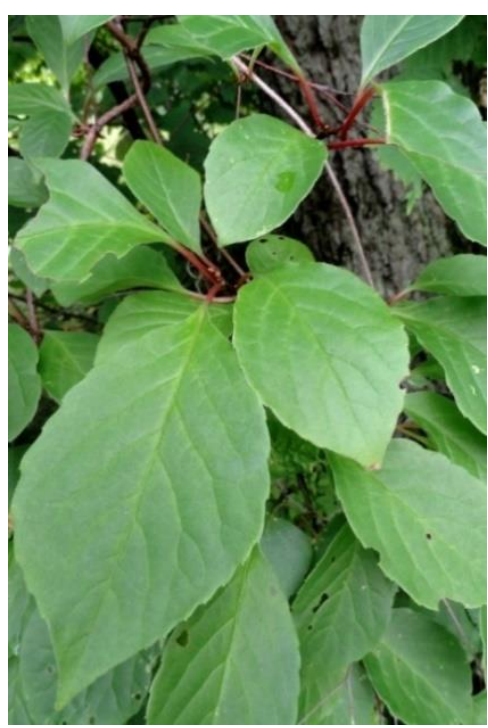

Лимонник китайский

Наконец, в крае широко распространены древовидная лиана виноград амурский (семейство Виноградовые), кустарниковая лиана лимонник китайский (семейство Лимонниковые), полукустарниковая лиана луносемянник даурский (семейство Луносемянниковые), у которого к зиме почти вся надземная часть отмирает и лишь несколько сантиметров стебля остаются живыми. Правда, в культуре, а луносемянник иногда используется в вертикальном озеленении, размеры неотмирающей части больше - до полуметра.

Но есть в Приморье и растения, распространение и численность которых весьма ограничены. Всего в крае насчитывают 259 видов редких и исчезающих высших растений, из которых 45 видов мхов, 1 вид плаунов (полушник азиатский), 22 вида папоротников, 6 видов голосеменных и 185 видов покрытосеменных растений. Большая их часть находится под защитой в заповедниках и других особо охраняемых природных территориях. Некоторые растения из этого списка культивируются в дендрарии Горнотаежной станции и в Ботаническом саду-институте Дальневосточного отделения Российской Академии наук (ДВО РАН), где исследуется их биология и возможность искусственного размножения.

Важнейшая задача, стоящая сегодня перед приморскими учёными - организовать изучение и охрану растений, не встречающихся в охраняемых территориях и поэтому практически не защищённых. Это такие виды, как кровохлебка великолепная (семейство Розовые), виноградовник японский (семейство Виноградовые), кирказон маньчжурский (семейство Кирказоновые), беламканда китайская (семейство Касатиковые) и некоторые другие.

Степень редкости растений, которая определяется в Красной книге Приморского края, различна. Так, статус «исчезнувшие» (виды, сборы которых производились достаточно давно, но с той поры растения не встречались) имеет жимолость одноцветковая (семейство Жимолостевые).

Гораздо больше растений из группы «на грани исчезновения». Их очень мало, и высока вероятность того, что без охраны они исчезнут. Всего насчитывается 27 видов этой группы, они относятся к семействам Фиалковые (фиалки хасанская, надрезанная и диамантская), Частуховые (кальдезия почковидная), Крыжовниковые (смородина уссурийская), Капустовые (мегадения пещерная) и др.

Еще больше растений со статусами «угрожаемые» и «уязвимые». Из первых можно упомянуть представителей кирказоновых (кирказон маньчжурский), кабомбовых (бразения 
Шребера), яснотковых (тимьян Пржевальского), из вторых - виды бобовых (пуерария лопастная, клевер Гордеева), маковых (мак аномальный), розовых (струноплодник пильчатолистный).

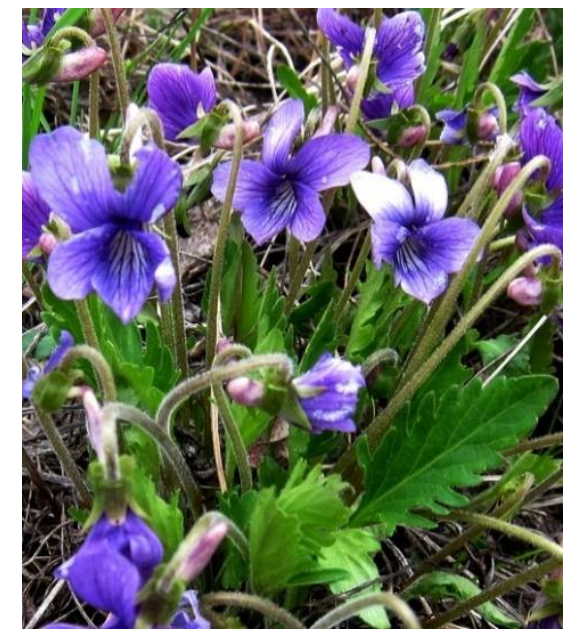

Фиалка надрезанная

(https://www.plantarium.ru)

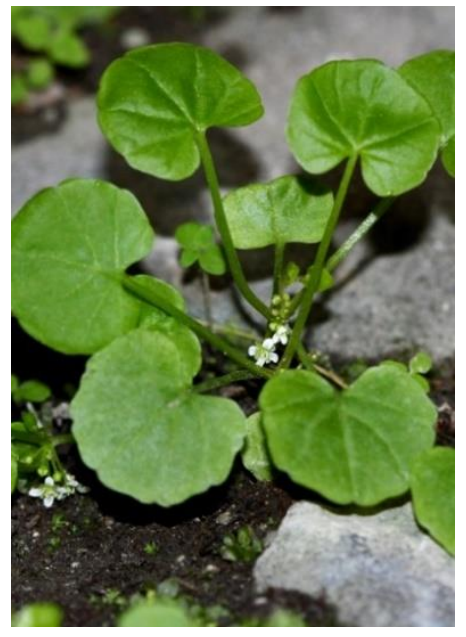

Мегадения пещерная (https://www.plantarium.ru)

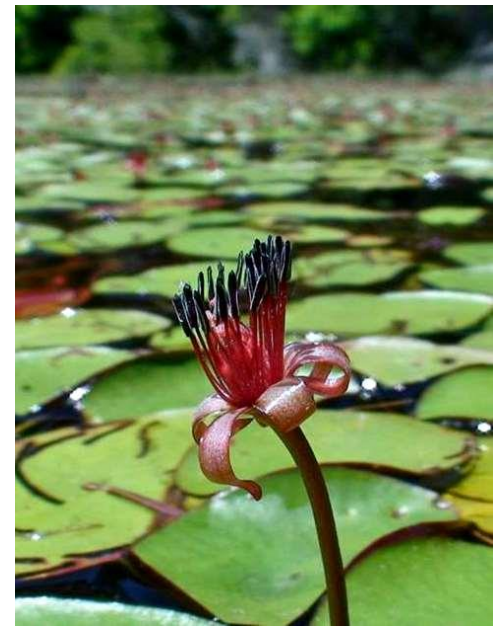

Бразения Шребера (https://leplants.ru)

В некоторых случаях в группу редких растений относят и такие виды, которые встречаются еще в достаточном количестве, но их численность сокращается вследствие негативного воздействия со стороны человека (прямого, как, например, сборы на лекарственное сырье, букеты, и опосредованного, через изменение привычных условий обитания) и могут также стать редкими. Это груша уссурийская (семейство Розовые), диоскорея ниппонская (семейство Диоскореевые), рябчик уссурийский (семейство Лилиевые), тис остроконечный (семейство Тисовые), сирень Вольфа (семейство Маслиновые) и некоторые другие растения. А интенсивные сборы женьшеня привели к почти полному его исчезновению из наших лесов.

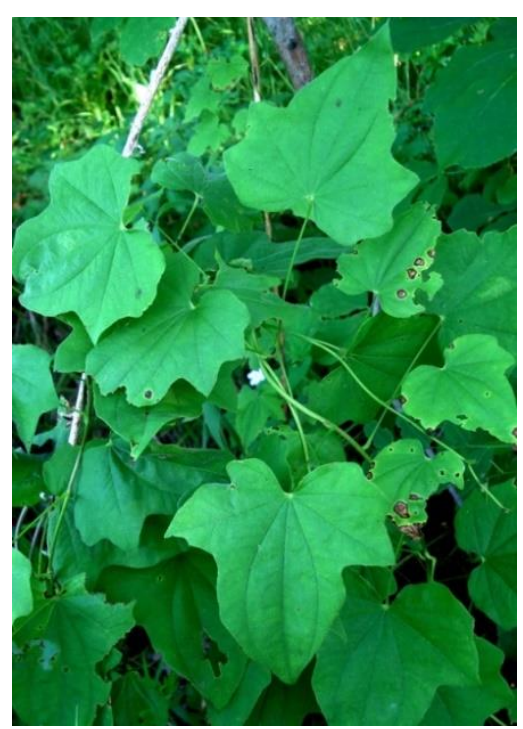

Диоскорея ниппонская

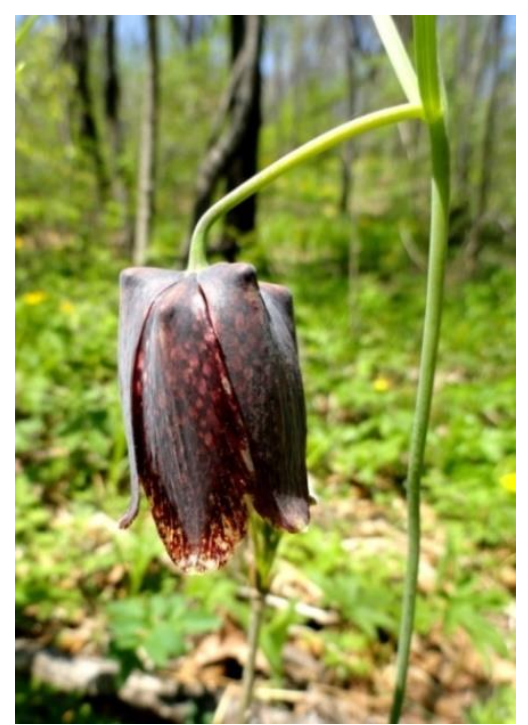

Рябчик уссурийкий

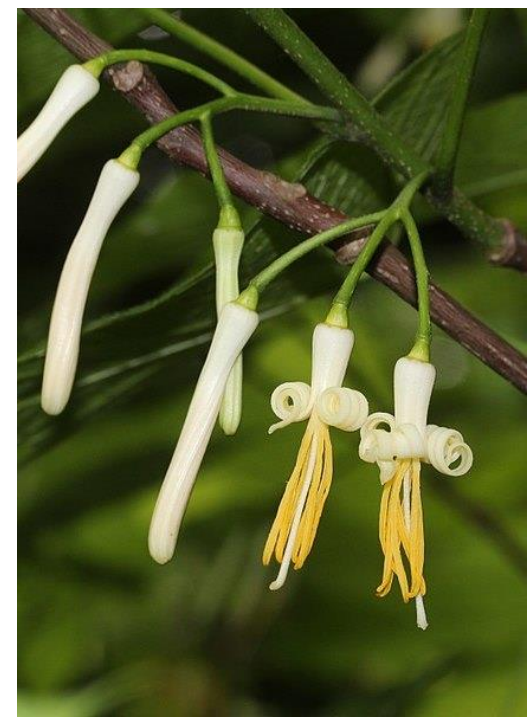

Алангиум платанолистный (https://all-begoniastamaravn.blogspot.com) 
В последнее время описан ряд видов, которые известны лишь из нескольких точек в Приморье и поэтому также достойны войти в региональную Красную книгу. Это, например, алангиум платанолистный (семейство Алангиевые), довольно крупный, до 3 м высоты, оригинальный кустарник, который был обнаружен в 2001 г. в Надеждинском районе, в бассейне р. Перевозной.

Причины редкости растений различны. Чаще всего редкие виды произрастают на территории соседних стран (Китая, Японии, Северной Кореи) и соседних регионов Дальнего Востока заходя «краешком» своего ареала и в Приморье. Из растений, включенных в Красную книгу Приморского края, к этой группе относятся женьшень настоящий (семейство Аралиевые), дуб зубчатый (семейство Буковые), тис остроконечный (семейство Тисовые), лотос Комарова (семейство Лотосовые), солодка бледноцветковая (семейство Бобовые) и много других видов.

Реже редкость обусловлена небольшим ареалом, и тогда растения можно считать дальневосточными или приморскими эндемиками.

Примером первых является микробиота перекрестнопарная (семейство Кипарисовые), произрастающая по высокогорьям хребта Сихотэ-Алинь (Приморский и Хабаровский края) и нигде более не встречающаяся. Только на Сихотэ-Алине растут также бадан тихоокеанский из семейства Камнеломковые, рябинник сумахолистный из семейства Розовые. Поповиокодония узкоплодная (семейство Колокольчиковые) произрастает в Приморье, Хабаровском крае и на Сахалине. На приморских скалах и галечниках Приморья и Хабаровского края растёт горноколосник удивительный из семейства Толстянковые. В горных районах Приморья и Хабаровского края на мелкощебнистых осыпях растёт смеловския неожиданная из семейства Капустовые.

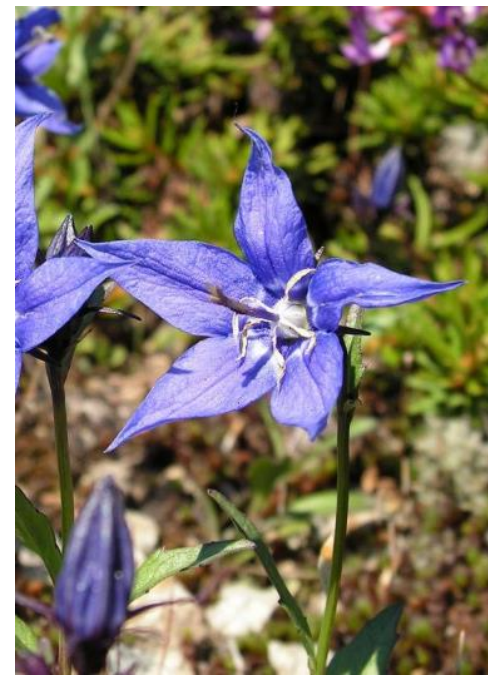

Поповиокодония узкоплодная

(https://www.plantarium.ru)

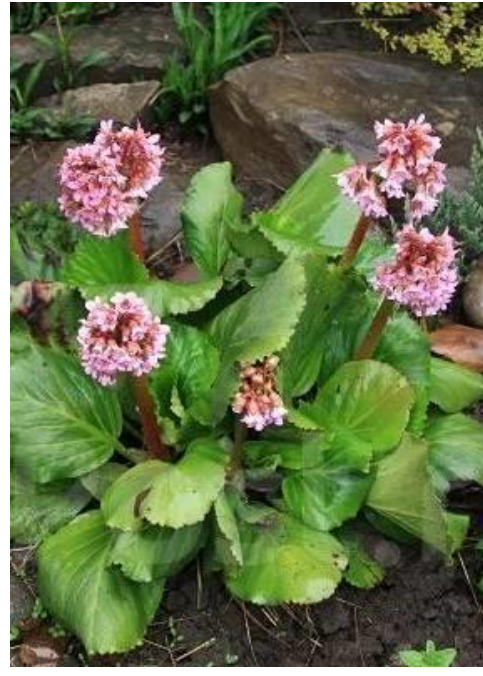

Бадан тихоокеанский (https://www.farpost.ru)

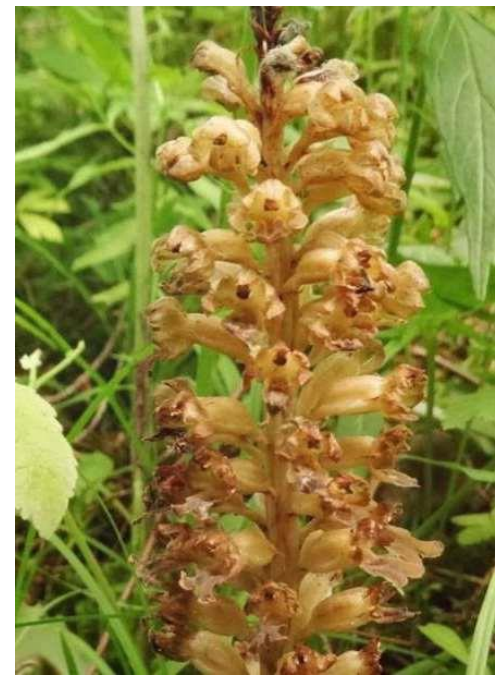

Гнездовка уссурийская (https://redbookrf.ru)

На территории Приморского края произрастают виды, которые нигде на Земле больше не встречаются. Во флору Приморского края входят около семнадцати эндемичных видов покрытосеменных растений.

Наибольшее число видов (четыре) приморских эндемиков относится к семейству Астровые. По два вида включают семейства Гвоздиковые, Бобовые и Розовые. Остальные семейства представлены одним видом. 


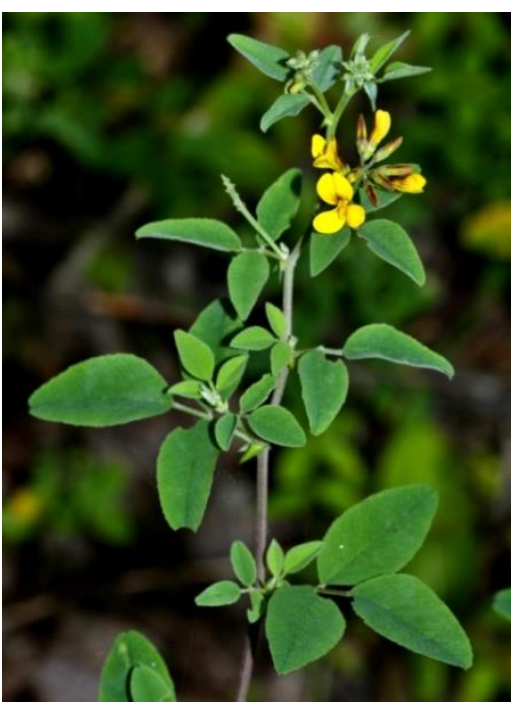

Мелилотоидес Шишкина (https://www.plantarium.ru)

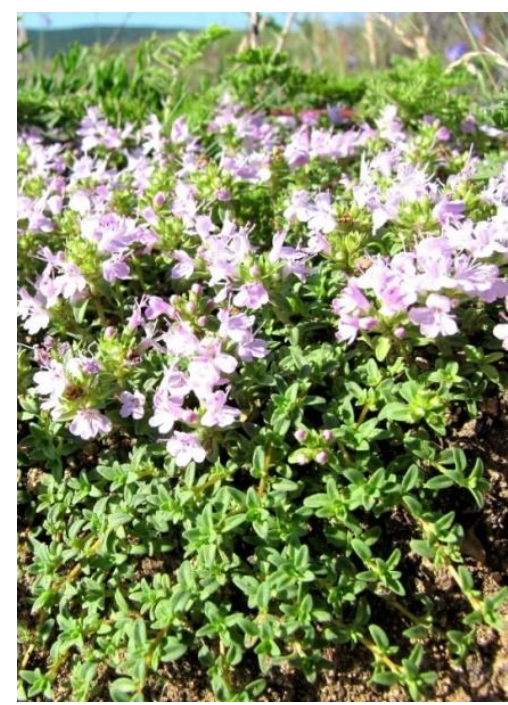

Тимьян тернейский (http://botsad.ru)

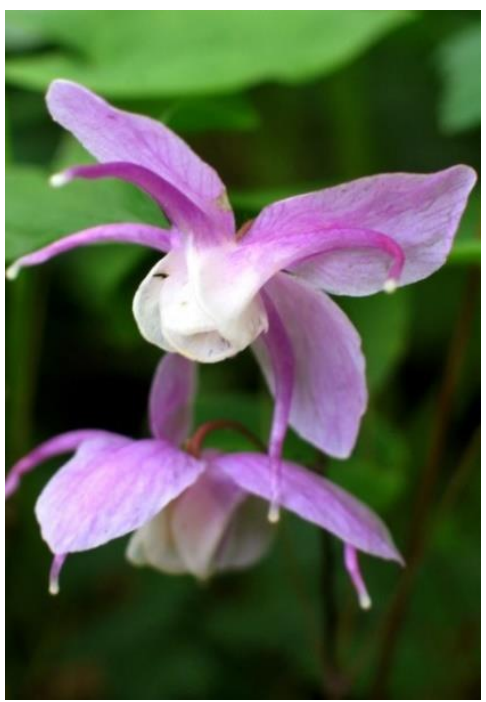

Горянка крупночашечковая (http://botsad.ru)

Если судить по географическому распространению эндемиков Приморья, преобладают растения, произрастающие в южной его части - 10 видов: бузульник Воробьёва, соссюрея Куренцовой (семейство Астровые), мегадения пещерная (семейство Капустовые), родиола Комарова (семейство Толстянковые), копеечник уссурийский (семейство Бобовые), волжанка малая, кровохлебка великолепная (семейство Розовые), шерстестебельник Десулави (семейство Шерстестебельниковые), гнездовка уссурийская (семейство Орхидные), димерия незамечаемая (семейство Мятликовые).

В центральном и южном Приморье встречается мелилотоидес Шишкина (семейство Бобовые).

Остальные эндемики произрастают в восточной части края, встречаясь главным образом по побережью, включая восточные предгорья Сихотэ-Алиня. Ряд из них произрастает в центральной части (представители гвоздиковых дрёма тёмная и минуарция стройная, тимьян тернейский из семейства Яснотковые и кортуза двуцветная из семейства Первоцветовые), некоторые - на юге (горянка крупночашечковая из семейства Барбарисовые), некоторые - в центре и на юге (соссюрея советская и эдельвейс Палибина из семейства Астровые).

Эндемики Приморья различаются не только своим распространением, но и занимаемыми местообитаниями. Так, тимьян тернейский из яснотковых растёт на песчаногалечниковых морских террасах, каменистые склоны и россыпи предпочитают соссюрея советская (семейство Астровые), дрёма тёмная (семейство Гвоздиковые), родиола Комарова (семейство Толстянковые). На болотистых лугах и болотах близ морского побережья растут шерстестебельник Десулави из одноимённого семейства и злак димерия незамечаемая.

Есть среди эндемиков Приморья и лесные растения - бузульник Воробьева, соссюрея Куренцовой (семейство Астровые), горянка крупночашечковая (семейство Брбарисовые), гнездовка уссурийская (семейство Орхидные).

Большая же часть видов тяготеет к известнякам: эдельвейс Палибина (семейство Астровые), мегадения пещерная (семейство Капустовые), минуарция стройная (семейство Гвоздиковые), мелилотоидес Шишкина (семейство Бобовые), кортуза двуцветная (семейство Первоцветовые), волжанка малая (семейство Розовые). А два вида являются облигатными кальцефилами: копеечник уссурийский (семейство Бобовые) и кровохлебка великолепная (семейство Розовые). 


\section{Используемая и рекомендуемая литература}

Безделев А.Б., Безделева Т.А. Жизненные формы семенных растений российского Дальнего Востока. Владивосток: Дальнаука. 2006. 296 с.

Буч Т.Г., Качура Н.Н., Швыдкая В.Д., Андреева Е.Р. Сорные растения Приморского края и меры борьбы с ними. Владивосток: Дальневосточное кн. Изд-во, 1981. 243 с.

Василюк В.К., Врищ Д.Л., Журавков А.Ф. и др. Озеленение городов Приморского края. Владивосток: ДВО АН СССР, 1987. 516 с.

Воробьев Д.П. Определитель весенних растений Приморья. Владивосток: Примиздат, 1949. $52 \mathrm{c}$.

Воробьев Д.П. Определитель деревьев и кустарников Приморья и Приамурья. Благовещенск: Амурское книжное изд-во, 1958. 184 с.

Воробьев Д.П. Дикорастущие деревья и кустарники Дальнего Востока. Л.: Наука, 1968. 277 c.

Воробьев Д.П. Определитель сосудистых растений окрестностей Владивостока. Л.: Наука, 1982. 253 с.

Воробьев Д.П., Ворошилов В.Н., Горовой П.Г., Шретер А.И. Определитель растений Приморья и Приамурья. Л.: Наука, 1966. 491 с.

Врищ Д.Л. Лилии Дальнего Востока и Сибири (ботанико-систематическое исследование). Владивосток: Дальневосточное кн. изд-во, 1972. $111 \mathrm{c.}$

Гончарова С.Б. Очитковые (Sedoideae, Crassulaceae) флоры российского Дальнего Востока. Владивосток: Дальнаука, 2006. 223 с.

Горовой П.Г. Зонтичные Приморья и Приамурья. М.;Л.: Наука, 1966. 296 с.

Гуков Г.В. Чье имя ты носишь, растение? Владивосток: Дальнаука, 2001. 400 с.

Гуков Г.В. Лиственницы и лиственничные леса российского Дальнего Востока. Владивосток: ГТС ДВО РАН, 2009. 350 с.

Гурьев А.Д. Берёза Шмидта. М.: Наука, 1980. 114 с.

Денисов Н.И. Деревянистые лианы российского Дальнего Востока. Владивосток: Дальнаука, 2003. 348 с.

Денисов Н.И., Петухова И.П., Пшенникова Л.М., Прилуцкий А.Н. Декоративные деревья, кустарники и лианы в Приморье. Владивосток: ДВО РАН, 2005. 211 с.

Дикорастущие кормовые злаки советского Дальнего Востока / Под ред. С.С. Харкевича. М.: Наука, 1982. 240 с.

Журавков А.Ф. Декоративные особенности деревьев, кустарников и лиан Приморья и Приамурья. Владивосток, 1968. 167 с.

Журавлев Ю.Н., Коляда А.С. Araliaceae: женьшень и другие. Владивосток: Дальнаука, 1996. 280 c.

Заиконникова Т.И. Дейции - декоративные кустарники. Монография рода Deutzia Thunb. М.; Л.: Наука, 1966. 140 с.

Измоденов А.Г. Силедия. Начало учения. Лесные соки и ягоды. Хабаровск: Кн. издво, 2001. 368 с.

Кожевников А.Е. Сытевые (семейство Суреraceae Juss.) Дальнего Востока России (современный таксономический состав и основные закономерности его формирования). Владивосток: Дальнаука, 2001. 275 с.

Кожевников А.Е., Кожевникова 3.В. Таксономический состав и особенности природной флоры Приморского края // Комаровские чтения. 2014. Вып. LXII.C. 7-62. 
Колдаева М.Н., Нестерова С.В., Пшенникова Л.М. 100 мгновений весны. Владивосток: Издательство Морского государственного университета, 2013. 254 с.

Коляда А.С. Руководство к определению древесных растений Приморского края в облиственном состоянии: Учебное пособие. Уссурийск: Изд-во УГПИ, 2008. 92 с.

Коляда А.С. Древесные растения Приморья в зимний период. Определитель: Учебное пособие. Владивосток: Центр «Амурский тигр», 2020. 112 с.

Коляда А.С., Глущенко Ю.Н., Белов А.Н., Быковская Н.В., Литвинова Е.А., Репш Н.В., Маркова Т.О. Происхождение русских названий растений Дальнего Востока: Учебное пособие. Владивосток: Дальневосточный федеральный университет, 2017. 130 с.

Коляда А.С., Кадис И.Н. Сосудистые растения Дальнего Востока России. Русскоанглийский словарь. Уссурийск: Изд-во УГПИ, 2011. 160 с.

Коляда А.С., Храпко О.В., Коляда Н.А. О чем говорят названия растений? Этимологический словарь русских названий сосудистых растений российского Дальнего Востока. Владивосток: БСИ ДВО РАН, 2009. 215 с.

Коляда Н.А. Североамериканские древесные растения на юге Дальнего Востока России. Владивосток: Дальнаука, 2007. 166 с.

Комаров В.Л., Клобукова-Алисова Е.Н. Малый определитель растений Дальневосточного края. Владивосток, 1925. 516 с.

Комаров В.Л., Клобукова-Алисова Е.Н. Определитель растений Дальневосточного края. Л.: АН СССР, 1931. Т. 1. 622 с.; 1932. Т. 2. С. 623-1175.

Комарова Т.А. Семенное возобновление растений на свежих гарях (леса Южного Сихотэ-Алиня). Владивосток: ДВНЦ АН СССР, 1986. 224 с.

Комарова Т.А., Орехова Т.П., Приходько О.Ю. Кустарники и деревянистые лианы Южного Сихотэ-Алиня: экологическая толерантность, развитие и продуктивность. Владивосток: Дальнаука, 2012. 203 с.

Коркина В.Н. Семейство ивовых (Salicaceae) в Приморском крае // Комаровские чтения. Владивосток, 1975. Вып. 23. С. 3-38.

Красная книга Приморского края. Растения. Владивосток: АВК «Апельсин», 2008. 688 с.

Куренцова Г.Э. Реликтовые растения Приморья. Л.: Наука, 1968. 72 с.

Любарский Л.В., Соловьев К.П., Трегубов Г.А., Цымек А.А. Ясень маньчжурский. Хабаровск: Кн. изд-во, 1961. 128 с.

Манько Ю.И., Ельаянская. Л.: Наука, 1987. 280 с.

Максимов О.Б., Кулеш Н.И., Горовой П.Г. Полифенолы дальневосточных растений. Владивосток: Дальнаука, 2002. 332 с.

Миронова Л.Н. Ирисы Приморского края (распространение, антэкология, развитие в культуре, перспективы использования и задачи охраны генофонда). Автореф. дис. ... канд. биол. наук. Владивосток, 1982.

Небайкин В.Д. Зелёные спутники дачника. Хабаровск: Кн. изд-во, 1991. 22 с.

Недолужко В.А. Ключ для определения дальневосточных видов жимолости // Бюл. Гл. ботан. сада АН СССР. 1982. Вып. 125. С. 32-34.

Недолужко В.А. Конспект дендрофлоры российского Дальнего Востока. Владивосток: Дальнаука, 1995. 208 с.

Нечаев А.П. Зелёные стрелы. Рассказы амурского ботаника. Хабаровск: Издательский дом «Приамурские ведомости», 2009. 256 с.

Нечаев В.А. Птицы - потребители и распространители плодов и семян древесных растений в Приморском крае // Бюл. МОИП. Отд. биол. 2001. Т. 106. Вып. 2. С. 14-21. 
Нечаев В.А., Наконечная О.В. Строение плодов, семян и способы диссеминации двух видов рода Aristolochia L. в Приморском крае // Известия РАН. Серия биологическая. 2009. № 4. С. 468-472.

Нечаева Т.И. Определитель сорных растений Приморского края. Владивосток: Изд-во ДВГУ, 1993. 92 с.

Нечаева Т.И. Адвентивные растения Приморского края. Владивосток, 1998. 264 с.

Нечаева Т.И. Школьный определитель растений Приморского края. Владивосток, 2000. 222 c.

Овсянников В.Ф. Лиственные породы. Пособие для учащихся и лесных специалистов. Владивосток: ОГИЗ-Далькрайуправление, 1931. 376 с.

Орехова Т.П. Семена деревянистых растений (морфология, анатомия, биохимия и хранение). Владивосток: Дальнаука, 2005. 161 с.

Панков Ю.А. Дикорастущие розы (шиповники) Дальнего Востока и их использование. Владивосток, 1987. 128 с.

Паршина Е.А.Ядовитые растения Дальнего Востока. Хабаровск: Изд-во Хабаровского государственного медицинского института, 1995. 33 с.

Петухова И.П. Рододендроны на юге Приморья. Владивосток: БСИ ДВО РАН, 2006. 131 с.

Прогунков В.В. Ресурсы медоносных растений юга Дальнего Востока. Владивосток: Изд-во ДВГУ, 1989. 229 с.

Пшенникова Л.М. Водные растения российского Дальнего Востока. Владивосток: Дальнаука, 2005. 106 с.

Рыбакова В.В., Коляда А.С. Краеведческий материал для изучения темы «Видоизменения побегов» в курсе ботаники общеобразовательной школы в Приморском крае // Животный и растительный мир Дальнего Востока. Выпуск № 34. Материалы региональной научной конференции «Животный и растительный мир Дальнего Востока» (г. Уссурийск, Школа педагогики ДВФУ, 25 ноября 2020 г.). Владивосток : Дальневосточный федеральный университет, 2020. С. 20-38. Режим доступа: http://uss.dvfu.ru/epublications/2020/zhivotny_i_rastitelny_mir_dv_v34_2020.pdf.

Сосудистые растения советского Дальнего Востока / под ред. С.С. Харкевича. Л.: Наука, 1985-1989. ТТ. 1-4. СПб.: Наука, 1991-1996. ТТ. 5-8.

Стародубцев В.Н. Ветреницы: систематика и эволюция. Л.: Наука, 1990. 200 с.

Старченко B.M. Бурачниковые (Boraginaceae G. Don) советского Дальнего Востока. Владивосток, 1985. 107 с.

Строгий А.А. Деревья и кустарники Дальнего Востока. Их лесоводственные свойства, использование и техническое применение. Москва-Хабаровск: Объединение государственных и книжно-журнальных издательств: Дальневост. краевое изд-во, 1934. 236 с.

Супрунов Н.И., Горовой П.Г., Панков Ю.А. Эфирно-масличные растения Дальнего Востока. Новосибирск: Наука, 1972. 188 с.

Титлянов А.А. Актинидии и лимонник. Владивосток: Дальневост. кн. изд-во, 1969. 175 с.

Урусов В.М. География хвойных Дальнего Востока. Владивосток: Дальнаука, 1995. 250 с.

Урусов В.М. Сосны и сосняки Дальнего Востока. Владивосток: ВГУЭИС, 1999. 385 с.

Урусов В.М., Лобанова И.И. Деревья, кустарники и лианы Приморского края. Владивосток: ТИГ ДВО РАН, 2018. 475 с.

Урусов В.М., Лобанова И.И., Варченко Л.И. Хвойные деревья и кустарники российского Дальнего Востока: география и экология (биология, изменчивость, экология, география голосеменных). Владивосток: Дальнаука, 2004. 111 с. 
Урусов В.М., Лобанова И.И., Варченко Л.И. Хвойные российского Дальнего Востока - ценные объекты изучения, охраны, разведения и использования Владивосток: Дальнаука, 2007. $438 \mathrm{c}$.

Усенко Н.В. Деревья, кустарники и лианы Дальнего Востока: справочная книга. Хабаровск: Издательский дом «Приамурские ведомости», 2009. 272 с.

Флора Российского Дальнего Востока. Дополнения и изменения к изданию «Сосудистые растения советского Дальнего Востока». Т. 1-8 (1985-1996). Владивосток: Дальнаука, 2006. $456 \mathrm{c}$.

Фролов В.Д., Коляда А.С. Определитель травянистых весенних растений Приморского края (пособие для учителей биологии растений средней и высшей школы). Уссурийск: Изд-во УГПИ, 2000. 126 с.

Храпко О.В., Касинцева М.В., Денисов Н.И., Калинкина В.А., Колдаева М.Н., Коляда А.С., Москалюк Т.А., Небайкни В.Д. Флора Приморского края: Учебное пособие. Уссурийск: Изд-во ДВФУ (филиал в г. Уссурийске), 2012. 140 с.

Цымек А.А. Лиственные породы Дальнего Востока, пути их использования и воспроизводства. Хабаровск: Кн. изд-во, 1956. 328 с.

Шретер А.И. Лекарственная флора советского Дальнего Востока. М.: Медицина, 1975. $326 \mathrm{c}$.

Kozhevnikov A.E., Kozhevnikova Z.V., Myounghai Kwak, Byoung Yoon Lee. Illustrated flora of the Primorsky Territory (Russian Far East). Incheon: National Institute of Biological Resources, 2019. $1126 \mathrm{p}$. 
Коляда Александр Степанович - канд. биол. наук, доцент, доцент. Приморская государственная сельскохозяйственная академия. 692510, Приморский край, г. Уссурийск, пр-т Блюхера 44. E-mail: a.s.pinus@mail.ru;

Ключников Денис Александрович - канд. биол. наук. Дальневосточный федеральный университет. Филиал в г. Уссурийске (Школа педагогики). 692500, Приморский край, г. Уссурийск, ул. Некрасова, 35. E-mail: klyuchnikov_da@mail.ru;

Белов Александр Никитович - канд. с.-х. наук, доцент, доцент. Дальневосточный федеральный университет. Филиал в г. Уссурийске (Школа педагогики). 692500, Приморский край, г. Уссурийск, ул. Некрасова, 35. E-mail: belov_an13@mail.ru; 